\title{
303-K Storage Facility Closure Plan
}

\author{
Date Published \\ December 1993
}

\section{DISCLAIMER}

This report was prepared as an account of work sponsored by an agency of the United States Government. Neither the United States Government nor any agency thereof, nor any of their employees, makes any warranty, express or implied, or assumes any legal liability or responsibility for the accuracy, completeness, or usefulness of any information, apparatus, product, or process disclosed, or represents that its use would not infringe privately owned rights. Reference herein to any specific commercial product, process, or service by trade name, trademark, manufacturer, or otherwise does not necessarily constitute or imply its endorsement, recommendation, or favoring by the United States Government or any agency thereof. The views and opinions of authors expressed herein do not necessarily state or reflect those of the United States Government or any agency thereof.

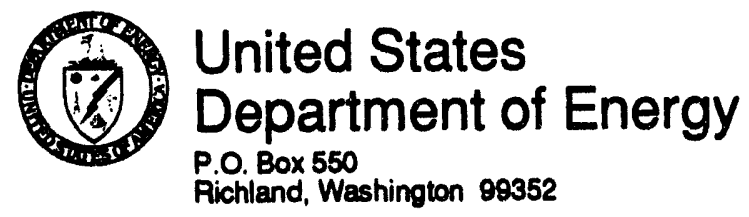


TRADEMARK DISCLAIMER

Relerence herein to any specific commercial product, process, or service by trade name, trademark, manulacturer, or otherwise, does not necessarily constitute or imply its endorsement, recommendation, or favoring by the United States Government or any agency thereof or its contractors or subcontractors.

This report has been reproduced from the best available copy. Available in paper copy and microfiche.

Available to the U.S. Department of Energy and its contraciors from

Office of Scientific and Technical Information

P.0. Box 62

Oak Ridge, TN 37831

(615) $576-8401$

Available to the public from the U.S. Department of Commerce National Technical Information Service

5285 Port Royal Road

Springtield, VA 22161

(703) $487-4650$

Printed in the Unitod States of Amorica

DISCLM.5.CHP (8-91) 
DOE/RL-90-04, Rev. 2

$12 / 15 / 93$

THE 303-K STORAGE FACILITY CLOSURE PLAN

FOREWORD

The Hanford Facility is owned by the U.S. Government and operated by the U.S. Department of Energy, Richland Operations Office. Dangerous waste and mixed waste (containing both radioactive and dangerous components) are produced and managed on the Hanford Facility. The dangerous waste is regulated in accordance with the Resource Conservation and Recovery Act of 1976 and the State of Washington Hazardous Waste Management Act of 1976 (as administered through the Washington State Department of Ecology Dangerous Waste Regulations, Washington Administrative Code 173-303). The radioactive component of mixed waste is interpreted by the U.S. Department of Energy to be regulated under the Atomic Energy Act of 1954; the nonradioactive dangerous component of mixed waste is interpreted to be regulated under the Resource Conservation and Recovery Act and Washington Administrative Code 173-303.

For purposes of the Resource Conservation and Recovery Act and the Washington State Department of Ecology Dangerous Waste Regulations, the Hanford Facility is considered to be a single facility. The single dangerous waste permit identification number issued to the Hanford Facility by the U.S. Environmental Protection Agency and the Washington State Department of Ecology is U.S. Environmental Protection Agency/State Identification Number WA7890008967. This identification number encompasses over 60 treatment, storage, and/or disposal units within the Hanford Facility, hereinafter referred to as the Hanford Facility when cited in the context of the Resource Conservation and Recovery Act and the Washington State Department of Ecology Dangerous Waste Regulations.

Westinghouse Hanford Company is a major contractor to the U.S. Department of Energy, Richland Operations Office and serves as co-operator of the 303-K Storage Facility, the treatment and storage unit addressed in this closure plan.

Westinghouse Hanford Company is identified in the permit application as a 'co-operator' and signs in that capacity. Any identification of Westinghouse Hanford Company as an 'operator' el sewhere in this application is not meant to conflict with Westinghouse Hanford Company's designation as a co-operator but rather is based on Westinghouse Hanford Company's contractual status (i.e., as an operations and engineering contractor) for the U.S. Department of Energy. 
DOE/RL-90-04, Rev. 2

$12 / 15 / 93$

$$
\begin{aligned}
& 1 \\
& 2 \\
& 3 \\
& 4 \\
& 5
\end{aligned}
$$

This page intentionally left blank. 
1

2

7

8

9

10

11

12

13

14

15

16

17

18

19

20

21

22

23

24

25

26

27

28

29

30

31

32

33

34

35

36

37

38

39

40

41

42

43

44
CONTENTS

FOREWORD

ACRONYMS AND ABBREVIATIONS

PART A

1.0 INTRODUCTION

2.0 FACILITY DESCRIPTION

3.0 PROCESS INFORMATION

4.0 WASTE CHARACTERISTICS

5.0 GROUNDWATER

6.0 CLOSURE STRATEGY AND PERFORMANCE STANDARDS

7.0 CLOSURE ACTIVITIES

8.0 POSTCLOSURE

9.0 REFERENCES

\section{APPENDICES}

A PHOTOGRAPHS

B RANDOM SAMPLING LOCATIONS

C BILLET FIRE OCCURRENCE REPORT

D MATERIAL SAFETY DATA SHEETS

E PERSONNEL TRAINING

F QUALITY ASSURANCE PROJECT PLAN FOR FACILITY AND SOIL SAMPLING AT THE 303-K RADIOACTIVE MIXED-WASTE STORAGE FACILITY 


$$
\text { DOE/RL-90-04, Rev. } 2
$$

$12 / 15 / 93$

This page intentionally left blank.

$$
\begin{aligned}
& 1 \\
& 2 \\
& 3 \\
& 4 \\
& 5
\end{aligned}
$$

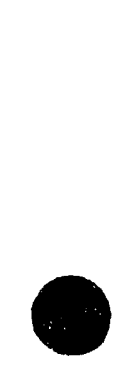

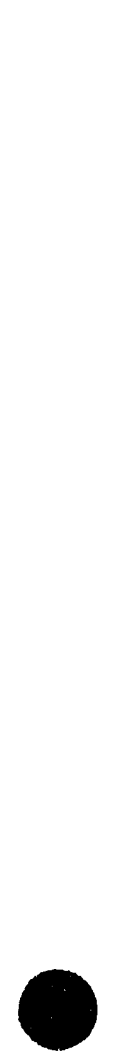

-

vi 


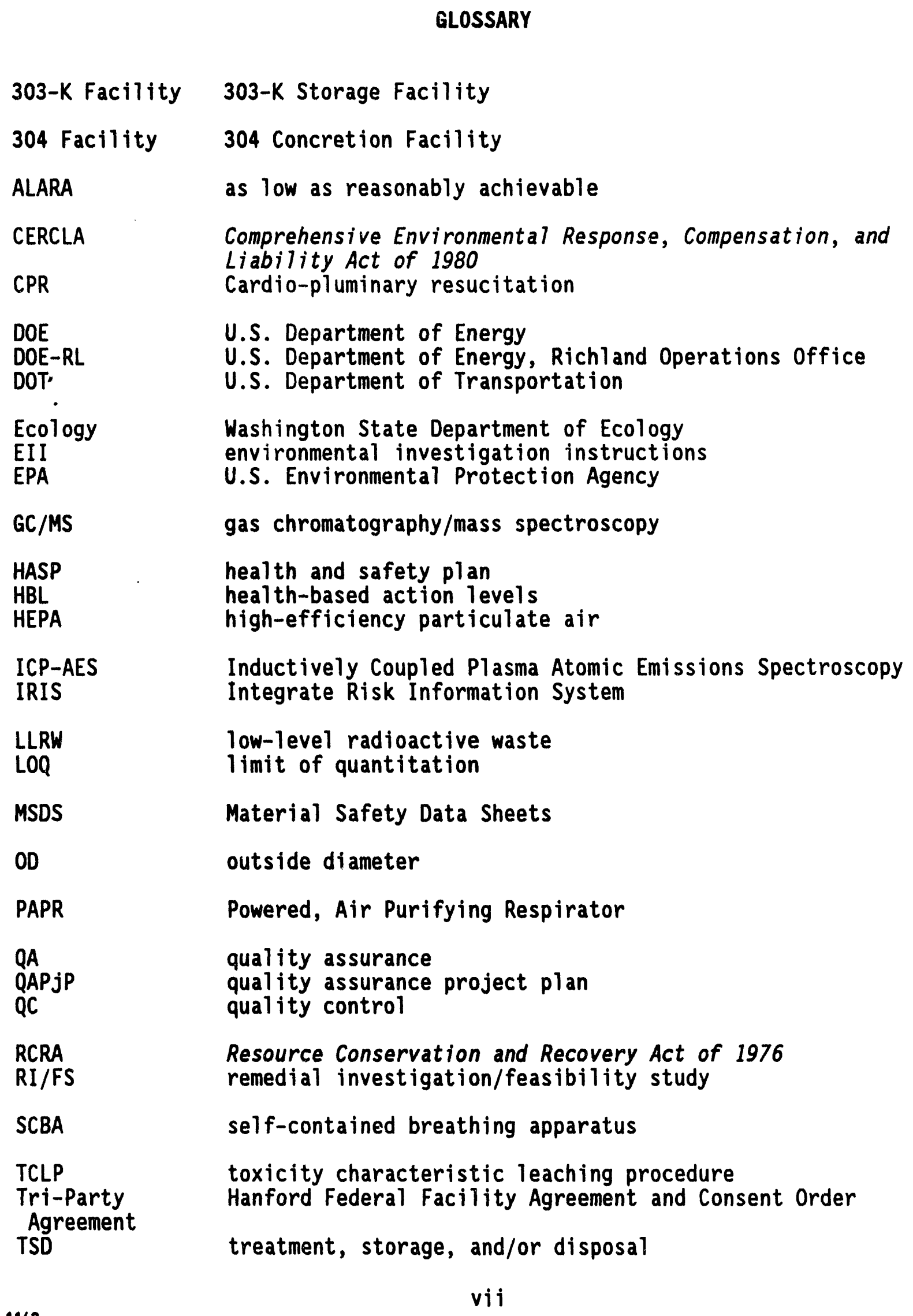


DOE/RL-90-04, Rev. 2

$12 / 15 / 93$

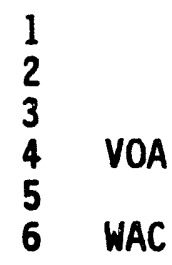

GLOSSARY (continued)

volatile organics analysis

Washington Administrative Code 


\section{DEFINITION OF TERMS}

Action Level. Refers to the chemical concentration levels that will prompt an action. Action level values commonly will be Hanford Facility wide background threshold concentrations, health and environmental based concentrations, toxicity characteristic leaching procedure (TCLP) regulatory levels, and limits of quantitation (LOQ). If action levels are exceeded, actions could include additional decontamination, additional evaluation, building and pad removal, and deferral of soil remediation to the CERCLA remedial action process.

Facility. For purposes of the Resource Conservation and Recovery Act of 1976, the Hanford Facility is considered to be a single facility consisting of a number of waste management units. The term 'facility' also is commonly used in building nomenclature throughout the Hanford Facility (e.g., 303-K Storage Facility). 
DOE/RL-90-04, Rev. 2

$12 / 15 / 93$

1
2
3
4
5
6
7
8
9
10
11
12
13
14
15
16
17
18
19
20
21
22
23
24
25
26
27
28
29
30
31
32
33
34
35
36
37

\section{METRIC CONVERSION CHART}

The following conversion chart is provided to aid in conversion.

Into metric units Out of metric units

\begin{tabular}{|c|c|c|c|c|c|}
\hline If you know & $\begin{array}{c}\text { Multiply } \\
\text { by }\end{array}$ & To get & If you know & $\begin{array}{c}\text { Multiply } \\
\text { by }\end{array}$ & To get \\
\hline \multicolumn{3}{|c|}{ Length } & \multicolumn{3}{|c|}{ Length } \\
\hline inches & 25.40 & millimeters & millimeters & 0.0393 & inches \\
\hline inches & 2.54 & centimeters & centimeters & 0.393 & inches \\
\hline feet & 0.3048 & meters & meters & 3.2808 & feet \\
\hline yards & 0.914 & meters & meters & 1.09 & yards \\
\hline miles & 1.609 & kilometers & kilometers & 0.62 & miles \\
\hline \multicolumn{3}{|c|}{ Area } & \multicolumn{3}{|c|}{ Area } \\
\hline $\begin{array}{l}\text { square } \\
\text { inches }\end{array}$ & 6.4516 & $\begin{array}{l}\text { square } \\
\text { centimeters }\end{array}$ & $\begin{array}{l}\text { square } \\
\text { centimeters }\end{array}$ & 0.155 & $\begin{array}{l}\text { square } \\
\text { inches }\end{array}$ \\
\hline square feet & 0.092 & $\begin{array}{l}\text { square } \\
\text { meters }\end{array}$ & $\begin{array}{l}\text { square } \\
\text { meters }\end{array}$ & 10.7639 & $\begin{array}{l}\text { square } \\
\text { feet }\end{array}$ \\
\hline $\begin{array}{l}\text { square } \\
\text { yards }\end{array}$ & 0.836 & $\begin{array}{l}\text { square } \\
\text { meters }\end{array}$ & $\begin{array}{l}\text { square } \\
\text { meters }\end{array}$ & 1.20 & $\begin{array}{l}\text { square } \\
\text { yards }\end{array}$ \\
\hline $\begin{array}{l}\text { square } \\
\text { miles }\end{array}$ & 2.59 & $\begin{array}{l}\text { square } \\
\text { kilometers }\end{array}$ & $\begin{array}{l}\text { square } \\
\text { kilometers }\end{array}$ & 0.39 & $\begin{array}{l}\text { square } \\
\text { miles }\end{array}$ \\
\hline acres & 0.404 & hectares & hectares & 2.471 & acres \\
\hline \multicolumn{3}{|c|}{ Mass (weight) } & \multicolumn{3}{|c|}{ Mass (weight) } \\
\hline ounces & 28.35 & grams & grams & 0.0352 & ounces \\
\hline pounds & 0.453 & kilograms & kilograms & 2.2046 & pounds \\
\hline short ton & 0.907 & metric ton & metric ton & 1.10 & short ton \\
\hline \multicolumn{3}{|c|}{ Volume } & \multicolumn{3}{|c|}{ Volume } \\
\hline $\begin{array}{l}\text { fluid } \\
\text { ounces }\end{array}$ & 29.57 & millititers & millititers & 0.03 & $\begin{array}{l}\text { fluid } \\
\text { ounres }\end{array}$ \\
\hline quarts & 0.95 & Titers & Titers & 1.057 & quarts \\
\hline gallons & 3.79 & Titers & Titers & 0.26 & gallons \\
\hline cubic feet & 0.03 & $\begin{array}{l}\text { cubic } \\
\text { meters }\end{array}$ & $\begin{array}{l}\text { cubic } \\
\text { meters }\end{array}$ & 35.3147 & cubic feet \\
\hline cubic yards & 0.76 & $\begin{array}{l}\text { cubic } \\
\text { meters }\end{array}$ & $\begin{array}{l}\text { cubic } \\
\text { meters }\end{array}$ & 1.308 & $\begin{array}{l}\text { cubic } \\
\text { yards }\end{array}$ \\
\hline \multicolumn{3}{|c|}{ Temperature } & \multicolumn{3}{|c|}{ Temperature } \\
\hline Fahrenheit & $\begin{array}{l}\text { subtract } \\
32 \text { then } \\
\text { multiply } \\
\text { by } 5 / 9 \text { ths }\end{array}$ & Cetsius & Cetsius & $\begin{array}{l}\text { multiply } \\
\text { by } \\
9 / 5 \text { ths, } \\
\text { then add } \\
32\end{array}$ & Fahrenheit \\
\hline
\end{tabular}

Source: Engineering Unit Conversions, M. R. Lindeburg, PE., Second Ed., 1990, Professional Publications, Inc., Belmont, Cal ifornia. 
PART A

The Part A, Form 1, "Dangerous Waste Permit General Information" was submitted to the Washington State Department of Ecology in May 1988. The Part A, Form 1, consists of three pages.

The original Part A, Form 3, Revision 0, "Dangerous Waste Permit Application" was submitted to Ecology in August 1987. Revision 0 included the treatment design capacity, facility description, dangerous waste codes, and dangerous waste description. Revision 1 of the Part A, Form 3, was prepared to include Westinghouse Hanford Company as co-operator of the 303-K Storage Facility. Revision 2 of the Part A, Form 3, was prepared to add dangerous waste code $\mathrm{DOO2}$ and related estimated annual quantity of dangerous waste for the addition of copper-flurozirconate crystals. Revision 3 of the Part $A$, Form 3, was prepared to add 23 dangerous waste codes and their related estimated annual quantity of dangerous waste.

Revision 4 of the Part A, Form 3, was prepared to add waste codes D029, D035, D037, D039, D040, F002, F005, and WC02. These new waste codes are from the analysis of current waste, the analysis of a previously unknown waste, and from regulatory changes that added new waste codes.

The Part A, Form 3 (Revision 4), included in this closure plan consists of 9 pages, 1 figure, and 1 photograph. 
DOE/RL-90-04, Rev. 2

$12 / 15 / 93$

1
2
3
4
5

This page intentionally left blank. 
Please print or typo in the unshaded areas only

(fill-in areas are spaced for elite typa, i.e., 12 character/inch).

\section{ORM}

DANGEROUS WASTE PERMIT APPLICATION

FOR OFFICIAL USE ONLY

APPLICATION DATE RECEIVED

APPROVED

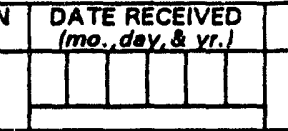

COMMENTS

II. FIRST OR REVISED APPLICATION

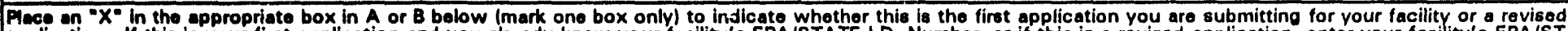

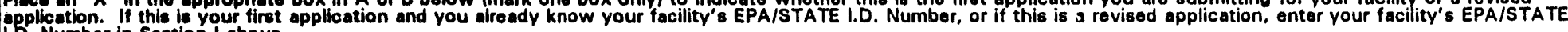
i.b. Number in Section I above.

A. FIRST APPLICATION (place an " $X$ " below and provide the appropriato data)

$\square$ 1. EXISTING FACILITY ISeo instructions for definition of "existing" facility.

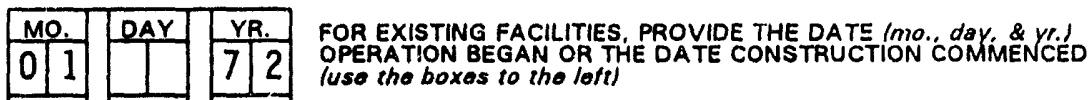

\section{B. REVISED APPLICATION (ploce an " $X$ "bolow and complote Section l abovo)}

DD 1. FACILITY HAS AN INTERIM STATUS PERMIT
2. NEW FACILITY (Complete item below)

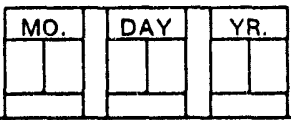

FOR NEW FACILITIES.

(mo. daY, \& yr) OPERA.

TION QDAY, \& Yr) OPER

III. PROCESSES - CODES AND CAPACITIES

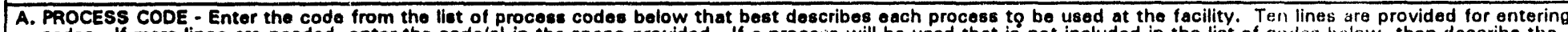
codes. If more lines are needed, onter the code(s) in the space provided. If a process will be used that is not included in the list of cudes below, then describe the process (including its design capacity) in the space provided on the (Section $111-\mathrm{C}$ ).

B. PROCESS DESIGN CAPACITY - For each code entered in column A onter the capacity of the process.

1. AMOUNT - Enter the amount.

2. UNIT OF MEASURE - For each amount entered in column B(1), enter the code from the list of unit measure codes below that describes the unit of measure used. Only the unite of measure that are listed below should be used.

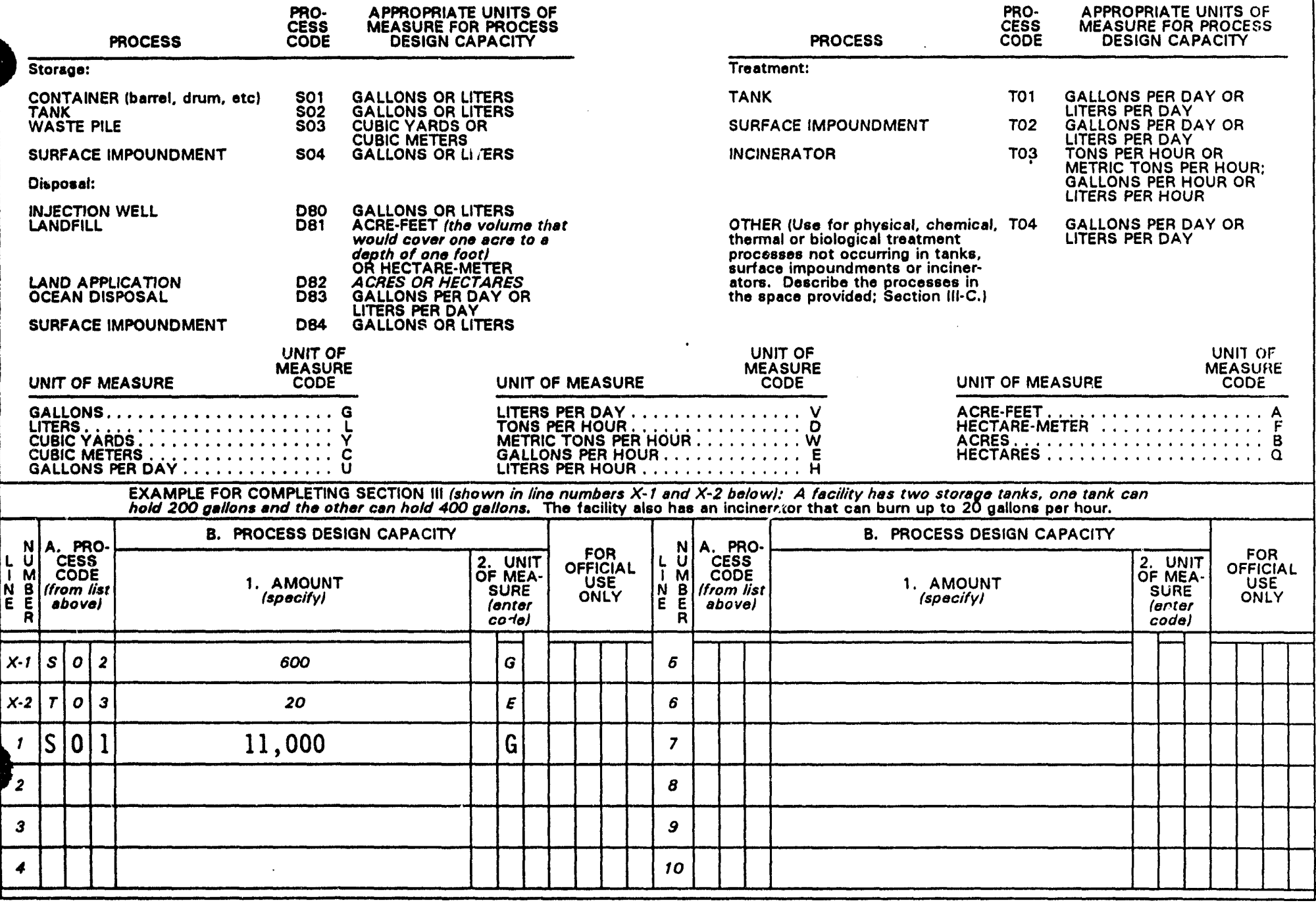

ECL30-300- ECY 030-31 Form 3 Rov. $2 / 84$ 
Continued from the front.

PROCESSES (continued)

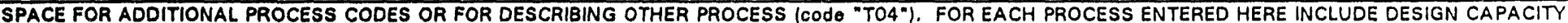

$\underline{\text { SO1 }}$

The 303-K Storage Facility is used for the storage of mixed waste in Department of

Transportation-specification containers. Both liquid and solid waste is stored in the 303-K Storage Facility. The liquid waste is stored on a 610 square foot (57 square meter) pad within the building. The building provides secondary containment for the contents of the containers. The solid waste is stored outside the building on a 4,590 square foot (426 square meter) asphalt, concrete, and gravel pad. The storage area is surrounded by a chain link fence. Approximately 200 55-gailon (208-liter) containers (or more smallersized containers) can be stored at the 303-K Storage Facility.

IV. DESCRIPTION OF DANGEROUS WASTES

A. DANGEROUS WASTE NUMBER - Entor the four digit number from Chapter 173-303 WAC for each listed dangerous waste you will handle. If you hanidle dangerous wastes which are not listed in Chapter 173-303 WAC, onter the four digit number(s) that describes the characteristics and/or the toxic contaminants of those dangerous wastes.

B. ESTIMATED ANNUAL QUANTITY - For each listed waste entered in column A estimate the quantity of that waste that will be handled on an annual basis. For each characteristic or toxic contaminant entered in column $A$ estimate the total annual quantity of all the non-listed waste(s) that will be handled which possese that characteristic or contaminant.

C. UNIT OF MEASURE - For each quantity entered in column B enter the unit of measure code. Units of measure which must be used and the appropriate codes are:

$\frac{\text { ENGLISH UNIT OF MEASURE }}{\text { POUNDS } \ldots \ldots \ldots \ldots \ldots \ldots \ldots \ldots \ldots \text { T }}$

$\frac{\text { METRIC UNIT OF MEASURE }}{\text { KILOGRAMS } \ldots \ldots \ldots \ldots \ldots \ldots \ldots \ldots \ldots}$

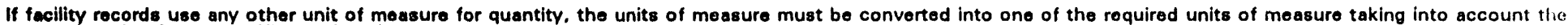
appropriate density or specific gravity of the waste.

D. PROCESSES

1. PROCESS CODES:

For listed dangerous waste: For each listed dangerous waste entered in column A select the code(s) from the list of process codes contained in Section III to indicate how the waste will be stored, troated, andior disposed of at the facility.

For non-listed dangerous wastes: For each characteristic or toxic contaminant entered in Column A, select the code(s) from the list of process codes contained in Section ill to indicate all the procesese that will be used to store, treat, and/or dispose of all the non-listed dangerous wastes that possess that characteristic or

Note: Four spaces are provided for entering process codes. If more are needed: (1) Enter the first three as described above; (2) Enter "O0O" it the extreme right box of trem IV-D(1): and (3) Enter in the space provided on page 4, the line number and the additional code(s).

2. PROCEss DEscription: If a code is not listed for a procese that will be used, describe the process in the space provided on the form.

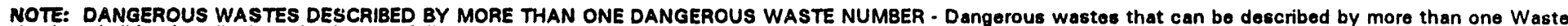
Number shall be described on the form as followe:

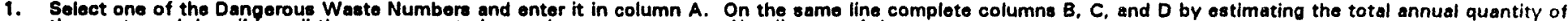
the waste and describing all the processes to be used to treat, store, and/or dispose of the waste.

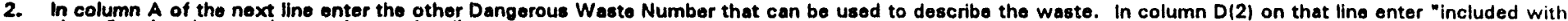
above" and make no other entries on that line.

3. Repeat step 2 for each other Dangerous Waste Number that can be used to describe the dangerous waste.

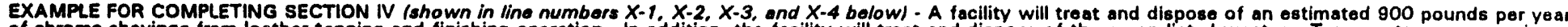

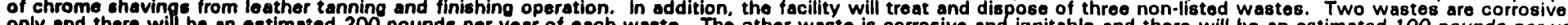
Win estimated 100 pounds per year

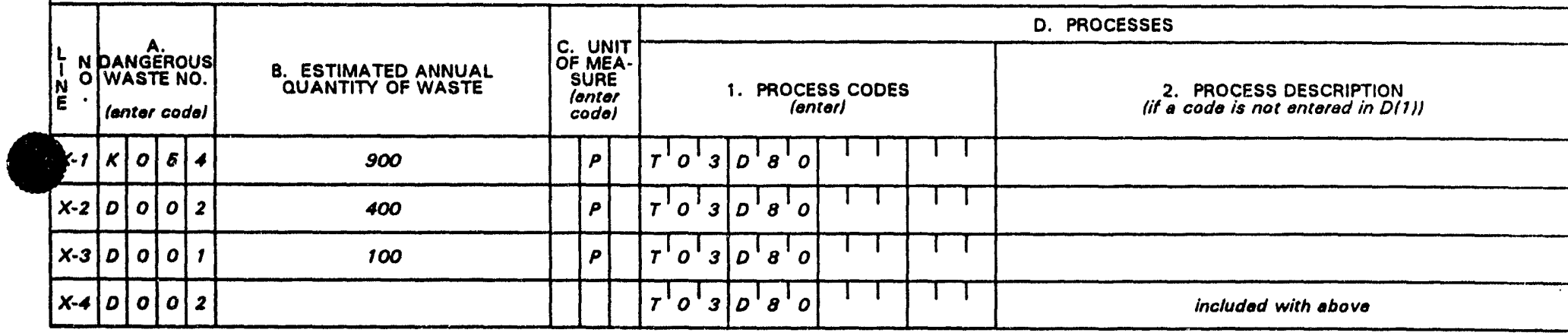

ECL3O - 271 - ECY 030-31 Form 3 
Continued from page 2.

O

D. NUMBER lonterad from paga 11

\begin{tabular}{|l|l|l|l|l|l|l|l|l|l|l|l|}
\hline W & $A$ & 7 & 8 & 9 & 0 & 0 & 0 & 8 & 9 & 6 & 7 \\
\hline
\end{tabular}

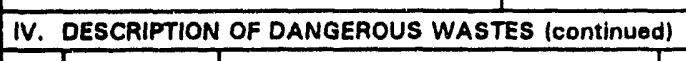

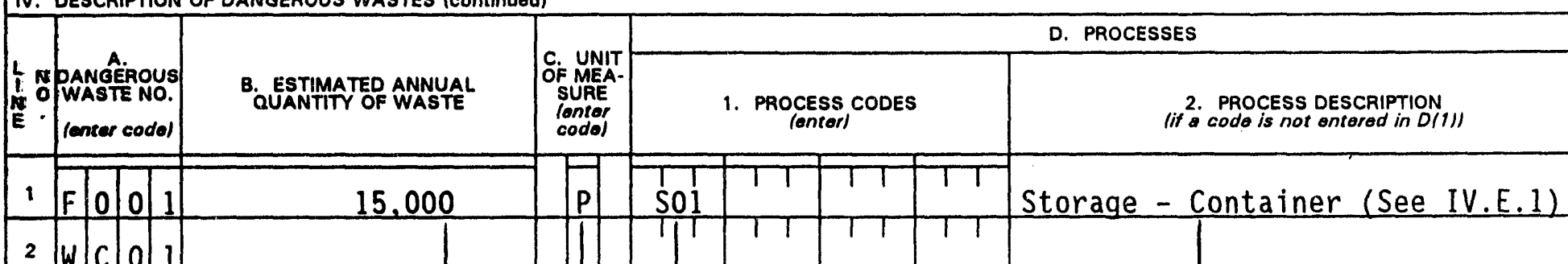

2 W

3 W

4 W

$\begin{array}{lllllll}5 & 0 & 0 & 0 & 1\end{array}$

- $F \quad 00003$

\begin{tabular}{llllll}
7 & $W$ & $T$ & 0 & 2 \\
\hline
\end{tabular}

\begin{tabular}{llllll}
8 & $F$ & 0 & 0 & 2 \\
\hline
\end{tabular}

- F 100005

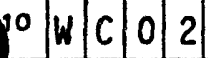

11000000

120000006

\begin{tabular}{l|l|l|l|l|l|l|l|l|l}
13 & 0 & 0 & 2 & 9
\end{tabular}

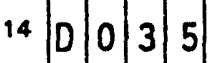

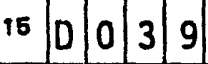

\begin{tabular}{l|l|l|l|l|l}
16 & 0 & 0 & 4 & 0
\end{tabular}

17 W $T$ T 00 : 2

$\begin{array}{llllll}18 & 0 & 0 & 0 & 7\end{array}$

$\begin{array}{lllllll}19 & W & T & 0 & 1\end{array}$

15,000

$\prod^{1}$

4 \begin{tabular}{ll|l|l|l|}
1 & 1 & 1 & 1 & 11 \\
\hline & 1 & 1 & 1 & 1
\end{tabular}

\begin{tabular}{ll|l|l|l|l|}
11 & 1 & 1 & 1 & 1 & 1
\end{tabular}

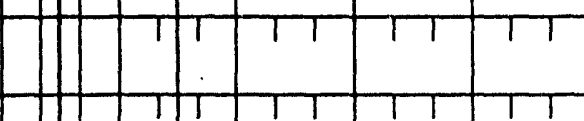

$20\left[\begin{array}{llll}D & 0 & 0 & 1\end{array}\right.$

210000005

22000000

$\begin{array}{lllllll}23 & D & 0 & 0 & 2\end{array}$

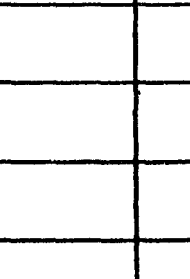

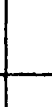


Continued from page 2 .

NOTE: Photocopy this page before completing if you have more than 26 wastes to list.

P. NUMBER lontored from pago II

\begin{tabular}{|l|l|l|l|l|l|l|l|l|l|l|l|}
\hline W & $A$ & 7 & 8 & 9 & 0 & 0 & 0 & 8 & 9 & 6 & 7 \\
\hline
\end{tabular}

IV. DESCRIPTION OF DANGEROUS WASTES (continued)

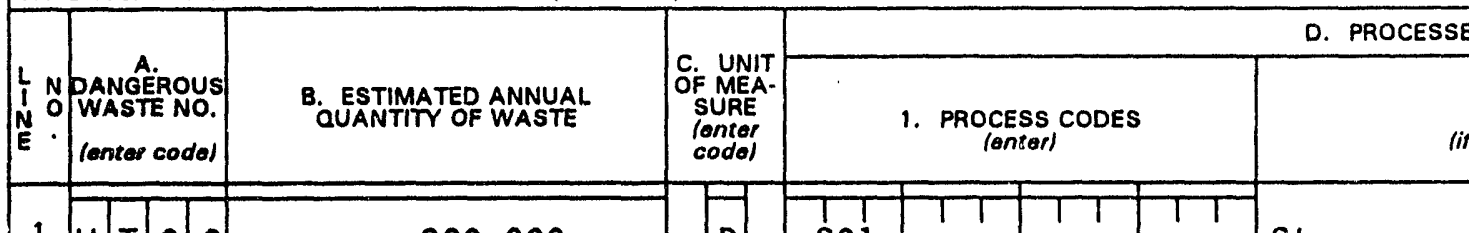

2. PROCESS DESCRIPTION (if a code is not antered in D(1)"

\begin{tabular}{llllll}
1 & $\mathrm{~W}$ & $\mathrm{~T}$ & 0 & 2 \\
\hline
\end{tabular}

300,000

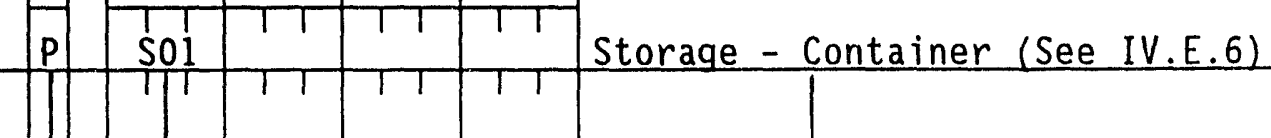

$\begin{array}{llllll}3 & D & 0 & 0 & 4\end{array}$

$\begin{array}{llllll}4 & D & 0 & 0 & 5\end{array}$

5 D

$6 \begin{array}{lllll}6 & 0 & 0 & 0 & 7\end{array}$

$\begin{array}{llllll}7 & 0 & 0 & 0 & 9\end{array}$

\begin{tabular}{llllll}
8 & 0 & 0 & 1 & 1 \\
\hline
\end{tabular}

$\begin{array}{llllll}9 & \mathrm{D} & 0 & 0 & 2\end{array}$

$\begin{array}{llll} & 1 & 1 & 1\end{array}$

\begin{tabular}{l|ll|ll|l|l|} 
& & & 1 & 1 & 1 & 1 \\
\hline & 1 & 1 & 1 & 1 & 1 \\
1 & 1 & 1 & 1 & 1 & 1
\end{tabular}

\begin{tabular}{lllll}
0 & 0 & 0 & 0 & 7 \\
\hline
\end{tabular}

11000000

60

\begin{tabular}{l|l|l|l|ll|l}
\hline & 1 & 1 & 1 & 1 & 1 & \\
\hline 1 & 1 & 1 & 1 & 1 & 1 &
\end{tabular}

\begin{tabular}{l|llll|}
12 & $D$ & 0 & 0 & 4 \\
\hline
\end{tabular}

130000007

\begin{tabular}{llllll}
14 & 0 & 0 & 1 & 1 \\
\hline
\end{tabular}

\begin{tabular}{l|l|l|l|l}
16 & $W$ & $P$ & 0 & 2 \\
\hline
\end{tabular}

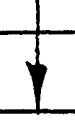

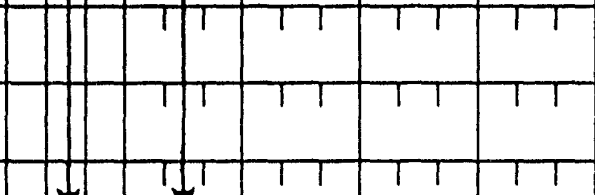

1,500

\begin{tabular}{llllll}
16 & $D$ & 0 & 3 & 7 \\
\hline
\end{tabular}

17

18

19

20

21

22

23

1,500

Sol

included with above

Storage - Container (See IV.E.7)

included with above

Storage - Container (See IV.E.8)
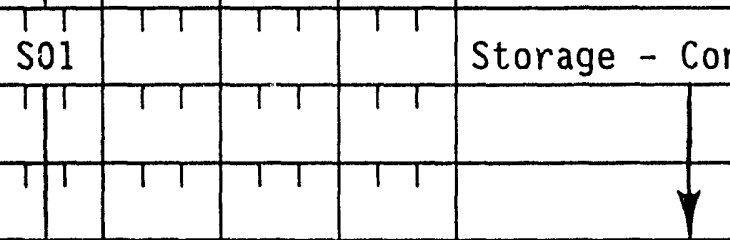

included with above

Storage - Container (See IV.E.9)

Storage - Container (See IV.E.10)

44

P SOI

\begin{tabular}{l|l|l|l|l|l|}
\hline 1 & 1 & 1 & 1 & 1 \\
\hline 1 & 1 & 1 & 1 & 1 & 1
\end{tabular}


Continued from the tront.

DESCRIPTION OF DANGEROUS WASTES (continued)

USE THIS SPACE TO LIST ADDITIONAL PROCESS CODES FROM SECTION DI1) ON PAGE 3.

\section{SEE FOLLOWING PAGE}

T. FACILITY DRAWING

All existing lacilitios must include in the spece provided on page 5 a scale drawing of the facility (soe instructions for more dotaill.

VI. PHOTOGRAPHS

All exiating facilitios must include pholographe (oorio/ or ground-levell that clearly dolineate all existing structures: exlsting storage, treatment and disposal areas; and

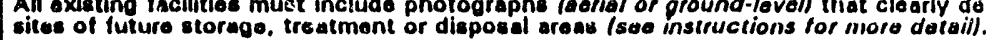

VII. FACILITY GEOGRAPHIC LOCATION This information is provided on the attached drawings and photos.

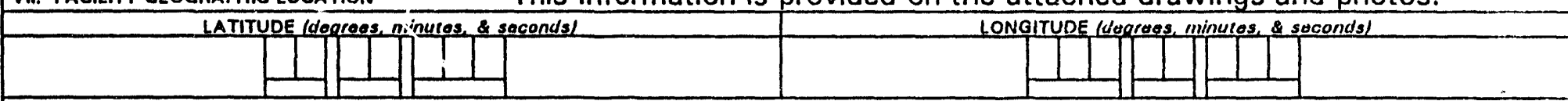

\section{FACILITY OWNER}

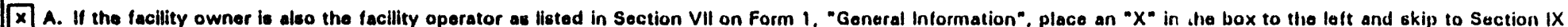
bolow.

8. If the fecillty owner is not the facility operator as listed in Section VII on Form 1, complete the following items:

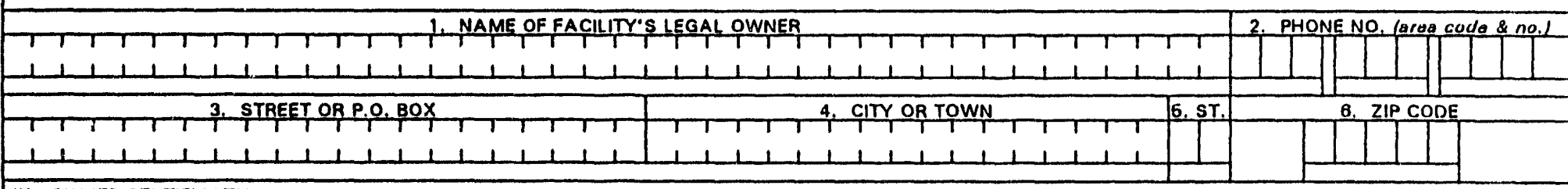

IX. OWNER CERTIFICATION

I cerrify under penalty of law that I hove parsonally axamined and am faniliar with tho information submitted in this and all attached documants, and that based un

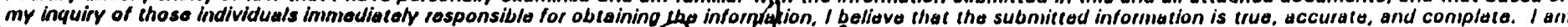

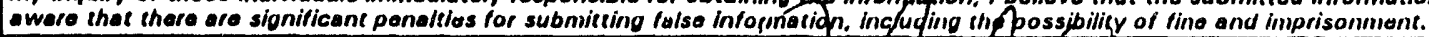

\begin{tabular}{|l|l|l|}
\hline NAME (prine or (Ypol & BIGNATURE \\
\hline
\end{tabular}

John D. Wagoner, Manager

U.S. Department of Energy

Richland Operations office

X. OPERATOR CERTIFICATION

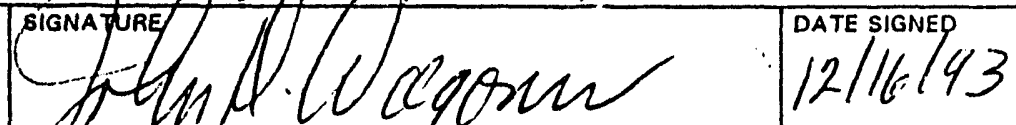

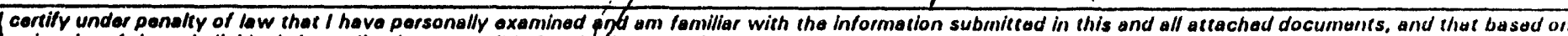
my inquiry of those individuals immediatoly rosponsiblo for oblaining the information. I beliovo that the subrmitted information is true, accurato, and complete. I an eware that there are signilicant ponaltios for submitting falso intormation, including tho possibility of fine and imprisonment.

NAME (print or eypol SIGNATURE

DATE SIGNED

SEE ATTACHMENT

ECL30 - 271 - ECY 030-31 form 3 
Section IV.E. Description of Dangerous Wastes

The 303-K Storage Facility is used for the storage of mixed waste in U.S. Department of Transportation-specification containers. This waste consists of the following:

1. Approximately 15,000 pounds $(6,800$ kilograms) per year of spent solvents [This includes spent degreasing solvents (FO0], WCOl, WPO1, and WTO1) that were occasionally mixed with ethyl acetate (D001, F003, and WT02). This a) so includes spent halogenated and nonhalogenated solvents (F002 and F005) as well a: waste with low concentrations of carcinogenic solvents (WC02). Waste solvents are corrosive (D002) and containe cadmium (D006), 1,1-dichloroethylene (D029), methyl ethyl ketone (D035), tetrachloroethylene (D039), and trichloroethylene (D040)].

2. Approximately 80,000 pounds $(36,300$ kilograms $)$ per year of heat treat salts contaminated with naturally occurring radioactive potassium-40 [The heat treat salts were generated from both beta bath $[40,000$ pounds $(18,200$ kilograms) per year] and quench bath $[40,000$ pounds (18,000 kilograms) per year]. The beta bath salts consist of potassium chloride and sodium chloride (WT02) and chromium (D007). The quench bath salts consist of potassium nitrate, sodium nitrate, sodium nitrite, potassium chloride, and sodium chloride. The quench bath salts are toxic extremely hazardous waste (WTO1) and are ignitable (DOO1) because of the presence of oxidizers (solid nitrates and nitrites). The quench bath salts also contain barium (D005) and cadmium (D006).

3. Approximately 1,700 pounds (770 kilograms) of corrosive (D002) copper fluorozirconate acid crystals from the bottom of the waste acid tanks in the 334-A Building

4. Approximately 5,100 pounds $(2,300$ kilograms) per year of Zircaloy-2 and beryllium/Zircaloy-2 chips and fines before and after concreting the waste in the 304 Building (This material is designated ignitable (D001) because of its pyrophoric properties.)

5. Approximately 5,500 pounds $(2,500$ kilograms $)$ per year of metallic lead (D008)

6. Approximately 300,000 pounds $(136,100$ kilograms) per year of centrifuge and filter press sludge designated as a toxic dangerous waste (WTO2) by the mixture rule and ignitable (DOOI) because of the presence of solid nitrates [The waste may also contain the following ions introduced into the 300 Area Waste Acid Treatment System: arsenic (D004), barium (D005), cadmium (D006), chromium (D007), mercury (D009), and silver (D011)].

7. Approximately 1,500 pounds ( 680 kilograms) per year of corrosive (D002) waste acid absorbed by sedimentary opal clay [This waste also contains chromium (D007)].

8. Approximately 60 pounds (27 kilograms) per year of waste acids contaminated with oil [The waste acids are designated as corrosive (D002) and contain arsenic (D004), chromium (D007), and silver (D011)].

9. Approxima ely 200 pounds (91 kilograms) per year of waste hydraulic oil containing halogenated hydrocarbons (WPO2)

10. Approximately 44 pounds ( 20 kilograms) of a mixed waste that contains pentachlorophenol (D037) 


\section{OPERATOR CERTIFICATION}

I certify under penalty of law that I have personally examined and am familiar with the information submitted in this and all attached documents, and that based on my inquiry of those individuals immediately responsible for obtaining the information, I believe that the submitted information is true, accurate, and complete. I am aware that there are significant penalties for submitting false information, including the possibility of fine and imprisonment.

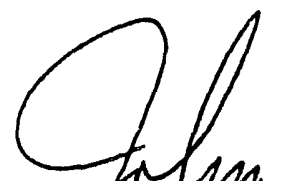

other/Operator

John D. Wagoner, Manager

W.S. Department of Energy

Richland Operations Office

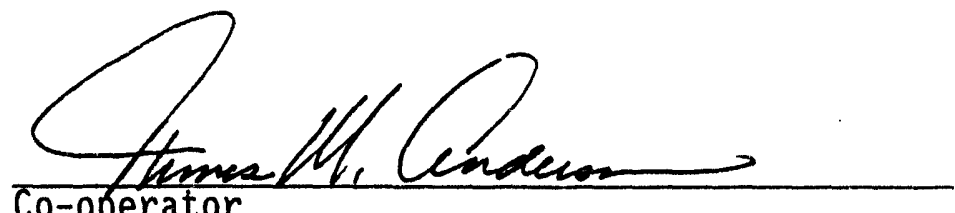

Co-operator

Thomas M. Anderson, President Westinghouse Hanford Company
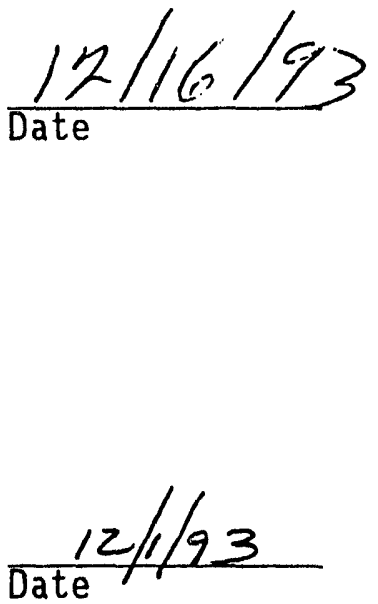


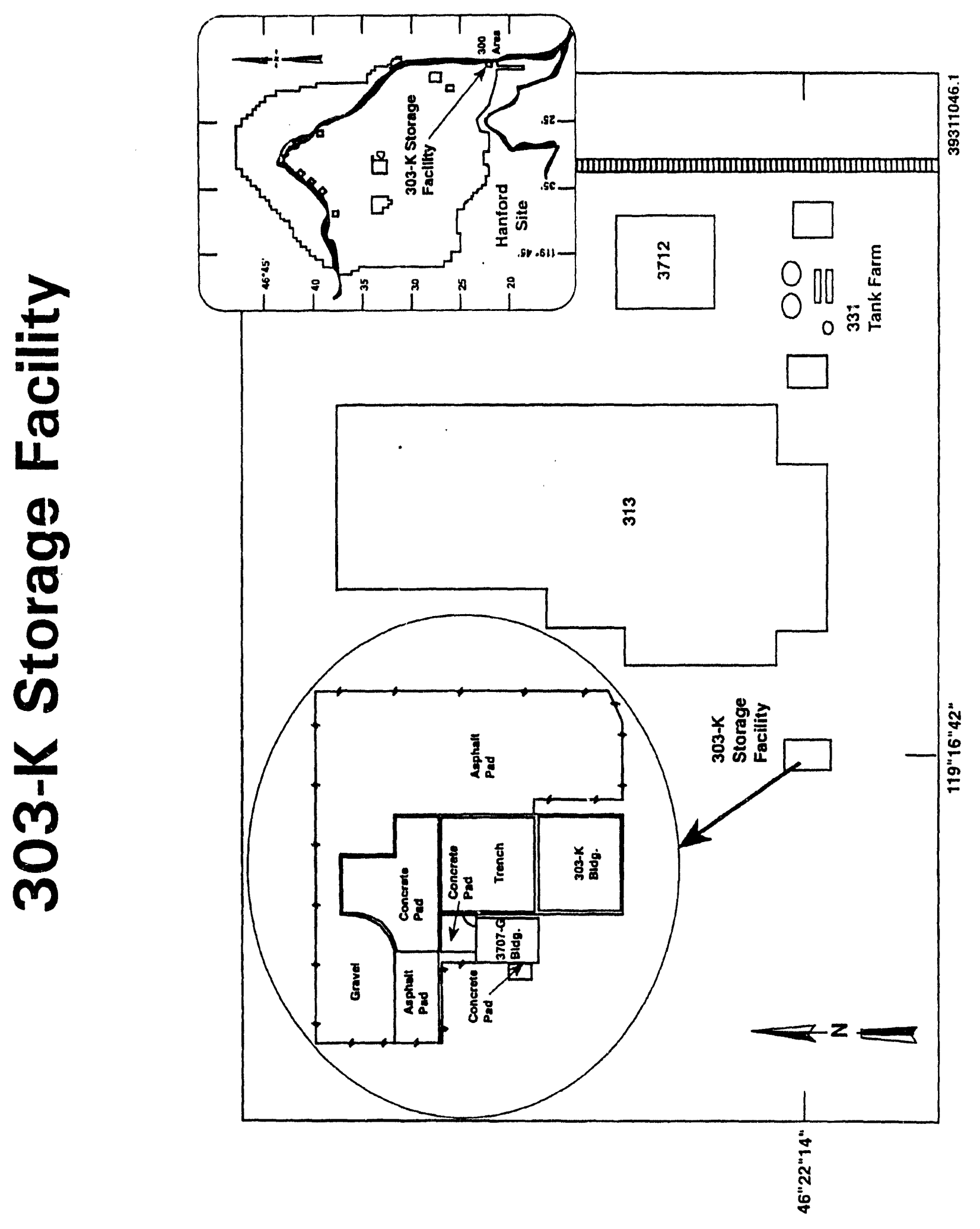




\section{3-K Storage Facility}

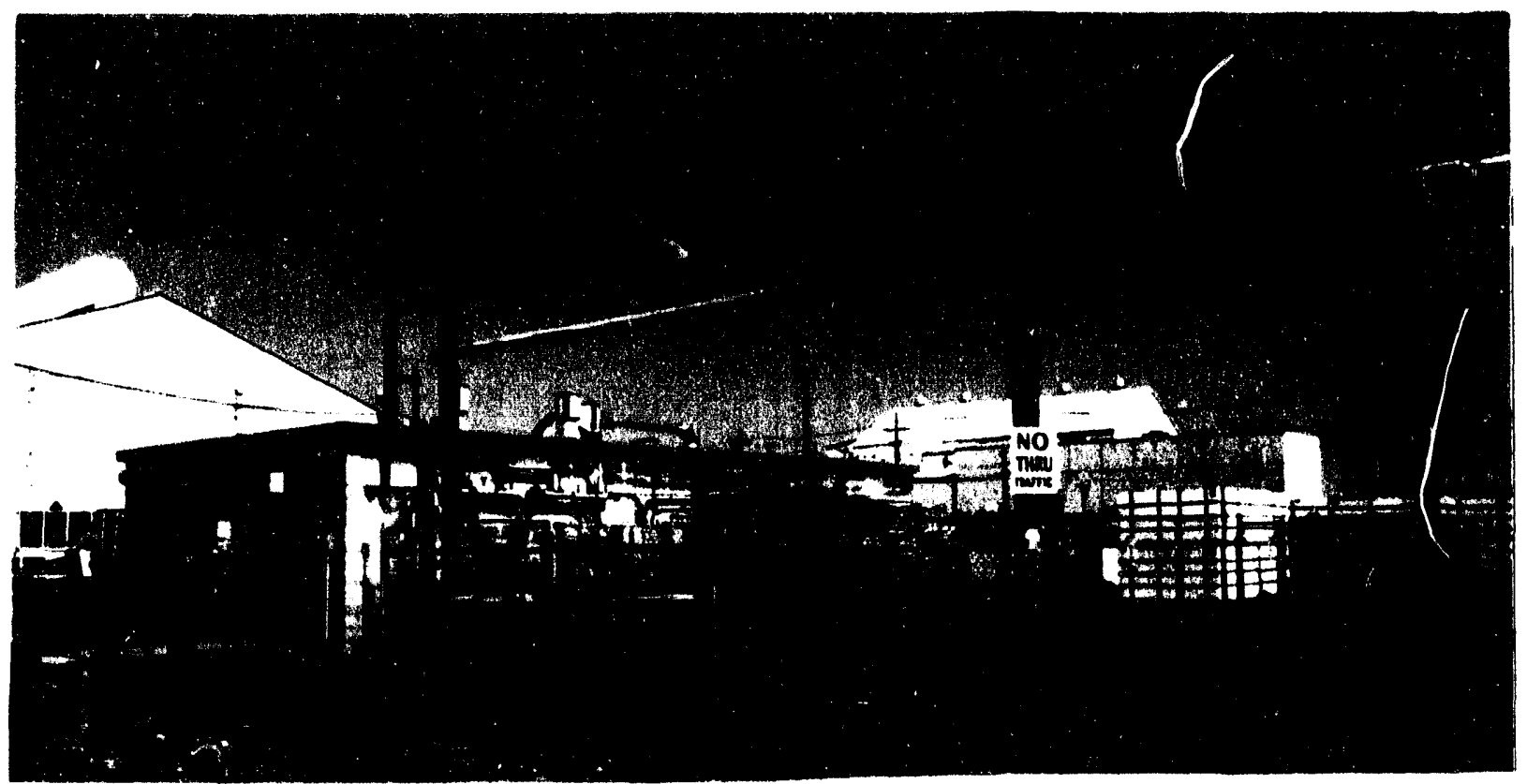

8704479-10CN

(PHOTO TAKEN 1987)

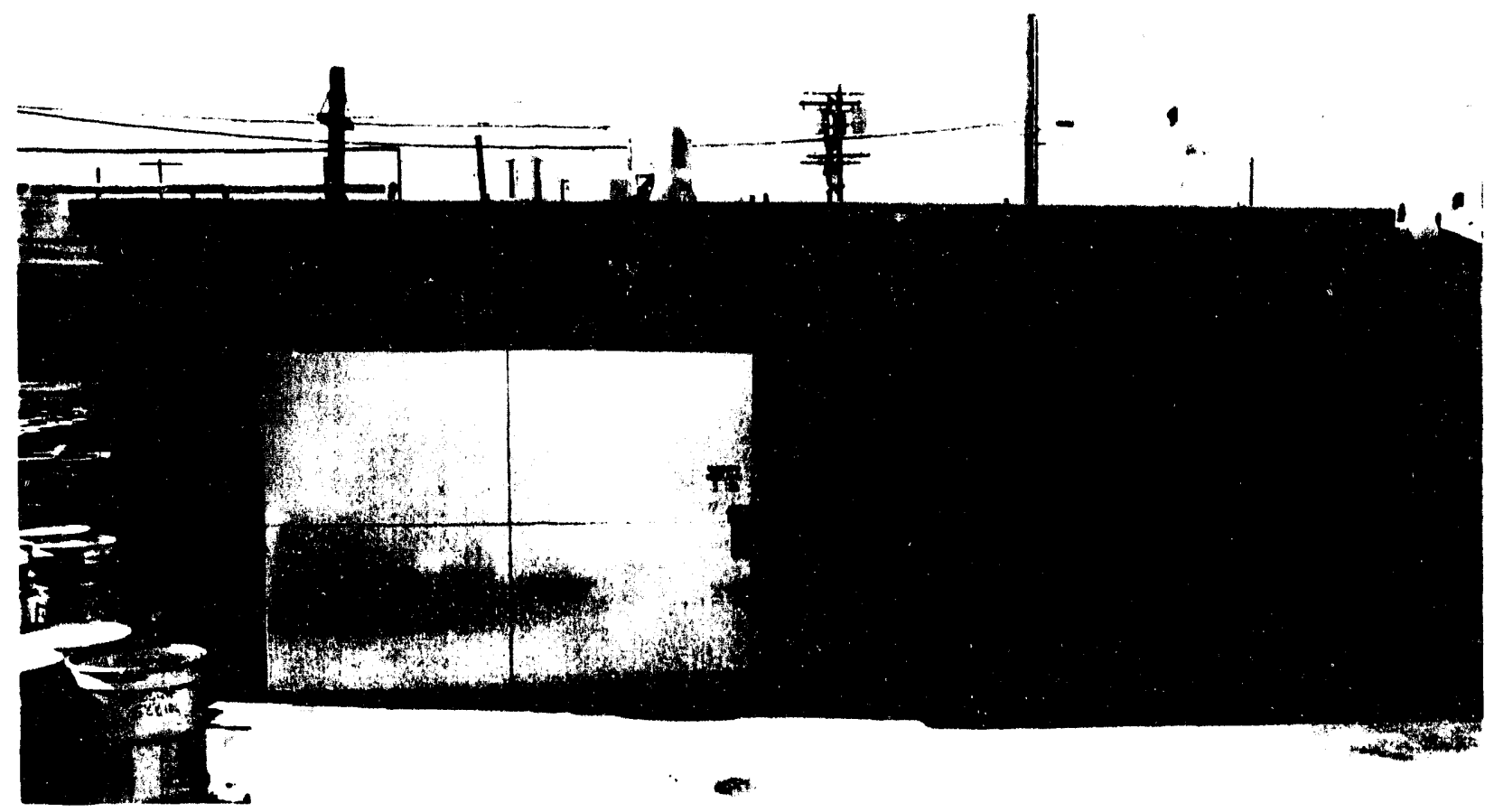




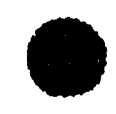

1.0 INTRODUCTION . . . . . . . . . . . . . . . . . . . . 1-1

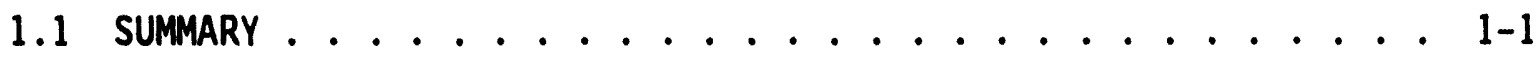

1.2 THE 303-K STORAGE FACILITY . . . . . . . . . . . . . . 1-1

1.2.1 Facility Description ................ 1-2

1.2.2 Process Information ................ 1-2

1.2.3 Waste Characteristics .............. . . 1-2

1.2.4 Groundwater .................... 1-2

1.2.5 Closure Strategy and Performance Standards . . . . . . . 1-2

1.2.6 Closure Activities ................ 1-2

1.2.7 Postclosure . . . . . . . . . . . . . . . 1-2

1.2 .8 References.................... 1-3 
DOE/RL-90-04, Rev. 2

$12 / 15 / 93$

1
2
3
4
5

This page intentionally left blank. 
DOE/RL-90-04, Rev。 2 $12 / 15 / 93$

\subsection{INTRODUCTION}

This chapter provides background information for the 303-K Storage Facility and provides an overview of the contents of the 303-K Storage Facility closure plan.

\subsection{SUMMARY}

Recyclable scrap uranium with zircaloy-2 and copper silicon alloy, uranium-titanium alloy, beryllium/zircaloy-2 alloy, and zircaloy-2 chips and fines were secured in concrete billets (7.5-gallon containers) in the 303-K Storage Facility, located in the 300 Area. The beryllium/zircaloy-2 alloy and zircaloy-2 chips and fines are designated as mixed waste with the characteristic of ignitability. The concretion process reduced the ignitability of the fines and chips for safe storage and shipment. This process has been discontinued and the 303-K Storage Facility is now undergoing closure as defined in the Resource Conservation and Recovery Act (RCRA) of 1976 and the Washington Administrative Code (WAC) Dangerous Waste Regulations, WAC 173-303-040.

This closure plan presents a description of the 303-K Storage Facility, the history of materials and waste managed, and the procedures that will be followed to close the 303-K Storage Facility. The 303-K Storage Facility is located with in the 300-FF-3 (source) and 300-FF-5 (groundwater) operable units, as designated in the Hanford Federal Facility Agreement and Consent Order (Tri-Party Agreement) (Ecology et al. 1992). Contamination in the operable units $300-F F-3$ and $300-F F-5$ is scheduled to be addressed through the Comprehensive Environmental Response, Compensation, and Liability Act (CERCLA) of 1980 remedial action process. Therefore, all soil remedial action at the 304 Facility will be conducted as part of the CERCLA remedial action of operable units $300-F F-3$ and $300-F F-5$.

The 303-K Storage Facility is subject to requirements for the storage and treatment of dangerous waste. The 303-K Storage Facility will be closed pursuant to the requirements of WAC 173-303-610.

\subsection{THE 303-K STORAGE FACILITY} follows.

The 303-K Storage Facility Closure Plan consists of nine chapters as

- Introduction (Chapter 1.0)

- Facility Description (Chapter 2.0)

- Process Information (Chapter 3.0)

- Waste Characteristics (Chapter 4.0)

- Groundwater (Chapter 5.0)

- Closure Performance Standards (Chapter 6.0)

- Closure Activities (Chapter 7.0) 
DOE/RL-90-04, Rev. 2

$12 / 15 / 93$

$1 \quad$ Postclosure (Chapter 8.0)
$2 \quad$ References (Chapter 9.0). sections.

A brief description of each chapter is provided in the following

\subsubsection{Facility Description (Chapter 2.0)}

This chapter provides a general description of the 303-K Storage Facility. A brief description and history of the Hanford Facility also are provided.

\subsubsection{Process Information (Chapter 3.0)}

This chapter covers the detailed operation of the 303-K Storage Facility. Additional information is given concerning the waste stored at the 303-K Storage Facility.

\subsubsection{Waste Characteristics (Chapter 4.0)}

This chapter discusses the estimate of maximum inventory of waste and the waste types stored at the 303-K Storage Facility.

\subsubsection{Groundwater (Chapter 5.0)}

This chapter explains that groundwater in the 300 Area will be included in the 300-FF-5 operable unit and cleaned up by the CERCLA remedial action process. Therefore, groundwater monitoring information is not included.

\subsubsection{Closure Strategy and Performance Standards (Chapter 6.0)}

This chapter outlines the closure strategy and the general closure procedure for the 303-K Storage Facility.

\subsubsection{Closure Activities (Chapter 7.0)}

This chapter contains a sampling plan and describes how the 303-K Storage Facility will be decontaminated and closed. A closure schedule is provided.

\subsubsection{Postclosure (Chapter 8.0)}

This chapter outlines provision for postclosure care if required. 
DOE/RL-90-04, Rev. 2

$12 / 15 / 93$

\subsubsection{References (Chapter 9.0)}

References used throughout this closure plan are listed in this chapter. All references 1 isted here, which are not available from other sources, will be made available for review, upon request, to any regulatory agency or public commentor. References can be obtained by contacting the following:

Administrative Records Specialist

Public Access Room H6-08

Westinghouse Hanford Company

P.0. Box 1970

Richland, Washington 99352 
DOE/RL-90-04, Rev. 2

$12 / 15 / 93$

$$
\begin{aligned}
& 1 \\
& 2 \\
& 3 \\
& 4 \\
& 5
\end{aligned}
$$

This page intentionally left blank.

$$
1-4
$$


DOE/RL-90-04, Rev. 2

$12 / 15 / 93$

\section{CONTENTS}

2.0 FACILITY DESCRIPTION . . . . . . . . . . . . . . . 2-1

2.1 FACILITY DESCRIPTION AND OPERATIONS ........... . . 2-1

2.2 SECURITY ..................... 2-3

\section{FIGURES}

2-1. Hanford Facility ................... F2-1

2-2. 300 Area . . . . . . . . . . . . . . . . . . F2-2

2-3. Plan View of the 303-K Storage Facility Surrounding Area . . . . F2-3

2-4. 303-K Storage Facility Site P1an . . . . . . . . . . . .

2-5. Plan View of the 303-K Storage Facility Showing the Year that Additional Storage Areas were Added .. . . . . . . . . . . . F2-5

2-6. Plan View of the 303-K Storage Facility . . . . . . . . . . . F2-6

2-7. Section View of the 303-K Storage Facility . . . . . . . . . F2-7 
DOE/RL-90-04, Rev. 2

$12 / 15 / 93$

$$
\begin{aligned}
& 1 \\
& 2 \\
& 3 \\
& 4 \\
& 5
\end{aligned}
$$

This page intentionally left blank. 


\subsection{FACILITY DESCRIPTION}

This chapter briefly describes the 303-K Storage Facility location (Figure 2-1), and provides information on the Hanford Facility security.

\subsection{FACILITY DESCRIPTION AND OPERATIONS}

The 303-K Storage Facility is located in the northwest portion of the 300 (Figure 2-2), near an asphalt roadway. Figure 2-3 shows the area around the 303-K Storage Facility in detail and indicates adjacent buildings. No 'legal' boundary exists for the 303-K Storage Facility. However, the boundary on the west side of the 303-K Storage Facility is Montana Street, the east side is Nevada Street, and the south side is Gingko Street. The boundary on the north side is 12 feet outside the 303-K Storage Facility fence (Figure 2$3)$. Operations began at the 303-K Storage Facility in 1943, and continue today. Detailed drawings of the 303-K Storage Facility are shown in Figures 2-4 through 2-7.

The 3707-G Building is a changeroom and not part of the 303-K Storage Facility or this closure plan. An aboveground drain from a sink and water fountain emptied into the west end of the 303-K Storage Facility trench until 1982.

The 303-K Storage Facility was designed and constructed in 1943. There is a sliding door on the north wall, a personnel door on the west wall, and there are no windows in the building. The cinder-block building has a poured concrete ceiling and no interior insulation or wallboard. The interior cinder-block walls were painted in 1977. The dimensions of the north end of the building are approximately 24.5 feet by 25 feet on the ground and 10 feet high. An $\mathrm{H}$-shaped drainage trench was added to the north end of the building in 1953, at the same time the cinder-block wall was built dividing the building into northern and southern halves.

The outside storage areas consist of two concrete pads, two asphalt pads, and a gravelled area. Figure 2-5 shows the dates the storage areas were added to the 303-K Storage Facility.

The north room of the 303-K Storage Facility originally had one electric-powered roof fan (size unknown). The fan might have been used from 1953 to 1977 while decontaminating aluminum spacers and equipment. However, weather permitting, the north room sliding door generally was open for material transfer during the decontamination of spacers and equipment.

The roof vent fan was replaced with a high-efficiency particulate air (HEPA) exhaust system in 1977 and was used until the fall of 1982

(Figure 2-7). The HEPA exhaust system was turned on only at the end of the curing operation for the concreted billets of recyclable scrap uranium chips and fines or if hydrogen levels indicated a billet fire had occurred. Air was discharged horizontally from the exhaust system approximately 13 feet above ground ( 2 feet above the roof). The flow rate of the exhaust system is

931119.1148 
unknown and there are no records of the HEPA filter efficiency tests. The HEPA exhaust system has not been used since the concrete curing operation was discontinued in 1982 .

During the aluminum spacer decontamination operation from 1953 to 1971, the chemicals and contaminants were removed via the process sewer (Figure 2-4). Discharges were from two sinks, a wash table, and the floor trench. Flow rates are unknown.

During the concretion curing operation from 1977 to 1982, steam condensate, sink and water fountain drainage from the 3707-G Building, and any cleanup water would have entered the process sewer via the floor trench drain. Flow rates are unknown.

After 1982, the only known liquid discharge was steam condensate. In 1988, the steam was shut off and the floor trench drain was sealed.

Surface run-off from precipitation entered the process sewer through the drain on the north concrete pad from 1953 until the drain was sealed in 1989.

There are no radiation detectors or sampling stations on the process sewer from the 303-K Storage Facility. Sampling was done at the outflow from the combined 300 Area process sewer system.

Various uses of the 303-K Storage Facility have been made (Chapter 3.0). At the present time, liquid waste is stored in DOT-approved containers (49 CFR 178) throughout the north room of the building.

A detailed description of the waste materials presently stored in the 303-K Storage Facility is presented in Chapter 4.0.

The outdoor concrete, gravel, and asphalt storage pads associated with the 303-K Storage Facility have been used since 1953 for storage of radioactive and mixed waste. The outside storage area is approximately 4,590 square feet (426 square meters). In 1978, a fence was constructed around the perimeter of the 303-K Storage Facility to control access into the area. At the present time, solid waste is stored on the outside storage areas in DOT-approved containers.

The 303-K Storage Facility has a drainage trench designed to remove or collect liquids resulting from spills, leaks, and/or daily operations. Standard spill-response procedures inside the building during the curing of concreted billets of recyclable scrap uranium chips and fines (1977 to 1982) included washing the spilled waste to the trench, where particulates settled out. The waste water drained into the 300 Area process sewer and the fines were shoveled from the trench and transferred to the 304 Concretion Facility to be reconcreted. The trench drain to the process sewer was sealed in 1988 . The trench can hold 229 gallons of liquid. 
DOE/RL-90-04, Rev. 2

$12 / 15 / 93$

\subsection{SECURITY}

The following describes the 24-hour surveillance system, warning signs, and barriers used to provide security and control access to the 303-K Storage Facility.

The entire Hanford Facility is a controlled access area. The Hanford Facility maintains around-the-clock surveillance for protection of government property, classified information, and special nuclear materials. The Hanford Patrol maintains a continuous presence of protective force personnel to provide additional security.

Within the Hanford Facility are operational areas to which access is restricted. One such operational area, the 300 Area, is the location of the 303-K Storage Facility. Access to the 300 Area is gained through one of three access points. All personnel accessing the 300 Area must display a DOE-issued security identification badge indicating appropriate authorization. Personnel also are subject to a search of items carried into and out of the area. Currently, there are no physical barriers (e.g., manned barriers, locked gates) limiting access to the 300 Area.

Signs are posted at area boundaries within the Hanford Facility stating "NO TRESPASSING. SECURITY BADGES REQUIRED BEYOND THIS POINT. GOVERNMENT VEHICLES ONLY. PUBLIC ACCESS PROHIBITED" (or an equivalent legend).

In addition, warning signs stating "DANGER--UNAUTHORIZED PERSONNEL KEEP OUT" (or equivalent legend) are posted at the 303-K Storage Facility. The signs are in English, legible from a distance of 25 feet, and are visible from all angles of approach. The 303-K Storage Facility is locked around the clock and onily authorized personnel have access. 
$\omega \rightarrow \omega N \cdots$

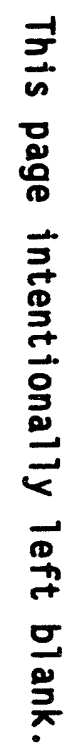

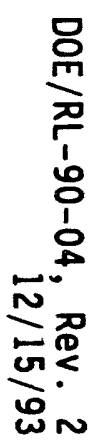


DOE/RL-90-04, Rev. 2

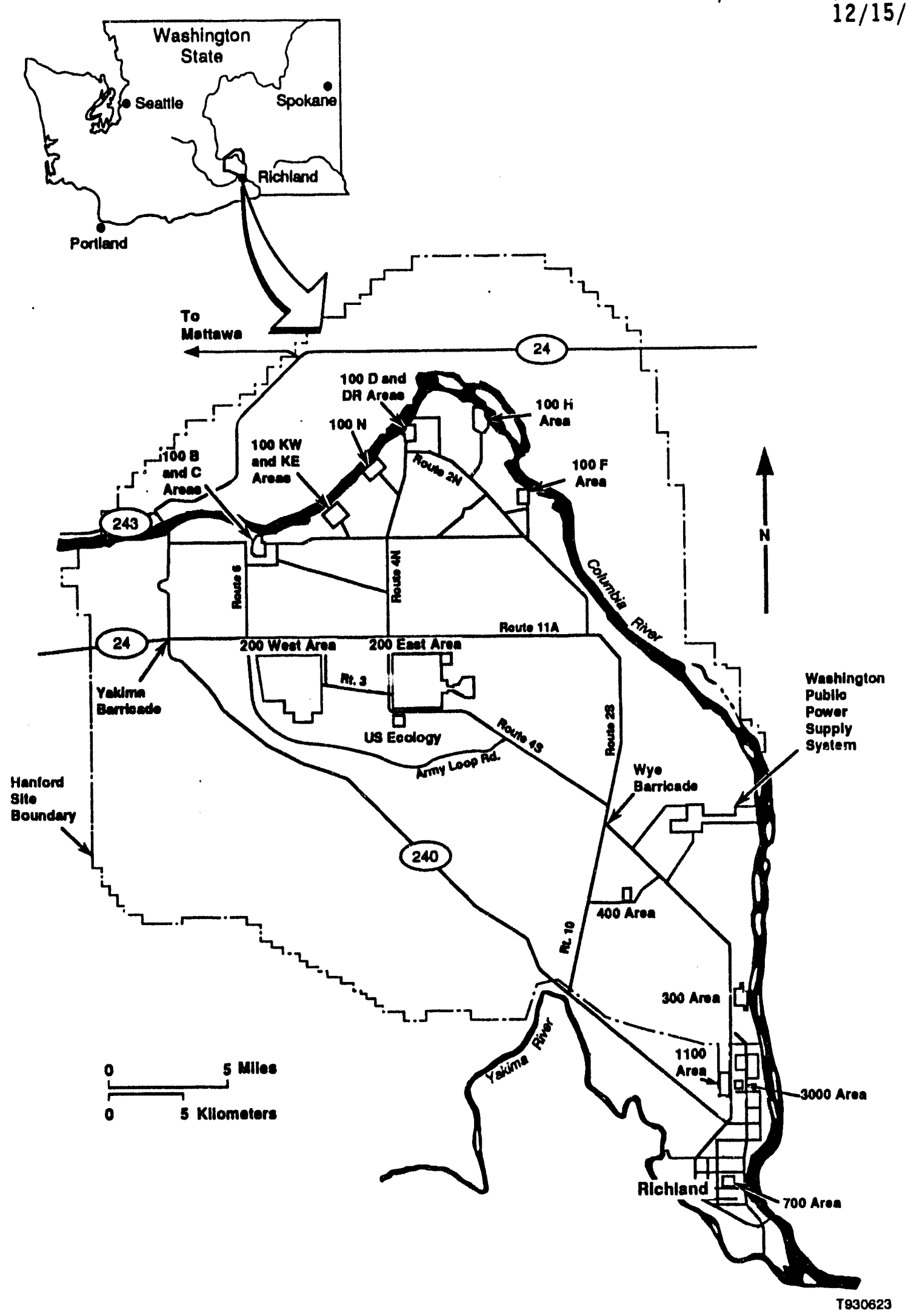

Figure 2-1. Hanford Facility 
DOE/RL-90-04, Rev. 2

$12 / 15 / 93$

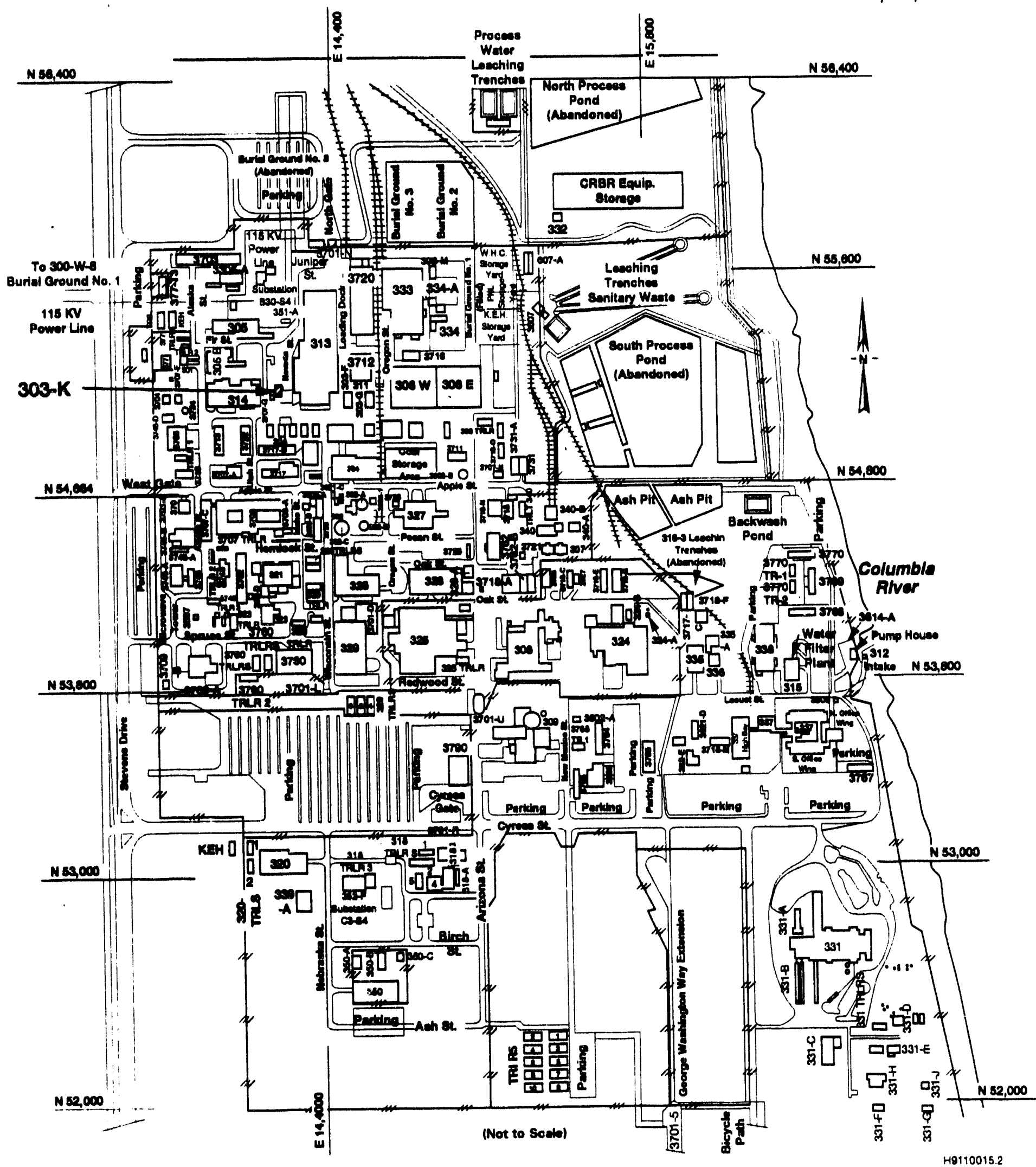

Figure 2-2. 300 Area. 


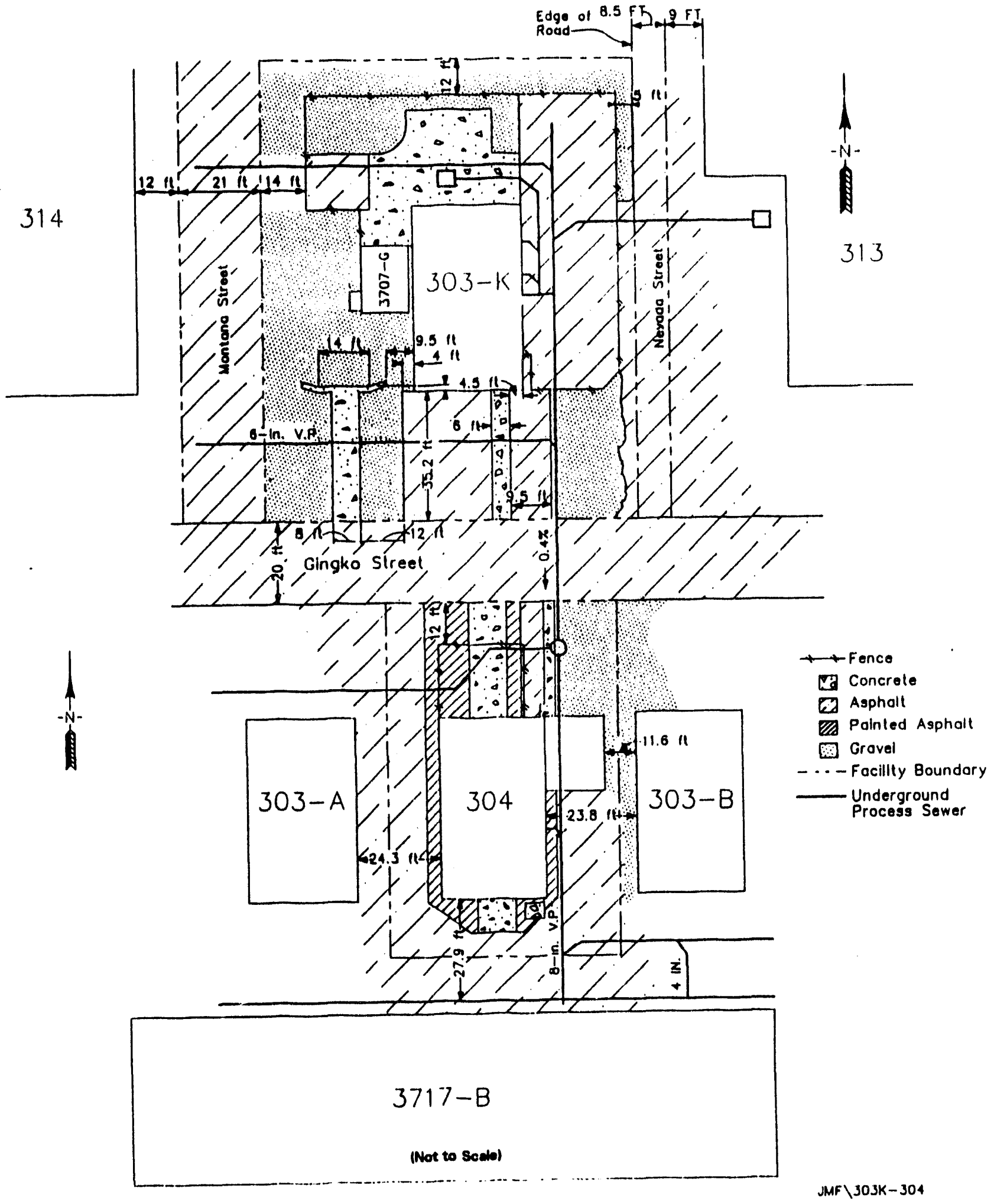

Figure 2-3. Plan View of the 303-K Storage Facility Surrounding Area. 


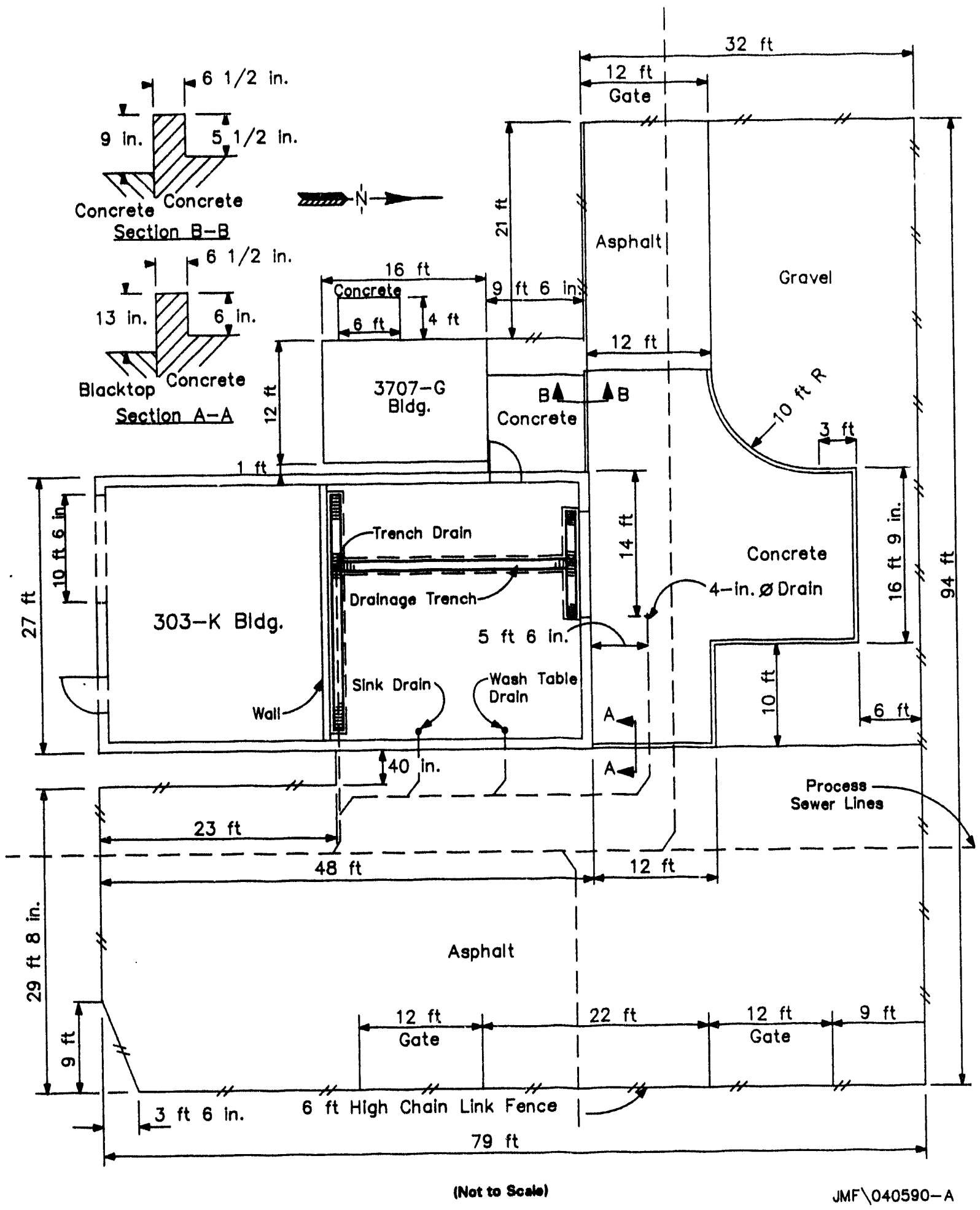

Figure 2-4. 303-K Storage Facility Site Plan. 


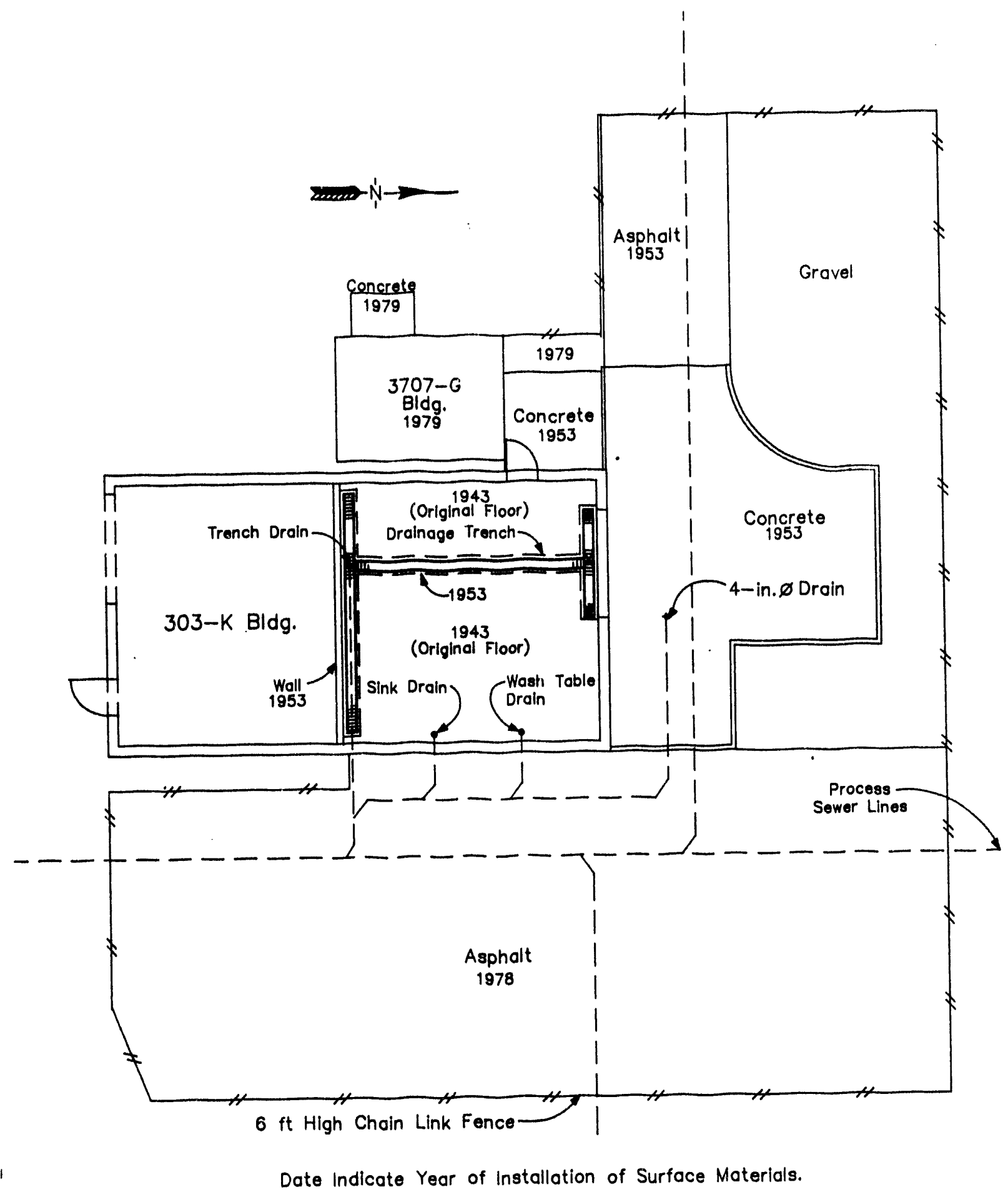

JMF $\backslash 050291-C$

Figure 2-5. Plan View of the 303-K Storage Facility Showing the Year that Additional Storage Areas were Added. 


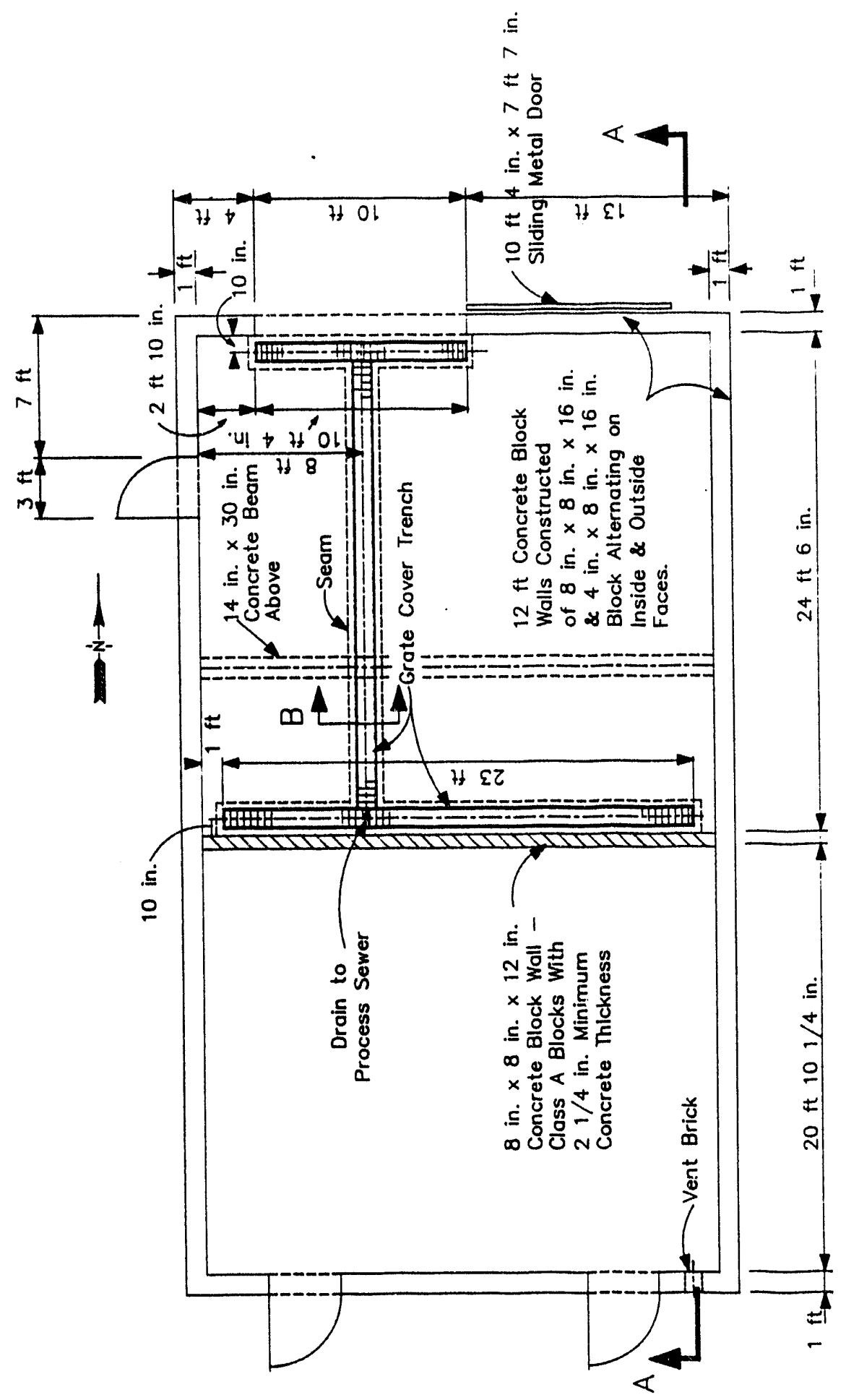

Figure 2-6. Plan View of the 303-K Storage Facility. 


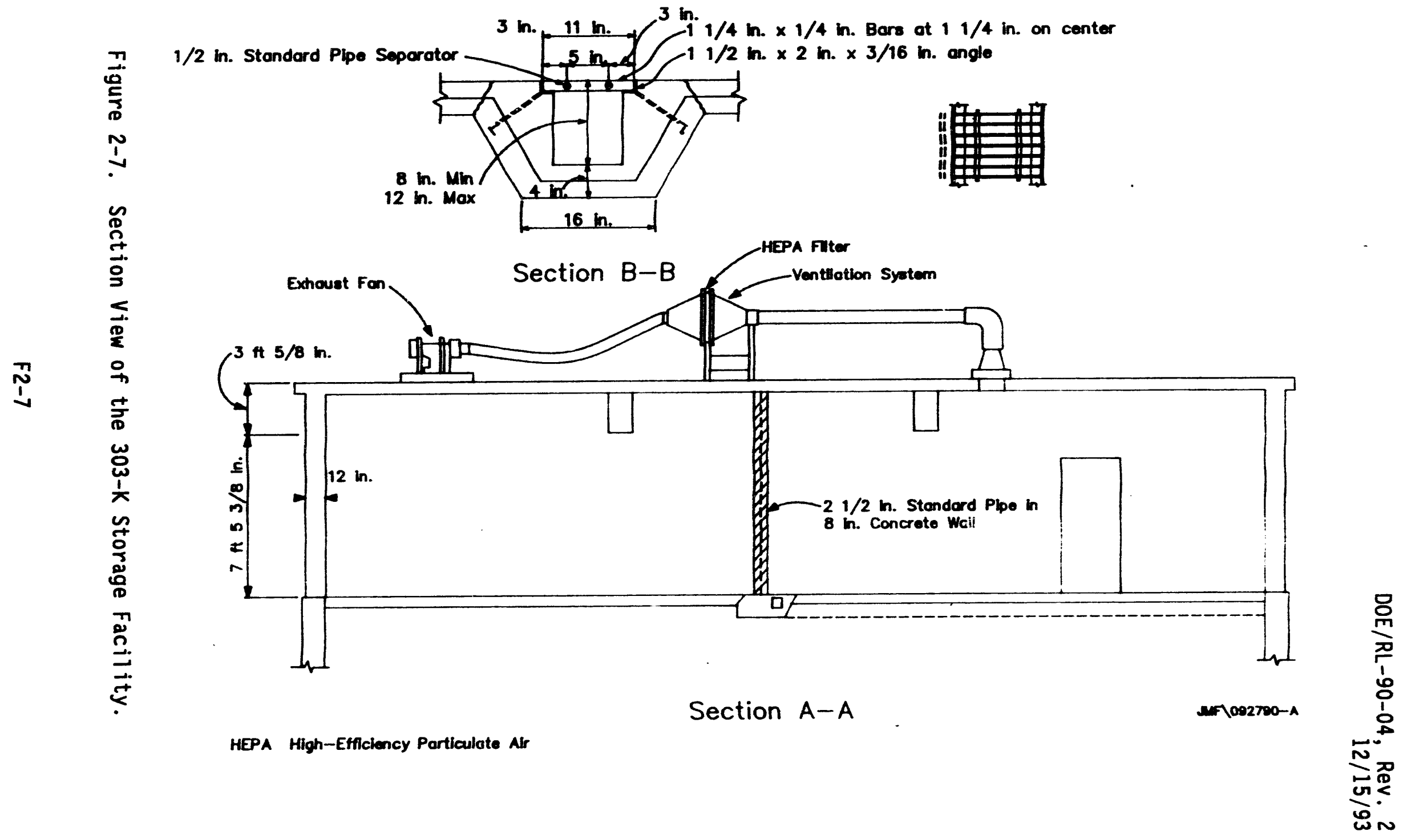


DOE/RL-90-04, Rev. 2

$12 / 15 / 93$

1

CONTENTS

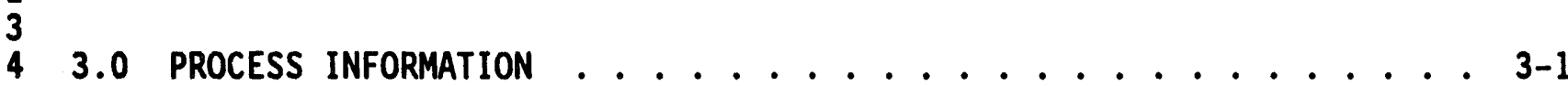


DOE/RL-90-04, Rev. 2

$12 / 15 / 93$

$$
\begin{aligned}
& 1 \\
& 2 \\
& 3 \\
& 4 \\
& 5
\end{aligned}
$$

This page intentionally left blank. 


\subsection{PROCESS INFORMATION}

The 303-K Storage Facility was designed and constructed in 1943 primarily for the storage of radioactive and mixed waste generated in the 300 Area.

Photographs of the 303-K Facility are shown in Appendix A. The following is a summary of the operational history.

- 1943 to 1953--the building was used to store uranium metal (in various shapes) and fuel elements (aluminum-canned uranium).

- August 1953--the building was remodeled to provide two rooms (north and south), and drainage trenches were added in the north room.

- 1953 to 1971--the north end of the building was used to remove radioactive contamination from aluminum spacers used in the reactors.

- 1953 to present--radioactive and mixed waste has been stored outside the building on concrete, gravel, and asphalt pads.

- 1971 to 1977--the north room was used for storage and removal of radioactive contamination from equipment.

- 1977--the north room was used to cure concreted billets (7.5-gallon container of concreted material) of recyclable scrap uranium chips and fines from the 304 Concretion Facility. The curing process was discontinued in the fall of 1982 .

- 1982 to 1986--equipment storage and the removal of radioactive contamination, using alkaline solutions (Table 4-2), continued at the 303-K Storage Facility.

- January 1986 to present--used for storage of containers filled with low-level radioactive waste and mixed waste.

The mixed waste stored after January 1986 is as follows (for a constituent list refer to Chapter 4.0, Table 4-1):

- Neutralized solid waste from the nonrecoverable uranium stream of the 300 Area Waste Acid Treatment System

- Uranium contaminated metallic lead

- Salt and sludge containers from beta and quench metal heat treatment furnaces

- Uranium contaminated perchloroethylene, 1,1,1 trichloroethane, and ethyl acetate

- Beryllium/zircaloy-2 alloy chips and fines generated at the stepcut lathe, before and after concreting at the 304 Concretion Facility 
- Spent coolant from counterbore lathes in the 333 Building

- Waste oil and hydraulic fluids that are known, or strongly suspected to be, contaminated with uranium

- Salt crystals (copper fluorozirconate) from the bottom of the waste storage tanks in the 334-A Building

- Acids ( $\mathrm{HNO}_{3}, \mathrm{HF}$, and $\mathrm{H}_{2} \mathrm{SO}_{4}$ mixtures) as a solution and absorbed on opal clay [Appendix $D$ contains material safety data sheets (MSDS)].

The north room of the 303-K Storage Facility was used to run tests on concreted recyclable scrap uranium chips and fines billets. Steam coils with thermostat controls regulated the curing temperature of billets, and a hydrogen detector was used to detect burning billets. The doors were sealed with plastic during curing cycles.

It is recognized that several factors associated with serious operations might have resulted in contamination of 303-K Storage Facility. These factors include radioactive decontamination procedures, waste stored and billet fires that occurred in 1979, 1980, and 1982. However, there are no records of spills or leaks. The evaluation of potential contamination at 303-K Storage Facility is described in Chapter 7.0, Section 7.3. 


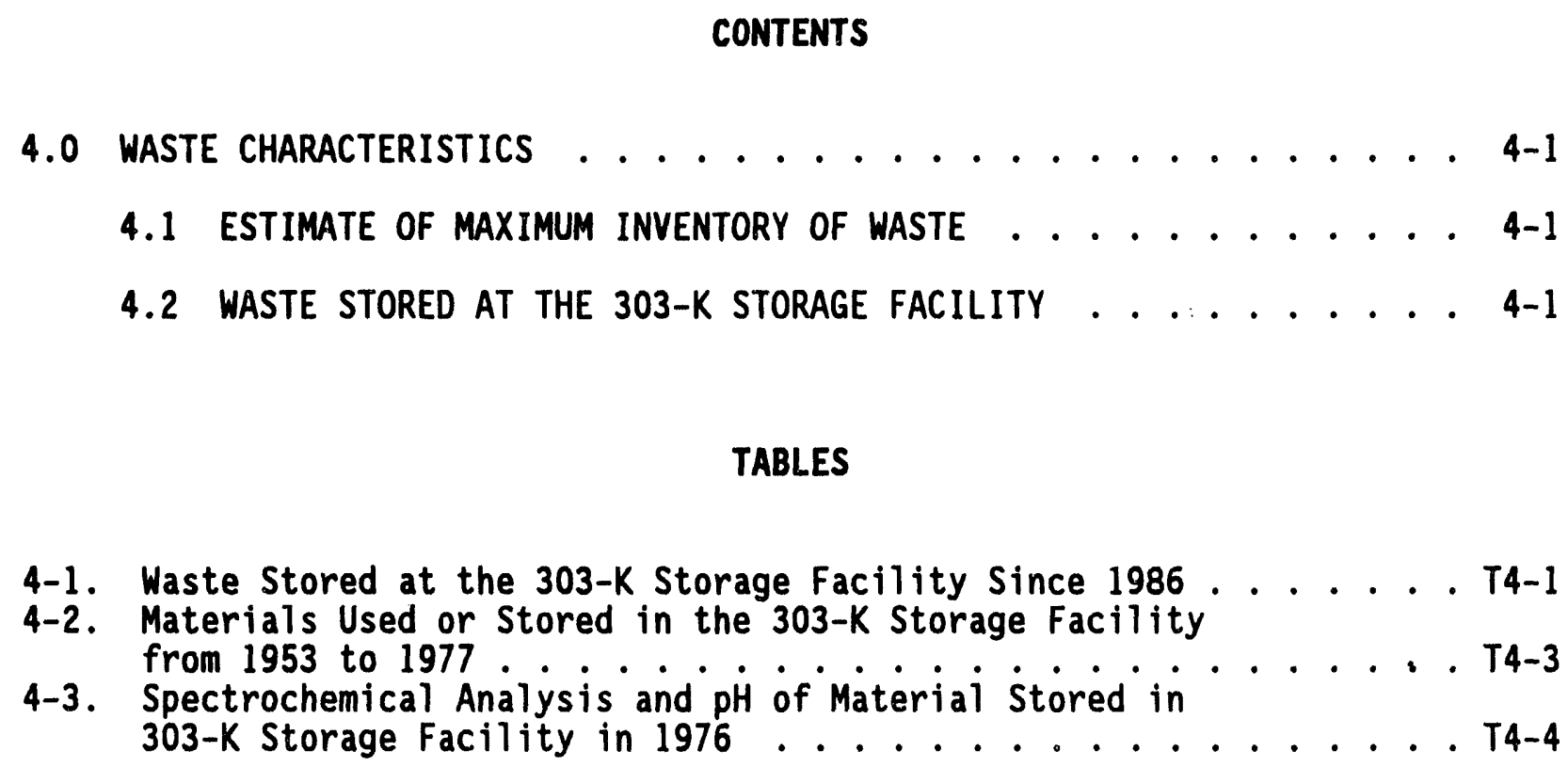


DOE/RL-90-04, Rev. 2

$12 / 15 / 93$

$$
\begin{aligned}
& 1 \\
& 2 \\
& 3 \\
& 4 \\
& 5
\end{aligned}
$$

This page intentionally left blank. 
DOE/RL-90-04, Rev. 2

$12 / 15 / 93$

\subsection{WASTE CHARACTERISTICS}

This chapter addresses the waste inventory and waste forms treated at the 303-K Storage Facility.

\subsection{ESTIMATE OF MAXIMUM INVENTORY OF WASTE}

The maximum estimated inventory of containerized waste stored inside the 303-K Storage Facility is 200 containers or 11,000 gallons of waste. This total includes container sizes (not including overpacks) of 55, 30, and 7.5 gallons. Some of these containers contain lab-packs, and some containers are partially filled.

\subsection{WASTE STORED AT THE 303-K STORAGE FACILITY}

Waste normally is received in 85-gallon overpack drums and DOT-approved 55-, 30-, and 7.5-gallon containers. Solvents are received in 17-H closed-head containers or 30-gallon stainless-steel containers. No waste is received at the 303-K Storage Facility in bulk loads. The 303-K Storage racility received a variety of chemical and radiological waste that was generated by the fuels manufacturing processes in the 300 Area, including waste oils and cutting lubricants, concreted waste from the 304 Concretion Facility, metal heat-treatment salts (quench and beta), salt crystals from the waste acid tanks in the 334-A Building, degreaser solvents, acid absorbed on opal clay, and solids from the 313 Building waste acid treatment system. Waste is designated according to Ecology waste designation regulations in WAC 173-303-070. Waste descriptions are provided in Table 4-1.

There were no detailed procedures used for acceptance of waste at the 303-K Storage Facility. The 303-K Storage Facility serviced known manufacturing processes with known waste byproducts. All waste and contaminated equipment from radiation areas; or those suspected to contain uranium, were sent to the 303-K Storage Facility.

Most waste containers were sampled before transfer to the 303-K Storage Facility. The analysis was not always received before the drums were moved to the 303-K Storage Facility. A few containers were sampled after the containers were received at the 303-K Storage Facility. These analyses were performed primarily to determine the content of uranium for accountability purposes or to determine if the radioactivity was naturally occurring. Waste determined to contain de minimis quantities of uranium or naturally occurring radioisotopes was moved to the 333 East Pad until proper permits were obtained and the waste was transferred out in less than 90 days. Analytical records, from 1987 to present, are available for review to substantiate the waste codes contained in the Part $A$ permit application. 
Hanford Facility operations contribute waste to the 303-K Storage Facility under the common U.S. Environmental Protection Agency (EPA)/state identification number. The 303-K Storage Facility receives waste generated onsite from more than one source.

Table 4-2 shows the chemicals (MSDSs not listed) used and stored in the 303-K Storage Facility, from 1953 to 1977, during the decontamination of aluminum spacers and equipment. Table 4-3 shows the spectrochemical analysis and $\mathrm{pH}$ of material used in the decontamination of equipment and four containers that contained caustic material stored in the $303-K$ Storage Facility in 1976.

From the fall of 1979 through March 1980, during the testing program in the northern half of the 303-K Storage Facility, a total of 14 billets burned. Another 12 billets burned in the 303-K Storage Facility on March 13, 1982. The March 13, 1982 fire required assistance from the Hanford Fire Department because wooden pallets caught on fire. After the fires had burned out, burned billet debris was reconcreted in the 304 Concretion Facility, and the walls, ceiling, and floor were decontaminated by hosing with water that discharged to the process sewer. Uranium oxide and small amounts of copper oxide and zirconium oxide were formed by the burning billets but were removed by the decontamination procedure. Air samples and radiation surveys in the general area indicated no contamination release. Appendix $C$ contains the Occurrence Report. 
Table 4-1. Waste Stored at the 303-K Storage Facility Since 1986. (sheet 1 of 2)

4 Organic Constituents

5 Perchloroethylene

6 Trichloroethylene

7 1,1,1-Trichloroethane

8 Methyl ethyl ketone

9 Toluene

10 Pentachlorophenol

11 Tetrachloroethylene

12 Ethyl Acetate

13 Hydraulic oil

14 Organic Degradation Products

15 1,1-Dichloroethylene

16 cis-1,2-Dichloroethylene

17 trans-1,2-Dichloroethylene

18 Vinyl chloride

19 Inorganic Constituents

20 Acid $\left(\mathrm{HNO}_{3}, \mathrm{HF}, \mathrm{H}_{2} \mathrm{SO}_{4}\right)$

21 Arsenic ion

22 Barium ion

23 Beryllium/zircaloy-2

24 Cadmium ion

25 Chromium ion
Waste Description

\section{Waste type}

Spent halogenated solvent Spent halogenated solvent Spent halogenated solvent Spent nonhalogenated solvent

Spent nonhalogenated solvent

Unknown solid block balls from Heating,

Ventilation, Air Conditioning (HVAC) Room in the 313 Bldg.

Spent halogenated solvent Spent nonhalogenated solvent

Contaminated with halogenated hydrocarbons

Spent halogenated solvent Spent halogenated solvent Spent halogenated solvent Spent halogenated solvent

Crystals, solution, absorbed on opal clay Solution, sludge Solution, sludge Metal alloy Solution, sludge Solution, sludge 
1 Table 4-1. Waste Stored at the 303-K Storage Facility Since 1986. (sheet 2 of 2)

3 Waste Description

4 Inorganic Constituents

5 (continued)

6 Lead

7 Uranium

8 Mercury ion

9 Silver ion

10 Zircaloy-2"

11 Quench salt

$12 \mathrm{KNO}_{3}, \mathrm{NaNO}_{3}$,

$13 \quad \mathrm{NaNO}_{2}$ )

14 Beta salt

15 (KCl, NaCl)

16

17

18

19

20

21

Composed of zirconium with

Waste Type

Metal

Metal, oxide, solution, sludge

Solution, sludge

Solution, sludge

Metal alloy

Solid salt

Solid salt
$1.2-1.7 \%$ tin
$0.07-0.2 \%$ iron
$0.05-0.15 \%$ chromium
$0.03-0.08 \%$ nickel. 
Table 4-2. Materials Used or Stored in the 303-K Storage Facility from 1953 to 1977.

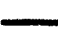

Process

4 Removal of radioactive contamination

Sodium hydroxide, $\mathrm{NaOH}$.

5 from used aluminum spacers. (A11 used

Sodium nitrate, $\mathrm{NaNO}_{3}$.

solutions and rinse water were

discharged to the process sewer and

were known to contain small amounts of
${ }^{55} \mathrm{Zn},{ }^{95} \mathrm{Zr},{ }^{95} \mathrm{Nb},{ }^{46} \mathrm{Sc},{ }^{59} \mathrm{Fe},{ }^{60} \mathrm{Co}$, and

${ }_{10}^{9}{ }^{58} \mathrm{Co}$, ,

11 Removal of radioactive contamination

12 from equipment. (A11 used solutions

13 and rinse water were discharged to the

14 process sewer and were known to contain small amounts of uranium and thorium.)

Steam.

Sodium aluminate solution, $\mathrm{NaAlO}_{2}$.

Turco Aluminetch \#2.

Diversey \#202 Aluminum Cleaner.

American Equipment \& Supply, A11

Purpose Synthetic Cleaner.

Diversey RX-1288.

Turco Alkaline Rust Remover.

Containers of unknown caustic material.

Refer to Table 4-3 for spectrochemical analysis and $\mathrm{pH}$.

"Turco is a trademark of Turco Products Incorporated.

20 
i Table 4-3. Spectrochemical Analysis and pH of Material Stored in the 303-K Storage Facility in 1976.

\begin{tabular}{|c|c|c|c|c|c|c|c|c|c|c|c|c|c|c|c|c|c|}
\hline \multirow{2}{*}{ Material } & \multirow{2}{*}{ pH } & \multicolumn{16}{|c|}{ Content in ppm or percent as indicated } \\
\hline & & Al & Ba & Ca & cd & co & $\mathrm{Cr}$ & cu & Fe & Mo & in & Ma & $M i$ & P & $\mathrm{Pb}$ & si & Sr \\
\hline $\begin{array}{l}\text { Sodium aluminate } \\
\text { solution }\end{array}$ & 10.5 & 1.000 & & & & & & 40 & 20 & & & $4 x$ & 200 & & & 1,000 & \\
\hline Turco ${ }^{\star}$ Aluminetch & 11.8 & 2 & & & & 50 & & & & & & $>10 x$ & & 200 & 5 & 5 & \\
\hline $\begin{array}{l}\text { Diversey } \\
\text { Cleaner }\end{array}$ & 11.2 & & & 50 & & & & & & & & $10 x$ & & 12 & & & \\
\hline $\begin{array}{l}\text { American Equipment \& } \\
\text { Supply All Purpose } \\
\text { Cleaner }\end{array}$ & 11.2 & & & 6 & & & & 10 & 6 & & & 6,000 & & 1,000 & & $1 x$ & \\
\hline Diversey RX-1288 & 9.2 & 20 & & 200 & & & & & 50 & 1 & 2 & $>10 x$ & & $1 x$ & & $2 x$ & \\
\hline $\begin{array}{l}\text { Turco Alkal ine Rust } \\
\text { Rewover }\end{array}$ & unk & 10 & & & & & & & & & 5 & $10 x$ & & & & 100 & 20 \\
\hline Containers of Unknoun: & & & & & & & & & & & & & & & & & \\
\hline Container $\$ 14$ & Besic & 500 & & 2,000 & & & 10 & 1 & 50 & 10 & 5 & $>10 x$ & 50 & & 5 & 1,000 & 50 \\
\hline Container $\$ 31$ & 8.5 & 5 & & 300 & 6 & & & 3,000 & & 10 & & 60 & 30 & & & 10 & \\
\hline Container $\$ 39$ & Basic & 40 & 2 & 4 & & & 4 & & 90 & 1 & 90 & 900 & 1 & & 0.1 & 20 & \\
\hline Container $\$ 40$ & Basic & 1,000 & 50 & 200 & & & 10 & & 500 & 10 & 5 & $>10 \%$ & 100 & & & 100 & 20 \\
\hline
\end{tabular}

19 Turco is a trademark of Turco Products Incorporated.

20 - Diversey is a trademark of Diversey Wyandotte Corporation.

$21 \quad \mathrm{ppm}=$ parts per million.

$22 \quad$ ukn $=$ unknown

23 
DOE/RL-90-04, Rev. 2

$12 / 15 / 93$

\section{CONTENTS}

5.0 GROUNDWATER ....................... 5-1

\section{FIGURE}

10

11

5-1. Boundary of the 300-FF-5 Operable Unit . . . . . . . . . . . F5-1 
DOE/RL-90-04, Rev 22

$12 / 15 / 93$

This page intentionally left blank. 
DOE/RL-90-04, Rev. 2

$12 / 15 / 93$

\subsection{GROUNDWATER}

In accordance with the Tri-Party Agreement (Ecology et a1. 1992), groundwater in the 300 Area will be included in the 300-FF-5 operable unit and cleaned up as part of the CERCLA remedial action process. Therefore, groundwater is not included as part of the 303-K Storage Facility Closure Plan. The remedial investigation/feasibility study (RI/FS) draft work plan for the 300-FF-5 operable unit was prepared in 1989 (DOE-RL 1989).

The 300-FF-5 operable unit consists of the aquifer beneath the 300-FF-1, $300-F F-2$, and 300-FF-3 operable units and is bounded by the Columbia River on the east (Figure 5-1). The operable unit is defined by "the observed and assumed extent of uranium contamination in the groundwater" (DOE-RL 1989). Ultimately, the operable unit will include all contamination exceeding applicable or relevant and appropriate requirements emanating from the three operable units as detected in groundwater and sediments below the water table.

The Tri-Party Agreement Action Plan (Ecology et al. 1992) indicates the record of decision for the 300-FF-5 operable unit will be issued in 1994, the remedial design will be performed in 1995, and the remedial action will begin in 1996.

The remedial action objectives for the 300-F-5 operable unit will be based on the following general objectives:

- Frotect human health by ensuring that applicable or relevant and. appropriate requirements will not be exceeded, and health risks, as determined through analysis of all exposure pathways, will be kept at or below acceptable limits

- Ensure acceptably low risks to the environment, such as Columbia River biota. 
DOE/RL-90-04, Rev. 2

$12 / 15 / 93$

1
2
3
4
5

This page intentionally left blank. 
DOE/RL-90-04, Rev. 2

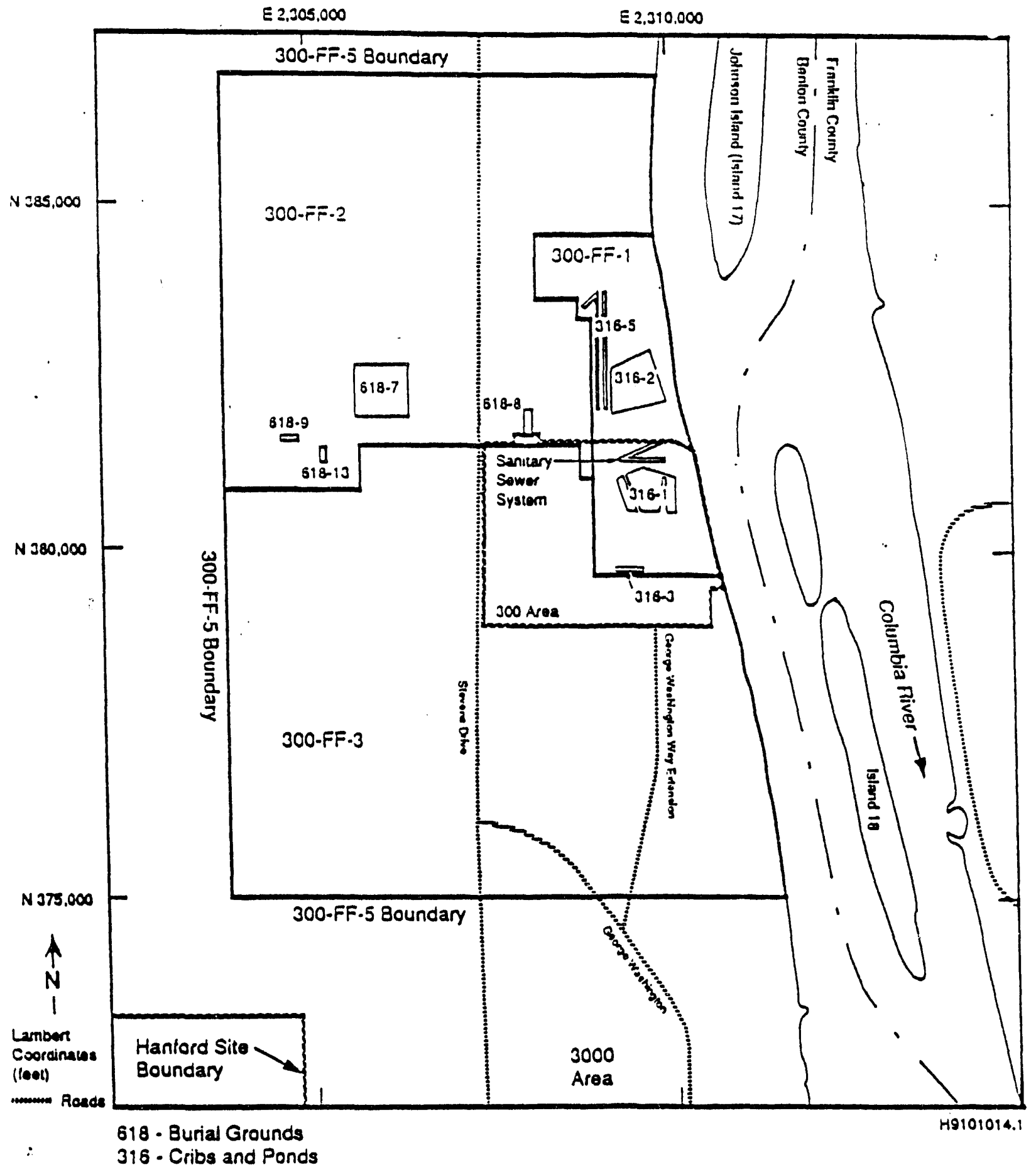

Figure 5-1. Boundary of the 300-FF-5 Operable Unit. 
DOE/RL-90-04, Rev. 2

$12 / 15 / 93$

1

2

\section{CONTENTS}

6.0 ClOSURE STRATEgY AND PERFORMANCE STANDARDS . . . . . . . . . . 6-1

6.1 Closure STRATEGY . . . . . . . . . . . . . 6-1

6.2 GENERAL ClOSURE APPROACH ................. 6-2

6.3 Minimized NeEd For further MaintenANCE . . . . . . . . 6-3

6.4 PROTECTION OF hUMAN HEALTH AND THE ENVIRONMENT .......

6.5 RETURN OF LAND TO THE APPEARANCE AND USE OF SURROUNDING LAND AREAS....................... 6-3

FIGURE

6-1. 303-K Storage Facility Closure Flowchart . . . . . . . . . F6-1 
DOE/RL-90-04, Rev. 2

$12 / 15 / 93$

1
2
3
4
5

This page intentionally left blank. 
DOE/RL-90-04, Rev. 2

$12 / 15 / 93$

\subsection{CLOSURE STRATEGY AND PERFORMANCE STANDARDS}

This chapter discusses the closure strategy, performance standards for protection of health and the environment, and closure activities.

\subsection{CLOSURE STRATEGY}

The closure strategy for the 303-K Storage Facility is to decontaminate to remove known or suspected contamination, followed by sampling for the constituents of concern, followed by data analysis, with an evaluation to determine the required actions to meet closure criteria. The closure criterion for the 303-K Storage Facility is to verify that potentially dangerous constituents treated, stored, or used in the 303-K Storage Facility are not present above action levels. If the potentially dangerous constituents are above action levels, an action level evaluation will determine the actions required. Figure 6-1 shows the closure strategy for the 303-K Storage Facility.

The action level evaluation would consider (1) the type and extent to which the action levels are exceeded and (2) assessment of health-based risk. Health-based risk standards for toxicity and carcinogenicity will be scientifically and technically defensible, and criteria guidance will be used, such as WAC 173-340, the Integrated Risk Information System (IRIS) database (EPA 1991), the Human Health Evaluation Manual (EPA 1989b), and other appropriate information.

To facilitate closure, the 303-K Storage Facility will be divided into four components: the building; the floor; the pads (concrete and asphait); and the soil. These four components will be evaluated separately for closure.

If dangerous constituents exist in the building and building components in concentrations above action levels, additional decontamination will be performed if the additional decontamination is considered to be effective. If decontamination is not effective, the appropriate section (building, floor, or pad) will be removed and properly disposed of as dangerous waste.

If dangerous constituents are identified in the soil in concentrations above action levels, closure for the soil will take place during the remediation of the 300-FF-3 operable unit under the CERCLA remedial action process. Soils that would be considered an imminent hazard would be remediated as specified by the Hanford Federal Facility Agreement (Ecology, et al., 1990) Action Plan Section 7.2.3.

Because the process sewer system is scheduled to be addressed under the 300-FF-3 operable unit CERCLA remedial action process, it is not included in this closure plan. The process sewer system is considered to begin immediately beneath the building floor and pads. Soil samples will not be obtained in proximity to the process sewer. 
Action levels are concentrations of constituents of concern that prompt an action, such as removal-disposal, treatment, or further evaluation. Initial action levels will be the greater of two levels: background or limit of quantitation (LOQ). Background will be sitewide soil background concentrations as defined in Hanford Facility Soil Background (DOE/RL 1992). The LOQ is generally 10 times the standard deviation replicate analyses and a method block on low concentration sample. If concentrations exceed initial action levels, health-based action levels (HBL) will be assessed.

The HBLs will be based on equations and exposure assumptions presented in the Hanford Facility Baseline Risk Assessment Methodology (DOE-RL 1992). For noncarcinogens, the principal variable relating human health to action levels is the oral reference dose. The reference dose is defined as the level of daily human exposure at or below which no adverse effect is expected to occur during a lifetime. For carcinogens, the cancer slope factor is the basis for determining human health effects; it is a measurement of risk per unit dose. The oral reference dose and cancer slope factor are chemical-specific and are obtained from the Integrated Risk Information System (IRIS) database (EPA 1993). Health-based levels will be based on values that are current at the time of approval of this closure plan.

\subsection{GENERAL CLOSURE APPROACH}

The 303-K Storage Facility will be closed in a manner consistent with WAC 173-303. The general closure approach (Figure 6-1) is as follows:

- Remove dangerous waste inventory

- Decontaminate the building components, building walls, ceiling, floor, and outside storage pads using one of the options described in Chapter 7.0, Section 7.4

- Collect samples from the building, floor, and outside storage pads

- Collect soil samples under the floor and pads in areas with potential pathways to the soil if required

- Conduct analytical testing of samples and evaluate data

- Compare data to action levels

- Conduct additional decontamination of building and outside storage pads if required

- Collect and analyze samples to support additional decontamination, if required

- If decontamination procedures do not remove contamination to action levels, remove that portion of the building, floor, or pad 
- Soll remediation, if required, will be accomplished under the CERCLA remedial action process.

Al1 equipment used in performing closure activities will be decontaminated or disposed of at a permitted facility.

Closure activities will be monitored by an offsite independent registered professional engineer who will certify that, in his or her judgment, closure was accomplished in accordance with the specifications of the approved closure plan as described herein. The professional engineer's report will be submitted to the EPA and Ecology along with certification of closure. The report and certification will be sent by registered mail or an equivalent delivery service.

The closure activities will be completed in accordance with the schedule contained in this closure plan after the schedule is approved by Ecology and EPA. Two official copies of this closure plan will be located at the following office: U.S. Department of Energy, Richland Operations Office (DOE-RL), Federal Building, 825 Jadwin Avenue, P.0. Box 550, Richland, Washington 99352. The DOE-RL office will be responsible for amending this plan, as amendments become necessary, according to the amendment procedure identified in WAC 173-303-610. The plan will be kept at the DOE-RL office until closure is complete and certified. Other official copies will be kept by Ecology, the EPA, Administrative Record Center, the 303-K Storage Facility manager's office, and at the 303-K Storage Facility site.

\subsection{MINIMIZED MEED FOR FURTHER MAINTENANCE}

Closure of the 303-K Storage Facility by removing or decontaminating (to proposed action levels) equipment, bases, structures, and other materials contaminated with dangerous waste or waste residues will eliminate the need for further maintenance. However, interim actions might be required if soils are left in place for remediation under the CERCLA remedial action process. These interim actions are described in Chapter 8.0, Section 8.2.

\subsection{PROTECTION OF hUMAN HEALTH AND THE ENVIRONMENT}

As discussed previously, the 303-K Storage Facility will be closed by removing or decontaminating, to proposed action levels, all dangerous waste and waste residues to protect human heaith and the environment.

\subsection{RETURN OF LAND TO THE APPEARANCE AND USE OF SURROUNDING LAND AREAS}

After closure of the 303-K Storage Facility is accomplished, the site will be returned to the appearance and continued use of the surrounding 300 Area (e.g., a weedless gravel lot). 
DOE/RL-90-04, Rev. 2

$12 / 15 / 93$

This page intentionally left blank. 


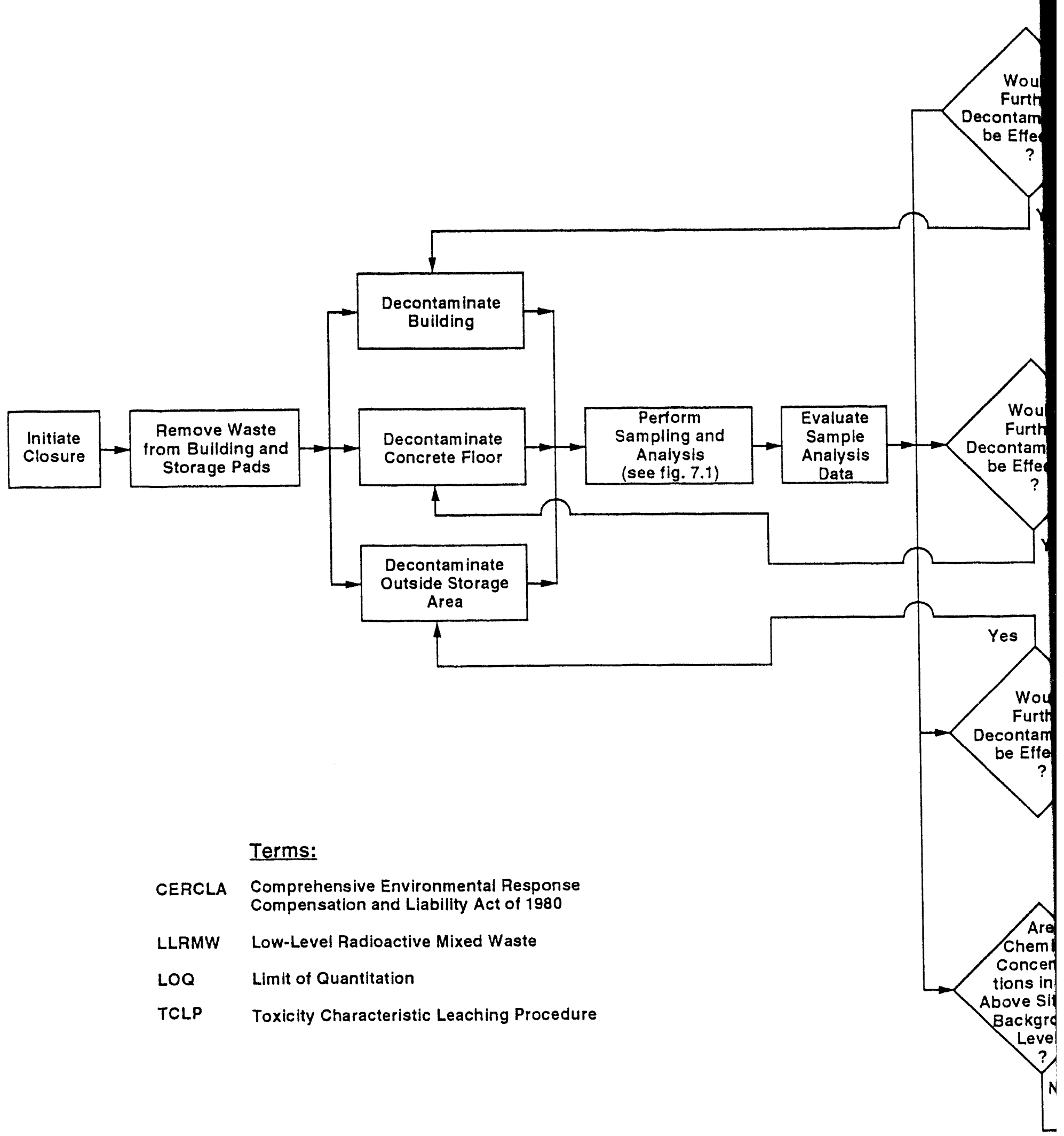




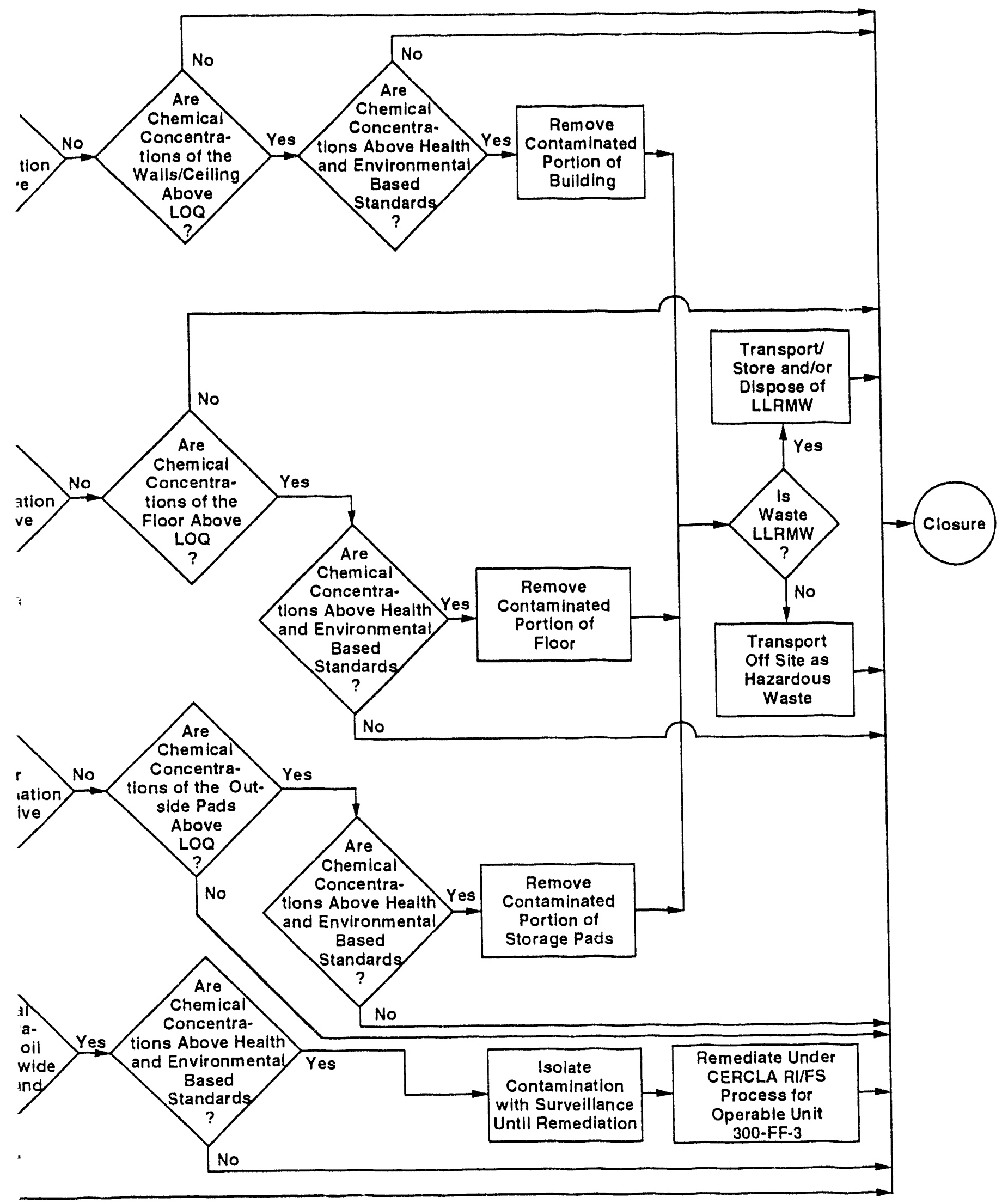

Figure 6-1. 303-K Facility Closure Flowchart. 
CONTENTS

7.0 Closure activities . . . . . . . . . . . . . . . . 7-1

7.1 REMOVAL OF DANGEROUS WASTE INVENTORY .......... 7-1

7.2 FACILITY SAMPLING ................ . . . . .

7.2.1 Sampling Design .............. . . . . .

7.2.1.1 objectives ............ 7-1

7.2.1.2 Analytical Parameters . . . . . . . . 7-2

7.2.1.3 Sampiling Activities . . . . . . . . . . 7-2

7.2.1.4 Sampling Procedures . . . . . . . . . 7-2

7.2.1.5 Sampling Locations ........... 7-5

7.2.1.6 Data Quality ......... 7-6

7.2.2 Modifications to the Waste Sampiing and Anaiysis

Plan ................. 7-7

7.2.3 Data Evaluation Process ........... 7-7

7.2 .4 Statistical Treatment of Data .......... 7-7

7.2.5 Assessment of Data Reliability . . . . . . . . 7-8

7.2 .6 Reporting ............... 7-8

7.2.7 Sampling Equipment, Containers, and Preservation . . . 7-9

7.2.7.1 Sampling Equipment ......... 7-9

7.2.7.2 Sample Containers and Preservation ..... 7-10

7.2.8 Sampling Quality Control ........... 7-10

7.2.8.1 Field Quality Control . . . . . . . . 7-10

7.2.8.2 Field Logbook . . . . . . . . . . . 7-11

7.2.8.3 Sample Labels . . . . . . . . . . . . 7-12

7.2.8.4 Sample Seals ............ . 7-12

7.2.8.5 Chain-of-Custody Records ........ . 7-12

7.2.8.6 Sample Analysis Request ......... . . 7-13

7.2.8.7 Laboratory Receipt and Logging of Sample . . . 7-13

7.2.8.8 Sample Disposition .......... 7-14

7.2.8.9 Decontamination . . . . . . . . . . 7-14

7.2.9 Analytical Procedures ........... . . . . . . . 7.2.9.1 Concrete and Asphait Inorganic Analysis

Methodology ......... 7-14

7.2.9.2 Concrete and Asphait Organic Analys is Methodology .......... 7-15

7.2 .10 Laboratory Qual ity Control ........... 7-15

7.2 .11 Site Safety ............... . . . .16

7.2.11.1 Health and Safety Plan ......... 7-16

7.2.11.2 Contamination Control ........ 7-16

7.2.11.3 Personnel Training .......... . 7-17

7.2.11.4 Standard Safety Procedures . . . . . . . 7-17

7.3 REMOVAL OF CONTAMINATED MATERIAL AND WASTE RESIDUES . . . . . 7-18

7.4 DECONTAMINATION AND DISPOSAL OF BUILDING AND CONCRETE PAD . . . 7-18

7.5 OTHER ACTIVITIES REQUIRED FOR CLOSURE . . . . . . . . . 7-19 
7-1. Waste Sampling and Analysis Flowchart ......... F7-1

7-2. 303-K Storage Facility, Floor Core Sampling Locations...... . F7-2

7-3. 303-K Storage Facility, Sampling Locations on Outside Storage

Pads and in Gravel Area .................. . . F7-3

7-4. 303-K Storage Facility Sampling Locations in Areas of Potential Contamination . . . . F7-4

7-5. 303-K Storage Facility, South Wail (Inside) and North Wall

Sampling Locations ............... . . F7-5

7-6. 303-K Storage Facility, East and West Wall Sampling Location . . F7-6

7-7. 303-K Storage Facility, Celling Sampling Locations . . . . . . F7-7

7-8. 303-K Storage Facility Closure Schedule . . . . . . . . . F7-8

7-9. Closure Certification for the 303-K Storage Facility . . . . . F F-9

7-1. Potential Compliance Constituents, Analytical Methods, and Action Levels for the 303-K Storage Facility . . . . . . . T7-1

7-2. Sampling Summary of the 303-K Storage Facility . . . . . . . T7-2

7-3. Field Quality Control Samples . . . . . . . . . . . . . T7-3

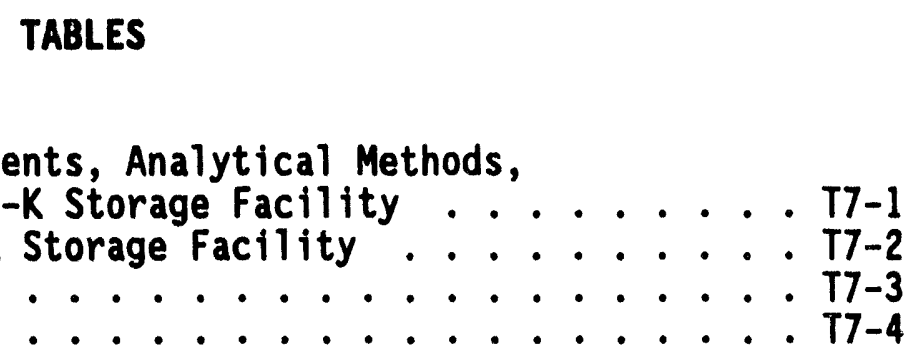


DOE/RL-90-04, Rev. 2

$12 / 15 / 93$

20

\subsection{CLOSURE ACTIVITIES}

This chapter describes the activities necessary to close the 303-K Storage Facility. Included is a sampling and analys is plan, and a schedule for completing the closure activities once the closure plan is approved. The overall strategy, on which the sampling and analys is plan is based, is described in Chapter 6.0.

\subsection{REMOVAL OF DANGEROUS WASTE INIVENTORY}

The outdoor storage areas and the north half of the 303-K Storage Facility currently are in use as a greater-than-90-day storage unit. After the closure plan is approved and before any other closure activities are conducted, all waste stored at the 303-K Storage Facility will be transferred to the Central Waste Complex for interim storage and future treatment or disposal.

\subsection{FACILITY SAMPLING}

The following waste sampling and analysis plan has been prepared to evaluate contamination levels, if any, within the north half of the building, the outside storage areas, and near-surface soils associated with the 303-K Storage Facility. The south half of the building was not used for dangerous waste-related activities and is not included in this closure plan. The north and south halves of the building are separated completely by a cinder block wall. The other walls also are constructed of cinder block, and the building has a concrete floor and ceiling. This plan is based primarily on the history of the processes associated with the 303-K Storage Facility (Chapter 3.0).

A flowchart for sampling activities is provided in Figure 7-1. The 303-K Storage Facility is regulated by WAC 173-303, but located within a CERCLA operable unit. Because the 303-K Storage Facility is located in a CERCLA operable unit (300-FF-3), any soil remediation will be accomplished under the CERCLA remedial action process.

\subsubsection{Sampling Design}

This section discusses the details and design of the sampling program. Subjects being addressed include sampling parameters, sampling activities, sampling proceoures, and data quality.

7.2.1.1 Objectives. The objectives of the waste sampling and analysis plan are as follows:

- Determine whether building surfaces, the concrete floor, and the outside storage areas contain dangerous waste constituents as defined. by WAC $173-303$ 
- Identify and quantify the specific dangerous waste constituents (if any) present using methods outlined in SW-846 (EPA 1986). If any other methods are used, the method will be referenced and submitted to Ecology

- Determine whether near surface soils (no deeper than 3 feet) underlying the 303-K Storage Facility are contaminated above action levels as a result of operations at the $303-K$ Storage Facility

- Evaluate sample analyses data to determine initial actions and closure status.

\subsubsection{Analytical Parameters. Analytical parameters and methods are based} on knowledge of the operations and contents at the 303-K Storage Facility. A plan was developed to determine the presence of potentially dangerous constituents from chemicals used and waste stored at the 303-K Storage Facility.

A list of the potential contaminants used and stored at the 303-K Storage Facility, the initial action levels, and the analytical method for each constituent are provided in Table 7-1.

As discussed in Chapter 6.0, the soil samples from the 303-K Storage Facility will be analyzed for the constituents listed in Table 7-1. These results will be compared to the action levels, which are the sitewide background threshold concentrations and health-based standards for soil. The initial action levels for samples of concrete and asphalt are LOQ for inorganic and organic constituents.

7.2.1.3 Sampling Activities. Once the building area and the outside storage areas have been decontaminated (Section 7.4), sampling activities will be conducted in the 303-K Storage Facility as follows:

- Core the concrete floor and the concrete and asphalt pads and collect soil samples to a maximum depth of 3 feet in areas with pathways (cracks, expansion joints, etc.) to the soil

- Collect concrete core samples from the floor, walls, and ceiling

- Collect core samples from outside storage pads

- Collect soil samples up to a depth of 3 feet in the outside gravel storage area.

7.2.1.4 Sampling Procedures. Sampling procedures to be used for determining whether chemical waste has contaminated the building, outside storage areas, and the associated soils are described in this section. Sampling procedures will be conducted in conformance with environmental investigation instructions (EII) Environmental Investigations and Site Characterization Manual (WHC 1988) and pertinent EPA guidelines where these exist. 
Areas to be randomly sampled will be divided into 1-square meter grids, and 5 percent of the gridded locations will be sampled. A sample will be taken at the center of each randomly selected l-square meter location. In addition to the random samples, some authoritative samples will be obtained from areas of higher potential contamination (e.g., the floor trench and the soil beneath potential pathways in the floor or pads).

7.2.1.4.1 Floor and Outside Storage Pads. Samples will be taken at gridded locations on the concrete floor and outside on the concrete and asphalt storage pads (Figures 7-2 and 7-3). In addition to the random samples, two authoritative samples will be obtained in the drainage trench near the drain (Figure 7-4). Concrete and asphalt samples will be obtained by coring.

A coring device will be used to obtain a concrete or asphalt core sample. The coring device will employ a 2-inch-diamond bit and use distilled water as a cutting lubricant to minimize dust generation. As little water as necessary will be used to obtain the samples. The core samples will be 1 to 2 inches long. Any waste generated by the sampling process will be handled in the same manner as the coring conducted to sample the soil beneath the concrete (Section 7.2.1.4.3).

Soil samples from the gravel pad will be obtained as described in Section 7.2.1.4.3.

7.2.1.4.2 Concrete Walls and Ceiling. The interior concrete walls and ceiling will be core sampled. The interior walls and ceiling will be divided into 1-square meter grids and 5 percent of the squares will be sampled (Figures 7-5 through 7-7). The samples will be obtained and analyzed in the same manner as described for the floor and pads (Section 7.2.1.4.1).

7.2.1,4.3 Solis. Coring of concrete and asphalt will be conducted as a means of accessing the soil beneath. This will be done at locations where potential pathways to the soil exist.

A coring device will cut the core from each selected location. The coring device will employ a 6- to 12-inch outside-diameter (0D) diamond bit that uses a minimum amount of distilled water as a cutting lubricant to minimize dust generation. No organic-based lubricant will be used. Appropriate measures will be taken to control dust during this operation, including the use of temporary site enclosures and air filtration.

An industrial-size shop vacuum will be used to remove excess water from around the core. This will be done to minimize surface contamination flowing into the underlying soil. The waste water from within the shop vacuum will be emptied into a new 17-H open-headed 55-gallon drum and will be stored at the 303-K Facility until designated according to procedures. The coring device will be decontaminated between samples in accordance with procedures outlined in EII 5.4, "Field Cleaning and/or Decontamination of Equipment" or in EII 5.5, "1706 KE Laboratory Decontamination of RCRA/CERCLA Sampling Equipment" (WHC 1988). All decontamination fluids will be containerized with the waste water. 
Concentrations of inorganic constituents added to the soil by sorption from an effluent containing even drinking water levels of these constituents are greatest in the upper few millimeters, and decrease with increased thickness of the soil column. Because of the well-known process of sorption (Pendias and Pendias 1984; Routson et a1. 1979; Conway 1982; Freeze and Cherry 1979), any contamination remaining in the soil would be the result of equilibrium reactions and/or irreversible sorption. In either case, residual contamination mostly would be concentrated in the uppermost part of the soil column, with rapidly decreasing concentrations downward. Therefore, the uppermost part of the soil column is most likely to contain contamination if present.

Any contamination of the soil by organic solvents associated with the 303-K Storage Facility is likely to be small and, if present, dominate in the uppermost part of the soil column. The only pathway for the organic contaminates to the soil would have involved the transport of a small fraction of any spill (no spills were reported) to the soil through cracks in the concrete floor. Because of the relatively small amount of potential contamination, the general lack of evaporation under the concrete floor, and the tendency for such small amounts to be retained in the soil, any potential organic contamination from this source is most likely to be present in the upper part of the soil column.

Because the potential contamination from the 303-K Storage Facility would remain in the upper part of the soil column, a maximum sampling depth of 3 feet would be adequate. During soil sampling, samples will be obtained from the surface, at 1 foot, 2 feet, and 3 feet. The sample will consist of soil 1 inch above and 1 inch below the sampling point. For example, the sample at the 2 foot mark would include the section of dirt that was 1 foot, 11 inches to 2 feet, 1 inch below the surface.

Soil samples from the gravel area and beneath the storage pads will be considered worst-case contamination. If no contamination is detected in the near surface soil samples, the $303-K$ storage Facility will be considered to have contributed no contanination to the subsurface below 3 feet.

The soil samples will be analyzed for the contaminants listed in Table 7-1.

A precleaned, 4-inch 00 hand-operated soil auger will be $p l$ aced at each sampling location and soil will be removed to a total depth of 3 feet. If access to the sampling location is restricted, a small shovel or trowel could be used. Samples from the hole will be placed immediately in a laboratoryprepared sample container to minimize loss of volatiles and will be stored on ice in a cooler at $4{ }^{\circ} \mathrm{C} \pm 2{ }^{\circ} \mathrm{C}$. The soil auger, as well as all sampling equipment, will be decontaminated in accordance with procedures outlined in EII 5.4, "Field Cleaning and/or Decontamination of Equipment" (WHC 1988). The equipment will be cleaned before use at each sample location.

Excess soil that is removed from each hole will be containerized in a 17-H open-headed 55-gallon container until results of the soil analyses are received. The container will be stored at the 303-K Storage Facility until 
1 designated according to onsite procedures. Each hole in the floor or pad will

2 be sealed with concrete or asphalt after sampling is completed.

7.2.1.5 Sampling Locations. Areas to be sampled have been divided into eight sections, consisting of the four walls, the floor, the ceiling, outside storage pads, and the gravel area. Sampling locations have been selected randomly except where authoritative sampling is warranted in areas of potential contamination. Each of the eight sections has been gridded to facilitate the selection and identification of random sample locations. A minimum of 5 percent of the gridded area for each section will be sampled. The use of random-sampling strategy will ensure that data obtained will be representative of the population from which the samples were taken. Areas of potential contamination were selected for authoritative sampling because of the higher potential for contamination. The randomly selected sampling locations are included in Appendix B. The number and location of each type of sample is presented in Table 7-2. Each section is discussed in the following sections with respect to sample locations.

7.2.1.5.1 Building Walls. The sampling locations for the north wall are shown in Figure 7-5. There are 24 1-square meter grids. Two locations will be sampled.

The sampling locations for the south (inside) wall are shown in Figure 7-5. There are 24 1-square meter grids. Two locations will be sampled.

The sampling locations for the east wall are shown in Figure 7-6. Only the northern portion of the building was used for storage of mixed waste. There are 24 1-square meter grids. Two locations will be sampled.

The sampling locations for the west wall are shown in Figure 7-6. There are 24 1-square meter grids. Two locations will be sampled.

7.2.1.5.2 Ceiling. The ceiling will be gridded and sampled because of the possibility of contamination caused by the billet fires. The sampling locations are shown in Figure 7-7. There are approximately 641 -square meter grids. Three locations will be sampled.

7.2.1.5.3 Outside Storage Areas. The sampling locations for the outside storage areas are shown in Figure 7-3. The two concrete-covered areas contain approximately 671 -square meter grids. A total of five locations will be core sampled. In addition, areas where potential pathways are visible will be sampled by collecting a soil sample under the pad (Figure 7-4). These samples will be analyzed for contaminants listed in Table 7-1.

The asphalt portion of the outside storage area also will be gridded for core samples (Figure 7-3). The asphait-covered areas contain approximately 2541 -square meter grids and 13 locations were selected for sampling. These samples will be anaiyzed for contaminants listed in Table 7-1.

The sampling locations for the graveled portion of the outside storage area are shown in Figure 7-3. This portion of the area has been divided into

931213.1520 
1 approximately 91 1-square meter grids, and five locations were selected for

2 sampling. A hand auger will be used to sample the soils to a depth of 3 feet.

3 Samples will be taken from the surface at 1 foot, 2 feet, and 3 feet. The

4 samples will be analyzed for the contaminants listed in Table 7-1.

The soil beneath the storage pads and building floor will be authoritatively sampled in areas of potential pathways (cracks, expansion joints). The potential pathways will be documented in a scale drawing before sampling. This will ensure that all potential pathways, with the exception of hairline cracks (cracks that do not penetrate beyond the surface), are sampled. The sampling location on each potential pathway will be selected to ensure that the most likely point of soil contamination will be sampled. The sample location indicators (most likely to allow for infiltration of contaminants) are the widest portions of the potential pathway, the portions of the pathway with the lowest elevation, and any areas on the pathway that are stained. At least 5 percent of the length of each potential pathway will be sampled (once every 20 feet). Each separate potential pathway will be sampled at least once. Soil samples will be taken through the core hole in the pad or floor. Samples will be taken from the surface at 1 foot, 2 feet, and 3 feet.

7.2.1.5.4 Floor. Core sampling locations for the trench are shown in Figure 7-4 and the core sampling locations for the concrete floor are shown in Figure 7-2. According to historical records, only the northern portion of the building was used to store dangerous or mixed waste. Three sampling locations within the approximately 64 1-square meter floor grids will be core sampled. The soil beneath cracks in the building floor will be sampled as described in Section 7.2.1.5.3.

7.2.1.6 Data Quality. To ensure quality data, all sampling will be conducted in conformance with onsite procedures (WHC 1988). All laboratory analyses will be performed in accordance with standard EPA methods described in the most recent edition of SW-846 (EPA 1986). The analytical laboratory will submit all analytical and quality assurance/quality control (QA/QC) procedures to the O\&E for approval before samples are analyzed. The EPA guidelines for reporting accuracy, precision, practical quantification limit method detection limits, and limits of quantification specified in the analytical methods will be met.

Quality control of sampling will be ensured by using field duplicates, equipment blanks, trip blanks, and field blanks. Each of these sampln types is discussed in Section 7.2.8. Quality control of records and documentation will be accomplished by following procedures outiined in EII 1.6, "QA Records Processing" (WHC 1989).

Sampling records to be kept on file include field notes, daily memoranda, records of meetings, and axtivities concerning the sampling program, and chain-of-custody records. In addition, QC will be implemented through the recording of field memoranda and field notes. The types of records and documentation required for all samples are described in Section 7.2.8. 


\begin{abstract}
Appendix $F$ contains the quality assurance project plan (QAPjP) for sampling and analysis at the 303-K Storage Facility.

\subsubsection{Modifications to the Waste Sampling and Analysis Plan}

The optimal aspects of sample design are sometimes not achievable because of unanticipated or changing conditions. Factors adversely influencing sampling efforts can inciude equipment malfunction or breakdown, improper equipment, physical barriers to coring equipment, and overly optimistic evaluation of other physical conditions at sites with no previous history of dangerous waste characterization. When changes to the planned activity are necessary, the changes will be recorded in the field logbook along with circumstances requiring the action. The field logbook will be reviewed and signed by the project manager daily, as described in EII 1.5, "Field Logbooks" (WHC 1988). This procedure will provide an accurate record of changes and approvals, while allowing sampling to proceed safely while maintaining efficient manpower and equinment usage. When deviations from an EII are required, procedures outlined in EII 1.4, "Instruction Change Authorization" (WHC 1988) will be followed. In addition, any changes to the closure plan will be in accordance with WAC 173-303.
\end{abstract}

\title{
7.2.3 Data Evaluation Process
}

Analytical results from the 303-K Storage Facility sampling will be compiled, evaluated, and summarized in the following manner:

- Conduct the statistical evaluation of the analytical data as described in Section 7.2.4

- Prepare summary statistics for constituents as described in Section 7.2.4

- Test the significance of the location and/or depth effects of analytical results

- Compare the sample results to the action levels.

\subsubsection{Statistical Treatment of Data}

All data collected will be analyzed and tabulated for evaluation using the methods described in SW-846 (EPA 1986). Other guidance documents and statistical references may be used where applicable [e.g., Barth and Mason 1984 and Statistical Analysis of Ground Water Monitoring Data at RCRA Facilities, Interim Final Guidance (EPA 1989C)]. Laboratory data will be provided to Ecology upon completion of sampling and analysis. Data for individual constituents will be summarized and will include the following information:

- Number of less than detection limit values

- Total number of values 
- Mean values

- Standard deviation

- Accuracy

- Coefficient of variation

- Method detection limit values

- LOQ values

- Representative method precision

- Median value

- Minimum value

- Maximum value.

The data will be interpreted by qualified scientists and statisticians. Data evaluation will be based on statistical criteria and professional judgment as appropriate.

\subsubsection{Assessment of Data Reliability}

Data reliability will be assessed by evaluating the sample handling and analysis $Q C$. Sample handling QC will be evaluated by reviewing field documentation and results of $Q A$ samples to establish that sampling error was minimized. The review will be conducted to verify that decontaminated equipment was used, cross-contamination was minimized, samples were preserved properly, and that the chain of custody of the samples was not broken.

Analytical data received from any sampling performed at the 303-K Storage Facility will be scrutinized against the QC report provided by the contractor laboratory to assess the reliability of the results. Both organic and inorganic cilemical analytical results will be checked as follows:

- Inorganic chemical analysis laboratory assessment

- Holding times are acceptable

- Contractor's detection limits are below those required by the EPA

- Laboratory blanks and replicates are within established QC 1 imits

- Sample spike recoveries are within QC limits

- Organic chemical analysis laboratory assessment

- Holding times are acceptable

- Instrument detection limits, blank recoveries, surrogate recoveries, and spike recoveries are within EPA established QC limits.

\subsubsection{Reporting}

After completion of the sampling effort, verification documents will be provided for actual sample locations, number of samples, and specific methods used for collection if different from those provided in this waste sampling and analysis plan. Data received from the laboratory will be reviewed, analyzed, and summarized statistically. The results will be used to provide further closure evaluations. 


\subsubsection{Sampling Equipment, Containers, and Preservation}

This section describes the equipment, containers, and preservation methods used for sample collection at the 303-K Facility.

7.2.7.1 Sampling Equipment. Sampling equipment to be used will be appropriate to the spectrum of media that might be encountered. The media to be sampled consist of the following:

- Concrete

- Soils

- Asphalt.

The following are examples of the types of sampling equipment that might be used during the various phases of the investigation.

\begin{tabular}{l} 
Concrete/asphalt \\
\hline $\begin{array}{l}\text { Concrete/asphalt } \\
\text { coring device }\end{array}$
\end{tabular}

Soils/gravel

- Auger

- Split spoon

- Trowel

- Scoop

- Shovel

An auger and split spoon will be used to collect soil and gravel samples if site conditions permit. Otherwist, a trowel, scoop, or shovel will be used. The sampling equipment will be constructed of stainless steel or have liners constructed of inert materials.

Additional equipment and supplies will be procured as required to perform the necessary sampling. Equipment could include, but not be limited to, the following items:

- Bore or wire brushes

- Stainless steel mixing bowls

- Sized, heavy-duty plastic bags

- Stainiess steel spatulas, scoops, and spoons

- Adhesive tape

- 100-foot steel tape, 12-foot steel tape

- Compass

- Indelible marking pens or pencils

- Hammer/sledgehammer

- Ice chests and ice

- Security tape, flagging

- Gloves of material suitable for anticipated hazards

- Field radio

- Rags

- Appropriate drawings and maps

- Tags

- Plastic sheeting

- Water containers 
- Extra glass and plastic bottles (in case of breakage or contamination)

- Industrial-size shop vacuum

- Teflon sheets

- Concrete.

7.2.7.2 Sample Containers and Preservation. Sample containers will be chosen based on their compatibility with the samples, resistance to leaking or breakage, ability to seal tightly, and capacity to hold the required volume for an optimum sample. Containers for collecting and sorting samples will be made of high-density plastic or glass appropriate for the constituents to be analyzed. The containers will have tight, screw-type lids with Tefion cap liners for glass bottles.

A11 samples will be packaged according to EII 5.11, "Sample Packaging and Shipping" (WHC 1988), placed in an ice chest, and cooled to $4{ }^{\circ} \mathrm{C} \pm 2{ }^{\circ} \mathrm{C}$ immediately after collection. Soil and sediment sample containers will be those specified in EII 5.2, "Soil and Sediment Sampling" (WHC 1988). Because the samples will be collected from radiation zones, the samples must be checked by a radiation protection technologist before being removed from the site, according to onsite operating procedures and the site-specific health and safety plan (HASP) to be developed. For samples collected from radiation zones, a dose assessment will be conducted for use in developing an as low as reasonably achievable (ALARA) plan for sampling activities. The assessment will be conducted in a manner that will not compromise the validity of the samole. All deviations from SW-846 protocols (EPA 1986), including sample size, will be documented with a justification for the deviation.

\subsubsection{Sampling Quality Control}

The required $Q C$ procedures will be followed to adequately control sampling activities. The various QC procedures are described in the following sections.

7.2.8.1 Field Quality Control. Field QC will be accomplished by various sampling duplicates and blanks, as described in the following paragraphs. The QC samples will be taken as listed in Table 7-3.

Field duplicate samples will be taken for concrete cores and underlying soils. Duplicate samples are two separate samples collected from the same sampling point and placed into separate containers. The duplicates will indicate the repeatability of the analytical data.

Equipment blanks will serve as a check on sampling device cleanliness. An equipment blank will consist of distilled water that is transported to the site, opened in the field, and poured over or through the sample collection device, collected in a sample container, and returned to the laboratory for analysis. These samples will be collected daily.

"Tefion is a trademark of E. I. duPont de Nemours and Company, Incorporated. 
Trip blanks will identify any possible contamination originating from container preparation methods, shipment, handling, storage, or site conditions. Trip blanks will consist of pure deionized, distilled water in a clean sample container, which will accompany each batch of containers shipped to the field. Trip blanks will be returned unopened to the laboratory for analysis.

Field blanks will consist of pure deionized, distilled water that is transferred to a sample container at the site and preserved with the reagent specified for the analyses of interest. Field blanks will check for possible contamination originating with the reagent or the sampling environment and will be collected daily.

7.2.8.2 Field Logbook. The personnel conducting sampling will maintain an official logbook during the effort, as outlined in EII 1.5, "Field Logbooks" (WHC 1988). The book will be bound and will have consecutively numbered pages. Ali information pertinent to the sampling must be recorded in the logbook in a legible fashion. If changes are necessary, changes will be indicated by a single line drawn through the affected text. The individual responsible for the change will initial and date the entry. Each day's activities or separate sampling episodes must be signed. The logbook will be protected, stored in a safe file or other repository, and retained as a permanent record.

The following types of information will be included in the logbook:

- Site map, sketch, drawing, or other definitive site description

- Locations of all sampling points, including reference points and scale

- Sample method

- Sampling location

- Date and time of collection

- Collector's name

- Number, type, and volume of samples taken

- Identification number for each sample

- Field observations (weather conditions, temperature, wind, wetness, and appearance of sample)

- Laboratory of destination

- Field measurements, including the results of the radiation survey

- Signature of recording personnel. 
The following items could be included in the logbook:

- Name and address of field contact

- Producer of waste

- Type of process

- Type of waste

- Type and/or purpose of sampling

- Sample transportation method

- Photographs of site for field conditions and site location verification.

7.2.8.3 Sample Labels. Labels will be securely attached to each sample to prevent misidentification. Labels can be adhesive labels or tags and will be affixed to the proper sample containers before or at the time of collection. All information will be completed at the time of collection. Indelible pencil or ink must be used. Each label will contain at least the following information:

- Site contractor

- Collector's name

- Date ard time collected

- Sample number.

7.2.8.4 Sample Seals. Sample seals will be used to prevent and/or detect tampering with samples between the time of collection and the beginning of analysis. Seals will be applied to the sample containers before the containers leave the sample location. The seals will be attached so the seal must be broken to open the container.

7.2.8.5 Chain-of-Custody Records. To ensure the integrity of the samples from collection through analysis to final disposition, documentation will be necessary to trace sample possession and handling. This documentation generally takes the form of a record providing a history of all the people having custody of the sample, including the following situations when a sample is:

- In a person's physical possession

- In view of a person

- Secured by an individual to prevent tampering

- Placed in an area restricted to authorized personnel only. 
A chain-of-custody record will be completed and must accompany all samples from collection to analysis. Multiple copies will be required, and at least one copy must be maintained by the sampling supervisor. The following information will be included:

- Contractor

- Sample numbers

- Date and time collected

- Sample type

- Number of containers

- Collector's signature

- Signature of person receiving possession

- Inclusive dates of possession

- Condition of samples upon receipt.

Procedures outlined in EII 5.1, "Chain of Custody" (WHC 1988) will be followed.

7.2.8.6 Sample Analysis Request. The sample analysis request form is designed to accompany the samples to the laboratory and to designate the analyses to be performed on each sample. This form also provides a check to ensure that all samples have been received and that correlation between sample analysis and sample number is finalized and complete.

This form should include the following information:

- Contractor

- Company contact

- Collector

- Sample number

- Sample type

- Analysis requested

- Data and time collected

- Laboratory sample custodian.

Procedures outlined in EII 5.1, "Chain of Custody," and 5.2, "Soil and Sediment Sampling" (WHC 1988) will be followed.

7.2.8.7 Laboratory Receipt and Logging of Sample. In the laboratory, a sample custodian will be assigned to receive the samples. Upon receipt of a sample, the custodian will (1) inspect the condition of the sample and the sample seal, (2) verify the information on the sample label and seal against that on the chain-of-custody record, (3) assign a laboratory number, (4) $10 \mathrm{~g}$ in the sample in the laboratory logbook, (5) store the sample in a secured sample storage room or cabinet, which is adequate for the preservation requirements of the sample, and (6) report missing or damaged samples immediately. The results of the radiation survey data will be provided to the laboratory performing analyses of those samples exhibiting activity greater than 200 counts/minute. 
1 7.2.8.8 Sample Disposition. At the certified completion of all analyses, the 2 samples will be returned to the collector. In no case will the samples be 3 retained longer than 3 years unless specifically designated by the cognizant 4 engineer.

7.2.8.9 Decontamination. This section discusses personnel, equipment, and sample containers decontamination procedures.

7.2.8.9.1 Personnel Decontamination Procedures. A decontamination area will be established near the 303-K Storage Factlity and upwind of sampling activity. If it is not possible to provide a decontamination area upwind and the wind is a problem, sampling will not occur that day. Procedures for personnel decontamination will be provided in a HASP. In addition, the 303-K Storage Facility-specific HASP will be prepared before sampling and added to the closure plan at that time. This plan (titled a hazardous waste operation permit) will be prepared in accordance with EII 2,1, "Preparation of Site Specific Health and Safety Plans" (WHC 1988).

7.2.8.9.2 Equipment Decontamination. Extreme care is necessary in field sampling to ensure that there is no cross-contamination of samples by sampling equipment. To prevent this source of contamination, freshly cleaned or disposable sampling tools will be used. When equipment must be reused in the field, it will be cleaned as thoroughly as practical in accordance with EII 5.4, "Field Cleaning and/or Decontamination of Equipment" (WHC 1993). Decontamination wash water will be placed in 55-gallon containers and solidified with a clay mixture for disposal as solid low-level radioactive or mixed waste. Whenever possible, equipment will be cleaned in the laboratory according to procedures specified in EII 5.5, "1706 KE Laboratory Decontamination of RCRA/CERCLA Sampling Equipment" (WHC 1988).

7.2.8.9.3 Sampling Container Decontamination Procedures. Containers will be purchased precleaned from the factory and maintained under strict chain of custody to preserve the integrity of the samples from collection through disposal. Sample containers will be disposed of after analysis.

\subsubsection{Analytical Procedures}

Analyses of all constituents except uranium will be performed by the laboratory in accordance with EPA requirements in SW-846 (EPA 1986). The EPA specified detection limits are goals; the actual detection limits will be presented in the analytical certification reports. One of two methods will be used for uranium analysis (Table 7-1). The SCINTREX UA-3 laser method may be better suited to detect uranium than the EPA method that detects oniy gross alpha and beta.

7.2.9.1 Concrete and Asphalt Inorganic Analysis Methodology. Ecology guidelines for sampling inorganics in concrete and asphalt will be followed.

49 The preferred concrete inorganic analysis methodology involves a two-part

"SCINTREX is a trademark of SCINTREX, InC. 
1 process. The initial part is hot acid digestion (SW-846 Method 3050), with

2 total metals analysis using inductively coupled plasma (ICP-AES) atomic

3 emissions spectroscopy (SW-846 Method 6010, EPA 1986). This part indicates

4 which metals are present in the concrete matrix in sufficient quantities to

5 present a potential threat to the environment. The second part, which is

6 performed on a second test portion of sample material, is the toxic

7 characteristic leachating procedure (40 CFR 261, Appendix II) followed by

8 total metals analysis using ICP-AES (SW-846 Method 6010). This part

9 determines if any of the metals present can leach out of the concrete matrix

and pose a threat to human health and the environment.

Both parts will be conducted with a full analysis for all constituents of concern. This will ensure that all potential inorganic contamination constituents are included and identified rather than only for those that show high concentrations in the initial part.

\subsubsection{Concrete and Asphalt Organic Analysis Methodology. There is not an} established analytical method for volatile organics analysis (VOA) of concrete or asphalt samples. The most promising method is that for soils and sediments as given in SW-846 Method 8260A (EPA 1986). However, this method is undocumented for concrete or asphalt analysis. The problems and uncertainties associated with using Method 8260A for concrete and asphalt VOA can be overcome with a modified procedure for collecting the VOA contamination from a sample of concrete or asphalt. The collection methodology desorbs the organic constituents from the concrete or asphalt into high purity water using agitation provided by an ultrasonic bath. The water is then analyzed for volatile organics by gas chromatography/mass spectroscopy (GC/MS) using a modified procedure based on SW-846 Method 8260A (EPA 1986).

\subsubsection{Laboratory Quality Control}

The contractor laboratory will ensure the integrity and validity of test results through implementation of an internal QC program. The program will meet the QC criteria of SW-846 (EPA 1986). A system of reviewing and analyzing the results of these samples will be maintained to detect problems caused by contamination, inadequate calibrations, miscalculations, improper procedures, or other factors. Standard methods will be used whenever possible. Alternative methods that are developed or adapted will be tested and completely documented per the requirements of SW-846 (EPA, 1986). ATi methods and method changes will be approved by an onsite contracts representative.

The QC procedures for dangerous waste analyses will include [as appropriate to each analysis and as specified in Section 1.2 of SW-846 (EPA 1986)] evaluation of blanks, duplicates raridom matrix spikes (for 10 percent of the samples), internal standards, surrogates, and standard calibration curves. Spikes will be added in amounts depending upon the amount of analyte present in the sample. The QC procedures specific to individual methods will be detailed in the laboratory's documented analvtical procedures and $Q C$ data included with each batch of samples analyzed. Appendix F contains the QAPP. 


\subsubsection{Site Safety}

This section discusses the site-specific health and safety plan, contamination control and waste handling, personnel training, and standard safety procedures.

7.2.11.1 Health and Safety Plan. A HASP is required for all dangerous waste sampling sites. HASP is intended to specify information pertinent to field assignments and to be a guide in unusual situations or emergencies. A sitespecific version of the general RCRA/CERCLA investigation health and safety manual will be developed for use in sampling at the 303-K Facility. The site-specific HASP will be prepared in accordance with EII 2.1, "Preparation of Site-specific Health and Safety P1ans" (WHC 1988).

7.2.11.2 Contamination Control. Because sampling is to be undertaken within a radiological control area, standard onsite radiation work procedures will be followed. In addition, the following activities will be performed.

- Modification to personnel decontamination procedures--All modifications to decontamination procedures will be approved by the field team leader (cognizant engineer) and the site safety officer. Modifications will be recorded in the appropriate logbooks.

- Disposal procedures--Excess sample material will be containerized in a 17-H open-headed 55-gallon container. Rinse waters also will be containerized. Disposal procedures of unknown or suspect waste materiais will be formed in accordance with EII 4.2, "Interim Control of Unkno Dected Hazardous and Mixed, and Radioactive Waste" (WHC 1988

Waste materials are designated as unknown waste when:

- Criteria for suspected hazardous waste are not met

- Field readings are suspect.

Waste II iterial will be designated as suspected hazardous waste based on process knowledge of material that is known to have been discharged to the area under investigation, provided the following:

- Direct instrumentation reading of organic vapor is in excess of 10 parts per million above background levels

- $\mathrm{pH}$ is less than 3 or greater than 12 .

Articles such as protective clothing that have been soiled with potentially contaminated materials will be temporarily placed in containers.

In accordance with WAC 173-303-200(2) and EII 4.2 (WHC 1993), the 55-gallon containces will be stored in satellite accumulation areas. When waste is generated, the major risk(s) will be marked on the containers. Sampling and analysis will be conducted as needed to complete waste designation. When a container is full it will be marked with the accumulation data (drum fill date). Then the container will either be moved to a less-than-90-day accumulation area 
DOE/RL-90-04, Rev. 2

$12 / 15 / 93$

or shipped directly to a different RCRA permitted treatment/storage/disposal facility within 72 hours of filling the drum. If a less-than-90-day accumulation area, the waste will be moved to a different RCRA permitted treatment/storage/disposal facility within 90 days of the accumulation date. If hazardous contamination is not found, materials will be laundered or disposed of according to onsite procedures that are written in accordance to WAC 173-303, DOE orders, and 40 CFR 261.

7.2.11.3 Personnel Training. All personnel involved with the closure activities at the $303-K$ Storage Facility will receive a minimum level of dangerous waste training as follows.

- Managers and supervisors are responsible for supervising, coordinating, and directing the closure activities and personnel.

- Metal operators and decommissioning and decontamination workers are responsible for packaging and handling dangerous waste (both nonradioactive and radioactive material).

- Samplers are responsible for obtaining the samples.

- Health physics technicians are responsible for surveying for radiological contamination.

- Crafts personnel are responsible for specialized work. The various crafts include carpenters, electricians, ironworkers/riggers, heavy equipment operators, crane operators, millwrights, pipefitters, and painters.

Table 7-4 contains a matrix that relates job categories to the individual training course. Appendix E contains brief descriptions of the training courses, including descriptions of the target audience, instructional technique, evaluation method, length of course, and frequency of retraining.

7.2.11.4 Standard Safety Procedures. The following safety procedures will apply each time personnel make a site entry for sampling purposes.

- No personnel will be at the site without a designated 'butdy'.

- One of the people entering the site will be designated to be in charge.

- Personal protective equipment will be worn as specified. Approved deviations will be entered in the field logbook and signed by the field team leader (cognizant engineer) and the site safety officer.

- Field work will be planned before the site is entered.

- Equipment needed for work will be inventoried and inspected before the site visit to ensure that all equipment is present and in operable condition. 


\subsection{REMOVAL OF CONTAMINATED MATERIAL AND WASTE RESIDUES}

Waste remaining in the building and in the outside storage areas at the commencement of closure activities will be removed. General housekeeping cleanup procedures will be followed to remove any remaining waste residues.

\section{T.4 DECONTANIMATION AND DISPOSAL OF BUILDING AND CONCRETE PAD}

The building's interior will be decontaminated using some combination of the following techniques:

- Damp wipe downs

- Vacuum-assisted mechanical removal

- Sandblasting

- High-pressure steam and suction.

It is anticipated that a majority of the decontamination work can be accomplished using damp wipe downs and vacuuming. However, the actual method of decontamination will be specified in a decommissioning work plan, which will address each area of concern (sandblasting or scabbling might be necessary for some floor areas, while this method might be inappropriate and unnecessary for wall areas). Decontamination waste will be tested for the constituents in Table 7-1 to determine the appropriate method of disposal.

A 'decommissioning work plan' is a generic term for the implementation procedure used to provide specific field direction to workers actually performing the decontamination and demolition. The general decontamination information is included in Sections 7.3, 7.4, and 7.5. The actual decommissioning work plan will specify sufficient detail for field implementation of the items addressed in these sections. The decommissioning work plan will be included as an appendix in the closure plan. This will take place just before the work begins.

Sampling (as described in Section 7.2) will be conducted following the cleaning process to determine the effectiveness of the cleaning procedure and the appropriate remedial options.

The analytical results of the concrete and asphalt core samples will be evaluated to determine if the building and storage pads can be used for lessthan-90-day storage. If portions of the building and storage pads do not meet the action levels presented in this closure plan, those portions will be removed and disposed of based on the following criteria.

- If the material is a dangerous waste (only), the material will be transported and disposed of offsite at a permitted treatment, storage, and/or disposal (TSD) facility. 
DOE/RL-90-04, Rev. 2

2

3

4

40

46

- If the material is mixed waste, the material will be transferred to the Central Waste Complex for interim storage and future treatment or disposal. Requirements for solid mixed waste packaging, storage, and disposal (WHC 1991) will be followed when preparing waste for storage and/or disposal.

- If the material is not dangerous but is low-level radioactive waste, the material will be disposed of onsite in the 200 Area.

With the exception of an imminent health threat, all soil remediation will take place under the CERCLA remedial action process for the 300-FF-3 operable unit.

\subsection{OTHER ACTIVITIES REQUIRED FOR CLOSURE}

An interim cover might be placed over the building location if the building and outside storage pads are removed and if WAC 173-303 contaminants are left in place, pending remediation of the 300-FF-3 operable unit. The cover material will depend on the results of the soil samples but could consist of packed clay, asphalt, concrete, a synthetic liner, fixative spray, or a combination of these materials. Reclamation might be justified to control dust, erosion, surface water run-off, and to promote postciosure usage. Site restoration might include backfilling disturbed soil areas with noncontaminated native soil, compaction, and grading (Chapter 8.0, Section 8.2).

Depending on the surface area, method, material, and location of areas to be decontaminated, a greenhouse might be necessary to control the spread of low-level radiological and dangerous contaminants. This greenhouse will provide a negative air pressure (via HEPA filter-equipped exhauster), airlock entry and exits, and other attributes similar to an asbestos work enclosure described by EPA in Asbestos Waste Management Guidance (EPA 1985).

All equipment used during closure activities will be decontaminated or disposed of according to the following:

- EII 4.2, "Interim Control of Unknown, Suspected Hazardous and Mixed, Radioactive Waste" (WHC 1988)

- EII 5.4, "Field Cleaning and/or Decontamination Equipment"

- EII 5.5, "1706 KE Laboratory Decontamination of RCRA/CERCLA Sampling Equipment" (WHC 1988).

\subsection{SCHEDULE OF CLOSURE}

Closure of the 303-K Storage Facility will begin on notification by Ecology of closure plan approval. Closure will proceed according to the schedule presented in Figure 7-8. 


\subsection{AMENDMENT OF PLAN}

The closure plan for the 303-K Storage Facility will be amended whenever changes in operating plans or design affect the closure plan, whenever there is a change in the expected year of closure, or if, when conducting closure activities, unexpected events require a modification to the closure plan. The closure plan will be modified in accordance with WAC 173-303-610(3). This plan may be amended any time before certification of final closure of the 303-K Storage Facility.

If an amendment to the approved closure plan is required, the DOE-RL will submit a written request to Ecology to authorize a change in the approved plan. The written request will include a copy of the closure plan amendment for approval.

\subsection{CERTIFICATION OF CLOSURE}

Within 60 days of closure of the 303-K Storage Facility, the DOE-RL will submit to Ecology a certification of closure. The certification will be signed by both DOE-RL and an independent professional engineer. The certification will state that the 303-K Storage Facility has been closed in accordance with the approved closure plan. The certification will be submitted by registered mail or an equivalent delivery service. Documentation supporting the independent professional engineer's closure certification will be retained and furnished to Ecology upon request.

The DOE-RL and the independent professional engineer will certify with a document similar to Figure 7-9. 


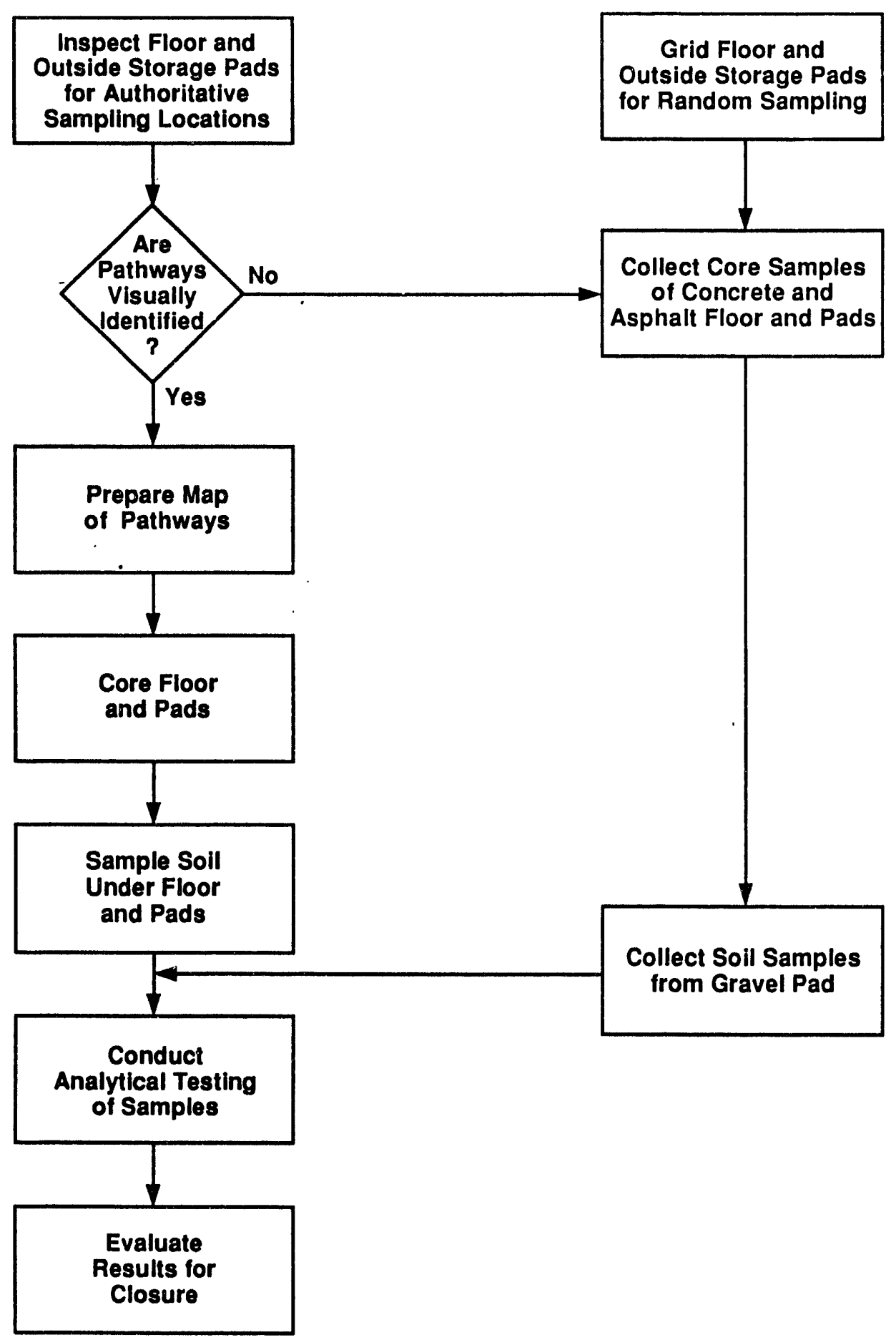

GENM092793-B

Figure 7-1. Waste Sampling and Analysis Flowchart. 
DOE/RL-90-04, Rev. 2

$12 / 15 / 93$

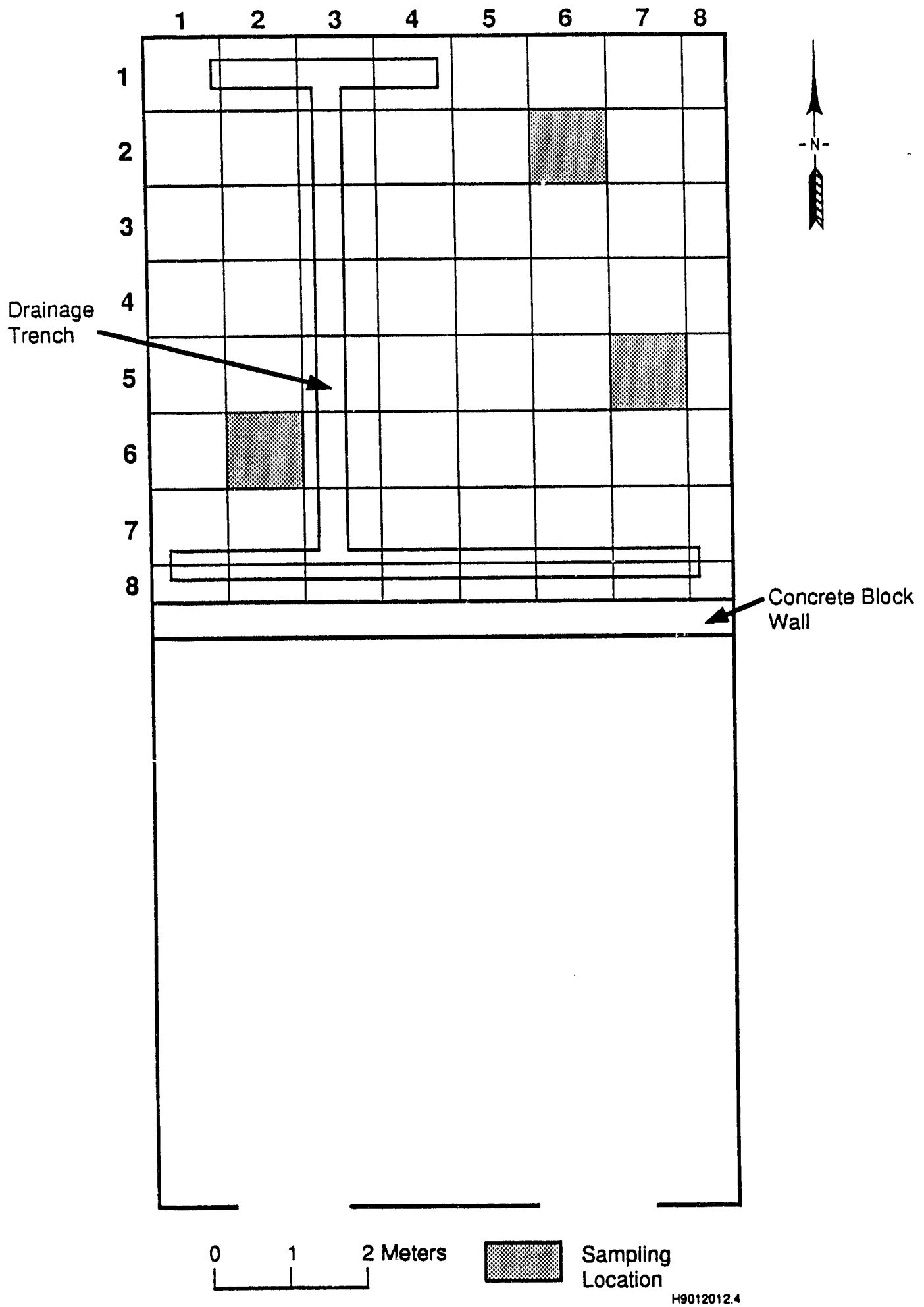

Figure 7-2. 303-K Storage Facility, Floor Core Sampling Locations. 
DOE/RL-90-04, Rev. 2

12/15/93

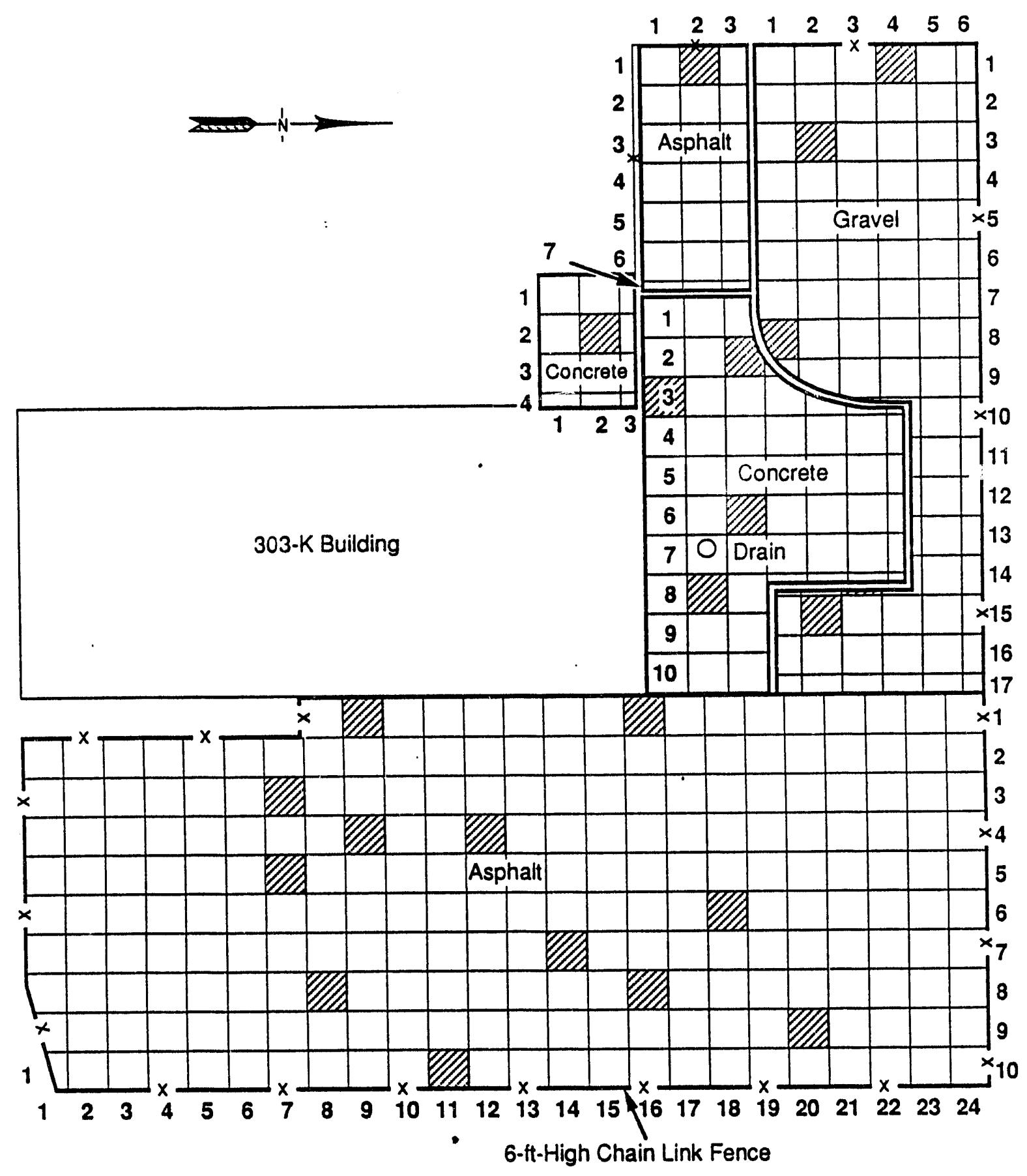

0

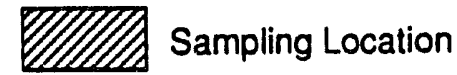

- $x$ - Fence

59004084.1

Figure 7-3. 303-K Storage Facility, Sampling Locations on Outside Storage Pads and in Gravel Area. 


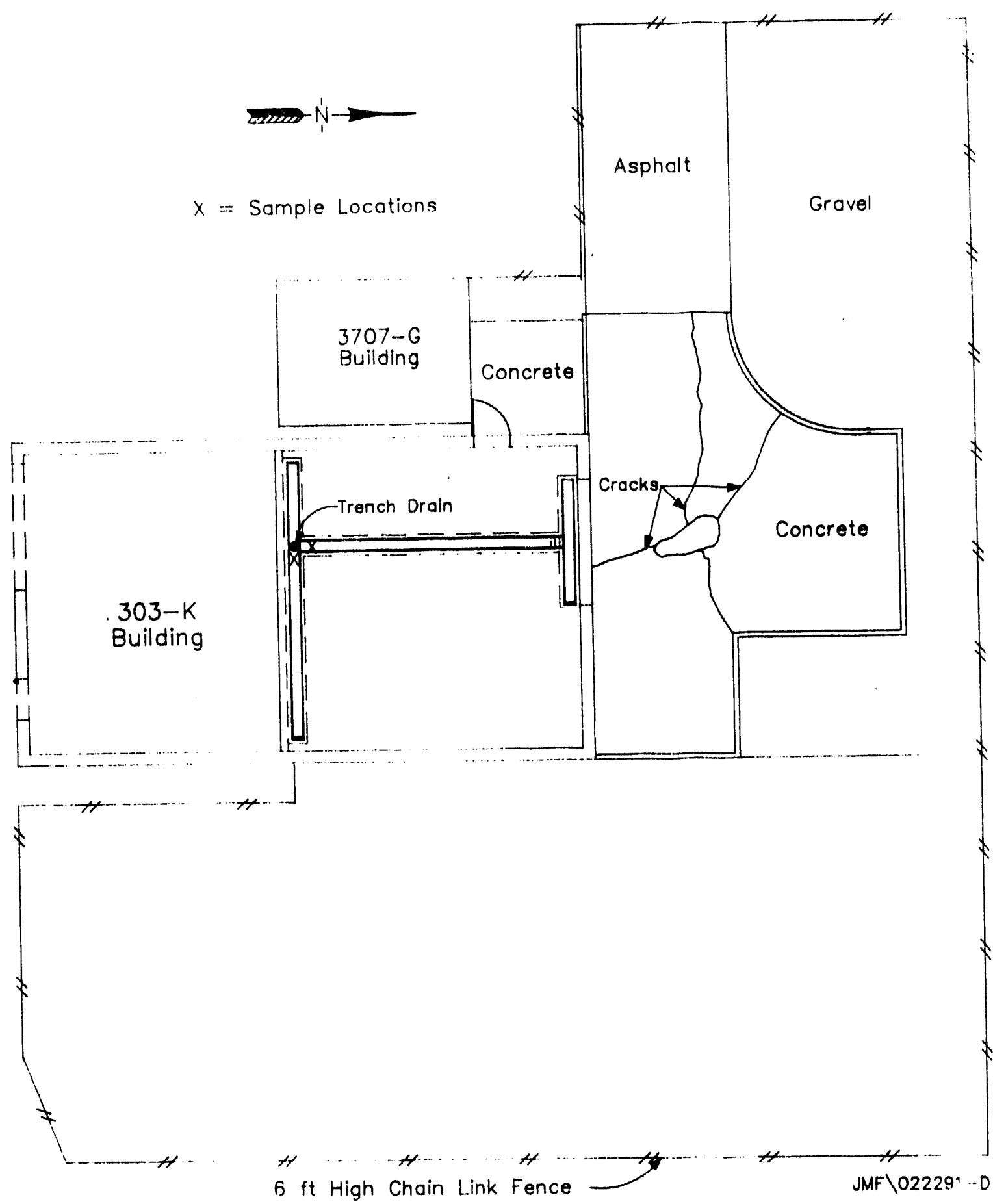

Figure 7-4. 303-K Storage Facility Sampling Locations in Areas of Potential Contamination. 


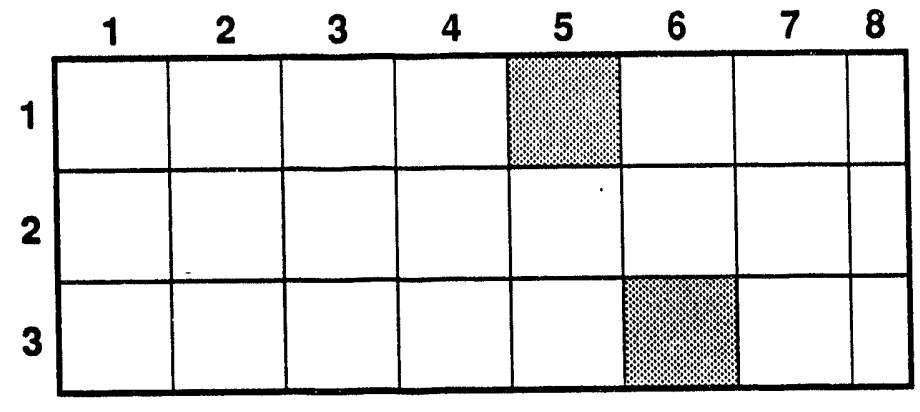

South Wall (Inside)

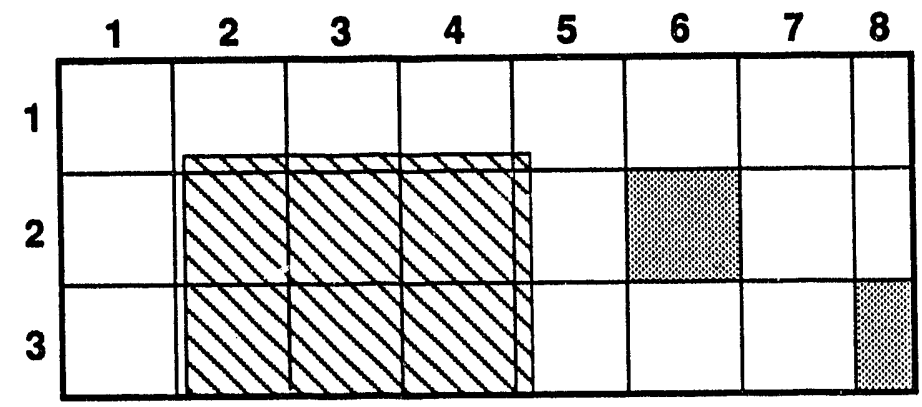

North Wall
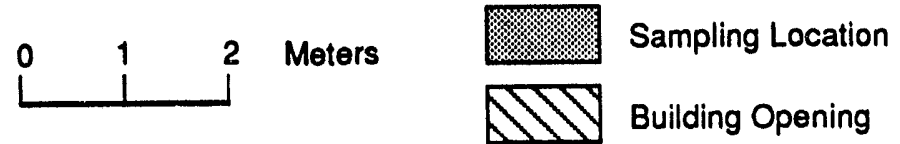

SPO12012.8

Figure 7-5. 303-K Storage Facility, South Wall (Inside) and North Wall Sampling Locations. 
DOE/RL-90-04, Rev. 2

$12 / 15 / 93$
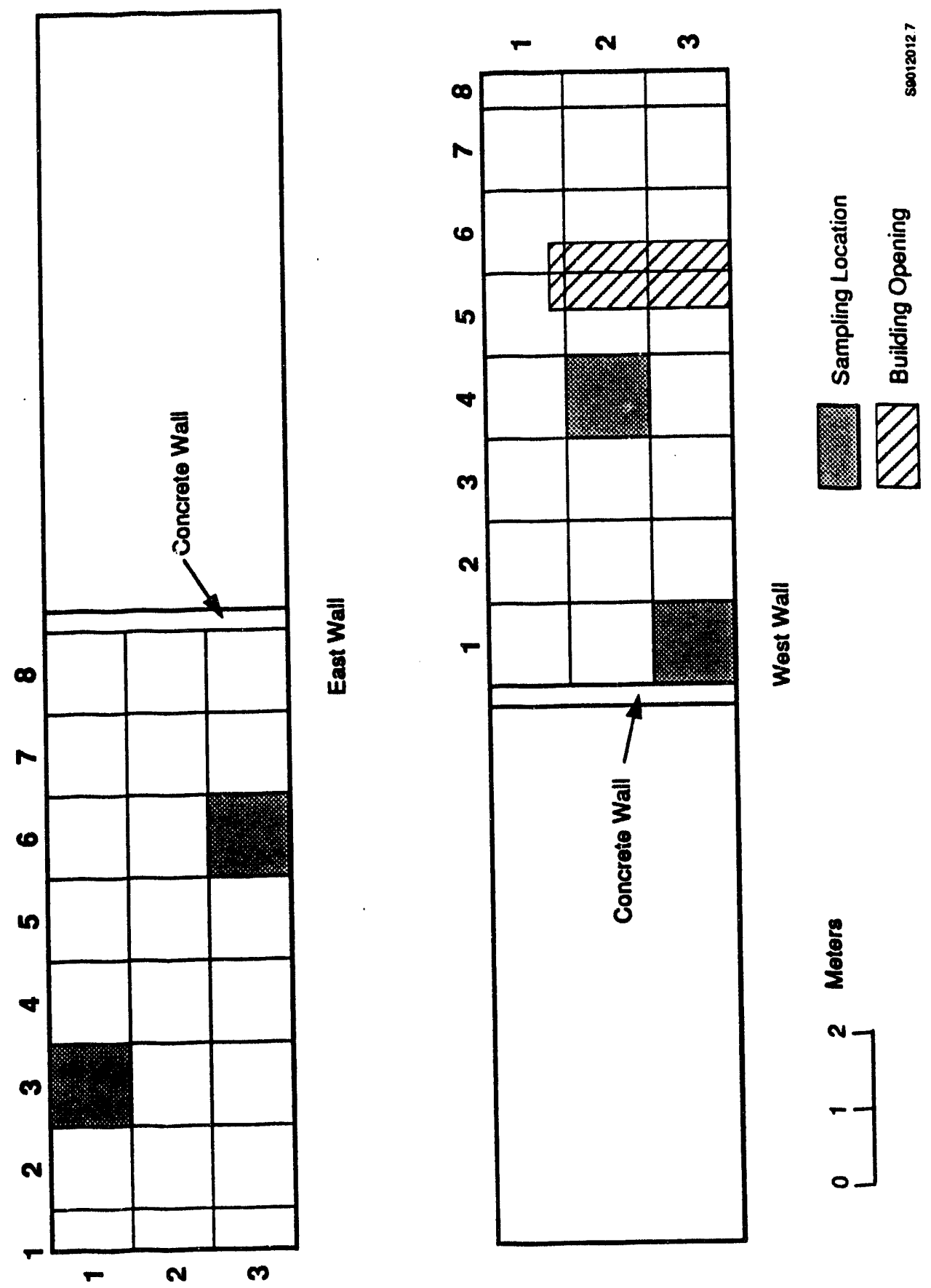

Figure 7-6. 303-K Storage Facility, East and West Wall Sampling Location. 
DOE/RL-90-04, Rev. 2

$12 / 15 / 93$

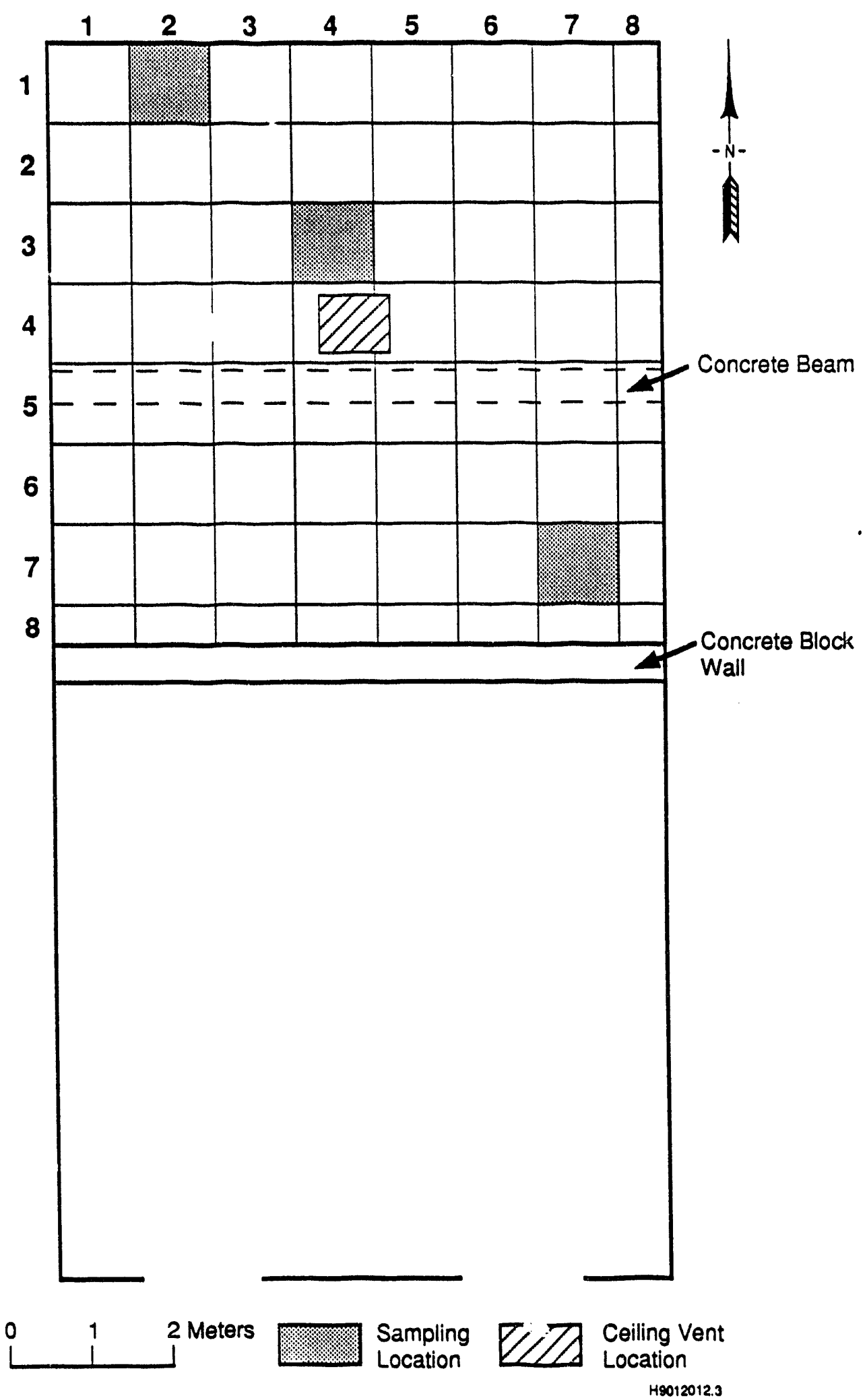

Figure 7-7. 303-K Storage Facility, Ceiling Sampling Locations. 


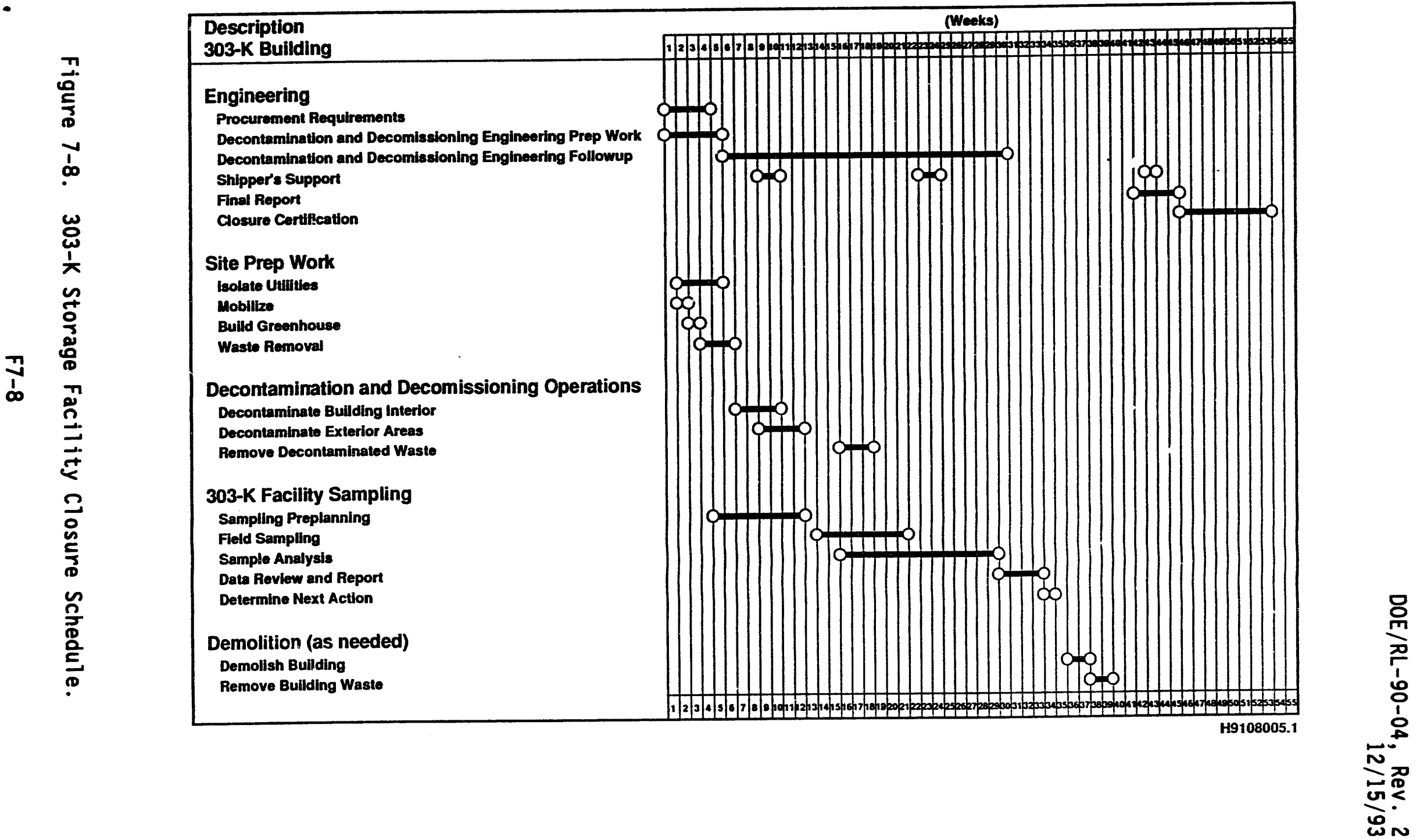


DOE/RL-90-04, Rev. 2

$12 / 15 / 93$

\section{CLOSURE CERTIFICATION}

FOR

Hanford Facility
U.S. Department of Energy, Richland Field Office

We, the undersigned, hereby certify that all

closure activities were performed in accordance with the specifications in the approved closure plan.

Owner/Operator Signature DOE-RL Representative (Typed Name)

P.E.\# State

Signature Independent Registered Professional Engineer State - Date (Typed Name, Professional Engineer Iicense number, state of issuance, and date of signature)

Figure 7-9. Closure Certification for the 303-K Storage Facility. 
Table 7-1. Potential Compliance Constituents, Analytical Methods, and Action Levels for the 303-K Storage Facility.

Constituent/perameter

\begin{tabular}{l|l}
\hline Arsenic & \\
\hline
\end{tabular}

\section{Barium}

Beryllium

Cacmium

chloride

chromiun

Lead

1 Mercury

13 Nitrate

14 Nitrite

15 silver

16 uranium

17 Perchloroethylene

18 Trichloroethylene

19 1,1,1-Trichloroethane

20 1-1-Dichloroethylene

21 cis-1,2-0ichloroethylene

22 trans-1-2-0ichloroethylene

23 Toluone

24 Tetrachloroethylene

25 Ethyl acetate

26 Methyl ethyl ketone

27 Pentrechlorophenol

28 Vinyl chloride

EPA, 1989, The Determination of Inorganic Anions in Hater by Ion Chromatography - Method 300.00,

U.S. Envi ronmental Protection Agency, Washington, D.C.

EPA, 1984, Eastern Environmental Radiation Facility Radiochemistry Procedures Manual, EPA 520/5-84/006, U.S. Environmental Protection Agency/Eaetern Environmental Radiation Facil ity, Montgomery, Alabsem.

Extrection concrete inorganic anolysis methodology, section 7.2.9.1: first extraction by acid digestion solution, second extraction by toxic characteristic leach procedure solution.

foncrete organic analysis methodology, saction 7.2.9.2: extraction by sonic desorption method.

To be determined; no SW-846 method exists; will use a laboratory specific method.

$>S L B=$ greater then site-wide soil beckground threshold.

$L O O=$ limit of quantitation.

$M A=$ not applicable (analyzed for information only)

* SCINTREX is a trademark of SCINTREX, Inc. 
Table 7-2. Sampling Summary of the 303-K Storage Facility.

\begin{tabular}{l} 
Location \\
\hline $\begin{array}{l}\text { North wall } \\
\text { Concrete core samples } \\
\text { Random }\end{array}$
\end{tabular}

South wall

Concrete core samples

Random

2

7.

East wall

Concrete core samples

Random

West wall

Ceiling Concrete core samples Random

Floor

Concrete core samples

Random

Authoritative

3

Soil

Authoritative

Outside storage pads

Concrete core samples

Random

Asphalt core samples

Random

Soll

Random (gravel storage area)

Authoritative (beneath potential

pathways)

5

13

5

$\sim 4$

33 
DOE/RL-90-04, Rev. 2

$12 / 15 / 93$

1

Table 7-3. Field Quality Control Samples.

2 Number of

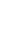

3

4

5

6

7

8

9

\begin{tabular}{lccccc}
\hline Type of sample & $\begin{array}{c}\text { Number of } \\
\text { sampling } \\
\text { locations }\end{array}$ & $\begin{array}{c}\text { Equipment } \\
\text { blank }\end{array}$ & $\begin{array}{c}\text { Field } \\
\text { blank }\end{array}$ & $\begin{array}{c}\text { Trip } \\
\text { blank }\end{array}$ & $\begin{array}{c}\text { Duplicate } \\
\text { blank }\end{array}$ \\
\hline Concrete & 21 & 1 & 1 & 1 & 1 \\
Soil & 10 & 1 & 1 & 1 & 1 \\
Asphalt & 13 & 1 & 1 & 1 & 1 \\
\hline $\begin{array}{l}\text { Assumptions: } \\
\text { quality control samples. If samples of each type are not completed } \\
\text { in one day, quality control samples will be collected each day. }\end{array}$
\end{tabular}


Table 7-4. General Training Matrix.

\begin{tabular}{|c|c|c|c|c|c|c|c|}
\hline \multirow{2}{*}{2} & \multirow{2}{*}{ Course title } & \multirow[b]{2}{*}{ Type } & \multicolumn{5}{|c|}{ Target/Audience } \\
\hline & & & MS & MO & HPT & CR & $s$ \\
\hline 3 & Generator Hazards Safety Training & I & $x$ & $x$ & $x$ & $x$ & $x$ \\
\hline 4 & Hazardous Waste Worker Safety Training & I & $x$ & $x$ & $\mathrm{x}$ & $x$ & $\mathrm{x}$ \\
\hline $\begin{array}{l}5 \\
6\end{array}$ & $\begin{array}{l}\text { Hazardous Waste Worker Safety Training, } \\
\text { Refresher }\end{array}$ & c & $x$ & $x$ & $x$ & $x$ & $x$ \\
\hline $\begin{array}{l}7 \\
8\end{array}$ & $\begin{array}{l}\text { Hazardous Materials/Waste Job-Specific } \\
\text { Training }\end{array}$ & I & $x$ & $x$ & $x$ & $\mathrm{x}$ & $x$ \\
\hline 9 & Scott "SKA-PAK MSA PAPR & c & $x$ & $x$ & $x$ & $x$ & $x$ \\
\hline 10 & $\begin{array}{l}\text { Self-Contained Breathing Apparatus } \\
\text { (SCBA) Training (optional) }\end{array}$ & C & $x$ & $x$ & $\mathrm{x}$ & $x$ & $x$ \\
\hline 12 & Radiation Safety Training & c & $x$ & $x$ & $x$ & $x$ & $x$ \\
\hline 13 & On-the-Job Training & C & $x$ & $x$ & $x$ & $x$ & $x$ \\
\hline 14 & Cardiopulmonary Resuscitation & C & $x$ & $x$ & $x$ & $x$ & $x$ \\
\hline 15 & Noise Control (optional) & c & $x$ & $x$ & $x$ & $x$ & $\mathrm{x}$ \\
\hline 16 & $\begin{array}{l}\text { Hazardous Waste Site Supervisor/ } \\
\text { Manager Safety Management Training }\end{array}$ & I & $x$ & -- & -- & -- & -- \\
\hline
\end{tabular}

$C=$ continuing course.

$C R=$ crafts.

HPT = health physics technicians.

$I=$ introductory course.

MO = metal operator

MS = manager and supervisors.

$S=$ samplers.

$X=$ required course.

"SKA-PAK is a trademark of Figgie, International.

28 
DOE/RL-90-04, Rev. 2

$12 / 15 / 93$

\section{CONTENTS}

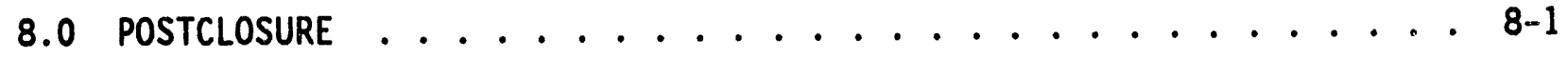

8.1 NOTICE-IN-DEED . . . . . . . . . . . . . 8-1

8.2 POSTCLOSURE CARE ..................... 8-2 
DOE/RL-90-04, Rev. 2

$12 / 15 / 93$

This page intentionally left blank. 
DOE/RL-90-04, Rev. 2

$12 / 15 / 93$

\subsection{POSTCLOSURE}

This chapter discusses what will occur if the clean-closure requirements cannot be met.

\subsection{NOTICE-IN-DEED}

This closure plan is proposing clean closure of the 303-K Storage Facility. However, if clean closure cannot be obtained, the following action will be taken in accordance with WAC 173-303-610 (1)(b). Within 60 days of the certification of closure, the DOE-RL will sign, notarize, and file for recording the notice indicated below. The notice will be sent to the Auditor of Benton County, P. 0 . Box 470, Prosser, Washington, with instructions to record this notice in the deed book.

TO WHOM IT MAY CONCERN

The United States Department of Energy, Richland Operations Office, an operations office of the United States Department of Energy, which is a department of the United States government, the undersigned, whose local address is the Federal Building, 825 Jadwin Avenue, Richland, Washington, hereby gives the following notice as required by 40 CFR 265.120 and WAC 173-303-610(10) (whichever is applicable).

(a) The United States of America is, and since April 1943, has been in possession in fee simple of the following described lands: (legal description of 303-K Storage Facility site).

(b) The United States Department of Energy, Richland Operations Office, by operation of the 303-K Storage Facility, has disposed of hazardous and/or dangerous waste under the terms of regulations promulgated by the United States Environmental Protection Agency and Washington State Department of Ecology (whichever is applicable) at the above described 1 and.

(c) The future use of the above described land is restricted under terms of 40 CFR 264.117(c) and WAC 173-303-610(7)(d) (whichever is applicable).

(d) Any and all future purchasers of this land should inform themselves of the requirements of the regulations and ascertain the amount and nature of waste disposed of on the above described property.

(e) The United States Department of Energy, Richland Operations Office has filed a survey plat with the Benton County Planning Department and with the United States Environmental Protection Agency, 
Region 10, and the Washington State Department of Ecology (whichever are applicable) showing the location and dimensions of the 303-K Storage Facility site and a record of the type, location, and quantity of waste treated.

\subsection{POSTCLOSURE CARE}

Postclosure care generally is required when a TSD unit cannot attain a clean closure. At the 303-K Storage Facility, underlying soils and groundwater might have been contaminated by waste generated during past-practice operations in the 300 Area. Under the Tri-Party Agreement (Ecology et al. 1992), a procedure to coordinate the TSD unit closure or permitting activity with the past-practice investigation and remediation activity is necessary to prevent overlap and duplication of work, thereby economically and efficiently addressing the contamination.

With the exception of an imminent health threat, all soil remediation will take place under the CERCLA remedial action process. If the soil within the 303-K Storage Facility boundary is found to be contaminated (chemical concentrations above local background threshold and health-based standards) from operations conducted (chemicals used or waste stored) in the 303-K Storage Facility, the 303-K Storage Facility will not be considered closed until the remediation under CERCLA is complete. During the time between closure of the building, floor, and pads and any soil remediation under CERCLA, steps will be taken to isolate any contamination.

Any data obtained from sampling and analyses during closure activities will be part of the record and included in the closure plan. These data will be taken into account and used during the CERCLA evaluation of the 300-FF-3 operable unit, as well as data collected specifically for the Cl:RCLA evaluation.

Temporary covers will be installed, if necessary, to prevent migration of any contamination. The temporary covers would be less permeable than the surrounding soil and could be composed of constituents such as asphalt, clay, concrete, synthetic liner, or a fixative spray. The existing floor and pads might be used as covers if these were found to be uncontaminated or were decontaminated. The exact nature of any covers would be determined at the time the need was identified, and this information would be added to the closure plan. In addition, access to the areas of contamination would be controlled, if necessary, to protect personnel or prevent the migration of cortamination.

During the period between closure of the building and soil remediation under CERCLA, the closure area would be inspected at a minimum of once a week. This inspection would be combined with inspections presently conducted. The inspections would determine the need for maintenance of any temporary covers or other physical barriers. Any required maintenance would be performed by trained personnel. 
DOE/RL-90-04, Rev. 2

$12 / 15 / 93$

\section{CONTENTS}

9.0 REFERENCES . . . . . . . . . . . . . . . . . . 9 . .

9.1 DOCUMENTS . . . . . . . . . . . . . . . . 9-1

9.2 CODE OF FEDERAL REGULATIONS . . . . . . . . . . . . 9-2

9.3 FEDERAL AND STATE ACTS . . . . . . . . . . . . . 9-2 
DOE/RL-90-04, Rev. 2

$12 / 15 / 93$

This page intentionally left blank. 
DOE/RL-90-04, Rev. 2

$12 / 15 / 93$

\subsection{REFERENCES}

\subsection{DOCUMENTS}

Conway, R. A., 1982, Environmental Risk Analysis for Chemicals, Van Nostrand Reinhold, New York, New York.

DOE-RL, 1989, Draft Remedial Investigation/Feasibility Study Work Plan for the 300-FF-5 Operable Unit, Hanford Site, Richland, Washington, DOE/RL 89-14, U.S. Department of Energy-Richland Operations Office, Richland, Washington.

DOE-RL, 1992a, Hanford Site Soil Background, DOE/RL-92-24, U.S. Department of Energy, Richland Field Office, Richland, Washington.

DOE-RL, 1992b, Hanford Site Baseline Risk Assessment Methodology, DOE/RL 91-45, U.S. Department of Energy-Richland Operations Office, Richland, Washington.

Ecology, 1986, Use of Toxicity Test Procedures to Determine Additional Testing Requirements for Certain Waste Streams Containing Copper, Nickel, and Zinc, Memorandum TIM No. 86-1, September 15, 1986, Washington State Department of Ecology, Olympia, Washington.

Ecology, EPA, and DOE, 1992, Hanford Federal Facility Agreement and Consent Order, Vol. 1 and 2, Washington State Department of Ecology,

U.S. Environmental Protection Agency, and U.S. Department of Energy, Olympia, Washington.

EPA, 1984a, Eastern Environmental Radiation Facility Radiochemistry Procedures Manual, EPA-520/5-84-006, U.S. Environmental Protection Agency/Eastern Environmental Radiation Facility, Montgomery, Alabama.

EPA, 1984b, Soil Sampling Quality Assurance User's Guide, EPA-600/14-84-0483, U.S. Environmental Protection Agency, Washington, D.C.

EPA, 1985, Asbestos Waste Management Guidance, EPA/530-SW-85-007, U.S. Environmental Protection Agency, Washington, D.C.

EPA, 1986, Test Methods for Evaluating Solid Waste - Physical/Chemical Methods, SW-846, 3rd ed., U.S. Environmental Protection Agency, Washington, D.C.

EPA, 1989a, Risk Assessment Guidance for Superfund: Human Health Evaluation Manual, Part A, Chapter 6, Exposure Assessment, U.S. Environmental Protection Agency, Washington, D.C.

EPA, 1989b, Statistical Analysis of Ground Water Monitoring Data at RCRA Facilities, Interim Findl Guidance, Environmental Protection Agency, Washington, D.C. 
EPA, 1993, Integrated Risk Information System (IRIS), U.S. Environmental Protection Agency, Washington, D.C., updated monthly.

Freeze, R. A., and J. A. Cherry, 1979, Groundwater, Prentice-Hall, Inc., Englewood Cliffs, New Jersey.

Pendias, A. K., and H. Pendias, 1984, Trace Elements in Soil and Plants, CRC Press, Inc., Boca Raton, Florida.

Routson, R. C., W. H. Price, D. J. Brown, and K. R. Fecht, 1979, High Level Waste Leakage from the 241-ST-106 Tank at Hanford, RHIO-ST-14, Rockwell Hanford Operations, Richland, Washington.

WHC, 1988, Environmental Investigations and Site Characterization Manual, WHC-CM-7-7, Westinghouse Hanford Company, Richland, Washington.

WHC, 1991, Hanford Site Solid Waste Acceptance Criteria, WHC-EP-0063-3, Westinghouse Hanford Company, Richland, Washington, updated periodically.

\subsection{CODE OF FEDERAL REGULATIONS}

29 CFR 1910, "Occupational Safety and Health Standards," Title 29, Code of Federal Regulations, Part 1910, as amended, Occupational Safety and Health Administration, Washington, D.C.

40 CFR 261, "Identification and Listing of Hazardous Wastes," Title 40, Code of Federal Regulations, Part 261, as amended, U.S. Environmental Protection Agency, Washington, D.C.

40 CFR 264, "Standards for Owners and Operators of Hazardous Waste Treatment, Storage and Disposal Facilities," Title 40, Code of Federal Regulations, Part 264, as amended, U.S. Environmental Protection Agency, Washington, D.C.

40 CFR 265, "Interim Status Standards for Owners and Operators of Hazardous Waste Treatment, Storage and Disposal Facilities, "Title 40, Code of Federal Regulations, Part 265, as amended, U.S. Environmental Protection Agency, Washington, D.C.

\subsection{FEDERAL AND STATE ACTS}

Comprehensive Environmental Response, Compensation, and Liability Aci of 1980, as amended, 42 USC 9601 et seq.

Resource Conservation and Recovery Act of 1976, as amended, 42 USC 6901, et seq. 
DOE/RL-90-04, Rev. 2

$12 / 15 / 93$

\section{APPENDICES}

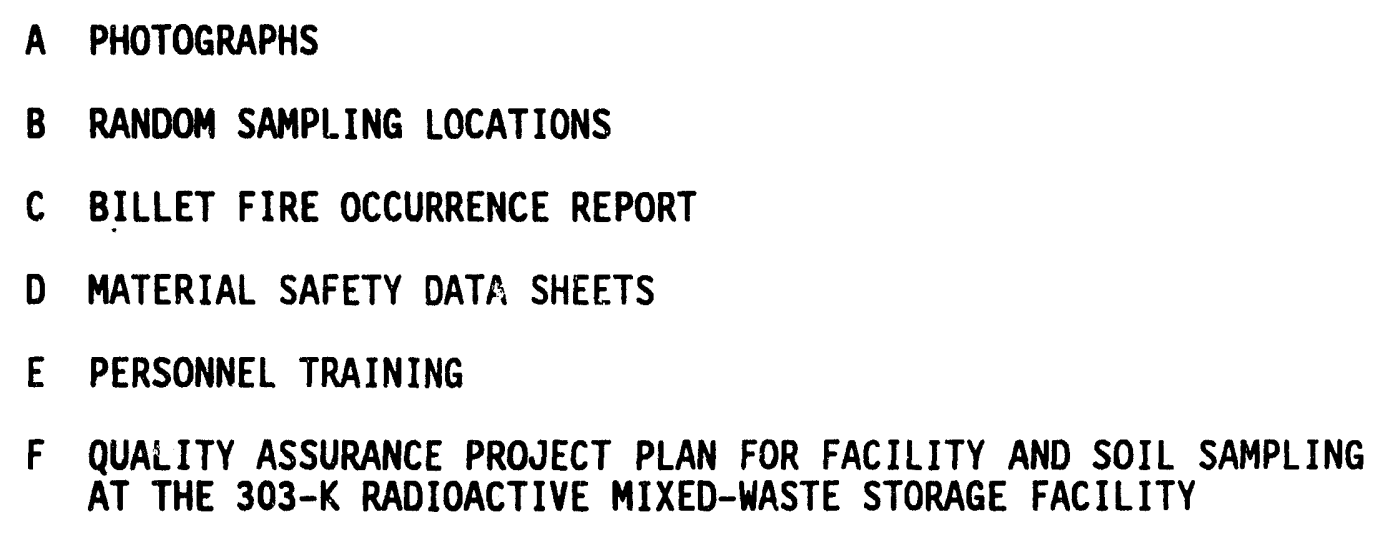

B RANDOM SAMPLING LOCATIONS

F QUALITY ASSURANCE PROJECT PLAN FOR FACILITY AND SOIL SAMPLING AT THE 303-K RADIOACTIVE MIXED-WASTE STORAGE FACILITY 
DOE/RL-90-04, Rev. 2

$12 / 15 / 93$

This page intentionally left blank. 
DOE/RL-90-04, Rev. 2

$12 / 15 / 93$

\section{APPENDIX A}

\section{PHOTOGRAPHS}

APP $A-i$ 
DOE/RL-90-04, Rev. 2

$12 / 15 / 93$

This page intentionally left blank. 


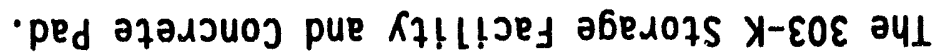

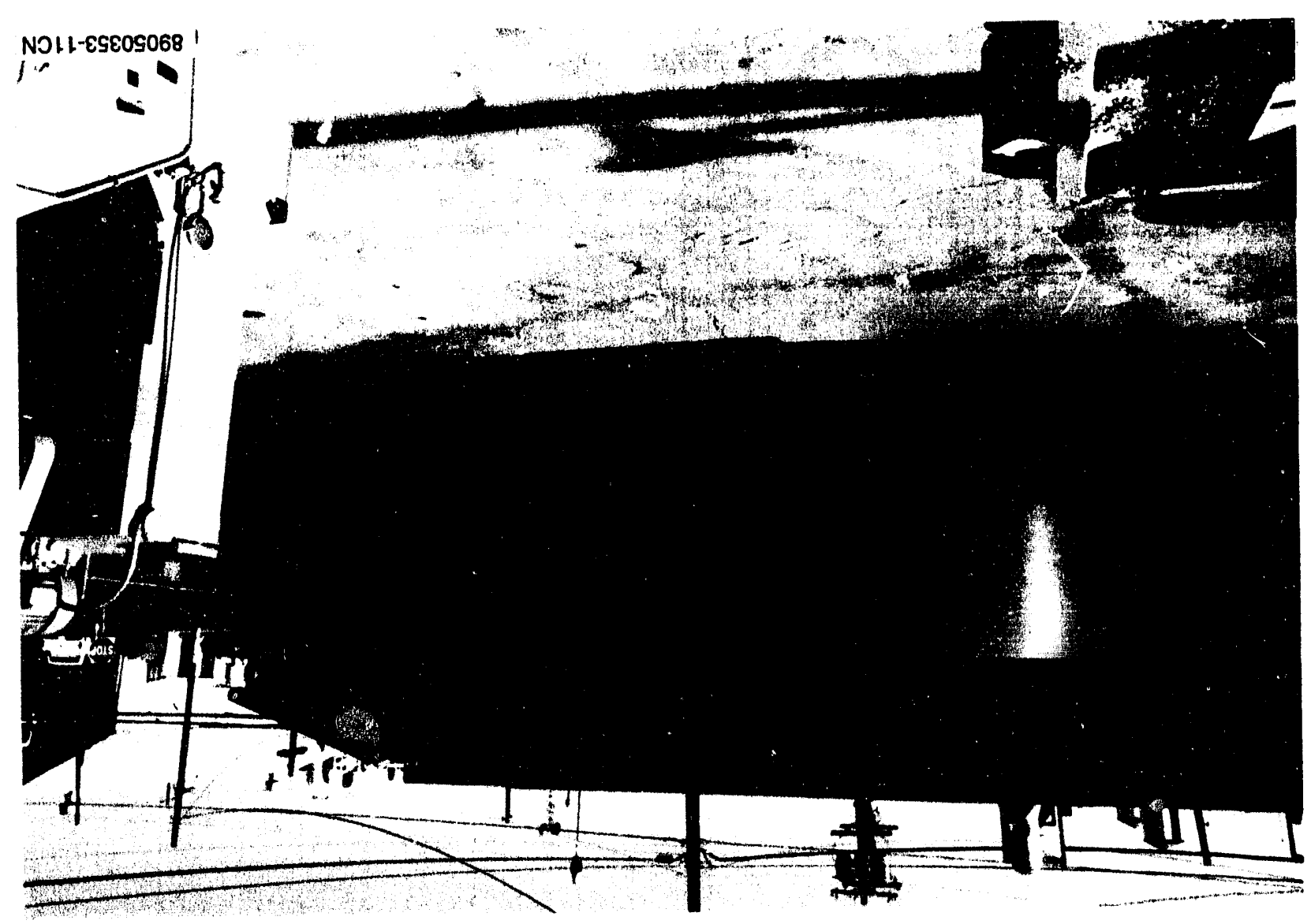




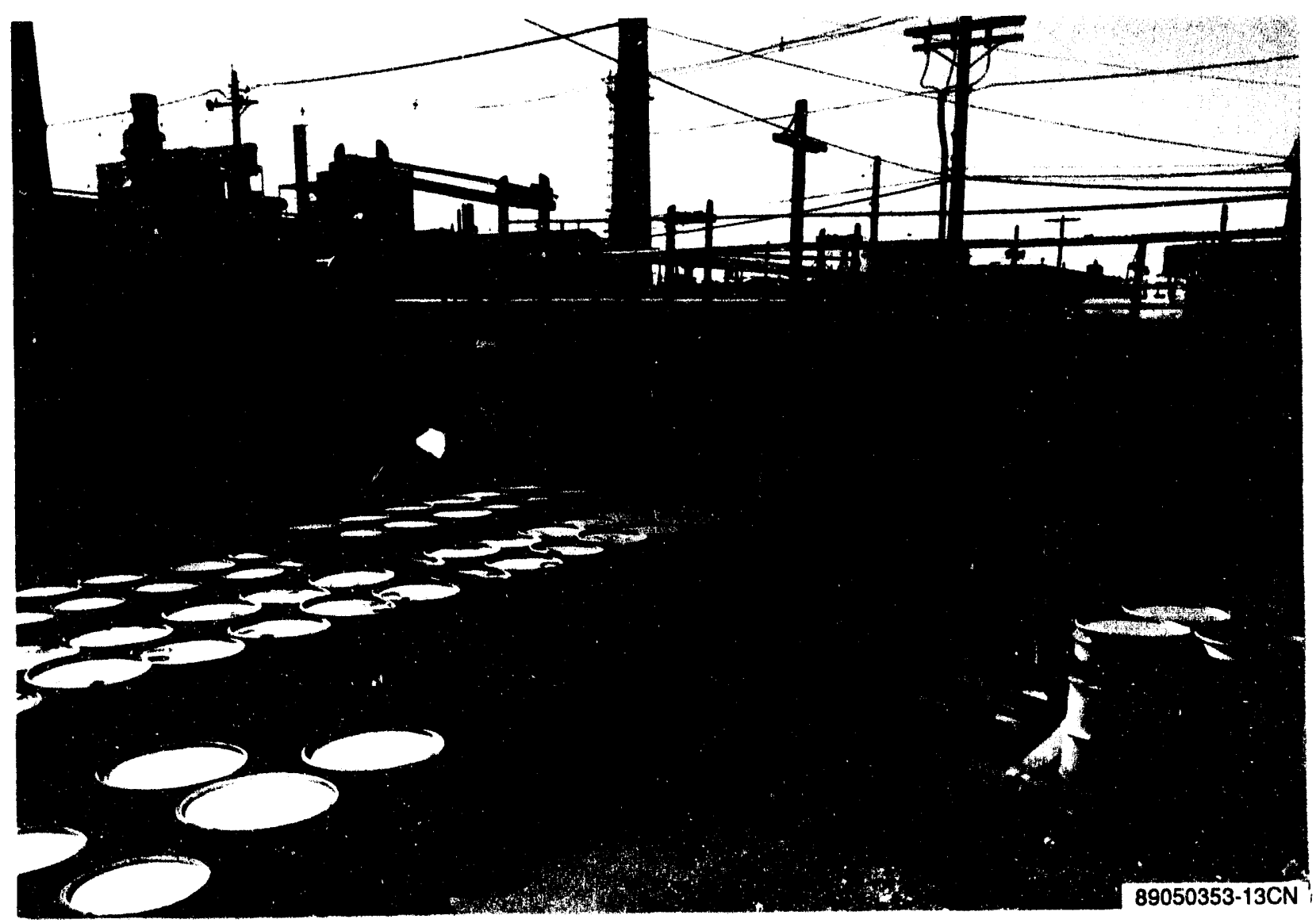

The 303-K Storage Facility Asphalt Pad. 
DOE/RL-90-04, Rev. 2

$12 / 15 / 93$

\section{APPENDIX B}

RANDON SAMPLING LOCATIONS 


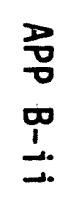

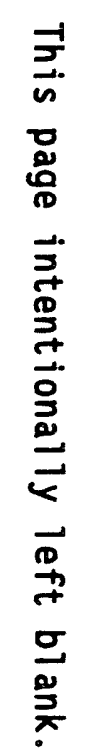

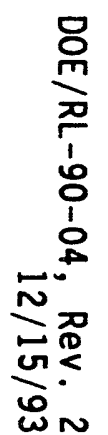


Table B-1. The 303-K Storage Facility Random Sampling Locations - 5 Percent of the Available Sampling Locations are Selected.

\begin{tabular}{cccc}
\hline $\begin{array}{c}\text { East wall } \\
\text { Figure }\end{array}$ (refer to & \multicolumn{2}{c}{$\begin{array}{c}\text { West wall } \\
\text { Figure }\end{array}$} & $\begin{array}{c}(\text { rffifer to } \\
7-6)\end{array}$ \\
\hline 6 & 3 & 4 & 2 \\
3 & 1 & 1 & 3 \\
5 & 2 & 6 & 2 \\
1 & 2 & 7 & 2 \\
5 & 2 & 8 & 3 \\
6 & 3 & 6 & 3 \\
4 & 1 & 5 & 1 \\
\hline
\end{tabular}

13

South wall (inside) (refer North wall (refer to to Figure 7-5) Figure 7-5)

\begin{tabular}{llll}
\hline 5 & 1 & 6 & 2 \\
6 & 3 & 8 & 3 \\
2 & 1 & 2 & 1 \\
7 & 3 & 7 & 2 \\
4 & 1 & 6 & 3 \\
7 & 3 & 3 & 3 \\
5 & 1 & 7 & 1 \\
\hline
\end{tabular}

22 
1

2

3

4
5

6

7

8

9

10

11

12

13

14

15

16

17

18

19
Table B-2. 303-K Storage Facility Random Sampling Locations - 5 Percent of the Available Sampling Locations are Selected.

\begin{tabular}{cccc}
\hline $\begin{array}{c}303-K \text { Floor } \\
\text { Figure }\end{array}$ (ref-2) \\
$X$ Coordinate & $Y$ Coordinate & X Coordinate & $\begin{array}{c}\text { Ceiling (refer to } \\
\text { Figure } 7-7)\end{array}$ \\
\hline 6 & 2 & 2 & 1 \\
7 & 5 & 4 & 3 \\
2 & 6 & 7 & 7 \\
5 & 7 & 6 & 6 \\
3 & 1 & 2 & 8 \\
1 & 6 & 4 & 2 \\
8 & 4 & 1 & 7 \\
5 & 1 & 8 & 8 \\
6 & 2 & 3 & 6 \\
4 & 8 & 8 & 3 \\
5 & 2 & 6 & 2 \\
6 & 5 & 4 & 7 \\
\hline
\end{tabular}


Table B-3. 303-K Storage Facility Random Sampling Locations Outside Storage Pads - 5 Percent of the Available Sampling Locations are Selected. (sheet 1 of 2)

\begin{tabular}{|c|c|c|c|}
\hline \multicolumn{2}{|c|}{$\begin{array}{l}\text { Gravel area } \\
\text { (refer to Figure } 7-3 \text { ) }\end{array}$} & \multicolumn{2}{|c|}{$\begin{array}{l}\text { Small concrete pad } \\
\text { (refer to Figure } 7-3 \text { ) }\end{array}$} \\
\hline$X$ Coordinate & Y Coordinate & $x$ Coordinate & Y Coordinate \\
\hline 3 & 14 & $?$ & 2 \\
\hline 2 & 3 & 3 & 2 \\
\hline 2 & 15 & 3 & 1 \\
\hline 1 & 8 & 1 & 4 \\
\hline 4 & 1 & 2 & 2 \\
\hline 3 & 6 & 2 & 1 \\
\hline 2 & 12 & 2 & 4 \\
\hline 1 & 4 & 1 & 1 \\
\hline 6 & 3 & 1 & 4 \\
\hline 3 & 10 & 1 & 2 \\
\hline 3 & 2 & & \\
\hline \multirow[t]{3}{*}{4} & 14 & \multicolumn{2}{|c|}{$\begin{array}{l}\text { Small Asphalt Pad } \\
\text { (refer to Figure 7-3) }\end{array}$} \\
\hline & & $x$ Coordinate & Y Coordinate \\
\hline & & 2 & 1 \\
\hline
\end{tabular}




\begin{tabular}{|c|c|c|c|c|}
\hline $\begin{array}{l}1 \\
2 \\
3 \\
4\end{array}$ & $\begin{array}{c}\text { Table B-3 } \\
\text { Locations } \\
\text { Avail }\end{array}$ & $\begin{array}{r}\text { 303-K Storag } \\
\text { Dutside Storac } \\
\text { le Sampling L } \\
\text { (sheet }\end{array}$ & $\begin{array}{l}\text { Facility Rand } \\
\text { Pads - } 5 \text { Per } \\
\text { :ations are Se } \\
\text { of } 2 \text { ) }\end{array}$ & $\begin{array}{l}\text { Sampling } \\
\text { nt of the } \\
\text { cted. }\end{array}$ \\
\hline $\begin{array}{l}5 \\
6\end{array}$ & $\begin{array}{l}\text { Large col } \\
\text { (refer to }\end{array}$ & $\begin{array}{l}\text { rete pad } \\
\text { igure } 7-3 \text { ) }\end{array}$ & $\begin{array}{l}\text { Large a: } \\
\text { (refer to }\end{array}$ & $\begin{array}{l}\text { halt pad } \\
\text { igure } 7-3 \text { ) }\end{array}$ \\
\hline 7 & $X$ Coordinate & Y Coordinate & $x$ Coordinate & $Y$ Coordinate \\
\hline 8 & 4 & 10 & 18 & 6 \\
\hline 9 & 4 & 9 & 16 & 8 \\
\hline 10 & 4 & 1 & 14 & 7 \\
\hline 11 & 2 & 8 & 9 & 4 \\
\hline 12 & 3 & 6 & 20 & 9 \\
\hline 13 & 1 & 3 & 1 & 1 \\
\hline 14 & 5 & 2 & 8 & 8 \\
\hline 15 & 7 & 10 & 11 & 10 \\
\hline 16 & 3 & 2 & 7 & 5 \\
\hline 17 & 3 & 6 & 7 & 3 \\
\hline 18 & 5 & 5 & 6 & 1 \\
\hline 19 & 6 & 4 & 12 & 4 \\
\hline 20 & & & 9 & 1 \\
\hline 21 & & & 17 & 3 \\
\hline 22 & & & 16 & 1 \\
\hline 23 & & & 15 & 10 \\
\hline
\end{tabular}

24 
DOE/RL-90-04, Rev. 2

$12 / 15 / 93$

\section{APPENDIX C}

BILLET FIRE OCCURRENCE REPORT 
DOE/RL-90-04, Rev. 2

$12 / 15 / 93$

This page intentionally left blank. 
DOE/RL-90-04

OCCURRENCE REPORT

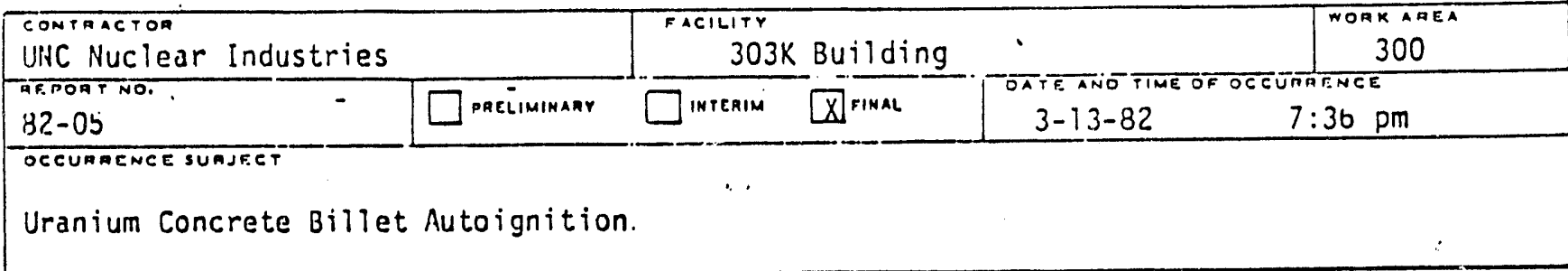

1. OESCRIDTION OF OCCURAENCE ANO DESIGNATION OF APPAAEN T CAUSE

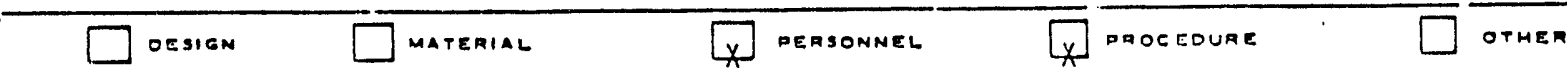

At 7:36 pm on Saturday, March 13, Hanford Patrol observed a flashing beacon on their 303C rcmote camera inonitor. After confirming the location of the alarm beacon on the roof of $3707 G$ Building, Hanford Patrol notified HEDL personnel. The alarm beacon of the $303 \mathrm{~K}$ Building roof indicates that the Hydrogen monitor in the building exhaust duct has exceeded the specified set point. The UINC coverage operator was then notified. The appropriate UivC supervisory personnel were contacted. Upon arrival at $3: 30$ pri, the INNC Materials Services supervisor observed that one pallet of concrete billet cans was on fire. All billets in $303 \mathrm{~K}$ at the time were found to be on wooden pallets. A fire alarm was imnediately called in by the coverage operator.

The Hanford Fire Department arrived on the scene at approximately 8:46 pm, and entered the radiation zone to fight the fire. UNC Radiation Monitoring personnel were contacted at approximately 10:00 pm, and arrived on the scene to relieve the $\mathrm{HEDL}$ monitor at $10: 15 \mathrm{pm}$.

Air samples and radiation surveys taken in the general area indicated no contamination release. However, two of the fire fighters were contaminated on their face, hands, and clothes. In addition, nasal smears indicatec potential internal contamination. The UNC monitor contacted the Battelle Exposure Evaluator's office to request a whole body count. Preliminary results of whole body counts, lung counts, and bioassay analyses indicate that the exposure of the two firemen was less than $5 \%$ of the annual dose 1 imit.

The cause of the oillet autoignition could not be defined with certainty. The investigation into this incident did reveal areas of the concretion operation which are believed to have contributed to the fire, and which need to be corrected. These corrections include revisions to process specifications and operating procedures, retraining of Operations personnel, and development of a system to verify all processing parameters for concretion campaigns. However, in addition to these, it has been recognized that there is always some risk of a billet fire in the $303 \mathrm{~K}$ Building during the curing cycle, since this process subjects the billets to telmperatures higher than they could ever see during shipment back to the feedsite for reprocessing. As such, it has been described as a "burning test".

(Continued on attachment.)

2. OPEAATING CONOITIONS OF THE FACILITY AT TIME OF OCCUARENCE IIF APMLICABLEI

The 303K Building was operating under high temperature curing cycle conditions for uranium concrete billets. This involves establishing and maintaining an internal building temperature of approximately $61^{\circ} \mathrm{C}$. There were approximately 12 pallets, each with 12 concrete billet cans, in the facility at the time of the incident. The concreted billets contained $0.95 \%$ enriched $\mathrm{U}-235$. 
After contacting supervisory personnel, the coverage operator turned off all building heat and verified operation of the exhaust system.

It was determined that one pallet of billets was involved in the fire. Two other pallets of billet cans were moved to the fenced outer radiation zone area to provide access to the burning pallet. One of the Lurning billet cans was pulled outside. It was later moved back inside the building. The burned, debris was spread out over the floor area within 303K, the cans removed, and the fire extinguished with graphite microspheriods and Met-L-X.

A UNC management team convened on March 14, 1982, and devcloped a "First Stage Recovery Plan". These actions were accomplished primarily to remove all other combustible materials RECOMMENOATIONS

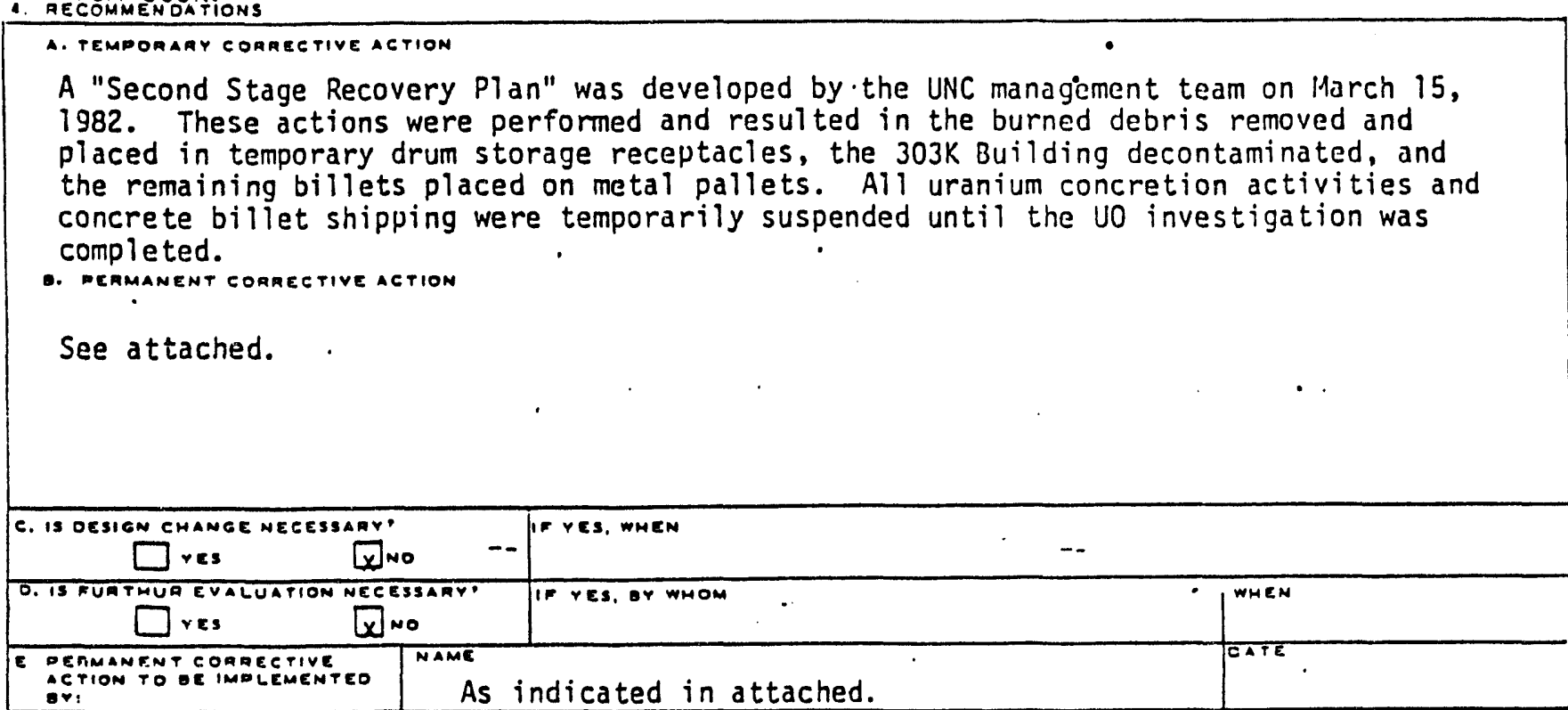

3. SIMILAR OCCURAENCE: OY REPOAT NUMEER ANO OCCURRENCE SUBJECT

UE 77-2 was written in response to a uranium concrete billet fire in the 304 Building August 8, 1977.

U0 79-27 was written in response to a uranium concrete billet fire in the 3712 Building August 2, 1979.

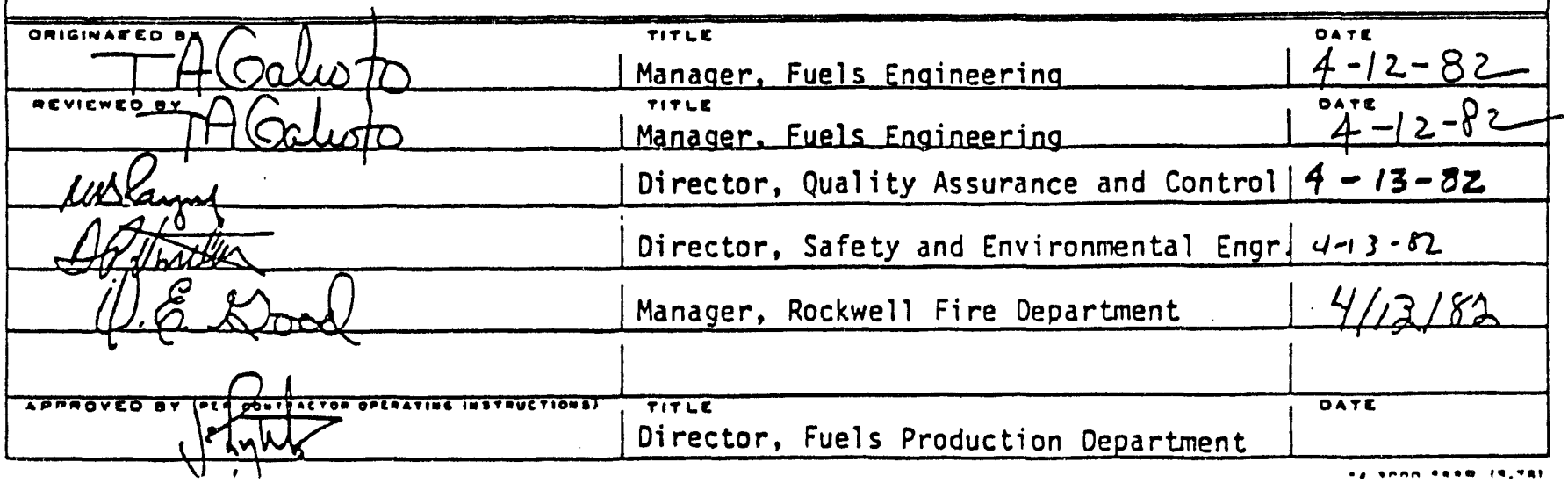




\section{UO INVESTIGATION COMMITTEE REPORT}

Commi ttee ilembers:

T. A. Galioto, Manager Fuels Engineering: Chairman

E. A. Weakley, Principal Engineer: Causal Factors Analyst and Technical Investigator

L. C. Horobiowski, Engineer: Fire/Safety Investigator

L. E. Thurnan, Supervisor R\&WQC: Radiation Control Investigator

D. L. DelNeal, Fuels Operations Supervisor; Operations Investigator

G. E. Bentley, Quality Engineer; Qual ity Control Investigator

Committee Activities

The UO Investigation Committee was formed on March 16, 1982, at which time the investigation activities were identified. These included interviews with involved parties, examination of available Operations records, and determination of cause/ corrective actions required.

Summary of Miscellaneous Incident Evaluations

Air samples taken by the PNL Environmental Evaluations Section on ilarch 14, indicated no contamination above background. These were taken from sample stations located within the 300 Area and across the Columbia River to the northeast. These samples are currently undergoing final evaluation for uranium count.

A radiation survey of the exhaust system on the $303 \mathrm{~K}$ roof indicated a maximum level of $600 \mathrm{cpm}$ upstream of the HEPA filter, and no detectable levels downstream of the filter.

Material accountabiliziy for the uranium involved in the fire cannot be determined until the fire debris is re-concreted. At that time, a sample will be taken of the debris to determine percent of uranium, and coupled with total debris weight will provide a measure for accountability. Also, added to this debris will be the material recovered from the drain filter in! $303 \mathrm{~K}$ after the room was washed down. Actual loss of material as a result of the fire is expected to be insignificant. These losses will occur as a result of material not caught in the drain filter in $303 \mathrm{~K}$, and material on wipe rags and cleaning tools during building decontamination. A total of 763 pounds of uraninium were contained in the 12 concrete billets that were burned.

Two Rockwell firemen showed evidence of external and internal contamination upon exiting the radiation zone subsequent to firefighting activities. From accounts given by other personnel at the scene, and from interviews with the firemen involved, this contamination most likely occurred due to inadequate dress/undress procedures. Breathing air apparatus was removed after exiting the $303 \mathrm{~K}$ Building, and then the same masks were repositioned for a second building entrance by the firemen. Aiso, lack of sufficient care in undressing prior to exiting the zone could have contributed to the contamination. This was complicated by the undressing assistance that the firemen received from other personnel at the scene. A burning uranium concrete billet was pulled out of the $303 \mathrm{~K}$ Building by firefighters (still within radiation zone perimeter) which could have potentialiy contributed to contamination spread.

Final results of the bioassay analyses for the two contaminated firemen will not be available for approximately one month. This is due in part to the need to evaluate the solubility of the contaminants (as determined from a smear sample taken from the wall of 303K on March 17, 1982). 
DOE/RL-90-04

U0 $82-05$

1. Description of Occurrence and Designation of Apparent Cause (continued) With implementation of the corrective actions identified herein, the severity and frequency of future fires can be reduced, but elimination of fires cannot be guaranteed. 
UO Investigation Conmittee Report - U0 82-05

Page 2

It was also learned that the Rockwell Fire Department uses pre-fire plans for buildings for training purposes only, and does not pull these plans when responding to an actual fire call. As a result, initial response to the 303K * fire was somewhat hampered, with firefighters utilizing UNC management at the scene for information on building contents:

A new system is currentiy being installed in the Central Fire Station ( 100 Area) to provide firefighting information print-outs for every call received from master fire boxes. This will circumvent the need for having pre-fire plans at the scene. However, it will not be completed for sometime.

\section{Evaluation of Cause}

The investigating committee considered the following as potential causes to the autoignition incident. Each of these was then investigated in detail:
a. Variation in standard billet casting practice requirements by Operations personnel.
b. Inadequate process specifications and operating procedures.
c. Inadequate casting/curing process requirements. a. Variation in standard billet casting practice requirements by Operations
personnel.

Casting variables, such as mix time and the amounts of water and concrete used, are very important to the process in assuring properly cured

billets for shipment. From interviews with Operations personnel, some variability occurs in these factors during the casting operation. No evidence was uncovered which would indicate an obvious variation in standard practice requirements for these variables during the casting campaign in question, but the possibility exists that some of these recommended practices were varied.

Wooden pallets were employed to hold the billets during the curing cycle. Use of the wooden pallets was intended to be for interium billet storage only (due to a shortage of available metal pallets). However, they were inadvertently placed in $303 \mathrm{~K}$ for the high temperature curing cycle. In any event, the use of wooden pallets to hold billets is a deviation from procedures and standard practice. It has not occurred previously.

Although the operators were cooperative and seemed to be conscientious about their jobs, they did not appear to appreciate the importance of all casting process requirements. A number of operators considered their training to be insufficient for the responsibilities they had in this area. The deficiencies in specifications and procedures (discussed in b, below) may have contributed to this. 
UO Investigation Committee Report - U0 82-05

Page. 3

The casting campaigr. which involved these billets being cured in $303 \mathrm{~K}$ was the first campaign which was not directly overviewed by the cognizant process engineer since the current process was developed in 1980. There was also no direct, continuous supervision available through Operations management, and no adequate means of verifying all process parameters.

b. Inadequate process specifications and operating procedures.

In review of the process specifications (DUN-5601, Manufacturing Process Specifications) and the operating procedure (UNI-M-57, No. 4-SP-534, Materials Operating Procedures), and from interviews with Operations personnel, it became apparent that the range of critical process variables was too wide to be useful as a controlling mechanism for the process. The variables were established at an early stage of development of the casting process, so were specified quite broad to cover all contingencies. Actual casting practices have been refined and established through direction of the cognizant engineer, but the specifications and procedures had not been modified to reflect these more stringent 1 imitations.

The procedure needs to be refined as to quantities of materials used in the process, and in several other areas for clarification.

c. Inadequate casting/curing process requirements.

The adequacy of the process requirements was evaluated as established from the major testing program conducted in 1979-1980 (UNI-1454). This document, and subsequent correspondence to DOE-RL refers to the curing process variables as a "burning test" in order to assure safety of the billets for subsequerit cross-country shipment. The process subjects the billets to temperatures greater than those considered possible in shipment. As such, the $303 \mathrm{~K}$ facility is set up to contain billet fires, should they occur. (For this reason, all combustible materials are excluded from $303 \mathrm{~K}$ by procedure.) Therefore, although a fire in the $303 \mathrm{~K}$ must be considered unusual, it is not totally unexpected nor is it an indication of a defective curing process.

A total of approximately 1,650 concreted uranium billets have been cast or cured using the current process since it was established in 1980 , and no other fires have occurred in the 1980-1982 time frame. These billets include 1,030 cast into metal cans and 620 cast into plastic cans.

Nothing was uncovered in the investigation which implies that the casting/ curing process requirements are inadequate. It must be recognized, however, that there is some risk of a billet fire in $303 \mathrm{~K}$ during the curing cycle.

Permanent Corrective Actions

1. DUN-5601, Manufacturing Process Specifications and UNI-M-57, Materials Operating Procedures, will be revised to reflect current accepted casting practice limits and in general to clarify requirements: T. A. Galioto, Fuels Engineering: April 30, 1982. J. W. Bloom, Fuels Operations: May $30,1982$. 
DOE/RL-90-04

UO Investigation Committee Report - U0 82-05

Page 4

2. All Operations personnel involved in the concretion process (curing, casting, storage, shipment) will be re-trained in the process requirements and the importance of these requirements: J. W. Bloom, Fuels Operations: June 15, 1982.

3. A detailed batch preparation sheet will be used for all uranium concretion activities which will specify the limits of the significant process steps. J. W. Bloom, Fuels Operations: May 30, 1982.

4. Fuels Quality Assurance will establish a program for greater frequency and depths of audits to assure that concretion operation requirements are being observed: S. E. Walker, Fuels Quality Assurance: April 15, 1982.

5. All concreted uranium billets cast in the batch located now in 303K (.95\%) and in $304(1.25 \%)$ are suspect to similar processing inadequacies as the billets which autoignited. These will require special handling during curing, including:

a. Spacing of billets on metal pallets so they do not contact adjacent billets during curing in the 303K Building.

b. The billets now in $303 \mathrm{~K}$ must complete the entire high temperature $\left(>135^{\circ} \mathrm{F}\right.$ ) curing cycle again (10 days) prior to release. The billets now in 304 will go through the entire curing cycle as normal: J. W. Bloom, Fuels Operation; initiate by May 1, 1982.

6. Rockwell needs to place more emphas is on safety/contamination aspects of fighting fires within radiation zones (dress/undress proceduras, removal of burning material from fire zones). This will be accomplished by Rockwell through review of established formal training/re-training program: D. E. Good, Rockwell Fire Department: April 30, 1982.

7. Rockwell will assure that available pre-fire plans are posted at each building and at the nearest master fire box for all 300 Area buildings:

D. E. Good, Rockwell Fire Department: April 30, 1982.

8. UNC will have the current concretion process reviewed by an independent consultant to identify potential improvements: T. A. Galioto, Fuels Engineering; July $30,1982$.

9. UNC will verify with HEDL that all appropriate procedures were followed and all action were correct in regard to their involvenent in the $303 \mathrm{~K}$ fire:

T. A. Galioto, Fuels Engineering; April 30, 1982. 
DOE/RL-90-04, Rev. 2

$12 / 15 / 93$

\section{APPENDIX D}

MATERIAL SAFETY DATA SHEETS 
DOE/RL-90-04, Rev. 2

$12 / 15 / 93$

This page intentionally left blank. 


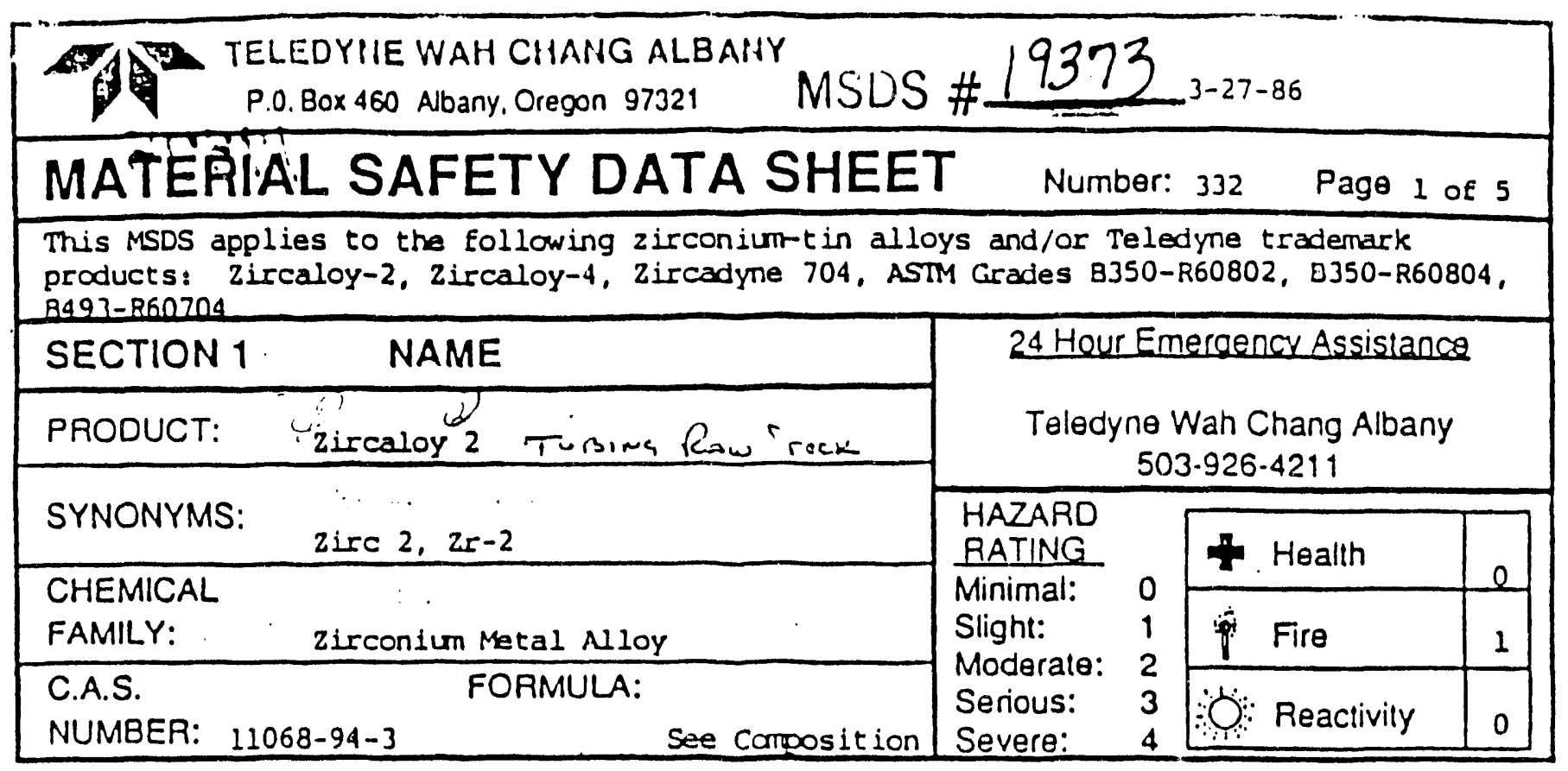

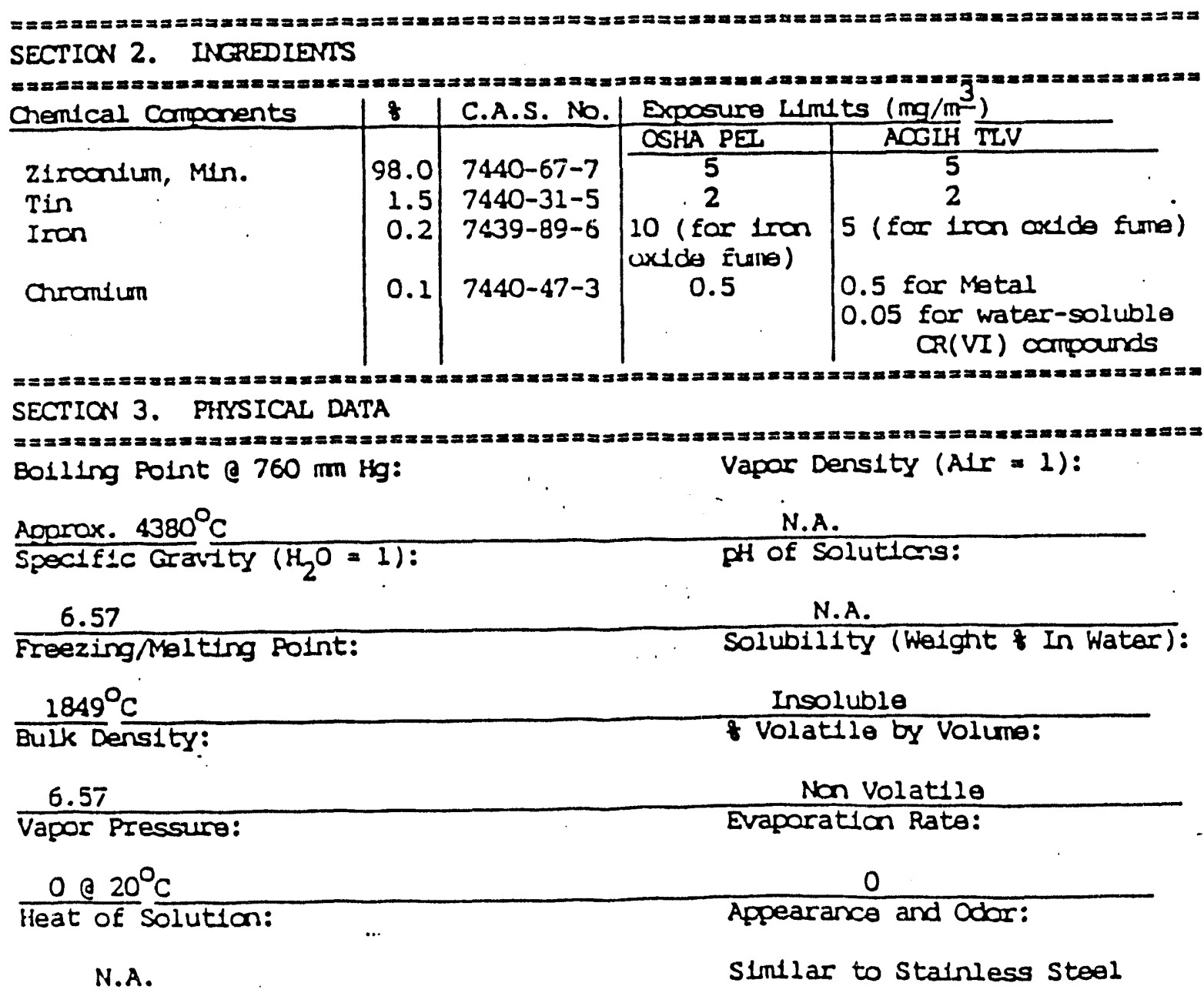


DOE/RL-90-04

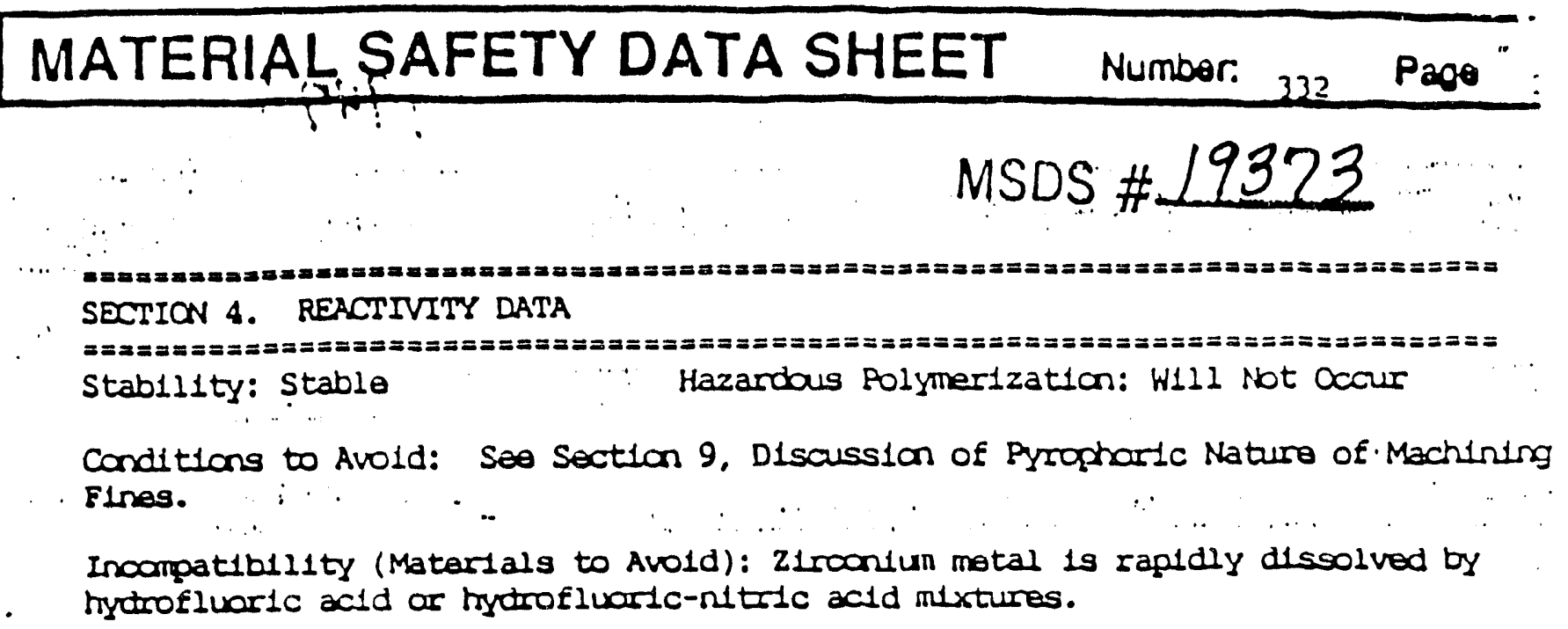

Above $200^{\circ} \mathrm{C}$, zirocontum reacts exothemically with halogen gases, fluarliniu chlorts braning lodine, and halocartons, including carbon totrachlorlde, Freans and Teflon

Nitryl Fluarlde, $\mathrm{NO}_{2}$. w1ll indtiate a reaction with zlroonlum metal at room temperature to produce a glowing or white incandescence.

Hazardous Decamposition Products: 21roontum metal does not decompose. The above reactions with incompatible materials will gererate hazardous reaction products su as flamable tydrogen, toxic fumes of nitrogen axides, or corcoelve ziroontum hall vapors.

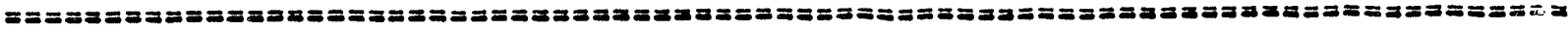
SECTION 5. FIRE AND EXPLOSION HAZARD DATA

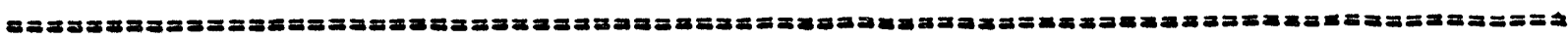
Flash Point and Mothods Used: Solld metal w111 not 1gntte. High surface area mate such as 10 micron pouder may auto 1 gnito at roon temperature.

Flamable Limite in Alr ( \& by Volumo): N.A.

Extinquishing Media: Dry table salt. Type D flro extingulsher.

Fire fighting Procedures: If motal flnas become ignited it is advisable to allow tr. material to bum out. Fires can be controlled by smothering with dry table salt or using Typo D dy-powder fire extingulsining matarlal.

Unusual Fire and Explosion Hazards: Do not spray water on burning ziroonium. Carbo dioxide is not effective in extingutshing burning ziroonitum.

If a fire starts in a mass of wot metal fines, the infitial fire may bo followed by : explosion. Therefore, when in doubt, persannel should ret1re and not attempt to extinguish the fire. The explosive characteristic of such materlal is caused by the stean and hyctrogen generated within the burning mass. 


\section{LINTERIAL SAFEIY UA I SHELI Number: 332 Page 3 of 5

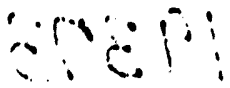 Zircaloy 2

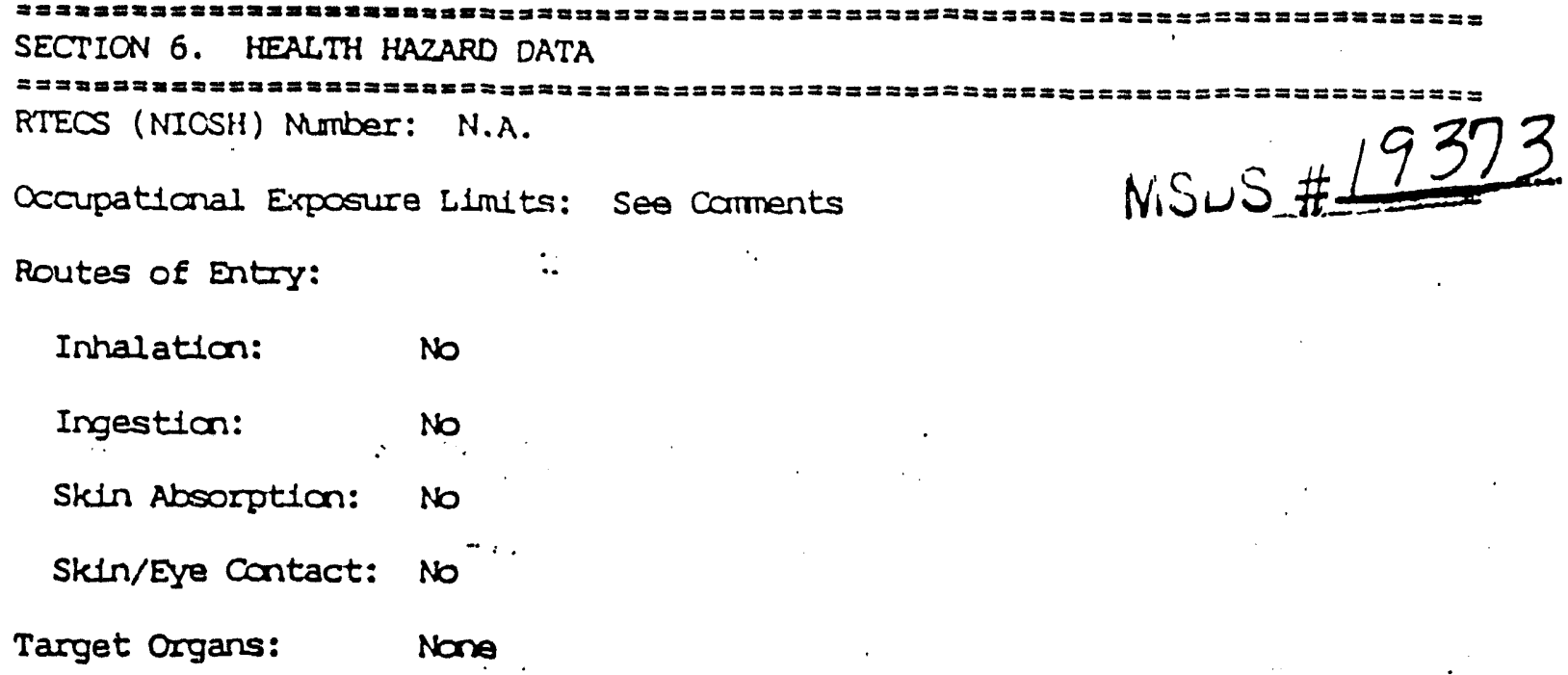 \\ Toxicity Data: As a ziroonium alloy, this material is non-toxic: zircontum metal is mon-taxic, and the chramium is dissolved in the ziroontum matrix and does not exist as free chranium.}

If the alloy is dissolved, vaporlzed or otherwise treated to release the alloying agents in chemically active form, then handling of such material should take. into consideration the possible carcinogentcity of some chromium (VI) compounds.

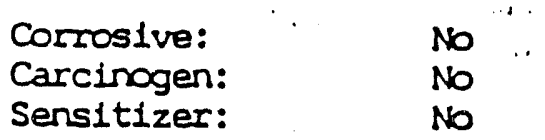

Comments: As a result of studies covering several ziroonilum compands, zircontum was concluded to be an element $t_{3}$ of low toxicity. A value of $5 \mathrm{mg}$ and $10 \mathrm{mg} z$ irconium (in zirconium compounds) per $\mathrm{m}^{3}$ were therefore recommended as the TLV and STEL, respectively.

Acute Effects from Exposure: None

Chranic Effects from Exposure: None

References:

AC/GIH - Documentation of the Threshold Limlt Values.

NIOSH/OSHA - Occupational Health Quldelines for OHenical Hazards.

ILO - Encyclopedia of Occupational Health and Safety.

Patty's Industrlal Ifygiene and Toxtoology, 3rd Ed., Vol. 2A 


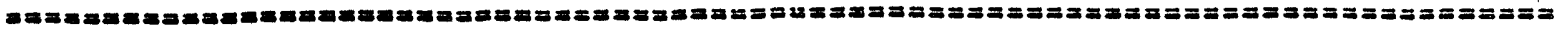
SECTION 7. EMERCENCY AND FIRST AID PROCEDURES

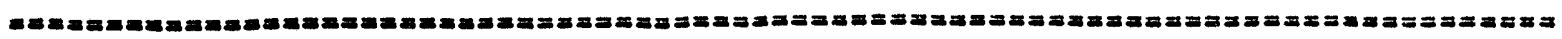
Itipalatelos: N.A.

Eye Contact: Nomal procedure for foralgn object.

Skin Contact: N.A.

Ingestion: N.A.

Notes to Phystcian (Including Antidotes): No speclal procectures.

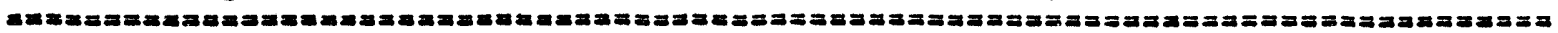
SECTION 8. EMPLOYEE PROTDCTION

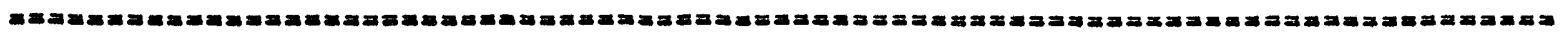
Resplratory Protection: N.A.

Protective Clothing: Use of gloves advisable to avold cuts.

Eyo Protection: N.A.

Add1tional Protective Masures: N.A.

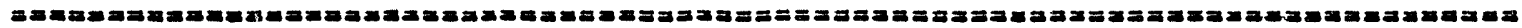
SECTION 9. SPECIAL PROCDDURES

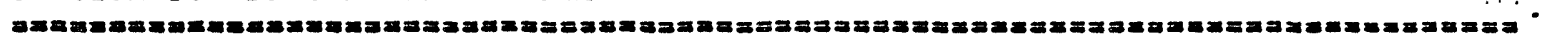
Preciautions to bo Taken During Mandling and Starago: Machlinting of ziroontun may result in fine turnings, chlpo ar dust. Any materlal with a dimenstan less than 0.002 inch $1 \mathrm{~s}$ pyrophorlc, keep away from arry sorrce of ignition.

Keep fine turnings completely dry, ar vary wot. If wet, the water content should to more than 258 by weight for maximum safety in handling. Severe explostons can result from ignition of ziroontum powder or machining fires contalning molsture in the concentration range of 5 to 108 .

Other Procautions: Do not accumulato large quantitles of flnes or machinding residues. Dispose of these materlals dally.

In some cases, when the chemical corrosion resistance of ziroanilum is exceeded, a corrosion product contalning fire ziroonium particulate can form on the surface of the metal which can be easily 1gnitad. Inls film gan be rendered non-flamable by simple oxidation treatments such as heating to $250^{\circ} \mathrm{C}$ for 1 hour or $100^{\circ} \mathrm{C}$ for 8 hours. Ref: Yau, T-L.. "Methods to Treat Pyroghorle F1lm an 21 roconlum" Indistrial

Applications of T1tanlum and 21roanlum: Trind Conference. ASTI STP 830, 1984, pp 124-129.

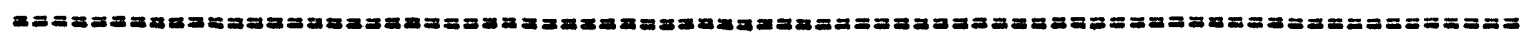

SECTION 10. ENIROMMENTAL PROTECTION

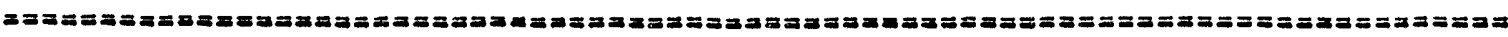

Splll or Leak Procectures: No speclal procodure.

Waste Disposal: Fine, non-recyclable scrap should be burned in small quantities under controlled conditions. The resulting ziroonilum oxide is linert and may bo deposited in a landf1ll.

Envtromental Hazands: Nons 


\section{ivATERIAL SAFETY DATA SHEET $\quad$ Number: 332 Page 5 of 5}

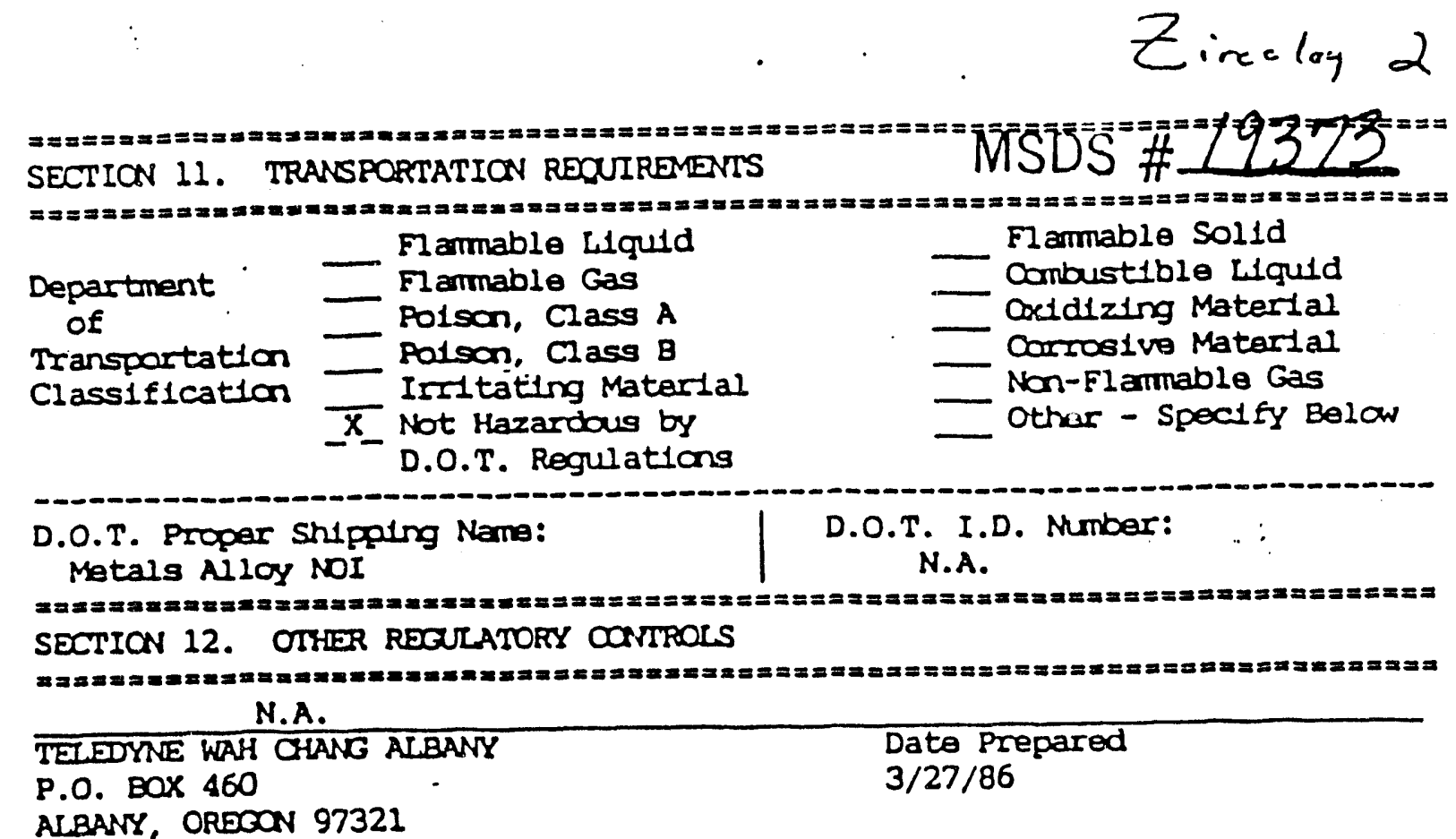


OCLUPATIONAL HEALTH SERVICES, INC.

450 SEVENTH AVENUE, SUITE 2407

EMERGENCY CONTACT:

NEW YORK, NEW YORK' 10123

JOHN S. BRANSFORD, JR. (615) 292-1180

(800) 445 -MSDS

(212) $967-1100$

SUBSTANCE IDENTIFICATION

CAS - NUMBER 7440-61-1

SUBSTANCE: URANIUM

RTEC-NUMBER YR3490000

TRADE HAMES/SYNONYMS:

URANIUM, PYROPHORIC: URANIUM I: URANIUM METAL, PYROPHORIC: URANIUM

238:- U-238: STCC 4926186: NA 9175: OHS24610

CHEMICAL FAMILY:

METAL: RADIOACTIVE

MOLECULAR FORMULA: U MOLECULAR WEIGHT: (238)

CERCLA RATINGS (SCALE 0-3): HEALTH=U FIRE $=3$ REACTIVITY $=3$ PERSISTENCE $=3$ NFPA RATINGS (SCALE 0-4): HEALTH $=U$ FIRE $=3$ REACTIVITY $=3$

COMPONENTS AND CONTAMINANTS

COMPONENT: URANIUM

PERCENT: 100

OTHER CONTAMINANTS: NONE

EXPOSURE LIMIT:

URANIUM:

0.25 MG/M3 OSHA TWA

$0.2 \mathrm{MG} / \mathrm{M} 3 \mathrm{ACGIH}$ TWA; $0.6 \mathrm{MG} / \mathrm{M} 3$ ACGIH STEL

$0.2 \mathrm{MG} / \mathrm{M} 3 \mathrm{MSHA}$ TWA.

OSHA PERMISSIBLE IONIZING RADIATION EXPOSURE IN REMS PER CALENDAR QUARTER AS SET FORTH IN 29CFR1910.96.

OVER 18 YEARS OF AGE

WHOLE BODY: HEAD AND TRUNK; ACTIVE

BLOOD-FORMING ORGANS; LENS OF EYES; $1.25^{*}$

OR GONADS

HANDS AND FOREARMS; FEET AND ANKLES

$18.75^{\star}$

SKIN OF WHOLE BODY

$7.5^{*}$

* UNDER THE AGE OF 18 YEARS A DOSE IN EXCESS OF 10 PERCENT OF THE LIMITS SPECIFIED SHALL NOT BE PERMITTED.

THE PERMISSIBLE WHOLE BODY EXPOSURE, FOR INDIVIDUALS AT LEAST 18 YEARS OF AGE, MAY BE EXCEEDED PROVIDED ALL OF THE FOLLOWING PROVISIONS ARE MET:

(1) THE DOSE SHALL NOT EXCEED 3 REMS DURING ANY CALENDAR QUARTER.

(2) THE TOTAL ACCUMULATED OCCUPATIONAL DOSE TO THE WHOLE BODY SHALL NOT EXCEED $5(N-18)$ REMS, WHERE " $N$ " EQUALS THE INDIVIDUAL'S AGE IN YEARS AT HIS LAST 
OF ALPHA PARTICLES PRODUCES SERIOUS BIOLOGICAL DAMAGE IN THE TISSUES WITH WHICH THE PARTICLES INTERACT.

DUE TO THE HIGH ENERGY LEVELS, INTERNALLY DEPOSITED ALPHA EMITTERS WILL KILL CELLS IMMEDIATELY ADJACENT TO THE SOURCE. CELLS DAMAGED MAY NOT RECOVER OR BE REPAIRED. THE SPECIFIC EFFECTS OF ALPHA EMITTERS WILL DEPEND ON THEIR CHEMICAL CHARACTERISTICS. EACH ISOTOPE WILL FOLLOW A FAIRLY SPECIFIC BIOLOGICAL PATHWAY IN THE BODY. SOME ISOTOPES ARE CONCENTRATED OR RETAINED IN A SPECIFIC ORGAN OR TISSUE; RATES OF ELIMINATION VARY CONSIDERABLY.

FOLLOWING INHALATION, ALPHA EMITTERS MAY OR MAY NOT BE ABSORBED, DEPENDING ON SOLUBILITY. INSOLUBLE MATERIALS MAY REMAIN AT OR NEAR THE SITE OF DEPOSITION, AND CONSTITUTE AN INTERNAL RADIATION HAZARD. FOR INSTANCE, AN INSOLUBLE ALPHA EMITTER, INHALED AS AN AEROSOL, WILL BE DEPOSITED ALONG THE TRACHEOBRONCHIAL TREE. HEAVIER PARTICLES WILL BE BROUGHT UP TO THE THROAT BY CILIARY ACTION, AND MAY THEN BE SWALLOWED. THE LIGHTER PARTICLES MAY BE LODGED DEEP IN THE ALVEOLAR AIR SACS AND REMAIN. THIS RETAINED MATERIAL MAY PRESENT A HAZARD TO THE LUNG. A PORTION OF THIS RETAINED MATERIAL MAY BE PICKED UP BY THE LYMPHATIC SYSTEM DRAINING THE PULMONARY REGION, AND BE STORED IN THE LYMPH NODES OF THE LUNGS.

A SOLUBLE ALPHA EMITTER, WHEN INHALED, MAY RAPIDLY ENTER THE BLOODSTREAM AND SEEK A PARTICULAR ORGAN OR TISSUE, OR BECOME ELIMINATED IN EITHER THE URINE OR FECES. THE DAMAGE DUE TO THESE RADIOACTIVE COMPOUNDS DEPENDS ON HOW QUICKLY THEY ARE ELIMINATED, AND THE SUSCEPTIBILITY OF THE TISSUE IN WHICH THEY ARE STORED. A SINGLE LARGE DOSE OF RADIATION MAY LEAD TO RADIATION SICXNESS.

CHRONIC EXPOSURE- THE EFFECTS OF CHRONIC EXPOSURE BY INTERNALLY DEPOSITED ALPHA RADIATION IS DEPENDENT UPON THE DOSE AND TARGET ORGAN(S). THE EFFECTS OF INTERNAL SOURCES ARE NOT LIKELY TO CORRESPOND TO THE EFFECTS OF COMPARABLE DOSES OF PARTIAL BODY EXTERNAL IRRADIATION. A POSSIBLE PHENOMENON, PECULIAR TO INTERNAL EMITTERS, IS THE TRANSMUTATION EFFECT. MANY RADIONUCLIDES MAY BE INCORPORATED IN ESSENTIAL BIOLOGICAL MOLECULES LEADING TO THE FOLLOWING EFFECTS WHEN THEY DECAY: (1) ENERGY DEPOSITION FROM THE RADIOACTIVE PROCESS, (2) MOLECULAR DISRUPTION DUE TO POSSIBLE RECOIL EFFECTS, AND (3) MOLECULAR DISORIENTATION AS A RESULT OF NUCLEAR TRANSMUTATION. AS AN EXAMPLE OF THE THIRD CASE, A BIOLOGICAL MOLECULE SUCH AS DNA MAY BE DISRUPTED WHEN A RADIOACTIVE ELEMENT INCORPORATED IN IT DECAYS TO A DIFFERENT ELEMENT NOT NORMALLY FOUND IN DNA. IN SUCH A CASE, A POINT MUTATION WOULD OCCUR. MUTATIONS ARE USUALLY DELETERIOUS.

IN GENERAL, THE EFFECTS OF CHRONIC ALPHA IRRADIATION ARE DIFFICULT TO QUANTIFY. SOME POSSIBLE OISORDERS INCLUDE LUNG C.ANCER, STERILITY, ANEMIA, LEUKEMIA OR BONE CANCER. IF THE TOTAL DOSE OF RADIATION IS SUFFICIENT, RADIATION SICKNESS MAY OCCUR, WITH THE SYMPTOMS DESCRIBED BELOW.

RADIATION SICKNESS

THE SYMPTOMS OF RADIATION SICKNESS ARE DEPENDENT UPON THE DOSE, DOSE RATE, AREA OF THE BODY AFFECTED AND THE TIME AFTER EXPOSURE. RADIATION SICKNESS MAY RESULT FROM INTERNAL OR EXTERNAL SOURCES, AND ACUTE OR CHRONIC EXPOSURE. THE TOTAL DOSE RECEIVED IS THE DETERMINING FACTOR. RADIATION SICKNESS HAS THREE (3) CLEARLY DEFINED SYNDROMES: THE HEMATOPOIETIC, THE GASTROINTESTINAL AND THE CEREBRAL SYNDROMES.

THE HEMATOPOIETIC SYNDROME: THIS SYNDROME MAY OCCUR WHEN DOSAGES OF 200 TO 1000 RADS ARE RECEIVED AS A WHOLE BODY DOSE. IT IS CHARACTERIZED BY ANOREXIA, APATHY, NAUSEA AND VOMITING, AND MAY BECOME MAXIMAL WITHIN 6 TO 12 HOURS AFTER EXPOSURE. SYMPTOMS THEN SUBSIDE, SO THAT 24 TO 36 HOURS AFTER EXPOSURE THE SUBJECT IS ASYMPTOMATIC. DURING THIS PERIOD OF APPARENT WELL-BEING, THE LYMPH NODES, SPLEEN AND BONE MARROW BEGIN TO ATROPHY. THIS ATROPHY IS THE RESULT OF 2 DISTINCT PROCESSES: DIRECT KILLING OF RADIOSENSITIVE CELLS AND INHIBITION OF NEW CELL PRODUCTION. IN 
THE PERIPHERAL BLOOD, LYMPHOPENIA COMMENCES IMMEDIATELY, BECOMING MAXIMAL WITHIN 24 TO 36 HOURS. NEUTROPENIA DEVELOPS MORE SLOWLY. THROMBOCYTOPENIA MAY BE PROMINENT WITHIN 3 TO 4 WEEKS. IF THE BONE MARROW DEPRESSION PROGRESSES TO A CRITICAL LEVEL SUCH THAT THE VICTIM IS NOT ABLE TO SEND SUFFICIENT NUMBERS OF GRANULOCYTES AND THROMBOCYTES TO THE CIRCULATING BLOOD, DEATH FROM OVERWHELMING INFECTION MAY OCCUR.

THE GASTROINTESTINAL TYNDROME: THIS SYNDROME OCCURS WHEN 400 OR MORE RADS r RE RECEIVED AS A WHOLE BODY DOSE. IT IS CHARACTERIZED BY INTRACTABLE N. USEA, VOMITING AND DIARRHEA THAT MAY LEAD TO SEVERE DEHYDRATION, DIMINISHED PLASMA VOLUME, VASCULAR COLLAPSE AND DEATH. THE GASTROINTESTINAL SYNDROME RESULTS FROM THE INITIAL "TOXEMIA" DUE TO NECROSIS OF TISSUE AND IS PERPETUATED BY PROGRESSIVE ATROPHY OF THE GASTRCINTESTINAL MUCOSA. ULTIMATELY THE INTESTINAL VILLI ARE DENUDED, WITH MASSIVE LOSS OF PLASMA INTO THE INTESTINE. REGENERATION OF INTESTINAL EPITHELIAL CELLS MAY BE POSSIBLE AFTER LARGE DOSES OF RADIATION; MASSIVE PLASMA REPLACEMENT AND ANTIBIOTICS DURING THE FIRST 4 TO 6 DAYS MAY KEEP THE PATIENT ALIVE UNTIL THE EPITHELIUM REGENERATES. HOWEVER, EVEN IF THE PATIENT SURVIVES, THE RESPITE MAY BE TEMPORARY, SINCE HEMÁTOPOIETIC FAILURE MAY ENSUE, COMMENCING WITHIN 2 OR 3 WEEKS.

WITH ACUTE TOTAL BODY RADIATION DOSES OF >600 RADS, HEMATOPOIETIC OR GASTROINTESTINAL MALFUNCTION MAY BE FATAL. WITH RADIATION DOSES OF $<600$ RADS, THE POSSIBILITY OF SURVIVAL IS INVERSELY RELATED TO THE TOTAL DOSE.

THE CEREBRAL SYNDROME: THIS SYNDROME IS PRODUCED BY EXTREMELY HIGH TOTAL BODY DOSES OF RADIATION, USUALLY $>3000$ RADS, AND GENERALLY CAUSES

OEATH. IT CONSISTS OF 3 PHASES: A PRODROMAL PERIOD OF NAUSEA AND VOMITING;

THEN LISTLESSNESS AND DROWSINESS RANGING FROM APATHY TO PROSTRATION, POSSIBLY CAUSED BY NON-BACTERIAL INFLAMMATION FOCI OF THE BRAIN OR THE EFFECTS OF RADIATION-INDUCED TOXIC PRODUCTS; AND FINALLY, A MORE GENERALIZED COMPONENT CHARACTERIZED BY TREMORS, CONVULSIONS, ATAXIA AND DEATH WITHIN A FEW HOURS.

OTHER ACUTE EFFECTS:

THE SKIN IS MORE SUBJECT TO RADIATION EXPOSURE ESPECIALLY TO BETA OR X-RAYS THAN OTHER TISSUE. A SLIGHT EXPOSURE CAN RESULT IN ERYTHEMA, CHANGES IN PIGMENTATION, EPILATION, BLISTERING, NECROSIS, AND ULCERATION. THE GONADS ARE ALSO PARTICULARILY RADIOSENSITIVE. A SINGLE DOSE OF 30 RADS RESULTS IN TEMPORARY STERILITY AMONG MEN. IN WOMEN, LOSS OF FERTILITY IS INDICATED BY LOSS OF MENSTRUATION. THE EYES ARE ALSO VERY RADIOSENSITIVE; A SINGLE DOSE OF 100 RADS MAY CAUSE CONJUNCTIVITIS AND KERATITIS.

DELAYED OR CHRONIC EFFECTS OF RADIATION SICKNESS:

THE DELAYED EFFECTS OF RADIATION MAY BE DUE EITHER TO A SINGLE LARGE OVEREXPOSURE OR CONTINUING LOW-LEVEL OVEREXPOSURE. AMONG THE DELAYED EFFECTS ARE CANCER, GENETIC EFFECTS, SHORTENING OF LIFE SPAN, AND CATARACTS. RADIATION-INDUCED CANCER IS OBSERVED MOST FREQUENTLY IN THE HEMOPOIETIC SYSTEM, THYROID, BONE, AND SKIN. LEUKEMIA IS AMONG THE MOST LIKELY FORMS OF MALIGNANCY RESULTING FROM OVEREXPOSURE TO TOTAL BOOY RADIATION. BONE SEEXERS CAN DAMAGE THE RADIOSENSITIVE HEMOPOIETIC TISSUE IN THE BONE MARROW AND THEY ALL PRODUCED CANCER WHEN INJECTED INTO LABORATORY ANIMALS IN SUFFICIENT QUANTITY. LONG TERM CONTINUOUS RADIOACTIVE MATERIALS RESIDING IN THE LUNG MAY PRODUCE CANCER. THE GONADS ARE ALSO PARTICULARILY RADIOSENSITIVE. A SINGLE DOSE OF 30 RADS RESULTS IN TEMPORARY STERILITY AMONG MEN. IN WOMEN, LOSS OF FERTILITY IS INDICATED BY LOSS OF MENSTRUATION.

IONIZING RADIATION IS KNOWN TO PRODUCE A VARIETY OF TYPES OF GENETIC INJURY RANGING FROM POINT MUTATIONS TO SEVERE CHROMOSOME DAMAGE SUCH AS STRAND BREAKAGE, TRANSLOCATIONS, AND DELETIONS. MUTATIONS IN 
SOMATIC CELLS MAY BE RESPONSIBLE, IN PART, FOR THE INITIATION OF RADIOGENIC CANCERS. IF THE GERM CELLS HAVE BEEN AFFECTED, THE EFFECTS OF THE MUTATION MAY NOT BECOME APPARENT UNTIL THE NEXT GENERATION, OR EVEN LATER.

FIRST AID- REMOVE FROM EXPOSURE AREA TO A RESTRICTED AREA WITH FRESH AIR AS QUICKLY AS POSSIBLE. IF BREATHING HAS STOPPED, PERFORM ARTIFICIAL RESPIRATION BY ADMINISTERING OXYGEN; MOUTH-TO-MOUTH RESUSCITATION SHOULD BE AVOIDED, TO PREVENT EXPOSURE TO THE PERSON RENDERING FIRST AID. ANY EVIDENCE OF SERIOUS CONTAMINATION INDICATES THAT TREATMENT MUST BE INSTITUTED. INHALATION OF RADIOACTIVE PARTICLES MAY INDICATE THAT OTHER PARTS OF THE BOOY WERE ALSO CONTAMINATED, SUCH AS THE DIGESTIVE TRACT, SKIN AND EYES. IF TIME PERMITS, WIPE THE FACE WITH WET FILTER PAPER, FORCE COUGHING AND BLOWING OF THE NOSE. GET MEDICAL ATTENTION IMMEDIATELY (INTERNATIONAL ATOMIC ENERGY ASSOCIATION \#3, PG.65). !! WARNING!!

THE VICTIM MAY BE CONTAMINATED WITH RADIOACTIVE PARTICLES. THOROUGH DECONTAMINATION SHOULD BE STARTED BEFORE THE VICTIM IS MOVED TO THE MEDICAL AREA.

ANY PERSONNEL INVOLVED IN RENDERING FIRST AID MUST BE MONITORED FOR RADIOACTIVITY AND THROUGHLY DECONTAMINATED IF NECESSARY (IAEA \#3, PG.65).

SKIN CONTACT:

URANIUM:

RADIOACTIVE.

ACUTE EXPOSURE- THERE IS NO EVIDENCE THAT INSOLUBLE URANIUM COMPOUNDS CAN BE ABSORBED THROUGH THE SKIN; INSOLUBLE SALTS PRODUCED NO SIGNS OF POISONING AFTER SKIN CONTACT. URANIUM MAY IRRITATE THE SKIN.

CHRONIC EXPOSURE- PROLONGED SKIN CONTACT WITH INSOLUBLE URANIUM COMPOUNDS SHOULD BE AVOIDED BECAUSE OF POTENTIAL RADIATION DAMAGE TO BASAL CELLS. DERMATITIS HAS OCCURRED AS A RESULT OF HANDLING SOME INSOLUBLE URANIUM COMPOUNDS. SEE THE FOLLOWING SECTIONS REGARDING ALPHA RADIATION AND RADIATION SICKNESS.

ALPHA RADIATION:

ACUTE EXPOSURE- ALPHA RADIATION IS NOT USUALLY AN EXTERNAL HAZARD. THESE HEAVY PARTICLES DO NOT PENETRATE THE STRATUM CORNEUM OF THE SKIN. THE MAJOR DIFFICULTY ARISES WHEN THE SURFACE OF THE SKIN IS DAMAGED IN SOME WAY. WHEN AN INSOLUBLE ALPHA EMITTER ENTERS A PUNCTURE WOUND, LOCAL CELL DAMAGE AT THE SITE OF THE WOUND MAY OCCUR, THE SEVERITY OF WHICH IS DEPENDENT UPON THE DOSE. ENTRY OF A SOLUBLE ALPHA EMITTER INTO A PUNCTURE WOUND PRESENTS A DANGER OF MORE GENERALIZED CONTAMINATION AS THE ALPHA SOURCE BECOMES SPREAD THROUGH THE BODY. EITHER CASE MAY RESULT IN ALTERATION OF THE GENETIC MATERIAL, CANCER, AND THE OTHER SYMPTOMS OF RADIATION SICKNESS.

CHRONIC EXPOSURE- IF AN ALPHA EMITTER ENTERS THE BODY THROUGH A WOUND AND BECOMES DEPOSITED, THERE IS SOME DANGER THAT ITS CONTINUING DECAY COULD AFFECT THE ORGANS'OR TISSUES IN WHICH IT IS DEPOSITED. ALPHA RADIATION IS VERY DAMAGING; AFFECTED CELLS MAY NOT RECOVER FROM ITS EFFECTS. SUCH LOCALIZED IRRADIATION OF TISSUES MAY RESULT IN GENETIC CHANGES AND MAY SUBSEQUENTLY LEAD TO CANCER, OR OTHER SYMPTOMS OF RADIATION SICKNESS. THE EXACT EFFECTS OF AN INTERNALLY DEPOSITED ALPHA EMITTER DEPENDS ON THE NATURE OF THE ISOTOPE, AND ITS SOLUBILITY.

RADIATION SICKNESS

THE CLINICAL COURSE OF RADIATION SICKNESS DEPENDS UPON THE DOSE, DOSE RATE, AREA OF THE BODY AFFECTED AND TIME AFTER EXPOSURE. EXTERNAL AND INTERNAL RADIOACTIVITY OF ANY TYPE MAY CAUSE RADIATION SICKNESS.

RADIATION SICKNESS HAS THREE (3) CLEARLY DEFINED SYNDROMES WHICH ARE DESCRIBED IN DETAIL IN THE INHALATION SECTION. 


\section{MIDUO $\pi \underline{2329}$}

FIRST AID- REMOVE VICTIM TO A SUITABLE AREA FOR DECONTAMINATION AS QUICKLY AS POSSIBLE. REMOVE CLOTHING AND SHOES IMMEDIATELY. THOROUGHLY WASH THE VICTIM WITH SOAP AND WATER, PAYING PARTICULAR ATTENTION TO THE HEAD, FINGER NAILS AND PALMS OF THE HANDS. UPON COMPLETION OF WASHING, MONITOR THE VICTIM FOR RADIOACTIVITY. IT IS IMPERATIVE THAT THE SKIN SHOULD BE DECONTAMINATED AS QUICKLY AS POSSIBLE. MINUTE SKIN INJURIES GREATLY INCREASE THE DANGER OF ISOTOPE PENETRATION INTO THE VICTIM; SHAVING SHOULD NOT BE ATTEMPTED. IF WATER AND SOAP HAVE BEEN INADEQUATE IN REMOVING THE RADIOACTIVE COMPOUND, DECONTAMINATING COMPOUNDS CONSISTING OF SURFACTANTS AND ABSORBENT SUBSTANCES MAY BE EFFECTIVE. COMPLEXING REAGENTS MAY ALSO BE OF USE. THE USE OF ORGANIC SOLVENTS IS TO BE AVOIDED, AS THEY MAY INCREASE THE SOLUBILITY AND ABSORPTION OF THE RADIOACTIVE SUBSTANCE. SKIN CONTAMINATION WITH RADIATION MAY BE AN INDICATION THAT OTHER PARTS OF THE BODY HAVE BEEN EXPOSED (INTERNATIONAL ATOMIC AGENCY ASSO. \#47 PG.9; INTERNATIONAL ATOMIC ENERGY ASSO. \#3, PG. 62). !! WARNING!! CONTAMINATED CLOTHING MUST BE STORED IN A METAL CONTAINER FOR LATER DECONTAMINATION OR DISPOSAL. THE WATER USED TO WASH THE VICTIM MUST BE STORED IN METAL CONTAINERS FOR LATER DISPOSAL.

ANY PERSONNEL INVOLVED IN RENDERING FIRST AID TO THE VICTIM MUST BE MONITORED FOR RADIOACTIVITY AND DECONTAMINATED IF NECESSARY (IAEA \#47, PG.9; IAEA \#3, PG.62).

EYE CONTACT:

URANIUM:

RADIOACTIVE.

ACUTE EXPOSURE- DUST MAY BE IRRITATING TO THE EYES. A VARIETY OF SOLUBLE AND INSOLUBLE COMPOUNDS OF URANIUM WERE TESTED ON THE EYES OF RABBITS. THE INSOLUBLE COMPOUNDS CAUSED THE MILDEST DEGREE OF INJURY. THE EFFECTS OF EYE CONTACT WITH ANY URANIUM COMPOUND TEND TO BE NECROSIS OF THE CONJUNCTIVAE AND EYELIDS, AND ULCERATION OF THE CORNEA.

CHRONIC EXPOSURE - PROLONGED EXPOSURE TO URANIUM MAY PRODUCE CONJUNCTIVITIS, OR THE SYMPTOMS OF RADIATION INJURY, SUCH AS CATARACTS. SEE THE FOLLOWING SECTIONS REGARDING THE EFFECTS OF ALPHA RADIATION ON THE EYES, AND RADIATION SICKNESS.

ALPHA RADIATION:

ACUTE EXPOSURE- RADIATION AFFECTS THE EYE BY INDUCING ACUTE INFLAMMATION OF THE CONJUNCTIVA AND THE CORNEA. THE MOST SENSITIVE PART OF THE EYE IS THE CRYSTALLINE LENS. A LATE EFFECT OF EYE IRRADIATION IS CATARACT FORMATION. IT MAY BEGIN ANYWHERE FROM 6 MONTHS TO SEVERAL YEARS AFTER A SINGLE EXPOSURE. CATARACT FORMATION BEGINS AT THE POSTERIOR POLE OF THE LENS, AND CONTINUES UNTIL THE ENTIRE LENS HAS BEEN AFFECTED. GROWTH OF THE OPACITY MAY STOP AT ANY POINT. THE RATE OF GROWTH AND THE DEGREE OF OPACITY ARE DEPENDENT UPON THE DOSE OF RADIATION.

CHRONIC EXPOSURE - REPEATED OR PROLONGED EXPOSURE TO ALPHA RADIATION MAY RESULT IN CATARACT FORMATION, AS DESCRIBED ABOVE. OF THE WELL-DOCUMENTED LATE EFFECTS OF RADIATION ON MAN, LEUKEMIA AND CATARACTS HAVE BEEN OBSERVED AT DOSES LOWER THAN THOSE PRODUCING SKIN SCARRING AND CANCER OR BONE TUMORS. THE LENS OF THE EYE SHOULD BE CONSIDERED TO BE A CRITICAL ORGAN.

RADIATION SICKNESS

THE EYES ARE VERY RADIOSENSITIVE; A SINGLE DOSE OF 100 RADS MAY CAUSE CONJUNCTIVITIS AND KERATITIS

IT IS UNLIKELY THAT A DOSE SUH ICIENT TO CAUSE RADIATION SICKNESS WOULD OCCUR IF ONLY THE EYES WERE IRRADIATED. HOWEVER, IF EYE DAMAGE BY IONIZING RADIATION OCCURS, IT MAY BE BEST TO ASSUME THAT OTHEK PARTS OF THE BODY HAVE 
DOE/RL-90-04

ALSU BEEN CONTAMINATED. SYMPTOMS OF RADIATION SICKNESS ARE DESCRIBED IN THE INHALATION SECTION.

\section{MSDS \#2329}

FIRST AID- REMOVE VICTIM TO A RESTRICTED AREA FOR DECONTAMINATION. THOROUGHLY WASH EYES WITH LARGE AMOUNTS OF WATER, OCCASIONALLY LIFTING THE THE UPPER AND LOWER LIDS (APPROXIMATELY 15 MINUTES). FOLLOWING THE WATER TREATMENT, PROVIDE AN ISOTONIC SOLUTION. DO NOT USE EYEBATHS, RATHER PROVIDE A CONTINUOUS AND COPIOUS SUPPLY OF FLUID. MONITOR THE VICTIM FOR RADIOACTIVITY. IF ACTIVITY IS PRESENT, REWASH THE EYES, AND REMONITOR UNTIL LITTLE OR NO RADIOACTIVITY IS PRESENT. GET MEDICAL ATTENTION IMMEDIATELY (INTERNATIONAL ATOMIC ENERGY ASSO. \#3, PG.65; $\# 47, P G .35$ ).

!! WARNING!!

ANY WATER USED TO WASH THE VICTIMS EYES MUST BE STORED IN A METAL CONTAINER FOR LATER DISPOSAL. ANY OTHER ARTICLES THAT ARE USED TO DECONTAMINATE THE VICTIM MUST ALSO BE STORED IN METAL CONTAINERS FOR LATER DECONTAMINATION OR DISPOSAL. ANY PERSONNEL INVOLVED IN RENDERING FIRST AID TO THE VICTIM MUST BE MONI?) RED FOR RADIOACTIVITY AND DECONTAMINATED IF NECESSARY (IAEA \#3, PG.65; \#47, PG.35).

INGESTION:

URANIUM:

RADIOACTIVE/NEPHROTOXIN.

ACUTE EXPOSURE- FEEDING STUDIES ON ANIMALS INDICATE THAT INSOLUBLE URANIUM IS MUCH LESS TOXIC THAN SOLUBLE URANIUM COMPOUNDS. URANIUM ENTERING THE BLOODSTREAM WILL BECOME STORED IN THE BONE MARROW, BUT THE MAJORITY WILL BECOME LODGED IN THE KIDNEY, WHICH IS THE MAJOR SITE OF TOXICITY. MORE THAN A YEAR AND A HALF IS REQUIRED TO RID THE BODY OF AN ACCIDENTAL HIGH DOSE OF URANIUM, AFTER WHICH TIME MEASURABLE URANIUM IS PRESENT IN THE BONE AND KIDNEY.

CHRONIC EXPOSURE- THE TOXIC ACTION OF URANIUM RESIDES MORE IN ITS CHEMICAL ACTION ON THE RENAL TUBULES, RATHER THAN RADIATION EFFECTS. RATS INJECTED WITH URANIUM METAL IN THE FEMORAL MARROW DEVELOPED SARCOMAS, WHETHER THIS WAS DUE TO METALLOCARCINOGENIC OR RADIOCARC INOGENIC CATION COULD NOT BE DETERMINED. SEE THE FOLLOWING SECTIONS REGARDING INGESTION OF ALPHA EMITTERS, AND RADIATION SICKNESS. ALSO SEE THE FIRST AID SECTION FOR URANIUM COMPOUNDS.

ALPHA RADIATION:

ACUTE EXPOSURE - THE FATE OF INGESTED ALPHA EMITTERS DEPENDS ON THEIR SOLUBILITY AND VALENCE. ONCE INSIDE THE BODY, RADIONUCLIDES ARE ABSORBED, METABOLIZED, AND DISTRIBUTED THROUGHOUT THE TISSUES AND ORGANS ACCORDING TO THE CHEMICAL PROPERTIES OF THE ELEMENTS AND COMPOUNDS IN WHICH THEY EXIST. THEIR EFFECTS ON ORGANS OR TISSUES DEPEND ON THE TYPE AND ENERGY OF THE RADIATION AND RESIDENCE TIME.

RADIOACTIVE ISOTOPES ARE ELIMINATED FROM THE BODY THROUGH VARIOUS CHANNELS. ISOTOPES THAT ARE OF LITTLE OR NO SOLUBILITY ARE ELIMINATED THROUGH THE LIVER AND DIGESTIVE SYSTEM. SOLUBLE ISOTOPES WHICH HAVE BEEN ABSORBED INTO THE BODY ARE ELIMINATED IN THE URINE. ISOTOPES ARE MOST READILY REMOVED FROM NERVE AND MUSCLE TISSUE, AND MUCH MORE SLOWLY FROM THE KIDNEYS AND THE CELLS OF THE RETICULO-ENDOTHELIAL SYSTEM, AND MOST SLOWLY OF ALL FROM THE BONES. IN THE LYMPH NODES, RADIOACTIVE ISOTOPES ARE RETAINED FOR A COMPARITIVELY LONG PERIOD. PHYSIOLOGICAL CONDITION ANO AGE OF THE PERSON, AS WELL AS THE TOTAL QUANTITY OF THE ISOTOPES DETERMINES THE ELIMINATION RATE. 
WHILE BEING ELIMINATED, ALPHA EMITTERS MAY DECAY, IRRADIATING THE TISSUE ALONG ANY OF THE ABOVE ELIMINATION ROUTES WITH HIGH ENERGY RADIATION. THE EXTENT TO WHICH THIS OCCURS IS DEPENDENT UPON THE PHYSICAL AND BIOLOGICAL HALF-LIFE OF THE RADIONUCLEOTIDE. HIGH DOSES OF RADIATION DELIVERED TO ANY TISSUE WILL RESULT IN DAMAGE, AND MAY LEAD TO THE SYMPTOMS OF RADIATION SICKNESS, OR THE LONG TERM EFFECTS DESCRIBED IN THE SECTION ON RADIATION SICKNESS.

CHRONIC EXPOSURE- REPEATED OR PROLONGED INGESTION OF ALPHA EMITTERS MAY LEAD TO RADIATION SICKNESS, OR DELAYED EFFECTS OF RADIATION EXPOSURE, AS DESCRIBED IN THAT SECTION.

RADIATION SICKNESS

THE SYMPTOMS OF RADIATION SICKNESS DEPENDS UPON THE DOSE RECEIVED. IT MAY RESULT FROM ACUTE OR CHRONIC EXPOSURE TO ANY FORM OF RADIATION. THE SYMPTOMS ARE DESCRIBED IN THE INHALATION SECTION.

FIRST AID FOR URANIUM COMPOUNDS:

ALTHOUGH CHELATING AGENTS ACT ON URANIUM, THEY SHOULD NOT BE USED BECAUSE THE INCREASED MIGRANT FRACTION LEADS THROUGH RENAL PRECIPITATION TO A GREATER KIDNEY BURDEN THAN WOULD BE RECEIVED IF THERE WERE NO TREATMENT AT ALL; THERE IS THUS THE RISK OF SERIOUS TOXIC NEPHRITIS. THE BASIC TREATMENT SHOULD BE ADMINISTRATION OF A BICARBONATED SOLUTION GIVEN LOCALLY AND IN INTRAVENOUS PERFUSION (ONE BOTTLE OF $250 \mathrm{ML}$ AT $1.4 \%$ ). FROM IAEA SAFETY SERIES \# 47 - MANUAL ON EARLY MEDICAL TREATMENT OF POSSIBLE RADIATION MNUUYKY - 1978. PG. 28.

FIRST AID: IN THE CASE OF INGESTION OF RADIOACTIVE SUBSTANCES, THE MOUTH SHOULD BE RINSED OUT IMMEDIATELY AFTER THE ACCIDENT, CARE BEING TAKEN NOT TO SWALLOW THE WATER USED FOR THIS PURPOSE. VOMITING SHOULD BE INDUCED EITHER MECHANICALLY, OR WITH SYRUP OF IPECAC. DO NOT INDUCE VOMITING IN AN UNCONSCIOUS PERSON. LAVAGE MAY BE USEFUL. CARE SHOULD BE TAKEN TO AVOID ASPIRATION. THE VOMITUS AND LAVAGE FLUIDS SHOULD BE SAVED FOR EXAMINATION AND MONITORING. FURTHER ACTION DEPENDS ON THE NATURE OF THE RADIOACTIVE SUBSTANCE. GET MEDICAL ATTENTION IMMEDIATELY (INTERNATIONAL ATOMIC ENERGY ASSO. \#47, PG.9; \#3, PP.59 AND 66).

!!WARNING!!

THE GASTRIC FLUIDS AND FLUIOS USED FOR LAVAGE MUST BE STORED IN METAL CONTAINERS FOR LATER DISPOSAL. THE VICTIM MUST BE MONITORED FOR RADIOACTIVITY AND DECONTAMINATED, IF NECESSARY, BEFORE BEING TRANSPORTED TO A MEDICAL FACILITY. ANY PERSONNEL INVOLVED IN RENDERING FIRST AID TO THE VICTIM MUST BE MONITORED FOR RADIOACTIVITY AND DECONTAMINATED IF NECESSARY (IAEA \#47, PG.9; \#3, PP. 59 AND 66).

ANTIDOTE :

THE FOLLOWING ANTIDOTE HAS BEEN RECOMMENDED. HOWEVER, THE DECISION AS TO WHETHER THE SEVERITY OF POISONING REQUIRES ACMINISTRATION OF ANY ANTIDOTE AND ACTUAL DOSE REQUIRED SHOULD BE MADE BY QUALIFIED MEDICAL PERSONNEL.

THERE IS NO ANTIDOTE FOR RADIATION SICKNESS. TREATMENT SHOULD BE SYMPTOMATIC AND SUPPORTATIVE, REGARDLESS OF THE DOSE RECEIVED. IN ALL CASES, MEDICAL ATTENTION SHOULD BE OBTAINED IMMEDIATELY. 
REACTIVITY:

URANIUM:

CLEAN URANIUM TURNINGS OR CHIPS OXIDIZE READILY IN AIR. IF CONFINED IN A CONTAINER WITHOUT AIR MOVEMENT, THEY CAN IGNITE SPONTANEOUSLY. MOISTURE INCREASES THIS REACTIVITY.

URANIUM TURNINGS STORED IN WATER WILL HYDRIDE AND IGNITE DURING WARM WEATHER INCOMPATIBILITIES:

URANIUM:

CHLORINE: VIOLENT REACTION

AIR: VIOLENT REACTION

FLUORINE: VIOLENT REACTION

NITRIC ACID: REACTS EXPLOSIVELY TR WITH THE FORMATION OF AN EXPLOSIVE SURFACE COATING OR RESIDUE

NITROGEN OXIDE: IGNITES

DINITROGEN TETRAOXIDE: EXPLODES OR FORMS AN EXPLOSIVE SURFACE COATING OR RESIDUE

SELENIUM: REACTS VIOLENTLY OR INCANDESCES

SULFUR: REACTS VIOLENTLY OR INCANDESCES

WATER: VIOLENT REACTION HAZARD

AMMONIA: REACTS VIOLENTLY OR INCANDESCES AT DULL RED HEAT

BROMIUM TRIFLUORIDE: VIOLENT REACTION

TRICHLORO ETHYLENE: VIOLENT REACTION

NITRYL FLUORIDE: VIOLENT REACTION OR GLOWING OR WHITE INCANDESCENCE

CARBON DIOXIDE: AT $750 \mathrm{C}$ INTERACTION IS SO RAPID THAT IGNITION WILL OCCUR WITH THE FINELY DIVIDED METAL, AND AT 500 C THE MASSIVE METAL WILL IGNITE.

CARBON TETRACHLORIDE: USE OF A CARBON TETRACHLORIDE FIRE EXTINGUISHER ON A SMALL URANIUM FIRE LED TO AN EXPLOSION.

CHLORINE: IGNITES AT 150-180 C

BROMINE VAPOR: IGNITES AT 210-240 C

IODINE VAPOR: IGNITES AT $260 \mathrm{C}$

ACIDS: REACTS WITH LIBERATION OF HYDROGEN AND FORMATION OF SALTS OF TETRAVALENT URANIUM.

DECOMPOSITION:

THERMAL DECOMPOSITION MAY RELEASE TOXIC AND/OR HAZARDOUS GASES.

POLYMERIZATION:

NO DATA AVAILABLE.

CONDITIONS TO AVOID

MAY IGNITE ITSELF IF EXPOSED TO AIR. MAY BURN RAPIDLY WITH FLARE-BURNING EFFECT AND RE-IGNITE AFTER FIRE IS EXTINGUISHED.

\section{SPILLS AND LEAKS}

SOIL-RELEASE:

DO NOT HANDLE PACKAGES WITHOUT FULL PROTECTIVE EQUIPMENT.

OCCUPATIONAL-SPILL:

DO NOT TOUCH DAMAGED CONTAINERS OR SPILLED MATERIAL. DAMAGE TO OUTER

CONTAINER MAY NOT AFFECT PRIMARY INNER CONTAINER. FOR SMALL LIQUID SPILLS, 
TAKE UP WITH SAND, EARTH OR OTHER ABSORBENT MATERIAL. FOR LARGE SPILLS, DIKE FAR AHEAD OF SPILL FOR LATER DISPOSAL. KEEP UNNECESSARY PEOPLE AT LEAST 150 FEET UPWIND; GREATER DISTANCES MAY BE NECESSARY IF ADVISED BY QUALIFIED RADIATION AUTHORITY. ISOLATE HAZARD AREA AND DENY ENTRY. ENTER SPILL AREA ONLY TO SAVE LIFE; LIMIT ENTRY TO SHORTEST POSSIBLE TIME. DETAIN UNINJURED PERSONS AND EQUIPMENT EXPOSED TO RADIOACTIVE MATERIAL UNTIL ARRIVAL OR INSTRUCTION OF QUALIFIED RADIATION AUTHORITY. DELAY CLEANUP UNTIL ARRIVAL OR INSTRUCTION OF QUALIFIED RADIATION AUTHORITY.

VENTILATION:

AT A MINIMUM, PROVIDE LOCAL EXHAUST OR PROCESS ENCLOSURE VENTILATION. DEPENDING UPON THE SPECIFIC WORKPLACE ACTIVITY AND THE RADIOACTIVITY OF THE ISOTOPE, A MORE STRINGENT VENTILATION SYSTEM MAY BE NECESSARY TO COMPLY WITH EXPOSURE LIMITS SET FORTH BY LAW (10CFR20.103).

ONE METHOD OF CONTROLLING EXTERNAL RADIATION EXPOSURE IS TO PROVIDE ADEQUATE SHIELDING. THE ABSORBING MATERIAL USED AND THE THICKNESS REQUIRED TO ATTENUATE THE RADIATION TO ACCEPTABLE LEVELS DEPENDS ON THE TYPE OF RADIATION, ITS ENERGY, THE FLUX AND THE DIMENSIONS OF THE SOURCE.

ALPHA PARTICLES - FOR THE ENERGY RANGE OF ALPHA PARTICLES USUALLY ENCOUNTERED, A FRACTION OF A MILLIMETER OF ANY ORDINARY MATERIAL IS SUFFICIENT FOR ABSORBANCE. THIN RUBBER, ACRYLIC, STOUT PAPER, OR CARDBOARD WILL SUFFICE. BETA PARTICLES - BETA PARTICLES ARE MORE PENETRATING THAN ALPHA, AND REQUIRE MORE SHEILDING. MATERIALS COMPOSED MOSTLY OF ELEMENTS OF LOW ATOMIC NUMBER SUCH AS ACRYLIC, ALUMINUM AND THICK RUBBER ARE MOST APPROPRIATE FOR THE ABSORPTION OF BETAA PARTICLES. FOR EXAMPLE, 1/4 INCH OF ACRYLIC WILL ABSORB ALL BETA PARTICLES UP TO 1 MEV. WITH HIGH ENERGY BETA RADIATION FROM LARGE SOURCES, BREMSSTRAHLUNG (X RAY PRODUCTION) CONTRIBUTION MAY BECOME SIGNIFICANT AND IT MAY BE NECESSARY TO PROVIDE ADDITIONAL SHEILDING OF HIGH ATOMIC WEIGHT MATERIAL, SUCH AS LEAD, TO ATTENUATE THE BREMSSTRAHLUNG RADIATION.

GAMMA RAYS- THE MOST SUITABLE MATERIALS FOR SHIELDING GAMMA RADIATION ARE LEAD AND IRON. THE THICKNESS REQUIRED WILL DEPEND ON WHETHER THE SOURCE IS PRODUCING NARROW OR BROAD BEAM RADIATION. PRIMARY AND SECONDARY PROTECTIVE BARRIERS MAY BE REQUIRED TO BLOCK ALL RADIATION.

RESPIRATOR:

OSHA REQUIRED RESPIRATORY PROTECTION FOR URANIUM AND INSOLUBLE COMPOUNDS (AS URANIUM): ONLY NIOSH OR MSHA APPROVED EQUIPMENT SHOULD BE USED.

PARTICULATE CONCENTRATION $2.5 \mathrm{MG} / \mathrm{M3}$ OR LESS

\subsection{MG/M3 OR LESS}

$30 \mathrm{MG} / \mathrm{M} 3$ OR LESS
MINIMUM PROTECTION

-ANY FUME RESPIRATOR OR HIGH EFFICIENCY PARTICULATE FILTER RESPIRATOR APPROVED FOR RADON DAUGHTERS OR RADIONUCLIDES. -ANY SUPPLIED-AIR RESPIRATOR.

- ANY SELF-CONTAINED BREATHING APPARATUS

- A HIGH EFFICIENCY PARTICULATE FILTER RESPRIATOR WITH A FULL FACEPIECE.

-ANY SUPPLIED-AIR RESPIRATOR WITH A FULL FACEPIECE, HELMET OR HOOD.

-ANY SELF-CONTAINED BREATHING APPARATUS WITH A FULL FACEPIECE.

-A POWERED AIR-PURIFYING RESPIRATOR 
GREATER THAN $30 \mathrm{MG} / \mathrm{M3}$ OR ENTRY AND ESCAPE FROM UNKNOWN CONCENTRATIONS

FIRE FIGHTING

WITH A FULL FACEPIECE AND

HIGH-EFFICIENCY PARTICULTE FILTER.

- A TYPE-C SUPPLIED-AIR RESPIRATOR WITH

A FULL FACEPIECE OPERATED IN

PRESSURE-DEMAND OR OTHER POSITIVE MODE

OR WITH A FULL FACEPIECE, HELMET OR

HOOD OPERATED IN CONTINUOUS-FLOW MODE.

-SELF-CONTAINED BREATHING APPARATUS

WITH A FULL FACEPIECE OPERATED IN

PRESSURE-DEMAND OR OTHER POS ITIVE

MSDS \# 2329

PRESSURE MODE.

- A COMBINATION RESPIRATOR WHICH INCLUDE

A TYPE-C SUPPLIED-AIR RESPIRATOR WITH

A FULL FACEPIECE OPERATED IN

PRESSURE-DEMAND OR OTHER POSITIVE

PRESSURE OR CONTINUOUS MODE AND AN

AUXILIARY SELF-CONTAINED BREATHING

APPARATUS OPERATED IN PRESSURE-DEMAND

OR OTHER POSITIVE PRESSURE MODE.

-A HIGH EFFICIENCY PARTICULATE FILTER

RESPIRATOR.

-ANY ESCAPE SELF-CONTAINED BREATHING

APPARATUS.

THIS INFORMATION FROM THE OSHA/NIOSH GUIDELINES, SEPTEMBER, 1978.

HESE RECOMMENDED RESPIRATORS SHOULD PROVIDE PROTECTION FOR THE RESPIRATORY

TRACT AGAINST MOST OF THE RADIOACTIVE PARTICLES ENCOUNTERED IN THE WORK

PLACE. THESE RESPIRATORS WILL NOT OFFER PROTECTION AGAINST BETA AND GAMMA

RADIATION, BUT MAY BLOCK ALPHA PARTICLES. FROM 1OCFR20.103 APPENDIX A.

RESPIRATORY EQUIPMENT MUST BE CERTIFIED BY NIOSH/MSHA.

TYPE ' $C$ ' SUPPLIED-AIR RESPIRATOR WITH A FULL FACEPIECE OPERATED IN

PRESSURE-DEMAND OR OTHER POSITIVE PRESSURE MODE OR WITH A FULL FACEPIECE, HELMET OR HOOD OPERATED IN CONTINOUS-FLOW MOOE.

SELF-CONTAINED BREATHING APPARATUS WITH A FULL FACEPIECE OPERATED IN PRESSURE-DEMAND OR OTHER POSITIVE PRESSURE MODE.

FOR FIREFIGHTING AND OTHER IMMEDIATELY DANGEROUS TO LIFE OR HEALTH CONDITIONS:

SELF-CONTAINED BREATHING APPARATUS WITH FULL FACEPIECE OPERATED IN PRESSURE-DEMAND OR OTHER POSITIVE PRESSURE MODE.

SUPPLIED-AIR RESPIRATOR WITH FULL FACEPIECE AND OPERATED IN PRESSURE-DEMAND OR OTHER POSITIVE PRESSURE MODE IN COMBINATION WITH AN AUXILIARY

SELF-CONTAINED BREATHING APPARATUS OPERATED IN PRESSURE-DEMAND OR OTHER POSITIVE PRESSURE MODE.

CLOTHING:

DIPOSABLE OVERGARMENTS, INCLUDING HEAD COVERINGS AND FOOT COVERING, SHOULD BE WORN BY ANY EMPLOYEE ENGAGED IN HANDL ING ANY RADIACTIVE SUBSTANCE. THESE GARMENTS ARE ALSO RECOMMENDED EVEN IF THE EMPLOYEE IS WORKING WITH A "GLOVE BOX" CONTAINMENT SYSTEM. CERTAIN CLOTHING FIBERS MAY BE USEFUL IN DOSIMETRY 
SO CLOTHING SHOULD BE KEPT.

IN THE EVENT OF AN ACCIDENT, LARGE SCALE RELEASE OR A LARGE SCALE CLEAN-UP FULL PROTECTIVE CLOTHING WILL BE NECESSARY.

\section{GLOVES:}

EMPLOYEE MUST WEAR APPROPRIATE PROTECTIVE GLOVES TO PREVENT CONTACT WITH THIS SUBSTANCE.

USED GLOVES MAY PRESENT A RADIATION HAZARD AND SHOULD BE DISPOSED OF AS RADIOACTIVE WASTE.

EYE PROTECTION:

EMPLOYEE MUST WEAR APPROPRIATE EYE PROTECTION THAT WILL NOT ALLOW THE INTRODUCTION OF PARTICLES INTO THE EYES. CONTACT LENSES SHOULD NOT BE WORN.

CLOTHING, GLOVE, AND EYE PROTECTION EQUIFMENT WILL PROVIDE PROTECTION AGAINST ALPHA PARTICLES, AND SOME PROTECTION AGAINST BETA PARTICLES, DEPENDING ON THICKNESS, BUT WILL NOT SHIELD GAMMA RADIATION.

AUTHORIZED BY- OCCUPATIONAL HEALTH SERVICES, INC. 
PHYSICAL DATA

DESCRIPTION: GRAYISH WHITE, DENSE, SILVERY, RADIOACTIVE SOLID THAT IS STRONGLY ELECTROPOSITIVE. ON VIGOROUS SHAKING THE METALLIC PARTICLES EXHIBIT LUMINISCENCE. IT IS DUCTILE AND MALLEABLE AND IGNITES SPONTANEOUSLY IN AIR.

BOILING POINT: $6904 \mathrm{~F}(3818 \mathrm{C})$

MELTING POINT: $2070 \mathrm{~F}(1132 \mathrm{C})$

SPECIFIC GRAVITY: 19.0 SOLUBILITY IN WATER: INSOLUBLE

OTHER SOLVENTS (SOLVENT - SOLUBILITY):

SOLUBLE IN ACETONE, IN ACIDS AND INSOLUBLE IN ALKALIES

AND ALCOHOL.

OTHER PHYSICAL DATA

NATURAL URANIUM IS $99.27 \%$ U-238, WHICH HAS A HALF-LIFE OF 4.51 E 9 YEARS, AND DECAYS BY ALPHA EMISSION.

\section{FIRE AND EXPLOSION DATA}

FIRE AND EXPLOSION HAZARD

DANGEROUS FIRE HAZARD WHEN EXPOSED TO HEAT OR FLAME.

DANGEROUS EXPLOSION HAZARD WHEN EXPOSED TO HEAT OR FLAME.

FLASH POINT: FLAMMABLE SOLID

FIREFIGHTING MEDIA:

DRY CHEMICAL, CARBON DIOXIDE, HALON, WATER SPRAY OR STANDARD FOAM

(1987 EMERGENCY RESPONSE GUIDEBOOK, DOT P 5800.4).

FOR LARGER FIRES, USE WATER SPRAY OR FOG (FLOODING AMOUNTS)

(1987 EMERGENCY RESPONSE GUIDEBOOK, DOT $P$ 5800.4).

FIREFIGHTING:

MOVE CONTAINERS FROM FIRE AREA IF POSSIBLE. COOL FIRE-EXPOSED CONTAINERS WITH WATER FROM SIDE UNTIL WELL AFTER FIRE IS OUT. STAY AWAY FROM STORAGE TANK ENDS (1987 EMERGENCY RESPONSE GUIDEBOOK, DOT P 5800.4, GUIDE PAGE 65).

DO NOT MOVE DAMAGED CONTAINERS. MOVE UNDAMAGED CONTAINERS OUT OF FIRE ZONE.

FOR MASSIVE FIRE IN STORAGE AREA, USE UNMANNED HOSE HOLDER OR MONITOR NOZZLES.

FIGHT FIRE FROM MAXIMUM DISTANCE'. STAY AWAY FROM STORAGE TANK ENDS (1987

EMERGENCY RESPONSE GUIDEBOOK, DOT P 5800.4, GUIDE PAGE 63).

CONTACT THE LOCAL, STATE, OR DEPARTMENT OF ENERGY RADIOLOGICAL RESPONSE TEAM.

USE SUITABLE AGENT FOR SURROUNDING FIRE. COOL CONTAINERS WITH FLOODING

AMOUNTS OF WATER, APPLY FROM AS FAR A DISTANCE AS POSSIBLE. AVOID BREATHING 
DUSTS OR VAPORS, KEEP UPWIND. KEEP UNNECESSARY PEOPLE OUT OF AREA UNTIL DECLARED SAFE BY RADIOLOGICAL RESPONSE TEAM.

TRANSPORTATION

DEPARTMENT OF TRANSPORTATION HAZARD CLASSIFICATION 49CFR172.101: RADIOACTIVE MATERIAL

DEPARTMENT OF TRANSPORTATION LABELING REQUIREMENTS 49CFR172.101 AND SUBPART E: RADIOACTIVE AND FLAMMABLE SOLID.

DEPARTMENT OF TRANSPORTATION PACKAGING REQUIREMENTS: 49CFR173.418 EXCEPTIONS: NONE

\section{TOXICITY}

URANIUM:

CARCINOGEN STATUS: NONE.

THE TOXICITY OF URANIUM METAL HAS NOT BEEN QUANTIFIED. URANIUM MAY BE A SKIN, EYE, AND MUCOUS MEMBRANE IRRITANT, AS WELL AS A NEPHROTOXIN. URANIUM METAL USUALLY DOES NOT CONSTITUTE AN EXTERNAL RADIATION EXPOSURE HAZARD SINCE IT EMITS MAINLY ALPHA-RADIATION AT A LOW ENERGY LEVEL. IT MAY CONSTITUTE AN INTERNAL RADIATION HAZARD IF IT IS ABSORBED INTO THE BODY, THUS DELIVERING ALPHA EMISSION ONTO TISSUES IN WHICH IT IS STORED.

\section{HEALTH EFFECTS AND FIRST AID}

INHALATION:

URANIUM:

RADIOACTIVE/NEPHROTOXIN. $30 \mathrm{MG/M3}$ IMMEDIATELY DANGEROUS TO LIFE AND HEALTH.

ACUTE EXPOSURE- URANIUM MAY ENTER THE BODY THROUGH INHALATION OF FINE PARTICLES THAT ARE APPROXIMATELY 1 MICRON IN DIAMETER. URANIUM POISONING IS CHARACTERIZED BY GENERALIZED HEALTH IMPAIRMENT. IT MAY CAUSE CHANGES IN THE KIDNEYS, LIVER, LUNGS, AND CARDIOVASCULAR, NERVOUS, AND HEMOPOIETIC SYSTEMS, AND DISORDERS OF PROTEIN AND CARBOHYDRATE METABOLISM. SYMPTOMS MAY INCLUDE OLIGURIA, HEMATURIA, ALBUMINURIA, AND JAUNDICE.

CHRONIC EXPOSURE- WORKERS EXPOSED TO HIGH AVERAGE LEVELS OF URANIUM DUST IN A PLANT AT OAK RIDGE HAVE NOT HAD INCREASED MORTALITY RATES FROM LUNG CANCER, LEUKEMIA, BONE CANCER, OR DISEASES OF THE RESPIRATORY AND GENITOURINARY SYSTEMS. LUNG CANCER IN URANIUM MINERS IS PROBABLY THE RESULT OF INHALATION OF RADON DAUGHTERS FOUND IN THESE MINES. CHRONIC POISONING GIVES CHEST FINDINGS OF PNEUMOCONIOSIS, PRONOUNCED BLOOD CHANGES AND GENERALIZED INJURY. CANCER OF LYMPHATIC AND BLOOD FORMING TISSUES MAY RESULT. SEE THE FOLLOWING SECTIONS REGARDING THE EFFECTS OF INHALATION OF AN ALPHA EMITTER, AND RADIATION SICKNESS.

ALPHA RADIATION:

ACUTE EXPOSURE - ALPHA RADIATION EMITTED FROM RADIONUCLIDES HAS WELL-DEF INED AND CHARACTERISTIC ENERGIES. AS IT IS DOUBLY CHARGED HELIUM IONS, WHICH MOVE RELATIVELY SLOWLY, IT IS DENSELY IONIZING WITH VERY HIGH ENERGY, BUT HAS EXTREMELY LIMITED PENETRATION. THE HIGH ENERGY AND SHORT PATH LENGTH 
BIRTHDAY.

(3) THE EMPLOYER MAINTAINS ADEQUATE PAST AND CURRENT EXPOSURE RECORDS WHICH SHOW THAT THE ADDITION OF SUCH A DOSE WILL NOT EXCEED THESE AMOUNTS.

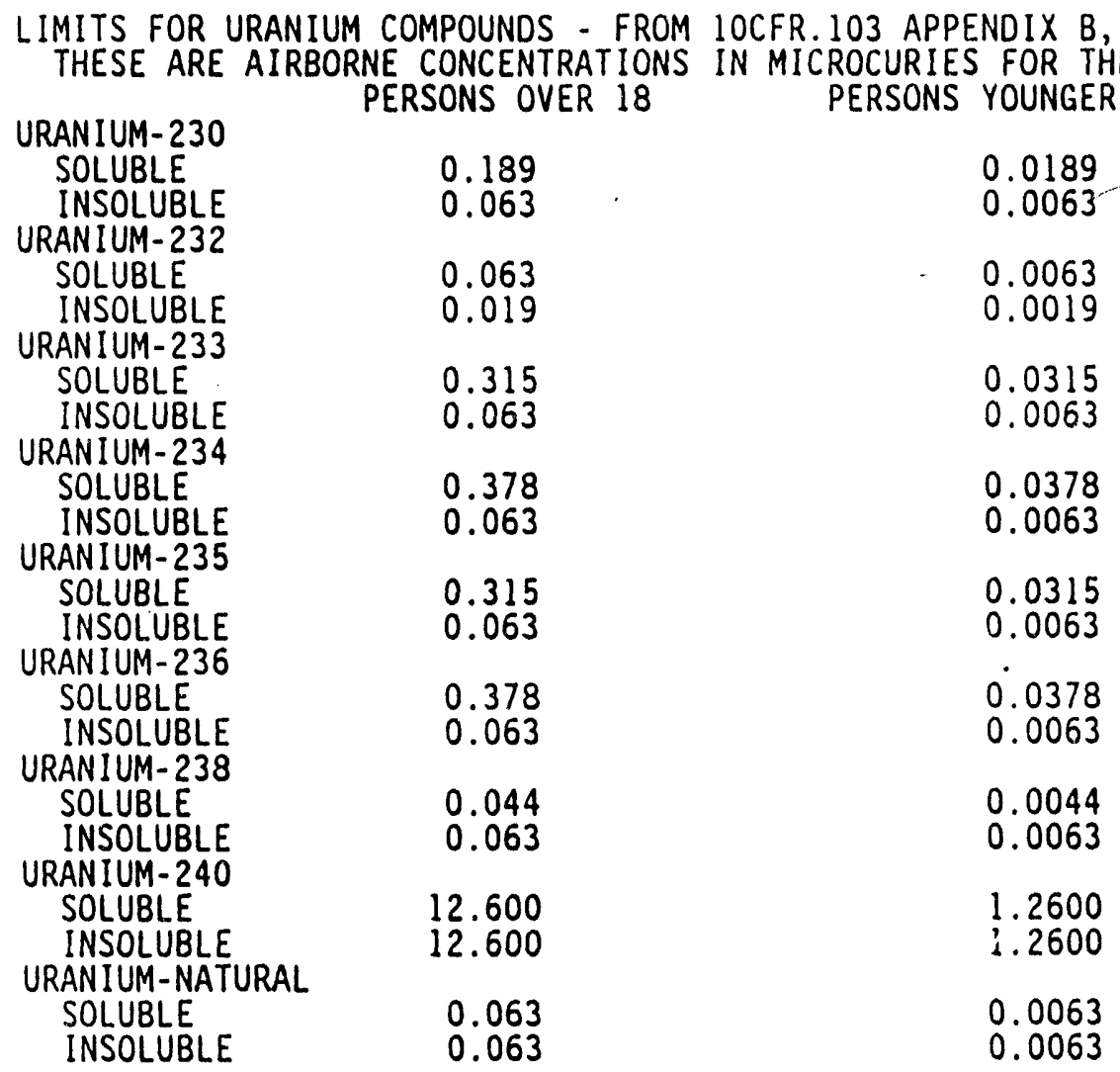

FROM IAEA \# 9 - ANNUAL LIMITS ON INTAKES (ALI) 1982 - IN BECQUERELS (BQ) TO OBTAIN CURIES (CI), DIVIDE BY 3.7 E 10.
A ORAL
B
A INHALATION

MSDS \#2329

URANIUM-230

URANIUM-231

URANIUM-232

URANIUM-233

URANIUM-234

URANIUM- 235

URANIUM-236

URANIUM-237

URANIUM-238

URANIUM-239

URANIUM -240

$\begin{array}{lllllll}1 & E & 5 & & 2 & E & 6 \\ 2 & E & 8 & & 2 & E & 8 \\ 8 & E & 4 & & 2 & E & 6 \\ 4 & E & 5 & & 7 & E & 6 \\ 4 & E & 5 & & 7 & E & 6 \\ 5 & E & 5 & & 7 & E & 6 \\ 5 & E & 5 & & 8 & E & 6 \\ 6 & E & 7 & & 6 & E & 7 \\ 5 & E & 5 & & 8 & E & 6 \\ 2 & E & 9 & & 2 & E & 9 \\ 5 & E & 7 & & 5 & E & 7\end{array}$

$\begin{array}{lll}2 & E & 4 \\ 3 & E & 8 \\ 8 & E & 3 \\ 4 & E & 4 \\ 5 & E & 4 \\ 5 & E & 4 \\ 5 & E & 4 \\ 1 & E & 8 \\ 5 & E & 4 \\ 7 & E & 9 \\ 1 & E & 8\end{array}$

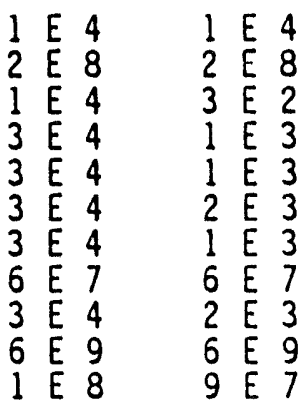

NOTATION SUCH AS "I E 6" MEANS "ONE TIMES TEN TO THE SIXTH".
A. FOR WATER-SOLUBLE INORGANIC COMPOUNDS OF URANIUM (HEXAVALENT URANIUM).
B. FOR RELATIVELY INSOLUBLE COMPOUNOS SUCH AS UF4, UO2, U308, IN WHICH THE URANIUM IS USUALLY TETRAVALENT.
c. UF6, $\mathrm{U} 02 \mathrm{~F} 2, \mathrm{U02}\left(\mathrm{NO}_{3}\right) 2$.
D. U03, UF $4, U C L 4$.
E. U02, U308. 
FFOH HEHF-EHETHE TAOS

-

,

Material Salety Data Sheet

May bo used 10 comply wilh

OSMA's Hezard Communication Slandard.

29 CFR 1910.1200. Standard mugt be

consulted for specific requirements.

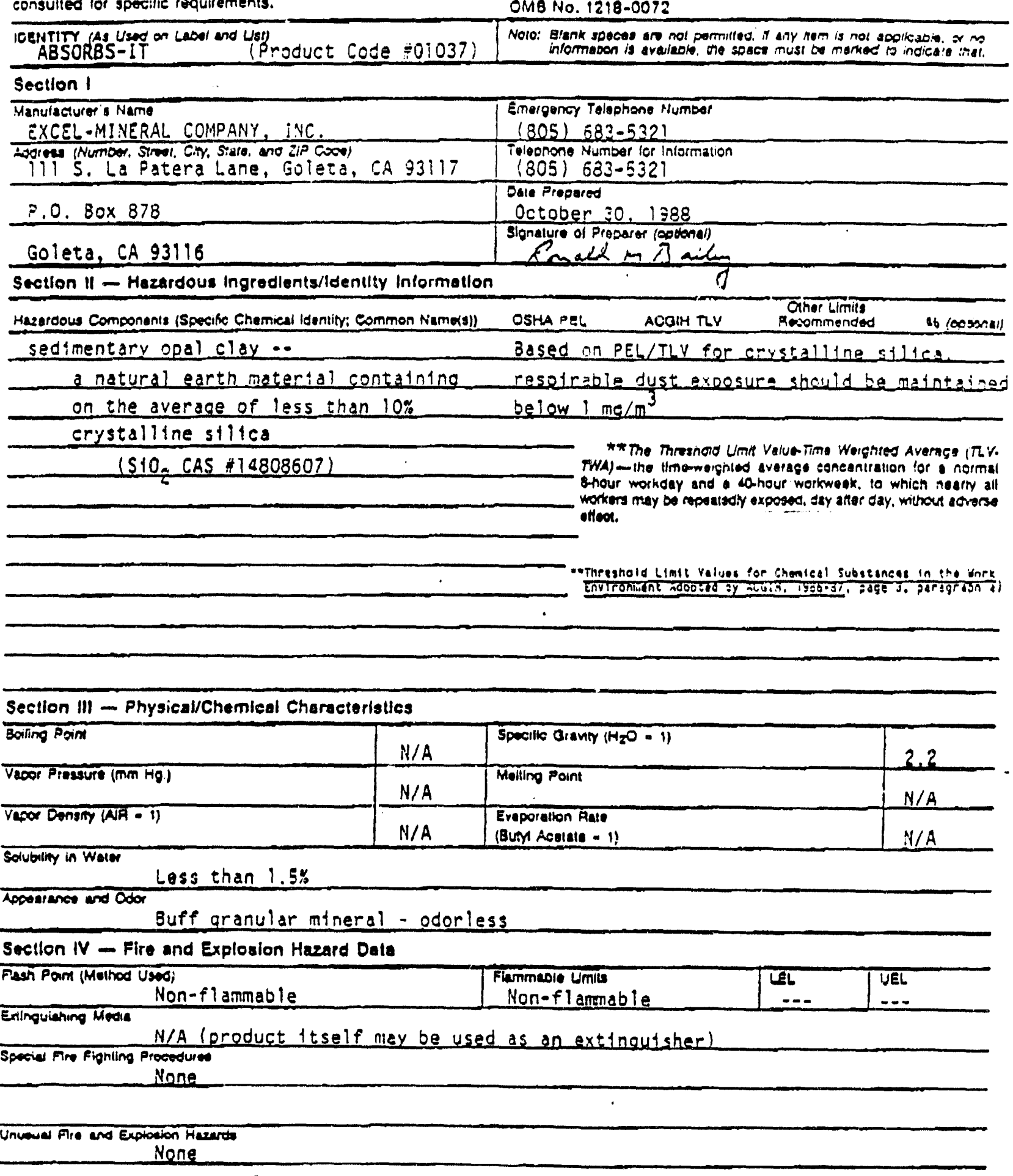

(Aoproduce beally)
U.S. Department of Labor

Oecupational Sareiy ond Health Administration

iNon-Mandatory Form)

Form Approved

OMB NO. 1218-0072 mergency Tolophene Mumber

$805) \quad 682-532$

Dale Propared

October $: 0,1388$

nalure of Preparer (eotional)

J

OSHA PEL ACOIH TH

Ohar Limils

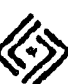

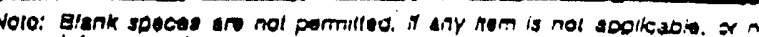

$$
M S O S=\angle O L Z 2
$$

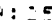 \\ : : : :90 $\div: \div 5$}




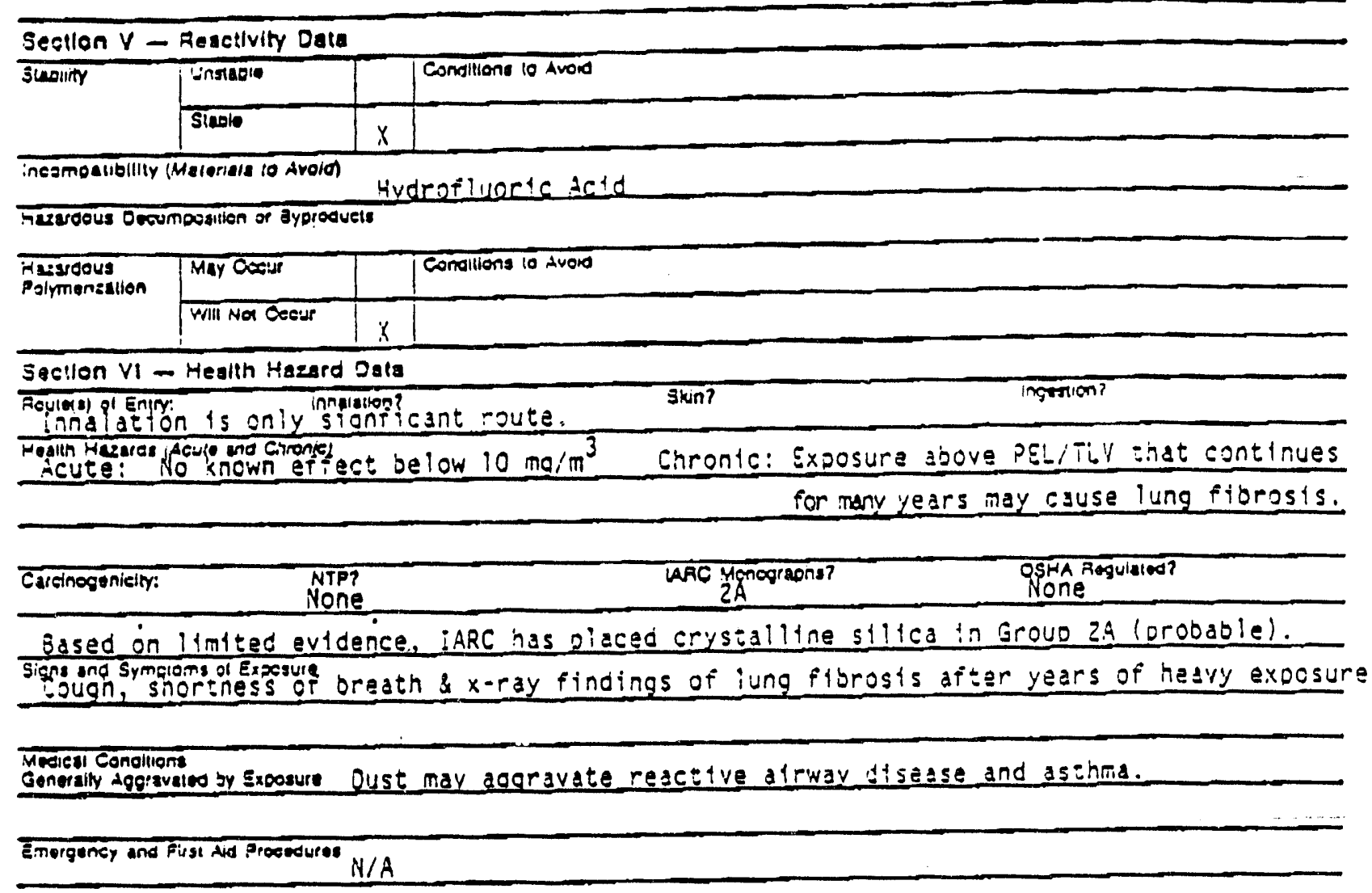

Seclion VII - Precautions for Sare Handling and Uso

Sloos 10 go Texin in Case Meloriel Is Foloesed of Spllios sweeg yo or vacuum.

Use zooroved dust resolrator if airborne concentration exceeds the PSL/TLV.

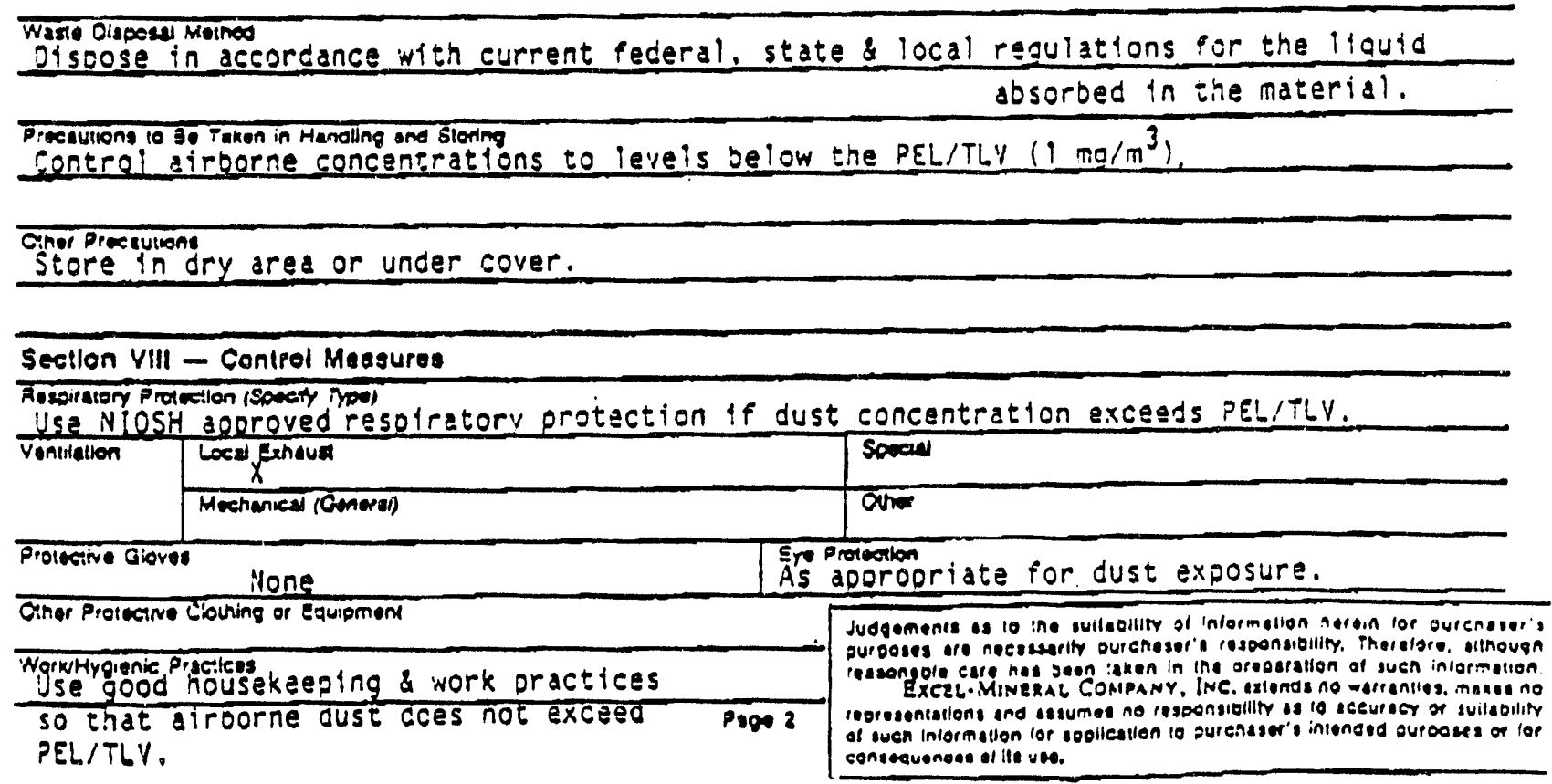


OCCUPATIONAI HEALTH SERVICES, INC. I1 WEST 42ND STREET, 12TH FLOOR NEW YORK, NEW YORK 10036 $1-800-445$-MSDS $(1-800-445-6737)$ OR $1-212-789-3535$ ...............

SUBSTANCE : TETRACHLOROETHYLENE
FOR EMERGENCY SOURCE INFORMATION CONTACT: $1-615-366-2000$

\section{SUBSTANCE IDENTIFICATION}

MSDS \#1418

TRADE NAMES/SYNONYMS :

ETHENE，TETRACHLORO-; ETHYLENE，TETRACHLORO-; ANKILOSTIN; DIDAKEN; NEMA; ETHYLENE TETRACHLORIDE; PERCHLOROETHYLENE; PERC; PERCHLOROETHENE; PERCLENE; 1,1,2,2-TETRACHLOROETHYLENE; TETRACAP; TETRACHLOROETHENE; PCE; RCRA U210; NCI-CO4580; ENT 1,860; STCC 4940355; UN 1897; C2CL4; OHS22900

CHEMICAL FAMILY:

HALOGEN COMPOUND, ALIPHATIC

MOLECULAR FORMULA: CL2-C-C-CL2

MOLECULAR WEIGHT: 165.83

CERCLA RATINGS (SCALE 0-3): HEALTH=3 FIRE=0 REACTIVITY=0 PERSISTENCE $=2$ NFPA RATINGS (SCALE 0-4): HEALTH $=2$ FIRE $=0$ REACTIVITY $=0$ COMPONENTS AND CONTAMINANTS

COMPONENT: TETRACHLOROETHYLENE

PERCENT: 100.0

$$
\text { CAS\# } 127-18-4
$$

OTHER CONTAMINANTS: NONE

EXPOSURE LIMITS:

TETRACHLOROETHYLENE (PERCHLOROETHYLENE) :

25 PPM ( 170 MG/M3) OSHA TWA

50 PPM (339 MG/M3) ACGIH TWA; 200 PPM (1357 MG/M3) ACGIH STEL

LOWEST FEASIBLE LIMIT NIOSH RECOMMENDED EXPOSURE CRITERIA

50 PPM ( 339 MG/M3) DFG MAK TWA;

100 PPM ( $678 \mathrm{MG} / \mathrm{M} 3)$ DFG MAK 30 MINUTE PEAK, AVERAGE VALUE, 4 TIMES/SHIFT

MEASUREMENT METHOD: CHARCOAL TUBE; CARBON DISULFIDE; GAS CHROMATOGRAPHY WITH FLAME IONIZATIN DETECTION; (NIOSH VOL. III \# 1003, HALOGENATED HYDROCARBONS).

100 POUND CERCLA SECTION 103 REPORTABLE QUANTITY

SUBJECT TO SARA SECTION 313 ANNUAL TOXIC CHEMICAL RELEASE REPORTING SUBJECT TO CALIFORNIA PROPOSITION 65 CANCER AND/OR REPRODUCTIVE. TOXICITY WARNING AND RELEASE REQUIREMENTS- (APRIL 1, 1988) 
DESCRIPTION: CLEAR, COLORLESS, VOLATILE LIQUID WITH A MILD ETHER-LIKE ODOR. BOILING POINT: $250 \mathrm{~F}(121 \mathrm{C})$ MELTING POINT: $-2 \mathrm{~F}(-19 \mathrm{C})$ SPECIFIC GRAVITY: 1.6227 VOLATILITY: 100\% VAPOR PRESSURE: 14 MMHG@ $20:$ EVAPORATION RATE: (BUTYL ACETATE=1) 2.8 SOLUBILITY IN WATER: $0.015 \%$ ODOR THRESHOLD: 50 PPM VAPOR DENSITY: 5.83 SOLVENT SOLUBILITY: SOLUBLE IN ALCOHOL, ETHER, BENZENE, CHLOROFORM, OILS, HEXANE.

FIRE AND EXPLOSION DATA MSDS $\# 1418 \ldots . .$.

FIRE AND EXPLOSION HAZARD:

NEGLIGIBLE FIRE HAZARD WHEN EXPOSED TO HEAT OR FLAME.

FIREFIGHTING MEDIA:

DRY CHEMICAL OR CARBON DIOXIDE

(1990 EMERGENCY RESPONSE GUIDEBOOK, DOT P 5800.5).

FOR LARGER FIRES, USE WATER SPRAY, FOG OR REGULAR FOAM (1990 EMERGENCY RESPONSE GUIDEBOOK, DOT P 5800.5).

FIREFIGHTING :

APPLY COOLING WATER TO SIDES OF CONTAINERS THAT ARE EXPOSED TO FLAMES UNTIL WELL AFTER FIRE IS OUT. STAY AWAY FROM ENDS OF TANKS. ISOLATE FOR 1/2 MILE IN ALL DIRECTIONS IF TANK, RAIL CAR OR TANK TRUCK IS INVOLVED IN FIRE (1990 EMERGENCY RESPONSE GUIDEBOOK, DOT P 5800.5, GUIDE PAGE 74).

EXTINGUISH USING AGENT(S) SUITABLE FOR TYPE OF SURROUNDING FIRE. AVOID CONTAMINATION OF WATER SOURCES AND SEWERS. BUILD DIKES TO CONTAIN FLOW. AVOID BREATHING VAPORS; KEEP UPWIND.

TRANSPORTATION DATA

DEPARTMENT OF TRANSPORTATION HAZARD CLASSIFICATION 49 CFR 172.101: ORM-A

DEPARTMENT OF TRANSPORTATION LABELING REQUIREMENTS 49 CFR 172.101 AND SUBPART E:

NONE

DEPARTMENT OF TRANSPORTATION PACKAGING REQUIREMENTS: 49 CFR 173.605 EXCEPTIONS : 49 CFR 173.505 


\section{MSTS $\# 14+8 \ldots \ldots$}

TETRACHLOROETHYLENE (PERCHLOROETHYLENE) :

IRRITATION DATA: 810 MG/24 HOURS SKIN-RABBIT SEVERE; 500 MG $/ 24$ HOURS SKIN-RABBIT MILD; 162 MG EYE-RABBIT MILD; 500 MG/24 HOURS EYE-RABBIT MILD.

TOXICITY DATA: 96 PPM/7 HOURS INHALATION-HUMAN TCLO; 280 PPM/ 2 HOURS INHALATION-MAN TCLO; 600 PPM/10 MINUTES INHALATION-MAN TCLO; 34,200 MG/M3/3 HCURS INHALATION-RAT LC50; 5200 PPM/4 HOURS INHALATION-MOUSE LC5O; $>10,000 \mathrm{MG} / \mathrm{KG}$ SKIN-RABBIT LD50 (DOW MSDS); $2629 \mathrm{MG} / \mathrm{KG}$ ORAL-RAT LD50; 8100 MG/KG ORAL-MOUSE LD50; 5000 MG/KG ORAL-RABBIT LDLO; 4000 MG/KG ORAL-CAT LDLO; $4000 \mathrm{MG} / \mathrm{KG}$ ORAL-DOG LDLO; $2200 \mathrm{MG/KG} \mathrm{SUBCUTANEOUS-RABBIT} \mathrm{LDLO;}$ $65 \mathrm{GM} / \mathrm{KG}$ SUBCUTANEOUS-MOUSE LD50; $85 \mathrm{MG} / \mathrm{KG}$ INTRAVENOUS-DOG LDLO; $4678 \mathrm{MG} / \mathrm{KG}$ INTRAPERITONEAL-RAT LD50; 2100 MG/KG INTRAPERITONEAL-DOG LD50; MUTAGENIC DATA (RTECS); RERRODUCTIVE EFEECTS DATA (RTECS); TUMORIGENIC DATA (RTECS).

CARCINOGEN STATUS: ANTICIPATED HUMAN CARCINOGEN (NTP); HUMAN INADEQUATE EVIDENCE, ANIMAL SUFFICIENT EVIDENCE (IARC GROUP-2B). IN MICE, ORAL ADMINISTRATION AND INHALATION PRODUCED HEPATOCELLULAR CARCINOMAS IN BOTH SEXES. EXPOSURE OF RATS BY INHALATION PRODUCED AN INCREASED INCIDENCE OF MONONUCLEAR CELL LEUKEMIA IN BOTH SEXES.

LOCAL EFFECTS: IRRITANT- INHALATION, SKIN, EYES.

ACUTE TOXICITY LEVEL: MODERATELY TOXIC BY' INHALATION, INGESTION; SLIGHTLY TOXIC BY SKIN ABSORPTION.

TARGET EFFECTS: CENTRAL NERVOUS SYSTEM DEPRESSANT. POISONING MAY ALSO AFFECT THE LIVER AND KIDNEYS.

AT INCREASED RISK FROM EXPOSURE: PERSONS WITH PRE-EXISTING SKIN, EYE, LIVER, KIDNEY, CARDIOVASCULAR OR NEUROLOGICAL DISORDERS.

ADDITIONÁL DATA: ALCOHOL MAY ENHANCE THE TOXIC EFEECTS. STIMULANTS SUCH AS ERINEPHRINE MAY INDUCE VENTRICULAR FIBRILLATION. MAY BE EXCRETED IN BREAST MILK. ONE STUDY SHOWS AN INCREASED RISK OF LEUKEMIA FOR CHILDREN WHOSE FATHERS HAD OCCUPATIONAI EXPOSURE TO CHLORINATED SOLVENTS AFTER THE BIRTH OF THE CHILD.

HEALTH EFFECTS AND FIRST AID

INHALATION :

TETRACHLOROETHYLENE (PERCHLOROETHYLENE) :

IRRITANT/NARCOTIC/CARCINOGEN.

ACUTE EXPOSURE - VAPOR CONCENTRATIONS FROM 100-400 PPM MAY CAUSE IRRITATION OF THE NOSE, THROAT AND MUCOUS MEMBRANES, FLUSHED FACE AND NECK, SINUS CONGESTION, NASAI DISCHARGE, HEADACHE, DIZZINESS, LIGHTHEADEDNESS, DROWSINESS, THICK TONGUE, TIGHTNESS AROUND THE MOUTH, SLURRED SPEECH, CONFUSION, INCOORDINATION, NAUSEA, AND REVERSIBLE LIVER AND KIDNEY CHANGES; $400-600$ PPM MAY CAUSE SALIVATION, METALIIC TASTE, PERSPIRATION OF THE HANDS, AND LOSS OF INHIBITIONS; 1000-2000 PPM MAY CAUSE MARKED UPPER RESPIRATORY IRRITATION, ANESTHESIA OF THE LIPS AND NOSE, CONGESTED EUSTACHIAN TUBES, ACHING FACIAL MUSCLES, INEBRIATION, EXHILARÁTION, MENTAL SLUGGISHNESS, LASSITUDE, GAGGING, FAINTNESS, TINIITUS, DYSPNEA UPON EXERTION, NARCOSIS, AND' LIVER AND KIDNEY DAMAGE. OTHER REPORTED SYMPTOMS INCLUDE WEAKNESS, ATAXIA, COUGHING, CHEST PAINS, RARID, WEAK PULSE, BLURRED VISION, IRRITABILITY, ANOREXIA, VOMITING, HALLUCINATIONS, DISTORTED PERCEPTIONS, ACIDOSIS, LATENT JAUNDICE AND ABNORMAL LIVER 
$\mathrm{DOE} / \mathrm{RL}-90-04$

FUNCTION TESTS, ALBUMINURIA, HEMATURIAMASORZ \#/4/8 PAGE 4 BEATS. MASSIVE EXPOSURES MAY CAUSE PULMONARY EDEMA, UNCONSCIOUSNESS, COMA AND DEATH FROM ANESTHESIA OR RESPIRATORY ARREST. IN ONE FATAL CASE, PATHOLOGIC FINDINGS INCLUDED CENTRAL FATTY NECROSIS AND FATTY INFILTRATION OF THE IIVER AND MODERATE CLOUDY SWELIING OF THE RENAL TUBUIAAR EPITHELIUM. EPINEPHRINE - INDUCED CARDIAC ARRHYTHMIAS HAVE OCCURRED WITH SOME HYDROCARBONS, BUT TESTING OF TETRACHLOROETHYLENE IN DOGS HAS BEEN NEGATIVE.

CHRONIC EXPOSURE - WORKERS EXPOSED TO 1-40 PPM OVER 7.5 YEARS SHOWED ALTERED ELECTRODIAGNOSTIC AND NEUROLOGICAL RATING SCORES; 4 OF 16 EXPOSED TO 60-450 PPM FOR 2-20 YEARS HAD ABNORMAL EEG'S. REPEATED EXPOSURE MAY ALSO CAUSE RESPIRATORY TRACT IRRITATION, CENTRAL NERVOUS SYSTEM DEPRESSION WITHOUT NARCOSIS, CONFUSION, HEADACHE, FATIGUE, DIZZINESS, INEBRIATION, INSOMNIA, NAUSEA, ANOREXIA, ABDOMINAL PAIN, CONSTIPATION, BLURRED VISICN, MULTIPLE PREMATURE VENTRICULAR BEATS, AND PERIPHERAL NEUROPATHY WITH NUMBNESS IN THE FINGERS, TREMBLING, NEURITIS, AND MEMORY DEFECTS. HEPATIC DAMAGE MAY OCCUR AND BE PERSISTENT. EXPOSURE TO LEVELS AROUND 250 PPM FOR 4 MONTHS HAS BEEN REPORTED TO HAVE CAUSED HEMOPTYSIS, COUGHING, SWEATING ATTACKS, JAUNDICE, OLIGURIA, HEMATEMESIS,

CARDIOVASCULAR FAILURE AND DEATH. OCCASIONAL IDIOSYNCRATIC REACTIONS HAVE BEEN REPORTED INCLUDING PULMONARY EDEMA, BRONCHIAL ASTHMA, DEPENDENCY, AND HYPERSENSITIVITY. CHRONIC STUDIES IN RATS HAVE PRODUCED LIVER AND KIDNEY DAMAGE. IN STUDIES OF WOMEN WORKING IN THE DRY CLEANING INDUSTRY, ONE STUDY SHOWED HIGHER INCIDEIJCES OF MENSTRUAL DISORDERS, INDICATING AN EFFECT ON THE HORMONE SYSTEM. ANOTHER STUDY REVEALED AN ASSOCIATION BETWEEN EXPOSURE DURING EARLY PREGNANCY AND A SIGNIFICANTLY INCREASED INCIDENCE OF SPONTANEOUS ABORTIONS. REPRODUCTIVE EFFECTS HAVE ALSO BEEN REPORTED IN ANIMALS. INHALATION STUDIES INDICATE AN INCREASED INCIDENCE OF LIVER CARCINOMAS IN MICE AND MONONUCLEAR CELL LEUKEMIA IN RATS.

FIRST AID- REMOVE FROM EXPOSURE AREA TO FRESH AIR IMMEDIATELY. IF BREATHING HAS STOPPED, GIVE ARTIFICIAL RESPIRATION. MAINTAIN AIRWAY AND BLOOD

PRESSURE AND ADMINISTER OXYGEN IF AVAILABLE. KEEP AFFECTED PERSON WARM AND AT REST. TREAT SYMPTOMATICALLY AND SUPPORTIVELY. ADMINISTRATION OF OXYGEN SHOULD BE PERFORMED BY QUALIFIED PERSONNEL. GET MEDICAL ATTENTION IMMED IATELY.

SKIN CONTACT:

TETRACHLOROETHYLENE (PERCHLOROETHYLENE):

IRRITANT.

ACUTE EXPOSURE- BRIEF IMMERSION OF THE HANDS IN THE LIQUID USUALLY CAUSES ONLY MILD IRRITATION. HOWEVER, THE LIQUID ON THE SKIN FOR 40 MINUTES RESULTED IN A PROGRESSIVELY SEVERE BURNING SENSATION, BEGINNING WITHIN 5-10 MINUTES, AND MARKED ERYTHEMA, WHICH SUBSIDED AFTER 1-2 HOURS . SEVERE EXPOSURES MAY RESULT IN VESICULATION AND POSSIBLY BURNS. ABSORPTION MAY OCCUR BUT IS PROBABLY NUT A SIGNIFICANT ROUTE OE EXPOSURE. CHRONIC EXPOSURE - REPEATED OR PROLONGED SKIN CONTACT MAY PRODUCE DERMATITIS WITH DRY, SCALY, FISSURED SKIN.

FIRST AID- REMOVE CONTAMINATED CLOTHING AND SHOES IMMEDIATELY. WASH AFFECTED AREA WITH SOAP OR MILD DETERGENT AND LARGE AMOUNTS OF WATER UNTII NO EVIDENCE OF CHEMICAL REMAINS (APPROXIMATELY 15-20 MINUTES). GET MEDICAL 
ATTENTION IMMEDIATELY.

EYE CONTACT:

TETRACHLOROETYLENE (PERCHLOROETHYLENE) :

MSDS \#1418

IRRITANT .

ACUTE EXPOSURE- VAPOR CONCENTRATIONS FROM 100-200 MAY CAUSE MILD IRRITATION. HIGHER LEVELS OR DIRECT CONTACT MAY CAUSE PAIN, LACRIMATION, AND BURNING, BUT SERIOUS INUURY. IS UNLIKELY. AT 1500 PMM, THE IRRITATION IS ALMOST INTOLERABLE. TWO STUDIES OF DIRECT APPLICATION TO RABBIT EYES RESULTED IN CONUUNCTIVITIS AND EFFECTS ON THE CORNEAL ERITHELIUM; RECOVERY WAS COMPLETE IN 2 DAYS TO 2 WEEKS.

CHRONIC EXPOSURE- REPEATED OR PROLONGED EXPOSURE MAY CAUSE CONUUNCTIVITIS. ONE STUDY HAS REPORTED AN INCREASED INCIDENCE OF LACRIMAL DUCT DISEASE IN EXPOSED WORKERS.

FIRST AID- WASH EYES IMMEDIATELY WITH LARGE AMOUNTS OF WATER OR NORMAL SALINE, OCCASIONALLY LIFTING UPPER AND LOWER LIDS, UNTIL NO EVIDENCE OF CHEMICAL REMAINS (APRROXIMATELY 15-20 MINUTES). GET MEDICAL ATTENTION IMMEDIATELY.

INGESTION :

TETRACHLOROETHYLENE (PERCHLOROETHYLENE):

NARCOTIC/CARCINOGEN.

ACUTE EXPOSURE - MAY CAUSE SEVERE GASTROINTESTINAL IRRITATION WITH NAUSEA, VOMITING, ABDOMINAI CRAMPS AND DIARRHEA, POSSIBLY WITH BLOODY STOOLS. NARCOTIC EFFECTS MAY INCLUDE HEADACHE, DIZZINESS, EXHILARATION, INEBRIATION AND OTHER EFFECTS AS IN ACUTE INHALATION. A DOSE OF 500 MG/KG HAS BEEN INGESTED AND SURVIVED. DOGS GIVEN LETHAL DOSES EXHIBITED CARDIAC AND RESPIRATORY DEPRESSION; AUTOPSY REVEALED FATTY INEILTRATION OF THE HEART AND LIVER AND MARKED INFLAMMATION AND SHRIVELING OF THE SMALL INTESTINE. CHRONIC EXPOSURE- LONGTERM INGESTION OF $50 \mathrm{MG} / \mathrm{KG}$ PRODUCED LIVER AND KIDNEY DAMAGE IN MICE. CHRONIC INGESTION HAS PRODUCED HEPATOCELLULAR CARCINOMAS IN MICE.

EIRST AID- IF THE PERSON IS CONSCIOUS AND NOT CONVULSING, INDUCE EMESIS BY GIVING SYRUP OF IPECAC (KEEPING THE HEAD BELOW THE HIPS TO PREVENT ASEIRATION), FOLLOWED BY WATER. REPEAT IN 20 MINUTES IF NOT EFFECTIVE INITIAILY. IN PATIENTS WITH DEPRESSED RESPIRATION OR IF EMESIS IS NOT PRODUCED, PERFORM GASTRIC LAVAGE CAUTIOUSLY (DREISBACH, HANDBOOK OF POISONING, 12TH ED.). TREAT SYMPTOMATICALLY AND SUPPORTIVELY. GASTRIC LAVAGE SHOULD BE PERFORMED BY QUALIFIED MEDICAL PERSONNEL. GET MEDICAL ATTENTION IMMEDIATELY.

ANTIDOTE :

NO SPECIEIC ANTIDOTE. TREAT SYMPTOMATICALLY AND SUPPORTIVELY.

\section{REACTIVITY}

REACTIVITY :

STABLE UNDER NORMAL TEMPERATURES AND PRESSURES.

INCOMPATIBILITIES :

TETRACHLOROETYLENE (PERCHLOROETHYLENE) : ALUMINUM: MAY FORM EXPLOSIVE MIXTURE. 
BARIUM: FORMS A DETONABLE MIXTURE.

BASES: MAY FORM EXPLOSIVE MIXTURE.

BERYILIUM: POSSIBLE EXPLOSIVE MIXTURE.

DINITROGEN TETRAOXIDE: EXPLOSIVE WHEN SUBJECTED TO EXTREME SHOCK.

METALS (LIGHT) : VIOLENT REACTION.

OXYGEN (LIQUID): INCOMPATIBLE.

PLASTICS, RUBBER, AND COATINGS: MAY BE ATTACKED. POTASSIUM HYDROXIDE: MAY FORM EXPLOSIVE MIXTURE.

SODIUM HYDROXIDE: MAY FORM EXPLOSIVE MIXTURE.

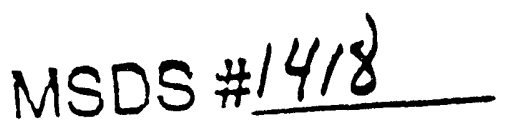

DECOMPOSITION :

THERMAL DECOMPOSITION PRODUCTS MAY INCLUDE HIGHLY TOXIC FUMES OF PHOSGENE, TOXIC AND CORROSIVE FUMES OF CHLORIDES, AND OXIDES OF CARBON.

POLYMERIZATION :

HAZARDOUS POLYMERIZATION HAS NOT BEEN REPORTED TO OCCUR UNDER NORMAL TEMPERATURES AND PRESSURES.

\section{STORAGE AND DISPOSAL}

OBSERVE ALL FEDERAL, STATE AND LOCAL REGULATIONS WHEN STORING OR DISPOSING OF THIS SUBSTANCE. FOR ASSISTANCE, CONTACT THE DISTRICT DIRECTOR OF THE ENVIRONMENTAL PROTECTION AGENCY.

\section{* *STORAGE**}

STORE IN A COOL, DRY, WELL-VENTILATED LOCATION, AWAY FROM ANY AREA WHERE THE FIRE HAZARD MAY' BE ACUTE (NEPA 49, HAZARDOUS CHEMICALS DATA, 1975).

STORE AWAY FROM INCOMPATIBLE SUBSTANCES.

\section{**DISPOSAL* *}

DISPOSAL MUST BE IN ACCORDANCE WITH STANDARDS APPLICABLE TO GENERATORS OF HAZARDOUS WASTE, 4OCER 262. EPA HAZARDOUS WASTE NUMBER U2 10.

TETRACHLOROETHYLENE - REGULATORY LEVEL: $0.7 \mathrm{MG} / \mathrm{L}$

MATERIALS WHICH CONTAIN THE ABOVE SUBSTANCE AT OR ABOVE THE REGULATORY

LEVEL MEET THE EPA CHARACTERISTIC OF TOXICITY, AND MUST BE DISPOSED OF IN

ACCORDANCE WITH 40 CFR PART 262. EPA HAZARDOUS WASTE NUMBER D039.

\section{CONDITIONS TO AVOID}

MAY BURN BUT DOES NOT IGNITE READILY. CONTAINER MAY EXPLODE IN HEAT OF FIRE.

\section{SPILL AND LEAK PROCEDURES}


DOE/RL-90-04

PAGE 7

DIG A HOLDING AREA SUCH AS A PIT, POND OR LAGOON TO CONTAIN SPILL AND DIKE SUTRFACE FLOW USING BARRIER OF SOIL, SANDBAGS, FOAMED POLYURETHANE OR FOAMED CONCRETE. ABSORB LIQUID MASS WITH FLY ASH OR CEMENT POWDER.

AIR SPILL:

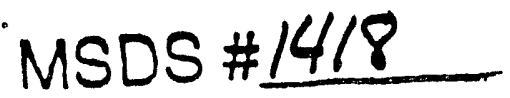

APPLY WATER SPRAY TO KNOCK DOWN AND REDUCE VAPORS. KNOCK-DOWN WATER IS

CORROSIVE AND TOXIC AND SHOULD BE DIKED FOR CONTAINMENT AND LATER DISPOSAL.

WATER SPILL:

IF DISSOLVED, AT A CONCENTRATION OF 10 PPM OR GREATER, APPLY ACTIVATED CARBCN

AT TEN TIMES THE AMOUNT THAT HAS BEEN SPILLED.

USE SUCTION HOSES TO REMOVE TRAPPED SPILL MATERIAL.

THE CALIFORNIA SAFE DRINKING WATER AND TOXIC ENFORCEMENT ACT OF 1986 (PROPOSITION 65) PROHIBITS CONTAMINATING ANY KNOWN SOURCE OF DRTNKING WATER WITH SUBSTANCES KNOWN TO CAUSE CANCER AND/OR REPRODUCTIVE TOXICITY.

OCCUPATIONAL SPILL:

SHUT OFF IGNITION SOURCES. STOR LEAK IF YOU CAN DO IT WITHOUT RISK. FOR SMALL LIQUID SPILIS, TAKE UP WITH SAND, EARTH OR OTHER ABSORBENT MATERIAL. FOR LARGER SPILLS, DIKE FAR AHEAD OF SPILI EOR LATER DISPOSAL. NO SMOKING, FLAMES OR FLARES IN HAZARD AREA! KEEP UNNECESSARY PEOPLE AWAY.

REPORTABLE QUANTITY (RQ): 1 POUND

THE SUPERFUND AMENDMENTS AND REAUTHORIZATION ACT (SARA) SECTION 304 REQUIRES TEAT A RELEASE EQUAL TO OR GREATER THAN THE REPORTABLE QUANTITY FOR THIS SUBSTANCE BE IMMEDIATELY REPORTED TO THE LOCAL EMERGENCY RLANNING COMMITTEE AND THE STATE EMERGENCY RESPONSE COMMISSION (40 CER 355.40). IF THE RELEASE OF THIS SUBSTANCE IS REPORTABLE UNDER CERCLA SECTION 103, THE NATIONAL RESPONSE CENTER MUST BE NOTIFIED IMMEDIATELY AT (800) 424-8802 OR (202) 426-2675 IN THE METROPOLITAN WASHINGTON, D.C. AREA (40 CFR 302.6).

PROTECTIVE EQUIPMENT

VENTIIATION :

EROCESS ENCLOSURE RECOMMENDED TO MEET PUBLISHED EXPOSURE LIMITS.

RESPIRATOR :

THE FOLLOWING RESPIRATORS AND MAXIMUM USE CONCENTRATIONS ARE RECOMMENDATIONS BY THE U.S. DEPARTMENT OF HEALTH AND HUMAN SERVICES, NIOSH POCKET GUIDE TO CHEMICAL HAZARDS; NIOSH CRITERIA DOCUMENTS OR BY THE U.S. DERARTMENT UE LABOR, 29 CFR 1910 SUBPART Z.

THE SPECIFIC RESPIRATOR SELECTED MUST BE BASED ON CONTAMINATION LEVELS FOUND IN THE WORK PLACE, MUST NOT EXCEED THE WORKING LIMITS OF THE RESPIRATOR AND BE JOINTLY APPROVED BY THE NATIONAL INSTITUTE FOR OCCUPATIONAL SAFETY AND HEALTH AND THE MINE SAFETY AND HEALTH ADMINISTRATION (NIOSH-MSHA).

TETRACHLOROETHYLENE :

AT ANY DETECTABLE CONCENTRATION:

SELF-CONTAINED BREATHING APPARATUS WITH FULL FACEPIECE OPERATED IN 


\section{MSDS $14 / 8$}

PRESSURE-DEMAND OR OTHER POSITIVE PRESSURE MODE.

SUPPLIED-AIR RESPIRATOR WITH FULL FACEPIECE OPERATED IN

PRESSURE-DEMAND OR OTHER POSITIVE PRESSURE MODE IN COMBINATION

WITH AN AUXILIARY SELF-CONTAINED BREATHING APPARATUS OPERATED

IN PRESSURE-DEMAND OR OTHER POSITIVE PRESSURE MODE.

ESCAPE- AIR-PURIFYING FULL FACEPIECE RESPIRATOR (GAS MASK), WITH A CHIN-STYLE, FRONT - OR BACK - MOUNTED ORGANIC VAPOR CANISTER.

ANY APPROPRIATE ESCAPE-TYPE, SELF-CONTAINED BREATHING APPARATUS.

FOR FIREFIGHTING AND OTHER IMMEDIATELY DANGEROUS TO LIFE OR HEALTH CONDITIONS:

ANY SELF-CONTAINED BREATHING APPARATUS THAT HAS A EULL FACEPIECE AND IS OPERATED IN A PRESSURE-DEMAND OR OTHER POSITIVE-PRESSURE MODE.

ANY SUPPLIED-AIR RESPIRATOR THAT HAS A FULL FACEPIECE AND IS OPERATED IN A PRESSURE-DEMAND OR OTHER POSITIVE-PRESSURE MODE IN COMBINATION WITH AN AUXILIARY SELF-CONTAINED BREATHING APPARATUS OPERATED IN PRESSURE-DEMAND OR OTHER POSITIVE-PRESSURE MODE.

CLOTHING :

EMPLOYEE MUST WEAR APPROPRIATE PROTECTIVE (IMPERVIOUS) CLOTHING AND EQUIPMENT TO PREVENT REPEATED OR PROLONGED SKIN CONTACT WITH THIS SUBSTANCE.

GLOVES :

EMPLOYEE MUST WEAR APPROPRIATE PROTECTIVE GLOVES TO PREVENT CONTACT WITH THIS SUBSTANCE.

EYE PROTECTION:

EMPLOYEE MUST WEAR SPLASH-PROOF OR DUST-RESISTANT SAFETY GOGGLES TO PREVENT EYE CONTACT WITH THIS SUBSTANCE.

EMERGENCY EYE WASH: WHERE THERE IS ANY POSSIBILITY THAT AN EMPLOYEE'S EYES MAY BE EXPOSED TO THIS SUBSTANCE, THE EMPLOYER SHOULD PROVIDE AN EYE WASH FOUNTAIN WITHIN THE IMMEDIATE WORK AREA FOR EMERGENCY USE.

OHS22900

AUTHORIZED BY - OCCUPATIONAL HEALTH SERVICES, INC. CREATION DATE: 10/25/84 REVISION DATE:'05/02/91

$127-18-4$

TETRACHLOROETHYLENE

Copyright 1991 Occupational Health Services, Inc. All Rights Reserved. Licensed to: Hanford Environmental Health Foundation

To make unlimited paper copies for internal distribution and use only. 
OHS23850

MATERIAL SAFETY DATA SHEET

OCCUPATIONAL HEALTH SERVICES, INC.

11 WEST 42ND STREET, 12TH FLOOR

NEW YORK, NEW YORK 10036

$1-800-445$-MSDS $(1-800-445-6737)$ OR

$1-212-789-3535$
FOR EMERGENCY SOURCE INFORMATION

CONTACT: $1-615-366-2000$

MSDS\#1567

SUBSTANCE IDENTIFICATION

SUBSTANCE: TRICHLOROETHYLENE

CAS-NUMBER 79-01-6

TRADE NAMES/SYNONYMS:

ACETYLENE TRICHLORIDE; ETHYLENE TRICHLORIDE; ALGYLEN;

1-CHLORO-2,2-DICHLOROETHYLENE; 1,1-DICHLORO-2-CHLOROETHYLENE; TCE; ANAMENTH;

ETHINYL TRICHLORIDE; TRICHLOROETHENE; 1,1,2-TRICHLOROETHYLENE;

ETHYLENE, TRICHLORO-; CHLORYLEN; 1,1,2-TRICHLOROETHENE; ETHENE, TRICHLORO-;

NEU-TRI (R) SOLVENT (DOW CHEMICAL); BLACO-TRI (BARON-BLAKESLEE); UN 1710;

RCRA U228; STCC 4941171; C2HCL3; OHS23850

CHEMICAL FAMILY:

HALOGEN COMPOUND, ALIPHATIC

MOLECULAR FORMULA: CL-C-H-C-CL2

MOLECULAR WEIGHT: 131.39

CERCLA RATINGS (SCALE 0-3): HEALTH=3 FIRE =1 REACTIVITY $=0$ PERSISTENCE $=3$ NFPA RATINGS (SCALE 0-4): HEALTH=2 FIRE $=1$ REACTIVITY=0

COMPONENTS AMD CONTAMINANTS

COMPONENT: TRICHLOROETHYLENE

$$
\text { CAS\# 79-01-6 }
$$

PERCENT: $>99$

OTHER CONTAMINANTS: TRACES OF AMINES OR EPOXIDES AS INHIBITORS.

EXPOSURE LIMITS:

TRICHLOROETHYLENE:

50 PPM (269 MG/M3) OSHA TWA; 200 PPM (1070 MG/M3) OSHA STEL

50 PPM $269 \mathrm{MG} / \mathrm{M3}$ ACGIH TWA; $200 \mathrm{PPM}(1070 \mathrm{MG} / \mathrm{M3})$ ACGIH STEL

25 PPM. $134 \mathrm{MG} / \mathrm{M} 3$ NIOSH RECOMMENDED TWA

50 PPM 269 MG/M3 DFG MAK TWA;

250 PPM (1344 MG/M3) DFG MAK 30 MINUTE PEAK, AVERAGE VALUE, 2 TIMES/SHIFT

MEASUREMENT METHOD: CHARCOAL TUBE; CARBON DISULFIDE; GAS CHROMATOGRAPHY WITH

FLAME IONIZATION DETECTION; (NIOSH VOL. III \# 1O22).

100 POUNDS CERCLA SECTION 103 REPORTABLE QUANTITY

SUBJECT TO SARA SECTION 313 ANNUAL TOXIC CHEMICAL RELEASE REPORTING

SUBJECT TO CALIFORNIA PROPOSITION 65 CANCER AND/OR REPRODUCTIVE TOXICITY 
PAGE 2

WARNING AND RELEASE REQUIREMENTS- (APRIL 1, 1988)

PHYSICAL DATA

OESCRIPTION: COLORLESS LIQUID WITH A MILD CHLOROFORM-LIKE ODOR.

BOILING POINT: $189 \mathrm{~F}(87 \mathrm{c})$ MELTING POINT: -99 $\mathrm{F}(-73 \mathrm{c})$ MSDS \# 1567 SPECIFIC GRAVITY: 1.4642 VAPOR PRESSURE: 58 MMHG $\odot 20 \mathrm{C}$

EVAPORATION RATE: (CARBON TETRACHLORIDE=1) 0.69 SOLUBILITY IN WATER: $0.1 \%$

OOOR THRESHOLD: 21 PPM VAPOR DENSITY: 4.53

SOLVENT SOLUBILITY: SOLÜBLE IN ALCOHOL, ETHER, ACETONE, CHLOROFORM, BENZENE AND VEGETABLE OILS.

\section{FIRE AND EXPLOSION DATA}

FIRE AND EXPLOSION HAZARD:

SLIGHT FIRE HAZARD WHEN EXPOSED TO HEAT OR FLAME.

UPPER EXPLOSIVE LIMIT: $52 \%$ ค $100 \mathrm{C}$ LOWER EXPLOSIVE LIMIT: $7.8 \%$ \& $100 \mathrm{C}$

AUTOIGNITION TEMP.: $770 \mathrm{~F}(410 \mathrm{C})$

FIREFIGHTING MEDIA:

DRY CHEMICAL OR CARBON DIOXIDE

(1990 EMERGENCY RESPONSE GUIDEBOOK, DOT P 5800.5).

FOR LARGER FIRES, USE WATER SPRAY, FOG OR REGULAR FOAM

(1990 EMERGENCY RESPONSE GUIDEBOOK, DOT P 5800.5).

FIREFIGHTING:

APPLY COOLING WATER TO SIDES OF CONTAINERS THAT ARE EXPOSED TO FLAMES UNTIL WELL AFTER FIRE IS OUT. STAY AWAY FROM ENDS OF TANKS. ISOLATE FOR $1 / 2$ MILE IN

ALL DIRECTIONS IF TANK, RAIL CAR OR TANK TRUCK IS INVOLVED IN FIRE (1990

EMERGENCY RESPONSE GUIDEBOOK, DOT P 5800.5, GUIDE PAGE 74).

USE AGENT SUITABLE FOR TYPE OF FIRE. AVOID BREATHING TOXIC VAPORS, KEEP UPWIND.

TRANSPORTATION DATA

DEPARTMENT OF TRANSPORTATION HAZARD CLASSIFICATION 49 CFR 172.101:

ORM-A

DEPARTMENT OF TRANSPORTATION LABELING REQUIREMENTS 49 CFR 172.101 AND

SUBPART E:

NONE 
PAGE 3

DEPARTMENT OF TRANSPORTATION PACKAGING REQUIREMENTS: 49 CFR 173.605 EXCEPTIONS: 49 CFR 173.505

\section{TOXICITY}

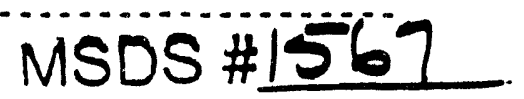

TRICHLOROETHYLENE:

IRRITATION DATA: $2 \mathrm{MG} / 24$ HOURS SKIN-RABBIT SEVERE; $20 \mathrm{MG} / 24$ HOURS EYE-RABBIT MODERATE.

TOXICITY DATA: $6900 \mathrm{MG} / \mathrm{M} 3 / 10$ MINUTES INHALATION-HUMAN TCLO; 160 PPM/83 MINUTES INHALATION-HUMAN TCLO; $812 \mathrm{MG} / \mathrm{KG}$ INHALATION-HUMAN TDLO; 110 PPM/8 HOURS INHALATION-MAN TCLO; 2900 PPM INHALATION-MAN LCLO; 8000 PPM/4 HOURS INHALATION-RAT LCLO; 8450 PPM/4 HOURS INHALATION-MOUSE LC50; 11,000 PPM INHALATION-RABBIT LCLO; $32,500 \mathrm{MG} / \mathrm{M} 3 / 2$ HOURS INHALATION-CAT LCLO; 37,200 PPM/40 MINUTES INHALATION-GUINEA PIG LCLO; 7 GM/KG ORAL-HUMAN LDLO; $2143 \mathrm{MG} / \mathrm{KG}$ ORAL-MAN TDLO; $2402 \mathrm{MG} / \mathrm{KG}$ ORAL-MOUSE LD50; $7330 \mathrm{MG} / \mathrm{KG}$ ORAL-RABBIT LDLO; 5864 MG/KG ORAL-CAT LDLO; 16 GM/KG

SUBCUTANEOUS-MOUSE LD50; $1800 \mathrm{MG} / \mathrm{KG}$ SUBCUTANEOUS-RABBIT LDLO; $150 \mathrm{MG} / \mathrm{KG}$ SUBCUTANEOUS-DOG LDLO; 33,900 UG/KG INTRAVENOUS-MOUSE LD50; $150 \mathrm{MG} / \mathrm{KG}$ INTRAVENOUS-DOG LDLO; $1282 \mathrm{MG/KG}$ INTRAPERITONEAL-RAT LD50; $1900 \mathrm{MG} / \mathrm{KG}$ INTRAPERITONEAL-DOG LD50; MUTAGENIC DATA (RTECS); REPRODUCTIVE EFFECTS DATA (RTECS); TUMORIGENIC DATA (RTECS).

CARCINOGEN STATUS: HUMAN INADEQUATE EVIDENCE, ANIMAL LIMITED EVIDENCE (IARC GROUP-3). REPEATED ORAL ADMINISTRATION PRODUCED HEPATOCELLULAR CARC INOMAS IN MALE AND FEMALE MICE; HEPATOCELLULAR ADENOMAS IN FEMALE MICE; LUNG TUMORS IN MALE AND FEMALE MICE; TUBULAR CELL NEOPLASMS OF THE KIDNEY AND INTERSTITIAL CELL NEOPLASMS OF THE TESTIS IN RATS. INHALATION EXPOSURES RESULTED IN INCREASED INCIDENCES OF LIVER AND LUNG TUMORS IN MALE AND FEMALE MICE AND LOW INCIDENCES OF ADENOCARCINOMAS OF THE RENAL TUBULES IN RATS.

LOCAL EFFECTS: IRRITANT- SKIN, EYE, INHALATION.

ACUTE TOXICITY LEVEL: MODERATELY TOXIC BY INGESTION.

TARGET EFFECTS: CENTRAL NERVOUS SYSTEM DEPRESSANT. POISONING MAY AFFECT THE LIVER, KIDNEYS, LUNG AND HEART.

AT INCREASED RISK FROM EXPOSURE: PERSON WITH PRE-EXISTING HEART OISEASE. ADOITIONAL DATA: THE PRESENCE OF TETRACHLOROETHANE AS AN IMPURITY, OR THE CONSUMPTION OF ALCOHOLIC BEVERAGES, CAFFEINE, OR OTHER DRUGS MAY ENHANCE THE SYSTEMIC TOXICITY. EPIREPHRINE OR OTHER STIMULANTS MAY INDUCE VENTRICULAR ARRHYTHMIAS. MAY CROSS THE PLACENTA. ONE STUDY SHOWS AN INCREASED RISK OF LEUKEMIA FOR CHILDREN WHOSE FATHERS HAD OCCUPATIONAL EXPOSURE TO CHLORINATED SOLVENTS AFTER THE BIRTH OF THE CHILD.

HEALTH EFFECTS AND FIRST AID

INHALATION:

TRICHLOROETHYLENE:

IRRITANT/NARCOTIC.

1000 PPM IMMEDIATELY DANGEROUS TO LIFE OR HEALTH.

ACUTE EXPOSURE- MAY CAUSE MILD IRRITATION OF THE RESPIRATORY TRACT. LEVELS OF 250-1000 PPM HAVE CAUSED IMPAIRED JUDGEMENT AND COORDINATION. 1000-5000 PPM HAS CAUSED EXCITATION FOLLOWED BY CENTRAL NERVOUS SYSTEM DEPRESSION WITH DROWSINESS, DIZZINESS, HEADACHE, NAUSEA, VOMITING, UNCONSCIOUSNESS AND COMA. IF CONSCIOUSNESS IS REGAINED, NAUSEA AND VOMITING MAY FOLLOW FOR SEVERAL HOURS. PSYCHOTIC EFFECTS MAY INCLUDE 
DOE/RL-90-04

\section{MSDS\#1567}

PAGE 4

EUPHORIA, DISORIENTATION, VISUAL OISTURBANCES AND HALLUCINATIONS, AND DELUSIONS. OTHER EFFECTS MAY INCLUDE WEAKNESS, ABDOMINAL CRAMPS, PALLOR, DYSPNEA, TACHYPNEA, IRREGULAR PULSE AND HEARTBEAT, PULMONARY EDEMA, HYPOTENSION, ANESTHESIA, TREMCRS, PROFUSE PERSPIRATION, CYANOSIS, AND RARELY CONVULSIONS. DEATH MAY OCCUR FROM RESPIRATORY ARREST OR VENTRICULAR FIBRILLATION RESULTING IN PRIMARY CARDIAC FAILURE. LIVER AND KIONEY DAMAGE MAY ALSO OCCUR. ANIMAL STUDIES HAVE ALSO SHOWN SPLEEN DAMAGE. TRIGEMINAL NERVE DAMAGE AND HEPATOTOXIC EFFECTS HAVE BEEN ATTRIBUTED TO EXPOSURE TO THE IMPURE SUBSTANCE OR TO THE DECOMPOSITION PRODUCTS.

CHRONIC EXPOSURE- REPEATED EXPOSURE TO LEVELS BELOW 300 PPM MAY CAUSE NAUSEA, VOMITING, HEADACHE, ABDOMINAL CRAMPS, SLEEPINESS, DRUNKENNESS, FLUSHING, ANOREXIA, SWELLING OF THE EYES, FACE AND HANDS, AND MILD CARDIAC ARRHYTHMIAS. OTHER SYMPTOMS MAY INCLUDE WHEEZING, WEIGHT LOSS, ANOREXIA, JOINT AND MUSCLE PAIN, ANEMIA, CRANIAL AND PERIPHERAL NEUROPATHIES, ANEMIA, CHEMICAL HEPATITIS, CIRRHOSIS, AND RARELY JAUNDICE. INTOLERANCE TO ALCOHOL AND TOBACCO, TREMOR, GIDDINESS, ANXIETY AND CARDIAC ARRHYTHMIAS HAVE BEEN FOUND IN WORKERS CHRONICALLY EXPOSED TO 5-630 PPM. LIVER, KIDNEY ANO BRAIN DAMAGE MAY ALSO OCCUR. REPRODUCTIVE EFFECTS HAVE BEEN REPORTED IN ANIMALS. ADMINISTRATION TO MICE WAS ASSOCIATED WITH AN INCREASED INCIDENCE OF LIVER AND LUNG TUMORS AND ADENOCARCINOMAS OF THE RENAL TUBULES IN RATS.

FIRST AID- REMOVE FROM EXPOSURE AREA TO FRESH AIR IMMEDIATELY. IF BREATHING HAS STOPPED, PERFORM ARTIFICIAL RESPIRATION. KEEP PERSON WARM AND AT REST. TREAT SYMPTOMATICALLY AND SUPPORTIVELY. GET MEDICAL ATTENTION IMMEDIATELY.

SKIN CONTACT:

TRICHLOROETHYLENE:

IRRITANT/SENSITIZER.

ACUTE EXPOSURE- MAY CAUSE IRRITATION AND CONTACT DERMATITIS. MAY CAUSE SENSITIZATION IN PREVIOUSLY EXPOSED INDIVIDUALS AND RESULT IN GENERALIZED EXFOLIATAVE OR PAPULOVESICULAR DERMATITIS, AND ERYTHRODERMA. SKIN CONTACT WITH SOAKED CLOTHING FOR A LONG PERIOD OF TIME MAY RESULT IN BLISTERING. MAY BE ABSORBED THROUGH THE SKIN, HOWEVER, DERMAL ABSORPTION IS NOT LIKELY TO BE OF TOXICOLOGICAL SIGNIFICANCE UNDER NORMAL USE.

CHRONIC EXPOSURE- MAY CAUSE A DEFATTING TYPE OF DERMATITIS RESULTING IN ROUGHNESS, CHAPPING, VESICULATION AND SECONDARY INFECTION. REPEATED CONTACT MAY RESULT IN PARALYSIS OF THE FINGERS. SENSITIZATION MAY OCCUR. REPEATED LOW LEVEL EXPOSURE MAY CAUSE INEBRIATION, IRRITABILITY, AND PERSONALITY CHANGES. CHRONIC ABSORPTION MAY ALSO PRODUCE WEIGHT LOSS, NAUSEA, ANOREXIA, FATIGUE, VISUAL IMPAIRMENT, JOINT PAIN AND WHEEZING. JAUNDICE IS RARE.

FIRST AID- REMOVE CONTAMINATED CLOTHING AND SHOES IMMEDIATELY. WASH AFFECTED AREA WITH SOAP OR MILD DETERGENT AND LARGE AMOUNTS OF WATER UNTIL NO EVIDENCE OF CHEMICAL REMAINS (APPROXIMATELY 15-20 MINUTES). GET MEDICAL ATTENTION IMMEDIATELY.

EYE CONTACT:

TRICHLOROETHYLENE:

IRRITANT.

ACUTE EXPOSURE- DIRECT CONTACT WITH VAPOR OR LIQUID MAY CAUSE BURNS OF THE LIDS, CONJUNCTIVA AND CORNEA WITH SYMPTOMS OF REDNESS, TEARING AND BLURRED 
PAGE 5

VISION. A SPLASH IN THE EYE MAY CAUSE SMARTING PAIN AND INJURY TO THE CORNEAL EPITHELIUM WHICH MAY REGENERATE WITH COMPLETE RECOVERY. CHRONIC EXPOSURE- REPEATED AND PROLONGED EXPOSURE MAY CAUSE CONJUNCTIVITIS, CORNEAL INFLAMMATION, OPTIC NEURITIS, DOUBLE VISION, NYSTAGMUS, CHANGES IN COLOR PERCEPTION AND BLINDNESS.

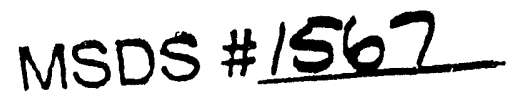

FIRST AID- WASH EYES IMMEDIATELY WITH LARGE AMOUNTS OF WATER OR NORMAL SALINE, OCCASIONALLY LIFTING UPPER AND LOWER LIDS, UNTIL NO EVIDENCE OF CHEMICAL REMAINS (APPROXIMATELY 15-20 MINUTES). GET MEDICAL ATTENTION IMMEDIATELY.

INGESTION: *

TRICHLOROETHYLENE:

NARCOTIC/LIMITED ANIMAL CARCINOGEN.

ACUTE EXPOSURE - MAY CAUSE SEVERE BURNING SENSATION IN THE MOUTH, THROAT, ESOPHAGUS, AND STOMACH, DIARRHEA, INEBRIATION, CONFUSION, TACHYCARDIA, AND CENTRAL NERVOUS SYSTEM DEPRESSION 'WITH DIZZINESS, NAUSEA, VOMITING, HEADACHE, COLLAPSE, CONVULSIONS, AND COMA FOLLOWED BY DEATH FROM RESPIRATORY, CARDIAC OR HEPATORENAL FAILURE. LOW-LEVEL CONCENTRATIONS MAY CAUSE HEADACHE, AMNESIA, NUMBNESS, WEAKNESS OF THE EXTREMITIES, HEMIPARESIS AND PSYCHOSIS.

CHRONIC EXPOSURE- MAY CAUSE IRRITATION OF MUCOUS MEMBRANES, HEADACHE, DROWSINESS, FATIGUE, GIDDINESS, EXCITABILITY, INDIGESTION, NAUSEA, DISTURBANCESS OF SENSATIONS IN THE EXTREMETIES AND OTHER SYMPTOMS NOTED IN CHRONIC INHALATION. REPRODUCTIVE EFFECTS HAVE BEEN REPORTED IN ANIMALS. REPEATED ORAL ADMINISTRATION PROOUCED LIVER AND LUNG TUMORS IN MICE. TUBULAR CELL NEOPLASMS OF THE KIDNEY AND INTERSTITIAL CELL NEOPLASMS OF THE TESTIS WERE OBSERVED IN RATS.

FIRST AID- REMOVE BY GASTRIC LAVAGE OR EMESIS. MAINTAIN BLOOD PRESSURE AND AIRWAY. GIVE OXYGEN IF RESPIRATION IS DEPRESSED. DO NOT PERFORM GASTRIC LAVAGE OR EMESIS IF VICTIM IS UNCONSCIOUS. GET MEDICAL ATTENTION IMMEDIATELY (DREISBACH, HANDBOOK OF POISONING, IITH ED.). ADMINISTRATION OF GASTRIC LAVAGE OR OXYGEN SHOULD BE PERFORMED BY QUALIFIED MEDICAL PERSONNEL.

ANTIDOTE:

NO SPECIFIC ANTIDOTE. TREAT SYMPTOMATICALLY AND SUPPORTIVELY.

REACTIVITY

REACTIVITY:

STABLE UNDER NORMAL TEMPERATURES AND PRESSURES IN A CLOSED CONTAINER. UNINHIBITED MATERIAL, ON HEATING OR EXPOSURE TO LIGHT, MAY DECOMPOSE OR POLYMERIZE, RELEASING HYDROGEN CHLORIDE.

INCOMPATIBILITIES:

TRICHLOROETHYLENE:

ALKALI: FORMS EXPLOSIVE MIXTURE.

ALUMINUM + DILUTE HYDROCHLORIC ACID: VIOLENT POYMERIZATION.

ALUMINUM: VIOLENT DECOMPOSITION MAY OCCUR ON CONTACT WITH ALUMINUM POWDER OR FRESHLY FORMED SURFACES. 
PAGE 6

BARIUM: POSSIBLE DETONATION.

BERYLLIUM: FORMS IMPACT-SENSITIVE MIXTURE.

BORON: FORMS EXPLOSIVE OR IGNITABLE COMPOUND.

1-CHLORO-2,3-EPOXYPROPANE: FORMS EXPLOSIVE MIXTURE.

2, 4-BIS (4 (2', $3^{\prime}$-EPOXYPROPOXY) PHENYL) PROPANE: FORMS EXPLOSIVE MIXTURE.

DI -2,3-EPOXYPROPYL ETHER OF 1,4-BUTANEDIOL: FORMS EXPLOSIVE MIXTURE.

EPOXIDES: POSSIBLE EXPLOSION.

LITHIUM: FORMS IMPACT-SENSITIVE MIXTURE.

MAGNESIUM: FORMS IMPACT-SENSITIVE MIXTURE.

METALS (POWDERED): FORMS EXPLOSIVE OR IGNITABLE COMPOUND.

MONO-2,3-EPOXYPROPYL ETHER OF 1,4-BUTANEDIOL: FORMS EXPLOSIVE MIXTURE.

NITROGEN TETRAOXIDE: FORMS EXPLOSIVE MIXTURE.

OXIDIZERS (STRONG): FIRE AND EXPLOSION HAZARD.

OXYGEN (LIQUID): EXPLODES WHEN INITIATED WITH A BLASTING CAP.

OXYGEN GAS): EXPLODES UNDER PRESSURE AT ROOM TEMPERATURE.

PERCHLORIC ACID: VIOLENT REACTION.

POTASSIUM: FORMS EXPLOSIVE CHLOROACETYLENES.

POTASSIUM HYDROXIDE: FORMS EXPLOSIVE DICHLOROACETYLENE WHEN HEATED.

SODIUM: FORMS EXPLOSIVE CHLOROACETYLENES.

SODIUM HYDROXIDE: FORMS EXPLOSIVE CHLOROACETYLENES.

TITANIUM (POWDER): FORMS IMPACT-SENSITIVE MIXTURE.

DECOMPOSITION:

THERMAL DECOMPOSITION PRODUCTS MAY INCLUDE HIGHLY TOXIC FUMES OF PHOSGENE, TOXIC AND CORROSIVE FUMES OF CHLORIDES, AND OXIDES OF CARBON.

POLYMERIZATION:

MAY POLYMERIZE WHEN CATALYZED BY ALUMINUM CHLORIDE IN A SELF-SUSTAINING

REACTION WHICH MAY DEVELOP TEMPERATURES UP TO 1350 C. A STABILIZER IS

REQUIRED TO PREVENT POLYMERIZATION WHEN HEATED OR EXPOSED TO SUNLIGHT.

STORAGE AND DISPOSAL

OBSERVE ALL FEDERAL, STATE AND LOCAL REGULATIONS WHEN STORING OR DISPOSING OF THIS SUBSTANCE. FOR ASSISTANCE, CONTACT THE DISTRICT DIRECTOR OF THE ENVIRONMENTAL PROTECTION AGENCY.

**STORAGE**

STORE IN A COOL, DRY, WELL-VENTILATED LOCATION, AWAY FROM ANY AREA WHERE THE FIRE HAZARD MAY'BE ACUTE (NFPA 49, HAZARDOUS CHEMICALS DATA, 1975).

STORE AWAY FROM INCOMPATIBLE SUBSTANCES.

*\#ISPOSAL**

DISPOSAL MUST BE IN ACCORDANCE WITH STANDARDS APPLICABLE TO GENERATORS OF HAZARDOUS WASTE, 4OCFR 262. EPA HAZARDOUS WASTE NUMBER U228.

TRICHLOROETHYLENE - REGULATORY LEVEL: $0.5 \mathrm{MG} / \mathrm{L}$

MATERIALS WHICH CONTAIN THE ABOVE SUBSTANCE AT OR ABOVE THE REGULATORY 
PAGE 7

LEVEL MEET THE EPA CHARACTERISTIC OF TOXICITY, AND MUST BE DISPOSED OF IN ACCORDANCE WITH 40 CFR PART 262. EPA HAZARDOUS WASTE NUMBER D040.

MAY BURN BUT DOES NOT IGNITE READILY. CONTAINER MAY EXPLODE IN HEAT OF FIRE.

SOIL SPILL:

DIG A HOLDING AREA SUCH AS A PIT, POND OR LAGOON TO CONTAIN SPILL AND DIKE SURFACE FLOW USING BARRIER OF SOIL, SANDBAGS, FOAMED POLYURETHANE OR FOAMED CONCRETE. ABSORB LIQUID MASS WITH FLY ASH OR CEMENT POWDER.

AIR SPILL:

APPLY WATER SPRAY TO KNOCK DOWN AND REDUCE VAPORS. KNOCK-DOWN WATER IS CORROSIVE AND TOXIC AND SHOULD BE DIKED FOR CONTAINMENT.

WATER SPILL:

USE ACTIVATED CARBON TO ABSORB SPILLED SUBSTANCE THAT IS DISSOLVED.

USE SUCTION HOSES TO REMOVE TRAPPED SPILL MATERIAL.

USE MECHANICAL DREDGES OR LIFTS TO EXTRACT IMMOBILIZED MASSES OF POLLUTION AND PRECIPITATES.

THE CALIFORNIA SAFE DRINKING WATER AND TOXIC ENFORCEMENT ACT OF 1986

(PROPOSITION 65) PROHIBITS CONTAMINATING ANY KNOWN SOURCE OF DRINKING WATER WITH SUBSTANCES KNOWN TO CAUSE CANCER AND/OR REPRODUCTIVE TOXICITY.

OCCUPATIONAL SPILL:

SHUT OFF IGNITION SOURCES. STOP LEAK IF YOU CAN DO IT WITHOUT RISK. FOR SMALL LIQUID SPILLS, TAKE UP WITH SAND, EARTH OR OTHER ABSORBENT MATERIAL. FOR LARGER SPILLS, DIKE FAR AHEAD OF' SPILL FOR LATER DISPOSAL. NO SMOKING, FLAMES OR FLARES IN HAZARD AREA! KEEP UNNECESSARY PEOPLE AWAY.

REPORTABLE QUANTITY (RQ): 100 POUNDS

THE SUPERFUND AMENDMENTS AND REAUTHORIZATION ACT (SARA) SECTION 304 REQUIRES THAT A RELEASE EQUAL TO OR GREATER THAN THE REPORTABLE QUANTITY FOR THIS SUBSTANCE BE IMMEDIATELY REPORTED TO THE LOCAL EMERGENCY PLANNING COMMITTEE AND THE STATE EMERGENCY RESPONSE COMMISSION ( 40 CFR 355.40). IF THE RELEASE OF THIS SUBSTANCE IS REPORTABLE UNDER CERCLA SECTION 103, THE NATIONAL RESPONSE CENTER MUST BE NOTIFIED IMMEDIATELY AT (800) 424-8802 OR (202) 426-2675 IN THE METROPOLITAN WASHINGTON, D.C. AREA (40 CFR 302.6).

VENTILATION:

PROVIDE LOCAL EXHAUST VENTILATION SYSTEM TO MEET PUBLISHED EXPOSURE LIMITS. RESPIRATOR: 
DOE/RL-90-04

\section{MSDS \#1567 PAGE 8}

THE FOLLOWING RESPIRATORS AND MAXIMUM USE CONCENTRATIONS ARE RECOMMENDATIONS BY THE U.S. DEPARTMENT OF HEALTH AND HUMAN SERVICES, NIOSH POCKET GUIDE TO CHEMICAL HAZARDS; NIOSH CRITERIA DOCUMENTS OR BY THE U.S. DEPARTMENT OF LABOR, 29 CFR 1910 SUBPART $Z$.

THE SPECIFIC RESPIRATOR SELECTED MUST BE BASED ON CONTAMINATION LEVELS FOUND IN THE WORK PLACE, MUST NOT EXCEED THE WORKING LIMITS OF THE RESPIRATOR AND BE JOINTLY APPROVED BY THE NATIONAL INSTITUTE FOR OCCUPATIONAL SAFETY AND HEALTH AND THE MINE SAFETY AND HEALTH ADMINISTRATION (NIOSH-MSHA).

TRICHLOROETHYLENE:

AT ANY DETECTABLE CONCENTRATION:

ANY SELF-CONTAINED BREATHING APPARATUS WITH FULL FACEPIECE AND OPERATED IN A PRESSURE-DEMAND OR OTHER POSITIVE PRESSURE MODE. ANY SUPPLIED-AIR RESPIRATOR WITH A FULLFACE-PIECE AND OPERATED IN PRESSURE-DEMAND OR OTHER POSITIVE PRESSURE MODE IN COMBINATION WITH AN AUXILIARY SELF-CONTAINED BREATHING APPARATUS OPERATED IN PRESSURE-DEMAND OR OTHER POSITIVE PRESSURE MODE.

ESCAPE-ANY AIR-PURIFYING FULL FACEPIECE RESPIRATOR (GAS MASK) WITH A CHIN-STYLE OR FRONT- OR BACK-MOUNTED ORGANIC VAPOR CANISTER. ANY APPROPRIATE ESCAPE-TYPE SELF-CONTAINED BREATHING APPARATUS.

FOR FIREFIGHTING AND OTHER IMMEDIATELY DANGEROUS TO LIFE OR HEALTH CONDITIONS:

ANY SELF-CONTAINED BREATHING APPARATUS THAT HAS A FULL FACEPIECE AND IS OPERATED IN A PRESSURE-DEMAND OR OTHER POSITIVE-PRESSURE MODE.

ANY SUPPLIED-AIR RESPIRATOR THAT HAS A FULL FACEPIECE AND IS OPERATED IN A PRESSURE-DEMAND OR OTHER POSITIVE-PRESSURE MODE IN COMBINATION WITH AN AUXILIARY SELF-CONTAINED BREATHING APPARATUS OPERATED IN PRESSURE-DEMAND OR OTHER POSITIVE-PRESSURE MODE.

CLOTHING:

EMPLOYEE MUST WEAR APPROPRIATE PROTECTIVE (IMPERVIOUS) CLOTHING AND EQUIPMENT TO PREVENT REPEATED OR PROLONGED SKIN CONTACT WITH THIS SUBSTANCE.

GLOVES:

EMPLOYEE MUST WEAR APPROPRIATE PROTECTIVE GLOVES TO PREVENT CONTACT WITH THIS SUBSTANCE.

EYE PROTECTION:

EMPLOYEE MUST WEAR SPLASH-PROOF OR DUST-RESISTANT SAFETY GOGGLES TO PREVENT EYE CONTACT WITH THIS SUBSTANCE.

EMERGENCY EYE WASH: WHERE THERE IS ANY POSSIBILITY THAT AN EMPLOYEE'S EYES MAY BE EXPOSED TO THIS SUBSTANCE, THE EMPLOYER SHOULD PROVIDE AN EYE WASH FOUNTAIN WITHIN THE IMMEDIATE WORK AREA FOR EMERGENCY USE.

AUTHORIZED BY - OCCUPATIONAL HEALTH SERVICES, INC. CREATION DATE: $10 / 24 / 84$ REVISION DATE: 06/14/91 
PAGE 9

OHS23850

$79-01-6$

TRICHLOROETHYLENE

\section{MSDS \#1567}

Copyright 1991 Occupational Health Services, Inc. All Rights Reserved.

Licensed to: Hanford Environmental Health Foundation

To make uni imited paper copies for internal distribution and use only. 
OCCUPATIONAL HEALTH SERVICES, INC.

11 WEST 42ND STREET, 12TH FLOOR

NEW YORK, NEW YORK 10036

$1-800-445$-MSDS

$1-212-789-3535$
FOR EMERGENCY SOURCE INFORMATION CONTACT: $1-615-366-2000$

SUBSTANCE IDENTIFICATION

SUBSTANCE: METHYL CHLOROFORM

CAS - NUMBER 71-55-6

TRADE NAMES/SYNONYMS :

1,1,1-TRICHLOROETHANE; ALPHA-TRICHLOROETHANE; AEROTHENE TT;

METHYLTRICHLOROMETHANE; METHYLCHLOROFORM; TRICHLOROMETHYLMETHANE;

TRICHLOROETHANE; ETHANE, 1, 1, 1-TRICHLORO-; CHLORTEN; 1, 1, 1-TRICHLORETHANE;

TRICHLOROETHANE 111 DEGREASE COLD/VAPOR (ASHLAND);

ST-100OA CLEANER (STRESSCOAT); BLACO-TLANE (BARON-BLAKESLEE);

PERM ETHANE DG (DETREX CHEMICALS); SAFETY SOLVENT (LOCTITE CORPORATION);

ACTIVATOR 711, 702, 703 (LOCTITE CORPORATION); STCC 4941176; RCRA U226;

UN 2831; C2H3CL3; OHS 14370

CHEMICAL FAMILY:

HALOGEN COMPOUND, ALIPHATIC

MOLECULAR FORMULA: C-H3-C-CL3

MOLECULAR WEIGHT: 133.40

CERCLA RATINGS (SCALE 0-3): HEALTH=3 FIRE=1 REACTIVITY=0 PERSISTENCE=3 NEPA RATINGS (SCALE 0-4): HEALI: $=3$ FIRE=1 REACTIVITY $=0$

\section{COMPONENTS AND CONTAMINANTS}

COMPONENT: METHYL CHLOROFORM

CAS\# 71-55-6

PERCENT: 100.0

OTHER CONTAMINANTS: NONE

EXPOSURE LIMITS:

METHYL CHLOROFORM (1,1,1-TRICHLOROETHANE) :

350 PPM (1900 MG/M3) OSHA TWA; 450 PPM (2450 MG/M3) OSHA STEL

350 PPM (1900 MG/M3) ACGIH TWA; 450 PPM (2450 MG/M3) ACGIH STEL

350 PPM NIOSH RECOMMENDED 15 MINUTE CEILING

1000 POUNDS CERCLA SECTION 103 REPORTABLE QUANTITY

SUBJECT TO SARA SECTION 313 ANNUAL TOXIC CHEMICAL RELEASE REPORTING

PHYSICAL DATA

DESCRIPTION: CLEAR, COLORLESS LIQUID WITH A MILD CHLOROFORM-LIKE ODOR.

BOILING POINT: $165 \mathrm{~F}(74 \mathrm{C})$ MELTING POINT: $-26 \mathrm{~F}(-32 \mathrm{C})$ 


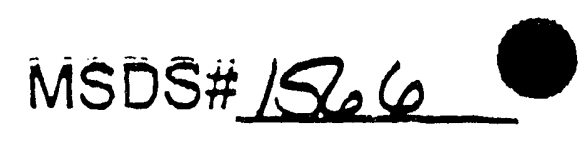

EVAPORATION RATE: (BUTYI ACETATE=1) 5.0 SOLUBILITY IN WATER: $0.078 \%$ @ 25 C ODOR THRESHOLD: 44-100 PPM VAPOR DENSITY: 4.55

SOLVENT SOLUBILITY: SOLUBLE IN ACETONE, BENZENE, CHLOROFORM, METHANOL, ETHANOL, CARBON DISULFIDE, ETHER, CARBON TETRACHLORIDE, N-HEPTANE.

VISCOSITY: $0.858 \mathrm{CPS} @ 20 \mathrm{C}$

\section{FIRE AND EXPLOSION DATA}

FIRE AND EXPLOSION HAZARD:

SLIGHT FIRE HAZARD WHEN EXPOSED TO HEAT OR FLAME.

UPPER EXPLOSIVE LIMIT: $12.5 \%$ LOWER EXPLOSIVE LIMIT: $7.5 \%$

AUTOIGNITION TEMP.: 998 F $(537 \mathrm{C})$

FIREFIGHTING MEDIA:

DRY CHEMICAL OR CARBON DIOXIDE

(1990 EMERGENCY RESPONSE GUIDEBOOK, DOT P 5800.5).

FOR LARGER FIRES, USE WATER SPRAY, FOG OR REGULAR FOAM (1990 EMED.GENCY RESPONSE GUIDEBOOK, DOT P 5800.5).

FIREFIGHTING :

APPLY COOLING WATER TO SIDES OF CONTAINERS THAT ARE EXPOSED TO FLAMES UNTIL WELL AFTER FIRE IS OUT. STAY AWAY FROM ENDS OF TANKS. ISOLATE FOR 1/2 MILE IN ALL DIRECTIONS IF TANK, RAIL CAR OR TANK TRUCK IS INVOLVED IN FIRE $(1990$ EMERGENCY RESPONSE GUIDEBOOK, DOT P 5800.5, GUIDE PAGE 74).

EXTINGUISH USING AGENTS FOR SURROUNDING FIRE. COOL FIRE-EXPOSED CONTAINERS WITH FLOODING AMOUNTS OF WATER APPLIED FROM AS FAR A DISTANCE AS POSSIBLE. DO NOT ALLOW RUN-OFF WATER INTO SEWERS AND WATER SOURCES. AVOID BREATHING VAPORS.

TRANSPORTATION DATA

DEPARTMENT OF TRANSPORTATION HAZARD CLASSIFICATION 49 CFR 172.101: ORM-A

DEPARTMENT OF TRANSPORTATION LABELING REQUIREMENTS 49 CFR 172.101 AND SUBPART $\mathbf{E}$ :

NONE

DEPARTMENT OF TRANSPORTATION PACKAGING REQUIREMENTS: 49 CFR 173.605 EXCERTIONS: 49 CFR 173.505 
METHYL CHLOROFORM (1,1,1-TRICHLOROETHANE):

1 IRRITATION DATA: 450 PPM/8 HOURS EYE-MAN; 5 GM/12 DAYS INTERMITTENT

SKIN-RABBIT MILD; 20 MG/24 HOURS SKIN-RABBIT MODERATE;

100 MG EYE-RABBIT MILD; 2 MG/24 HOURS EYE-RABBIT SEVERE.

TOXICITY DATA: 27 GM/M3/10 MINUTES INHALATION-MAN LCLO;

350 PPM INHALATION-MAN TCLO; 200 PPM/4 HOURS INHALATION-MAN TCLO;

920 PPM/70 MINUTES INHALATION-HUMAN TCLO; 18000 PPM/4 HOURS INHALATION-RAT

PAGE 3

LC50; 3911 PPM/2 HOURS INHALATION-MOUSE LC50; 24400 MG/M3 INHALATION-CAT

LC50; $15800 \mathrm{MG} / \mathrm{KG}$ SKIN-RABBIT LD50 (EPA-600/8-82-003F，1984); $1 \mathrm{GM} / \mathrm{KG}$

SKIN-RABBIT LDLO; $670 \mathrm{MG/KG} \mathrm{ORAL-HUMAN} \mathrm{TDLO;} 10300 \mathrm{MG} / \mathrm{KG}$ ORAL-RAT LD50;

$11240 \mathrm{MG} / \mathrm{KG}$ ORAI-MOUSE LD50; $5660 \mathrm{MG} / \mathrm{KG}$ ORAL-RABBIT LD50;

9470 MG/KG ORAL-GUINEA PIG LD50; 750 MG/KG ORAL-DOG LD50;

$16 \mathrm{GM} / \mathrm{KG}$ SUBCUTANEOUS-MOUSE LD50; $500 \mathrm{MG} / \mathrm{KG}$ SUBCUTANEOUS-RABBIT LDLO;

$95 \mathrm{MG} / \mathrm{KG}$ INTRAVENOUS-DOG LDLO; $3593 \mathrm{MG/KG} \mathrm{INTRAPERITONEAL-RAT} \mathrm{LD50;}$

$3636 \mathrm{MG} / \mathrm{KG}$ INTRAPERITONEAL-MOUSE LD50; $3100 \mathrm{MG} / \mathrm{KG}$ INTRAPERITONEAL-DOG LD50;

MUTAGENIC DATA (RTECS); REPRODUCTIVE EFFECTS DATA (RTECS) .

CARCINOGEN STATUS: ANIMAL INADEQUATE EVIDENCE (IARC GROUP-3).

LOCAL EFFECTS: IRRITANT- INHALATION, SKIN, EYE.

ACUTE TOXICITY LEVEL: SLIGHTLY TOXIC BY INHALATION, DERMAL ABSORPTION AND INGESTION.

TARGET EFFECTS: CENTRAL NERVOUS SYSTEM DEPRESSANT. POISONING MAY ALSO AFFECT

THE HEART, LIVER AND KIDNEYS.

AT INCREASED RISK FROM EXPOSURE: JERSONS WITH PRE-EXISTING SKIN DISORDERS,

LIVER DISEASE OR CARDIOVASCULAR DISEASE.

ADDITIONAL DATA: ALCOHOL MAY ENHANCE THE TOXIC EFEECTS. STIMULANTS SUCH

AS EPINEPHRINE MAY INDUCE VENTRICULAR FIBRILLATION.

HEALTH EFFECTS AND EIRST AID

INHALATION :

METHYL CHLOROFORM (1,1,1-TRICHLOROETHANE) :

IRRITANT/NARCOTIC. 1000 PRM IMMEDIATELY DANGEROUS TO LIFE OR HEALTH.

ACUTE EXPOSURE- EXPOSURE TO 500 PPM FOR 60 MINUTES SHOULD CAUSE NO EFFECT

EXCEPT FOR A DISTINCTIVE ODOR WHILE 900-1000 PPM FOR 20 MINUTES MAY CAUSE MILD RESPIRATORY TRACT IRRITATION AND PROMPT BUT MINIMAL IMPAIRMENT OF EQUILIBRIUM WHICH MAY BE ACCOMPANIED BY HEADACHE, LASSITUDE AND ATAXIA. IMPAIRED PERFORMANCE OF BEHAVIORAL TESTS WAS ALSO REPORTED AT 1000 PPM. HIGHER LEVELS OF 2000-5000 PPM MAY CAUSE INCOORDINATION, ANESTHESIA, EUPHORIA, LOSS OF CONSCIOUSNESS, COMA AND DEATH DUE TO CENTRAL NERVOUS SYSTEM DEPRESSION, RESPIRATORY ARREST, OR CARDIAC ARRYTHMIA.

CARDIAC SENSITIZATION MAY BE A CONTRIBUTING FACTOR. OTHER EFFECTS MAY INCLUDE NAUSEA, VOMITING, DIARRHEA, DROWSINESS, CONVULSIONS, FALL OF BLOOD PRESSURE, LIVER AND KIDNEY DAMAGE, BRADYCARDIA AND BLOOD CLOTTING CHANGES.

CHRONIC EXPOSURE- NO ADVERSE EFFECTS RELATED TO EXPOSURE WERE REPORTED IN VOLUNTEERS EXPOSED TO 500 PQM FOR 7 HOURS A DAY FOR 5 DAYS, OR IN WORKERS EXPOSED TO 200 PPM FOR SEVERAL MONTHS TO 6 YEARS. THERE IS SOME EVIDENCE FROM HIMMAN CASE REPORTS THAT REPEATED EXPOSURE TO HIGH CONCENTRATIONS MAY CAUSE LASTING DAMAGE TO THE HEART. EXPOSURE OF ANIMALS FOR 3 MONTHS AT CONCENTRATIONS FROM 1000 TO 10,000 PPM CAUSED SYMPTOMS OF CENTRAL NERVOUS SYSTEM DEPRESSION AND SOME PATHOLOGICAL CHANGES IN THE LIVERS AND LUNGS OF SOME SPECIES. REPRODUCTIVE EFFECTS APP D-41 


$$
\text { DOE/RL-90-04 }
$$

HAVE BEEN REPORTED IN ANIMALS.

1 FIRST AID- REMOVE FROM EXPOSURE AREA TO FRESH AIR IMMEDIATELY. IF BREATHING HAS STOPPED, GIVE ARTIFICIAL RESPIRATION. MAINTAIN AIRWAY AND BLOOD PRESSURE AND ADMINISTER OXYGEN IF AVAILABLE. KEEP AFFECTED PERSON VIARM AND AT REST. TREAT SYMPTOMATICALLY AND SUPPORTIVELY. ADMINISTRATION OF OXYGEN SHOULD BE PERFORMED BY QUALIFIED PERSONNEL. GET MEDICAL ATTENTION IMMEDIATELY.

SKIN CONTACT:

METHYL CHLOROFORM (1, 1,1-TRICHLOROETHANE) :

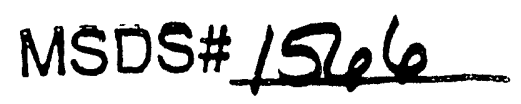
IRRITANT.

ACUTE EXPOSURE- DIRECT CONTACT MAY CAUSE IRRITATION AND REDNESS. VAPORS ARE POORLY ABSORBED, BUT THE LIQUID, ESPECIALLY IF CONFINED UNDER AN

PAGE 4

IMPERMEABLE BARRIER MAY BE ABSORBED TO SOME EXTENT. THIS ALONE IS UNLIKELY TO RESULT IN TOXIC EFEECTS, BUT MAY ADD TO THE EFFECTS OF INHALATION EXPOSURE.

CHRONIC EXPOSURE- REPEATED SKIN CONTACT MAY PRODUCE A DRY, SCALY, FISSURED DERMATITIS DUE TO THE DEFATTING PRORERTIES OF THE LIQUID, AND POSSIBLY BURNS.

FIRST AID- REMOVE CONTAMINATED CLOTHING AND SHOES IMMEDIATELY. WASH AFFECTED AREA WITH SOAP OR MILD DETERGENT AND LARGE AMOUNTS OE WATER UNTIL NO EVIDENCE OF CHEMICAL REMAINS (APPROXIMATELY 15-20 MINUTES). GET MEDICAL ATTENTION IMMEDIATELY.

EYE CONTACT:

METHYL CHLOROFORM (1,1,1-TRICHLOROETHANE) :

IRRITANT.

ACUTE EXPOSURE- EXPOSURE TO 500 PPM MAY CAUSE IRRITATION AND REDNESS. DIRECT CONTACT WITH THE LIQUID MAY CAUSE TEMPORARY INUURY WITH COMPLETE RECOVERY EXPECTED IN 48 HOURS. DIRECT APRLICATION TO THE EYES OF RABBITS HAS CAUSED CONJUNCTIVAL IRRITATION, BUT NO CORNEAL DAMAGE.

CHRONIC EXPOSURE- REPEATED OR PROLONGED CONTACT MAY CAUSE CONUUNCTIVITIS.

FIRST AID- WASH EYES IMMEDIATELY WITH LARGE AMOUNTS OF WATER OR NORMAL SALINE, OCCASIONALIY LIFTING UPPER AND LOWER LIDS, UNTIL NO EVIDENCE OF CHEMICAL REMAINS (APPROXIMATELY 15-20 MINUTES). GET MEDICAL ATTENTION IMMEDIATELY.

INGESTION :

METHYL CHLOROFORM (1,1,1-TRICHLOROETHANE) :

NARCOTIC.

ACUTE EXPOSURE- MAY CAUSE NAUSEA, VOMITING, DIERRHEA, GASTROINTESTINAL DISTURBANCES AND ABDOMINAL PAIN FOLLOWED BY CENTRAL NERVOUS SYSTEM DEPRESSION WITH HEADACHE, DIZZINESS, WEAKNESS, INCOORDINATION, MENTAL CONFUSION AND UNCONSCIOUSNESS. DEATH MAY OCCUR FROM CHRONIC RESPIRATORY FAILURE. OTHER SYMPTOMS AS DESCRIBED IN ACUTE INHALATION MAY ALSO OCCUR. MYOCARDIAL SENSITIZATION TO EPINEPHRINE AND SUBSEQUENT DEATH DUE TO CARDIAC ARREST MAY OCCUR. ASRIRATION MAY RESULT IN PULMONARY EDEMA OR CHEMICAL RNEUMONITIS.

CHRONIC EXPOSURE- REPRODUCTIVE ERFECTS HAVE BEEN REPORTED IN ANIMALS.

$$
\text { APP D-42 }
$$


FIRST AID- IF THE PERSON IS CONSCIOUS AND NOT CONVULSING, INDUCE EMESIS BY GIJING SYRUP OF IPECAC (KEEPING THE HEAD BELOW THE HIPS TO PREVENT ASPIRATION), FOLLOWED BY WATER. REPEAT IN 20 MINUTES IF NOT EFFECTIVE INITIALLY. IN RATIENTS WITH DEPRESSED RESPIRATION OR IF EMESIS IS NOT PRODUCED, PERFORM GASTRIC LAVAGE CAUTIOUSLY (DREISBACH, HANDBOOK OF POISONING, 12TH ED.). TREAT SYMPTOMATICALLY AND SUPPORTIVELY. GASTRIC LAVAGE SHOULD BE PERFORMED BY QUALIFIED MEDICAL PERSONNEL. GET MEDICAL ATTENTION IMMEDIATELY.

ANTIDOTE :

NO SPECIFIC ANTIDOTE. TREAT SYMPTOMATICALIY AND SUPPORTIVELY.

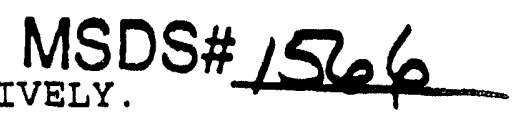

REACTIVITY

REACTIVITY :

SLOWLY DECOMPOSES OVER TIME YIELDING HYDROGEN CHLORIDE. AN INHIBITOR MAY BE ADDED TO SCAVENGE THE ACID THAT IS FORMED AND PREVENT CORROSION TO METALS. WATER MAY REACT WITH THE INHIBITOR AND ALLOW THE NATURAL DECOMPOSITION TO OCCUR.

PAGE 5

INCOMPATIBILITIES :

METHYL CHLOROFORM (1,1,1-TRICHLOROETHANE) : ACETONE: EXOTHERMIC REACTION.

ALRALI (STRONG) : POSSIBLE VIOLENT REACTION.

ALUMINUM AND ALLOYS: MAY DECOMPOSE VIOLENTLY.

BARIUM: FIRE AND EXPLOSION HAZARD.

MAGNESIUM: VIOLENT DECOMPOSITION WITH EVOLUTION OF HYDROGEN CHLORIDE. METALS (POWDERED): FIRE AND EXPLOSION HAZARD.

NITROGEN TETROXIDE: FORMS EXPLOSIVE MIXTURE.

OXIDIZERS (STRONG) : POSSIBLE VIOLENT REACTION.

OXYGEN (GAS): POSSIBLE EXPLOSION WHEN HEATED @ $100 \mathrm{C}$.

OXYGEN (LIQUID) : POSSIBLE VIOLENT EXPLOSION.

POTASH: FORMS FLAMMABLE OR EXPLOSIVE PRODUCT.

POTASSIUM AND ALLOYS: FORMS SHOCK-SENSITIVE MIXTURE.

POTASSIUM HYDROXIDE: FORMATION OF SPONTANEOUSLY FLAMMABLE PRODUCT.

RUBBER, PLASTICS, COATINGS: MAY BE ATTACKED.

SODIUM AND ALLOYS: FIRE AND EXPLOSION HAZARD.

SODIUM HYDROXIDE: FORMS SPONTANEOUSLY FLAMMABLE PRODUCT.

SODIUM-POTASSIUM ALLOY: POSSIBLE EXPLOSION.

TIN AND ALLOYS: INCOMPATIBLE.

ZINC AND ALLOYS: INCOMPATIBLE.

DECOMPOSITION :

THERMAL DECOMPOSITION PRODUCTS MAY INCLUDE TOXIC AND CORROSIVE FUMES OF CHLORIDES, TOXIC FUMES OF PHOSGENE AND CHLOROACETYLENES, AND OXIDES OF CARBON.

POLYMERIZATION :

HAZARDOUS POLYMERIZATION HAS NOT BEEN REPORTED TO OCCUR UNDER NORMAL TEMPERATURES AND PRESSURES. 
OBSERVE ALL FEDERAL, STATE AND LOCAL REGULATIONS WHEN STORING OR DISPOSING OF THIS SUBSTANCE. FOR ASSISTANCE, CONTACT THE DISTRICT DIRECTOR OF THE

1 ENVIRONMENTAL PROTECTION AGENCY.

* * STORAGE* *

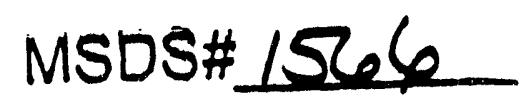

STORE IN A COOL, DRY, WELL-VENTILATED LOCATION, AWAY FROM ANY AREA WHERE THE FIRE - HAZARD MAY BE ACUTE (NEPA 49, HAZARDOUS CHEMICALS DATA, 1975).

STORE AWAY FROM INCOMPATIBLE SUBSTANCES.

$\star \star D I S P O S A L * *$

DISPOSAL MUST BE IN ACCORDANCE WITH STANDARDS APPLICABLE TO GENERATORS OF HAZARDOUS WASTE, 40CFR 262. EPA HAZARDOUS WASTE NUMBER U226.

CONDITIONS TO AVOID

MAY BURN BUT DOES NOT IGNITE READILY. CONTAINER MAY EXPLODE IN HEAT OF FIRE.

SPILL AND LEAK PROCEDURES

SOIL SPILL:

PAGE 6

DIG A HOLDING AREA SUCH AS A PIT, POND OR LAGOON TO CONTAIN SPILL AND DIKE SURFACE FLOW USING BARRIER OF SOIL, SANDBAGS, FOAMED POLYURETHANE OR FOAMED CONCRETE. ABSORB LIQUID MASS WITH FLY ASH OR CEMENT POWDER.

WATER SPILL:

LIMIT SPILL MOTION AND DISPERSION WITH NATURAL BARRIERS OR OIL SPILL CONTROL BOOMS.

TRAP SPILLED MATERIAL AT BOTTOM IN DEEP WATER POCKETS, EXCAVATED HOLDING AREAS OR WITHIN SAND BAG BARRIERS.

USE SUCTION HOSES TO REMOVE TRAPPED SPILL MATERIAL.

THE CALIFORNIA SAFE DRINKING WATER AND TOXIC ENFORCEMENT ACT OF 1986

(DROROSITION 65) PROHIBITS CONTAMINATING ANY KNOWN SOURCE OF DRINKING WATER WITH SUBSTANCES KNOWN TO CAUSE CANCER AND/OR REPRODUCTIVE TOXICITY.

OCCUPATIONAL SPILL:

SHUT OFF IGNITION SOURCES. STOR LEAK IF YOU CAN DO IT WITHOUT RISK. FOR SMALL LIQUID SPILLS, TAKE UP WITH SAND, EARTH OR OTHER ABSORBENT MATERIAL. FOR LARGER SPILLS, DIKE FAR AHEAD OE SPILL FOR LATER DISPOSAL. NO SMOKING, FLAMES OR FLARES IN HAZARD AREA! KEEP UNNECESSARY PEORLE AWAY.

REPORTABLE QUANTITY (RQ) : 1000 POUNDS

THE SUPERFUND AMENDMENTS AND REAUTHORIZATION ACT (SARA) SECTION 304 REQUIRES THAT A RELEASE EQUAL TO OR GREATER THAN THE REPORTABLE QUANTITY FOR THIS SUBSTANCE BE IMMEDIATELY REPORTED TO THE LOCAL EMERGENCY PLANNING COMMITTEE 


$$
\text { DOE/RL-90-04 }
$$

AND THE STATE EMERGENCY RESPONSE COMMISSION (40 CFR 355.40). IF THE RELEASE THIS SUBSTANCE IS REPORTABLE UNDER CERCLA SECTION 103, THE NATIONAL RESPONSE CENTER MUST BE NOTIFIED IMMEDIATELY AT (800) 424-8802 OR (202) 426-2675 IN TH METROPOLITAN WASHINGTON, D.C. AREA (40 CFR 302.6).

\section{PROTECTIVE EQUIRMENT}

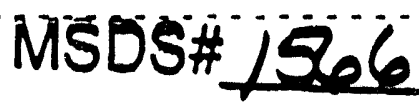

VENTILATION :

PROVIDE GENERAL DILUTION VENTILATION TO MEET PUBLISHED EXPOSURE LIMITS.

RESPIRATOR :

THE FOLLOWING RESPIRATORS AND MAXIMUM USE CONCENTRATIONS ARE RECOMMENDATIONS BY THE U.S. DEPARTMENT OF HEALTH AND HUMAN SERVICES, NIOSH POCKET GUIDE TO CHEMICAL HAZARDS; NIOSH CRITERIA DOCUMENTS OR BY THE U.S. DEPARTMENT OF LABOR, 29 CFR 1910 SUBPART Z.

THE SPECIFIC RESPIRATOR SELECTED MUST BE BASED ON CONTAMINATION LEVELS FOUND IN THE WORK PLACE, MUST NOT EXCEED THE WORKING LIMITS OF THE RESPIRATOR AND BE JOINTLY APRROVED BY THE NATIONAL INSTITUTE FOR OCCUPATIONAL SAFETY AND HEALTH AND THE MINE SAFETY AND HEALTH ADMINISTRATION (NIOSH-MSHA).

METHYL CHLOROFORM $(1,1,1$-TRICHLOROETHANE) :

1000 PPM- ANY SUPPLIED-AIR RESPIRATOR WITH FULL FACEPIECE.

ANY SELF-CONTAINED BREATHING APPARATUS WITH FULL FACEPIECE.

ESCAPE- ANY AIR-PURIFYING FULL FACEPIECE RESPIRATOR (GAS MASR) WITH A CHIN-STYLE OR FRONT OR BACK-MOUNTED ORGANIC VAPOR CANISTER. ANY APPROPRIATE ESCAPE-TYPE SELE-CONTAINED BREATHING APPARATUS.

FOR FIREFIGHTING AND OTHER IMMEDIATELY DANGEROUS TO LIFE OR HEALTH CONDITIONS ANY SELF-CONTAINED BREATHING APPARATUS THAT HAS A FULL FACEPIECE AND IS

PAGE 7

OPERATED IN A PRESSURE-DEMAND OR OTHER POSITIVE-PRESSURE MODE.

ANY SUPPLIED-AIR RESPIRATOR THAT HAS A FULL FACERIECE AND IS OPERATED IN A PRESSURE-DEMAND OR OTHER POSITIVE-PRESSURE MODE IN COMBINATION WITH AN AUXILIARY SELF-CONTAINED BREATHING APPARATUS ORERATED IN PRESSURE-DEMAND OR OTHER POSITIVE-PRESSURE MODE.

CLOTHING :

EMPLOYEE MUST WEAR APPRORRIATE PROTECTIVE (IMPERVIOUS) CLOTHING AND EQUIPMENT TO PREVENT ANY POSSIBILITY OF SKIN CONTACT WITH THIS SUBSTANCE.

\section{GLOVES :}

EMPLOYEE MUST WEAR APPROPRIATE PROTECTIVE GLOVES TO RREVENT CONTACT WITH THIS SUBSTANCE.

EYE PROTECTION:

EMPLOYEE MUST WEAR SPLASH-PROOF OR DUST-RESISTANT SAFETY GOGGLES AND A FACESHIELD TO PREVENT CONTACT WITH THIS SUBSTANCE.

EMERGENCY WASH FACILITIES: APP D-45 
WHERE THERE IS ANY POSSIBILITY THAT AN EMPLOYEE'S EYES AND/OR SKIN MAY BE EXPOSED TO THIS SUBSTANCE, THE EMPLOYER SHOULD PROVIDE AN EYE WASH FOUNTAIN AND QUICK DRENCH SHOWER WITHIN THE IMMEDIATE WORK AREA FOR EMERGENCY USE.

AUTHORIZED BY - OCCUPATIONAL HEALTH SERVICES, INC.

OHS14370

\section{CREATION DATE: $10 / 25 / 84$}

REVISION DATE: $02 / 21 / 91$

$71-55-6$

METHYL CHLOROFORM

\section{MSDS\#1566}

Copyright 1991 Occupational Health Services, Inc.. Licensed to: HEHF

to make unlimited paper copies for internal distribution and use only. 
PAGE 1

OCCUPATIONAL HEALTH SERVICES, INC. 11 WEST 42ND STREET, 12TH FLOOR NEW YORK, NEW YORK 10036 $1-800-445$-MSDS $(1-800-445-6737)$ OR $1-212-789-3535$
FOR EMERGENCY SOURCE INFORMATION CONTACT: $1-615-366-2000$

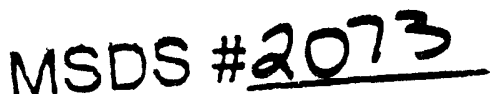

SUBSTANCE IDENTIFICATION

SUBSTANCE: VINYLIDENE CHLORIDE

CAS-NUMBER 75-35-4

TRADE NAMES/SYNONYMS:

1,1-DICHLOROETHENE; 1,1-DICHLOROETHYLENE; VDC; VINYLIDENE CHLORIDE MONOMER; VINYLIDENE DICHLORIDE; RCRA U078; UN 1303; OHS25070

CHEMICAL FAMILY:

HALOGEN

MOLECULAR FORMULA: C2-H2-CL2

MOLECULAR WEIGHT: 96.64

CERCLA RATINGS (SCALE 0-3): HEALTH $=3$ FIRE $=5$ REACTIVITY $=2$ PERSISTENCE $=1$ NFPA RATINGS (SCALE 0-4): HEALTH=2 FIRE =4 REACTIVITY $=2$

COMPONENT: VINYLIDENE CHLORIDE

PERCENT: $>99.9$

$$
\text { CAS\# 75-35-4 }
$$

OTHER CONTAMINANTS: 200 PPM HYDROQUINONE MONOMETHYLETHER ADDED AS AN INHIBITOR.

EXPOSURE LIMITS:

VINYLIDINE CHLORIDE:

1 PPM ( 4 MG/M3) OSHA TWA

5 PPM $20 \mathrm{MG} / \mathrm{M3}$ ) ACGIH TWA; 20 PPM (80 MG/M3) ACGIH STEL

2 PPM 8 MG/M3) DFG MAK TWA;

4 PPM (16 MG/M3) OFG MAK 30 MINUTE PEAK, AVERAGE VALUE, 4 TIMES/SHIFT

100 POUNDS CERCLA SECTION 103 REPORTABLE QUANTITY

SUBJECT TO SARA SECTION 313 ANNUAL TOXIC CHEMICAL RELEASE REPORTING

VINYL HALIDES:

LOWEST DETECTABLE LIMIT NIOSH RECOMMENDED EXPOSURE CRITERIA

PHYSICAL DATA

DESCRIPTION: VOLATILE, COLORLESS LIQUID WITH A MILD SWEET ODOR, WHICH ON LONG 
STANDING MAY FORM WHITE DEPOSITS OF READILY EXPLOSIVE PEROXIDE.

BOILING POINT: $86-90 \mathrm{~F}(30-32 \mathrm{C})$ MELTING POINT: $-188 \mathrm{~F}(-122 \mathrm{C})$

SPECIFIC GRAVITY: 1.213 VAPOR PRESSURE: 400 MMHG $14.8 \mathrm{C}$

EVAPORATION RATE: NOT AVAILABLE SOLUBILITY IN WATER: $0.04 \%$ @ $20 \mathrm{C}$

ODOR THRESHOLD: 500 PPM VAPOR DENSITY: 3.4

SOLVENT SOLUBILITY: ORGANIC SOLVENTS

MSDS \#2075

FIRE AND EXPLOSION DATA

FIRE AND EXPLOSION HAZARD:

DANGEROUS FIRE HAZARD WHEN EXPOSED TO HEAT OR FLAME.

VAPORS ARE HEAVIER THAN AIR AND MAY TRAVEL A CONSIDERABLE DISTANCE TO A SOURCE OF IGNITION AND FLASH BACK.

VAPOR-AIR MIXTURES ARE EXPLOSIVE ABOVE FLASH POINT.

CYLINDER MAY EXPLODE IN HEAT OF FIRE.

FLASH POINT: $14 \mathrm{~F}(-10 \mathrm{C})$ UPPER EXPLOSIVE LIMIT: $11.4 \%$

LOWER EXFLOSIVE LIMT- $6 \%$ AUTOIGNITION TEMP.: 856 F $(457 \mathrm{C})$

FLAMMABILITY CLASS IA

FIREFIGHTING MEDIA:

DRY CHEMICAL, CARBON DIOXIDE, WATER SPRAY OR REGULAR FOAM

(1990 EMERGENCY RESPONSE GUIDEBOOK, DOT P 5800.5).

FOR LARGER FIRES, USE WATER SPRAY, FOG OR REGULAR FOAM

(1990 EMTRGENCY RESPONSE GUIDEBOOK, DOT P 5800.5).

FIREFIGHTING:

MOVE CONTAINER FROM FIRE AREA IF YOU CAN DO IT WITHOUT RISK. APPLY COOLING

WATER TO SIDES OF CONTAINERS THAT ARE EXPOSED TO FLAMES UNTIL WELL AFTER FIRE IS OUT. STAY AWAY FROM ENDS OF TANKS. FOR MASSIVE FIRE IN CARGO AREA, USE UNMANNED HOSE HOLDER OR MONITOR NOZZLES; IF THIS IS IMPOSSIBLE, WITHDRAW FROM AREA AND. LET FIRE BURN. WITHDRAW IMMEDIATELY IN CASE OF RISING SOUND FROM VENTING SAFETY DEVICE OR ANY DISCOLORATION OF TANK DUE TO FIRE. ISOLATE FOR $1 / 2$ MILE IN ALL DIRECTIONS IF TANK, RAIL CAR OR TANK TRUCK IS INVOLVED IN FIRE (1990 EMERGENCY RESPONSE GUIDEBOOK, DOT P 5800.5, GUIDE PAGE 27).

FXTINGUISH ONLY IF FLOW CAN BE STOPPED; USE FLOODING AMOUNTS OF WATER AS A FCG, SOLID STREAMS MAY BE INEFFECTIVE. COOL CONTAINERS WITH FLOODING AMOUNTS OF WATER, AF? LY FROM AS FAR A DISTANCE AS POSSIBLE. AVOID BREATHING VAPORS, KEEP UPWIND. 
WATER MAY BE INEFFECTIVE EXCEPT AS A BLANKET (NFPA 325M, FIRE HAZARD PROPERTIES OF FLAMMABLE LIQUIDS, GASES, AND VOLATILE SOLIDS, 1984)

DEPARTMENT OF TRANSPORTATION HAZARD CLASSIFICATION 49 CFR 172.101: FLAMMABLE LIQUID

DEPARTMENT OF TRANSPORTATION LABELING REQUIREMENTS 49 CFR 172.101 AND SUBPART E:

FLAMMABLE LIQUID

DEPARTMENT OF TRANSPORTATION PACKAGING REQUIREMENTS: 49 CFR 173.119 EXCEPTIONS: 49 CFR 173.118

\section{TOXICITY}

VINYLIDENE CHLORIDE:

TOXICITY DATA: 25 PPM INHALATION-HUMAN TCLO; 6350 PPM/4 HOURS INHALATION-RAT

LC50; $200 \mathrm{MG} / \mathrm{KG}$ ORAL-RAT LD50; $194 \mathrm{MG} / \mathrm{KG}$ ORAL-MOUSE LD50; $5750 \mathrm{MG} / \mathrm{KG}$

ORAL-DOG LDLO; $3700 \mathrm{MG} / \mathrm{KG}$ SUBCUTANEOUS-RABBIT LDLO; $225 \mathrm{MG} / \mathrm{KG}$

INTRAVENOUS-DOG LDLO; MUTAGENIC DATA (RTECS); REPRODUCTIVE EFFECTS DATA (RTECS); TUMORIGENIC DATA (RTECS).

CARCINOGEN STATUS: HUMAN INADEQUATE EVIDENCE. ANIMAL LIMITED EVIDENCE (IARC GROUP-3). THE AVAILABLE EXPERIMENTAL EVIDENCE INDICATES THAT

VINYLIDENE CHLORIDE PROOUCES MALIGNANT TUMORS IN MICE AND RATS BY INHALATION AND THAT SOME OF THE TUMORS ARE SIMILAR TO THOSE PRODUCED BY VINYL CHLORIDE.

THE AVAILABLE DATA WAS NOT ADEQUATE AN EVALUATION OF HUMAN CARCINOGENICITY. LOCAL EFFECTS: IRRITANT- INHALATION, SKIN, EYE.

ACUTE TOXICITY LEVEL: TOXIC BY INGESTION; MODERATELY TOXIC BY INHALATION.

TARGET EFFECTS: CENTRAL NERVOUS SYSTEM DEPRESSANT; HEPATOTOXIN.

\section{HEALTH EFFECTS AND FIRST AID}

INHALATION:

VINYLIDENE CHLORIDE:

IRRITANT/NARCOTIC/MEPATOTOXIN/LIMITED ANIMAL CARCINOGEN.

ACUTE EXPOSURE- INHALATION MAY IRRITATE THE NOSE AND RESPIRATORY SYSTEM AND CAUSE LUNG CONGESTION. HIGH CONCENTRATIONS (AROUND 4000 PPM) NAY CAUSE CENTRAL NERVOUS SYSTEM DEPRESSION WITH SYMPTOMS OF INEBRIATION, WHICH MAY PROGRESS TO CONVULSIONS, SPASMS, AND UNCONSCIOUSNESS, AND POSSIBLY DEATH. IF NOT FATAL, COMPLETE RECOVERY OCCURS IF EXPOSURE IS STOPPED. CHRONIC EXPOSURE- REPEATED OR PROLONGED EXPOSURE HAS PRODUCED A SIGNIFICANT INCREASE IN KIDNEY ADENOCARCINOMAS, MAMMARY CARCINOMAS AND PULMONARY ADENOMAS IN MICE. WORKERS EXPOSED FOR UP TO 6 YEARS REVEALED A HIGH INCIDENCE OF HEPATOTOXICITY. 4 HOUR EXPOSURE OF 200 PPM PRODUCED EXTENSIVE HEMORRHAGIC CENTROLOBULAR LIVER NECROSIS IN RATS 6 HOURS AFTER EXPOSURE. MAY ALSO CAUSE KIDNEY DAMAGE, AND REPRODUCTIVE EFFECTS HAVE BEEN REPORTED IN ANIMALS.

FIRST AID- REMOVE FROM EXPOSURE AREA TO FRESH AIR IMMEDIATELY. IF BREATHING 
HAS STOPPED, PERFORM ARTIFICIAL RESPIRATION. KEEP PERSON WARM AND AT REST. TREAT SYMPTOMATICALLY AND SUPPORTIVELY. GET MEDICAL ATTENTION IMMEDIATELY.

SKIN CONTACT:

VINYLIDENE CHLORIDE:

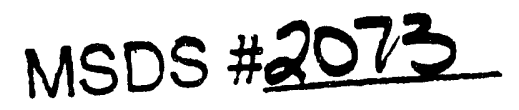

IRRITANT.

ACUTE EXPOSURE- THE LIQUID MAY IRRITATE THE SKIN. WHERE LEAKS OCCUR, VINYLIDENE CHLORIDE MAY EVAPORATE AND THE HYDROQUINONE MONOMETHYLETHER INHIBITOR MAY ACCUMULATE UNTIL IT REACHES A CONCENTRATION CAPABLE OF CAUSING LOCAL BURNS.

CHRONIC EXPOSURE- REPEATED OR PROLONGED EXPOSURE TO IRRITANTS MAY CAUSE DERMATITIS. AS EVALUATED BY RTECS, ADMINISTRATION TO MICE BY SKIN CONTACT RESULTED IN A STATISTICALLY SIGNIFICANT INCREASE IN THE INCIDENCE OF NEOPLASTIC TUMORS OF THE RESPIRATORY TRACT AND SKIN.

FIRST AID- REMOVE CONTAMINATED CLOTHING AND SHOES IMMEDIATELY. WASH AFFECTED AREA WITH SOAP OR MILD DETERGENT AND LARGE AMOUNTS OF WATER UNTIL NO EVIDENCE OF CHEMICAL REMAINS (APPROXIMATELY 15-20 MINUTES). GET MEDICAL ATTENTION IMMEDIATELY.

EYE CONTACT:

VINYLIDENE CHLORIDE:

IRRITANT.

ACUTE EXPOSURE - CONTACT WITH THE EYE MAY CAUSE PAIN, CONJUNCTIVAL IRRITATION, AND TRANSIENT CORNEAL INJURY. HIGH LEVELS OF THE PHENOLIC INHIBITOR MAY POSSIBLY CAUSE BURNS.

CHRONIC EXPOSURE- REPEATED OR PROLONGED EXPOSURE TO IRRITANTS MAY CAUSE CONJUNCTIVITIS.

FIRST AID- WASH EYES IMMEDIATELY WITH LARGE AMOUNTS OF WATER OR NORMAL SALINE, OCCASIONALLY LIFTING UPPER AND LOWER LIDS, UNTIL NO EVIDENCE OF CHEMICAL REMAINS (APPROXIMATELY 15-20 MINUTES). GET MEDICAL ATTENTION IMMEDIATELY.

INGESTION:

VINYLIDENE CHLORIDE:

NARCOTIC/HEPATOTOXIN/TOXIC

ACUTE EXPOSURE- IT MAY CAUSE CENTRAL. NERVOUS SYSTEM DEPRESSION, COUGHING, DIZZINESS, DULLNESS, AND UNCONSCIOUSNESS. IT MAY CAUSE HISTOLOGICAL CHANGES IN THE LIVER AND KIDNEYS.

CHRONIC EXPOSURE- REPEATED OR PROLONGED INGESTION MAY CAUSE KIDNEY OR LIVER DAMAGE.

FIRST AID- TREAT SYMPTOMATICALLY AND SUPPORTIVELY. GET MEDICAL ATTENTION IMMEDIATELY. IF VOMITING OCCURS, KEEP HEAD LOWER THAN HIPS TO PREVENT ASPIRATION.

ANTIDOTE:

NO SPECIFIC ANTIDOTE. TREAT SYMPTOMATICALLY AND SUPPORTIVELY.

REACTIVITY

REACTIVITY: 
PAGE 5

VINYLIDENE CHLORIDE IN THE PRESENCE OF AIR OR OXYGEN WITH THE INHIBITOR REMOVED, FORMS A COMPLEX PEROXIDE COMPOUND AT TEMPERATURES BETWEEN - 40 AND +25 C. THE PEROXIDE IS VIOLENTLY EXPLOSIVE. LOSS OF INHIBITOR OR EXCESSIVE HEAT OR LIGHT MAY CAUSE SPONTANEOUS POLYMERIZATION RESULTING IN VIOLENT CONTAINER RUPTURE.

INCOMPATIBILITIES:

VINYLIDENE CHLORIDE:

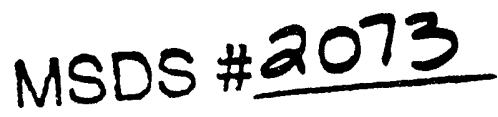

AIR: WITH THE INHIBITOR REMOVED AND ON LONG STANDING IT FORMS EXPLOSIVE PEROXIDES.

ALUMINUM: CAN CATALYZE POLYMERIZATION.

CHLOROSULFONIC ACID: VIOLENT REACTION.

COPPER: CAN CATALYZE POLYMERIZATION.

NITRIC ACID: VIOLENT REACTION.

OLEUM: VIOLENT REACTION.

OXIDIZING AGENIS: INCOMPATIBLE.

DECOMPOSITION;

THERMAL DECOMPOSITION PRODUCTS MAY INCLUDE HIGHLY TOXIC FUMES OF PHOSGENE, TOXIC AND CORROSIVE FUMES OF CHLORIDES, AND OXIDES OF CARBON.

POLYMERIZATION:

VINYLIDENE CHLORIDE:

LOSS OF INHIBITOR OR EXCESSIVE HEAT OR LIGHT MAY CAUSE SPONTANEOUS

POLYMERIZATION RESULTING IN VIOLENT CONTAINER RUPTURE. POLYMERIZATION MAY OCCUR IN THE PRESENCE OF ALUMINUM OR COPPER OR THEIR ALLOYS OR AIR.

STORAGE AND DISPOSAL

OBSERVE ALL FEDERAL, STATE AND LOCAL REGULATIONS WHEN STORING OR DISPOSING OF THIS SUBSTANCE. FOR ASSISTANCE, CONTACT THE DISTRICT DIRECTOR OF THE ENYIRONMENTAL PROTECTION AGENCY.

**DISPOSAL **

DISPOSAL MUST BE IN ACCORDANCE WITH STANDARDS APPLICABLE TO GENERATORS OF HAZARDOUS WASTE, 4OCFR 262. EPA HAZARDOUS WASTE NUMBER U078.

1,1-DICHLOROETHYLENE - REGULATORY LEVEL: $0.7 \mathrm{MG} / \mathrm{L}$ MATERIALS WHICH CONTAIN THE ABOVE SUBSTANCE AT OR ABOVE THE REGULATORY LEVEL MEET THE EPA CHARACTERISTIC OF TOXICITY, AND MUST BE DISPOSED OF IN ACCORDANCE WITH 40 CFR PART 262. EPA HAZARDOUS WASTE NUMBER D029.

\section{CONDITIONS TO AVOID}

AVOID CONTACT WITH HEAT, SPARKS, FLAMES, OR OTHER SOURCES OF IGNITION. VAPORS MAY BE EXPLOSIVE. AVOID OVERHEATING OF CONTAINERS; CONTAINERS MAY VIOLENTLY RUPTURE IN HEAT OF FIRE. AVOID CONTAMINATION OF WATER SOURCES. 
PAGE 6

SPILL AND LEAK PROCEDURES

SOIL SPILL:

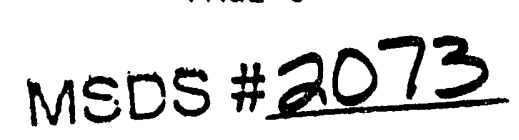

DIG A HOLDING AREA SUCH AS PIT, POND OR LAGOON TO CONTAIN SPILL AND DIKE SURFACE FLOW WITH BARRIER OF SOIL, SANDBAGS, FOAMED POLYURETHANE OR FOAMED CONCRETE.

ABSORB BULK LIQUID WITH FLY ASH, CEMENT POWDER, SAWDUST, OR COMMERCIAL SORBENTS.

APPLY FLUOROCARBON-WATER FOAM TO REDUCE VAPOR AND FIRE HAZARD.

AIR SPILL:

KNOCK DOWN VAPORS WITH WATER SPRAY. KEEP UPWIND.

COMBUSTION PRODUCTS INCLUDE CORROSIVE OR TOXIC VAPORS.

WATER SPILL:

USE NATURAL DEEP WATER POCKETS, EXCAVATED LAGOONS, OR SAND BAG BARRIERS TO TRAP MATERIAL AT BOTTOM.

APPLY UNIVERSAL GELLING AGENT TO IMMOBILIZE TRAPPED SPILL AND INCREASE EFFICIENCY OF REMOVAL.

USE MECHANICAL DREDGES OR LIFTS TO EXTRACT IMMOBILIZED MASSES OF POLLUTION AND PRECIPITATES.

OCCUPATIONAL SPILL:

SHUT OFF IGNITION SOURCES. STOP LEAK IF YOU CAN DO IT WITHOUT RISK. USE WATER

- SPRAY TO REDUCE VAPORS. FOR SMALL SPILLS, TAKE UP WITH SAND OR OTHER ABSORBENT MATERIAL AND PLACE INTO CONTAINERS FOR LATER DISPOSAL. FOR LARGER SPILLS, DIKE FAR AHEAD OF SPILL FOR LATER DISPOSAL. NO SMOKING, FLAMES OR FI ARES IN HAZARD AREA. KEEP UNNECESSARY PEOPLE AWAY; ISOLATE HAZARD AREA AND RESTRICT ENTRY.

REPORTABLE QUANTITY (RQ): 100 POUNDS

THE SUPERFUND AMENDMENTS AND REAUTHORIZATION ACT (SARA) SECTION 304 REQUIRES

THAT A RELEASE EQUAL TO OR GREATER THAN THE REPORTABLE QUANTITY FOR THIS

SUBSTANCE BE IMMEDIATELY REPORTED TO THE LOCAL EMERGENCY PLANNING COMMITTEE AND THE STATE EMERGENCY RESPONSE COMMISSION (40 CFR 355.40). IF THE RELEASE OF THIS SUBSTANCE IS REPORTABLE UNDER CERCLA SECTION 103, THE NATIONAL RESPONSE CENTER MUST BE NOTIFIED IMMEDIATELY AT (800) 424-8802 OR (202) 426-2675 IN THE METROPOLITAN WASHINGTON, D.C. AREA (40 CFR 302.6).

VENTILATION:

PROVIDE LOCAL EXHAUST OR PROCESS ENCLOSURE VENTILATION TO MEET THE PUBLISHED EXPOSURE LIMITS. VENTILATION EQUIPMENT MUST BE EXPLOSION-PROOF.

RESPIRATOR:

THE FOLLOWING RESPIRATORS ARE RECOMMENDED BASED ON INFORMATION FOUND IN THE PHYSICAL DATA, TOXICITY AND HEALTH EFFECTS SECTIONS. THEY ARE RANKED IN ORDER FROM MINIMUM TO MAXIMUM RESPIRATORY PROTECTION. 


\section{MSOS\#2073 PAGE 7}

THE SPECIFIC RESPIRATOR SELECTED MUST BE BASED ON CONTAMINATION LEVELS FOUND IN THE WORK PLACE, MUST BE BASED ON THE SPECIFIC OPERATION, MUST NOT EXCEED THE WORKING LIMITS OF THE RESPIRATOR AND MUST BE JOINTLY APPROVED BY THE NATIONAL INSTITUTE FOR OCCUPATIONAL SAFETY AND HEALTH AND THE MINE SAFETY AND HEALTH ADMINISTRATION (NIOSH-MSHA).

ANY TYPE ' $C$ ' SUPPLIED-AIR RESPIRATOR WITH A FULL FACEPIECE OPERATED IN PRESSURE-DEMAND OR OTHER POSITIVE PRESSURE MODE OR WITH A FULL FACEPIECE, HELMET OR HOOD OPERATED IN CONTINOUS-FLOW MODE.

ANY SELF-CONTAINED BREATHING APPARATUS WITH A FULL FACEPIECE OPERATED IN PRESSURE-DEMAND OR OTHER POSITIVE PRESSURE MODE.

FOR FIREFIGHTING AND OTHER IMMEDIATELY DANGEROUS TO LIFE OR HEALTH CONDITIONS:

ANY SELF-CONTAINED BREATHING APPARATUS THAT HAS A FULL FACEPIECE AND IS OPERATED IN A PRESSURE-DEMAND OR OTHER POSITIVE-PRESSURE MODE.

ANY SUPPLIED-AIR RESPIRATOR THAT HAS A FULL FACEPIECE AND IS OPERATED IN A PRESSURE-DEMAND OR OTHER POSITIVE-PRESSURE MODE IN COMBINATION WITH AN AUXILIARY SELF-CONTAINED BREATHING APPARATUS OPERATED IN PRESSURE-DEMAND OR OTHER POSITIVE-PRESSURE MODE.

CLOTHING:

EMPLOYEE MUST WEAR APPROPRIATE PROTECTIVE (IMPERVIOUS) CLOTHING AND EQUIPMENT TO PREVENT REPEATED OR PROLONGED SKIN CONTACT WITH THIS SUBSTANCE.

GLOVES:

EMPLOYEE MUST WEAR APPROPRIATE PROTECTIVE GLOVES TO PREVENT CONTACT WITH THIS SUBSTANCE.

EYE PROTECTION:

EMPLOYEE MUST WEAR SPLASH-PROOF OR DUST-RESISTANT SAFETY GOGGLES TO PREVENT

EYE CONTACT WITH THIS SUBSTANCE.

EMERGENCY EYE WASH: WHERE THERE IS ANY POSSIBILITY THAT AN EMPLOYEE'S EYES MAY BE. EXPOSED TO THIS SUBSTANCE, THE EMPLOYER SHOULD PROVIDE AN EYE WASH FOUNTAIN WITHIN THE IMMEDIATE WORK AREA FOR EMERGENCY USE.

5070

AUTHORIZED BY - OCCUPATIONAL HEALTH SERVICES, INC. CREATION DATE: 03/02/87 REVISION DATE: $04 / 11 / 91$

75-35-4

VINYLIDENE CHLORIDE

Copyright 1991 Occupational Health Services, Inc. All Rights Reserved.

Licensed to: Hanford Environmental Health Foundation

To make unlimited paper copies for internal distribution and use only. 
PAGE 1

OHSO5125

MATERIAL SAFETY DATA SHEET

MSDS \#2015

OCCUPATIONAL HEALTH SERVICES, INC.

11 WEST 42ND STREET, 12TH FLOOR

FOR EMERGENCY SOURCE INFORMATION NEW YORK, NEW YORK 10036

$1-800-445-M S D S(1-800-445-6737)$ OR

$1-212-789-3535$

SUBSTANCE IDENTIFICATION

SUBSTANCE: CIS-1,2-DICHLOROETHYLENE

CAS-NUMBER 156-59-2

TRADE NAMES/SYNONYMS:

CIS-ACETYLENE DICHLORIDE; 1,2-DICHLOROETHYLENE; UN 1150; OHS05125

CHEMICAL FAMILY:

HALOGEN COMPOUND, ALIPHATIC

MOLECULAR FORMULA: C2-H2-CL2

MOLECULAR WEIGHT: 96.94

CERCLA RATINGS (SCALE 0-3): HEALTH $=2$ FIRE $=3$ REACTIVITY $=2$ PERSISTENCE $=1$ NFPA RATINGS (SCALE 0-4): HEALTH $=2$ FIRE $=3$ REACTIVITY $=2$

CONPONENTS AND CONTAMINANTS

COMPONENT: CIS-1,2-DICHLOROETHYLENE

PERCENT: 100

$$
\text { CAS\# } 156-59-2
$$

OTHER CONTAMINANTS: NONE

EXPOSURE LIMITS:

1,2-DICHLOROETHYLENE (ALL ISOMERS):

200 PPM (793 MG/M3) OSTIA TWA

200 PPM $793 \mathrm{MG} / \mathrm{MB}$ ACGIH TWA

200 PPM 793 MG/M3 NIOSH RECOMMENDOED TWA

200 PPM 793 MG/M3 DFG MAK TWA;

400 PPM (1586 MG/M3) DFG MAK 30 MINUTE PEAK, AVERAGE VALUE, 4 TIMES/SHIFT

MEASUREMENT METHOD: CHARCOAL TUBE/CARBON DISULFIDE; GAS CHROMATOGRAPHY WITH FLAME IONIZATION DETECTION; (NIOSH VOL. III \# 1003, HALOGENATED HYOROCARBONS).

SUBJECT TO SARA SECTION 313 ANNUAL TOXIC CHEMICAL RELEASE REPORTING

PHYSICAL DATA

DESCRIPTION: COLORLESS LIQUID WITH A PLEASANT ODOR. 
BOILING POINT: $140 \mathrm{~F}(60 \mathrm{C})$ MELTING POINT: $-114 \mathrm{~F} \quad(-81 \mathrm{C})$

SPECIFIC GRAVITY: 1.2837 VAPOR PRESSURE: 400 MMHG $41 \mathrm{C}$

SOLUBILITY IN WATER: INSOLUBLE VAPOR DENSITY: 3.34

SOLVENT SOLUBILITY: ACETONE, BENZENE, ETHER, ALCOHOL

MSDS \#2015

\section{FIRE AND EXPLOSION DATA}

FIRE AND EXPLOSION HAZARD:

DANGEROUS FIRE HAZARD WHEN EXPOSED TO HEAT OR FLAME.

VAPOR-AIR MIXTURES ARE EXPLOSIVE ABOVE FLASH POINT.

VAPORS ARE HEAVIER THAN AIR AND MAY TRAVEL A CONSIDERABLE DISTANCE TO A SOURCE OF IGNITION AND FLASH BACK.

FLASH POINT: $39 \mathrm{~F}(4 \mathrm{C})(\mathrm{CC})$ UPPER EXPLOSIVE LIMIT: 12.8

LOWER EXPLOSIVE LIMIT: 9.7 FLAMMABILITY CLASS(OSHA): IB

FIREFIGHTING MEDIA:

DRY CHEMICAL, CARBON DIOXIDE, WATER SPRAY OR REGULAR FOAM

(1990 EMERGENCY RESPONSE GUIDEBOOK, DOT P 5800.5).

FOR LARGER FIRES, USE WATER SPRAY, FOG OR REGULAR FOAM

( 1990 EMERGENCY RESPONSE GUIDEBOOK, DOT $P$ 58J0.5).

FIREFIGHTING :

MOVE CONTAINER FROM FIRE AREA IF YOU CAN DO IT WITHOUT RISK. APPLY COOLING

WATER TO SIDES OF CONTAINERS THAT ARE EXPOSED TO FLAMES UNTIL WELL AFTER FIRE

IS OUT. STAY AWAY FROM ENDS OF TANKS. FOR MASSIVE FIRE IN CARGO AREA, USE UNMANNED HOSE HOLDER OR MONITOR NOZZLES; IF THIS IS IMPOSSIBLE, WITHDRAW FROM

AREA AND LET FIRE BURN. WITHDRAW IMMEDIATELY IN CASE OF RISING SOUND FROM

VENTING SAFETY DEVICE OR ANY DISCOLORATION OF TANK DUE TO FIRE. ISOLATE FOR

$1 / 2$ MILE IN ALL DIRECTIONS IF TANK, RAIL CAR OR TANK TRUCK IS INVOLVED IN FIRE

(1990 EMERGENCY RESPONSE GUIDEBOOK, DOT P 5800.5, GUIDE PAGE 27).

EXTINGUISH ONLY IF FLOW CAN BE STOPPED; USE FLOODING AMOUNTS OF WATER AS A FOG, SOLID STREAMS MAY BE INEFFECTIVE. COOL CONTAINERS WITH FLOODING

AMOUNTS OF WATER, APPLY FROM AS FAR A DISTANCE AS POSSIBLE. AVOID BREATHING VAPORS, KEEP UPWIND.

TRANSPORTATION DATA

DEPARTMENT OF TRANSPORTATION HAZARD CLASSIFICATION 49 CFR 172.101:

FLAMMABLE LIQUID

DEPARTMENT OF TRANSPORTATION LABELING REQUIREMENTS 49 CFR 172.101 AND

SUBPART E:

FLAMMABLE LIQUID 
DEPARTMENT OF TRANSPORTATION PACKAGING REQUIREMENTS: 49 CFR 173.119 EXCEPTIONS: 49 CFR 173.118

CIS-1,2-DICHLOROETHYLENE:

$65000 \mathrm{MG} / \mathrm{M} 3 / 2$ HOURS INHALATION-MOUSE LCLO; $20000 \mathrm{MG} / \mathrm{M} 3 / 6$ HOURS INHALATION-CAT LCLO; MUTAGENIC DATA (RTECS); CARCINOGEN STATUS: NONE.

CIS-1,2-DICHLOROETHYLENE IS A CENTRAL NERVOUS SYSTEM DEPRESSANT AND AN EYE, MUCOUS MEMBRANE, AND SKIN IRRITANT. STIMULANTS SUCH AS EPINEPHRINE AND EPHEDRINE MAY ENHANCE THE TOXICITY OF SOME HALOGENATED HYDROCARBONS. PERSONS WITH CHRONIC RESPIRATORY DISEASE MAY BE AT AN INCREASED RISK FROM EXPOSURE.

INHALATION:

1,2-DICHLOROETHYLENE (ALL ISOMERS):

IRRITANT/NARCOTIC. 4000 PPM IMMEDIATELY DANGEROUS TO LIFE OR HEALTH.

ACUTE EXPOSURE- VAPOR EXPOSURE MAY CAUSE MUCOUS MEMBRANE IRRITATION, NAUSEA, VOMITING, DIZZINESS, WEAKNESS, TREMOR, AND EPIGASTRIC CRAMPS. HIGHER LEVELS MAY CAUSE CENTRAL NERVOUS SYSTEM DEPRESSION RANGING FROM DROWSINESS TO UNCONSCIOUSNESS. THE CIS- AND TRANS- ISOMERS TOGETHER HAVE BEEN USED AS AN ANESTHETIC IN MAN. A HUMAN DEATH HAS BEEN REPORTED FROM INDUSTRIAL EXPOSURE. AN 8 HOUR EXPOSURE TO THE TRANS- ISOMER AT 200 PPM LOWERED THE LEUKOCYTE COUNT IN RATS; 1000 PPM CAUSED A FALL IN THE BLOOD SERUM ALBUMIN, UREA NITROGEN, ALKALINE PHOSPHATASE ACTIVITY, AND THE NUMBER OF ERYTHROCYTES. NARCOSIS WAS NOT PRODUCED AT THESE LEVELS. 3000 PPM PRODUCED FIBROUS SWELLING OF THE CARDIAC MUSCLE AND HYPEREMIA WHICH PERSISTED FOR 14 HOURS AFTER EXPOSURE. THE CIS- ISOMER DID NOT ANESTHETIZE RATS IN 4 HOURS AT 8000 PPM, BUT AT 16,000 PPM THEY WERE ANESTHETIZED IN 8 MINUTES AND KILLED IN 4 HOURS. REVERSIBLE SUPERFICIAL CORNEAL TURBIDITY HAS BEEN OBSERVED IN SOME ANESTHETIZED DOGS.

CHRONIC EXPOSURE- VARIATIONS IN DATA EXIST ON THE CHRONIC TOXICITY OF THE CIS- AND TRANS- ISOMERS. RATS EXPOSED TO 200 PPM OF THE TRANS- ISOMER FOR 8 HOURS/DAY, 5 DAYS/WEEK FOR 16 WEEKS SHOWED HISTOLOGICAL EVIDENCE OF SLIGHT TO SEVERE FATTY DEGENERATION OF LIVER LOBULES AND KUPFFER CELLS, MARKED PULMONARY HYPEREMIA, ALVEOLAR SEPTAL DISTENSION AND FIBROUS SWELLING OF THE CARDIAC MUSCLE. SIMILAR EXPOSURES WITH RATS, GUINEA PIGS, RABBITS AND DOGS EXPOSED TO 500 PPM OR 1000 PPM 7 HOURS/DAY, 5 DAYS/WEEK FOR 6 MONTHS TO A MIXTURE OF 60\% CIS- AND 40\% TRANS- ISOMERS RESULTED IN NO ADVERSE EFFF.CTS DETECTED. CATS AND RABBITS WERE REPEATEDLY EXPOSED TO VAPOR CONCENTRATIONS OF $0.16-0.19 \%$ IN AIR. THE CIS- ISOMER CAUSED ANOREXIA, DECREASED BODY WEIGHT AND PATHOLOGICAL CHANGES IN THE LUNGS, LIVER, AND KIDNEYS. THE TRANS- ISOMER CAUSED ANOREXIA AND SOME RESPIRATORY IRRITATION, BUT NO HISTOPATHOLOGICAL CHANGES IN ORGANS.

FIRST AID- REMOVE FROM EXPOSURE AREA TO FRESH AIR IMMEDIATELY. IF BREATHING HAS STOPPED, PERFORM ARTIFICIAL RESPIRATION. KEEP PERSON WARM AND AT REST. TREAT SYMPTOMATICALLY ANE SUPPORTIVELY. GET MEDICAL ATTENTION IMMEDIATELY. 
PAGE 4

SKIN CONTACT:

1,2-DICHLOROETHYLENE (ALL ISOMERS):

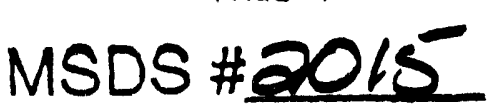

IRRITANT.

ACUTE EXPOSURE- DIRECT CONTACT MAY CAUSE IRRITATION. SKIN ABSORPTION MAY OCCUR DUE TO LIPID SOLUBILITY.

CHRONIC EXPOSURE- REPEATED OR PROLONGED CONTACT MAY CAUSE DERMATITIS.

FIRST AID- REMOVE CONTAMINATED CLOTHING AND SHOES IMMEDIATELY. WASH AFFECTED AREA WITH SOAP OR MILD DETERGENT AND LARGE AMOUNTS OF WATER UNTIL NO EVIDENCE OF CHEMICAL REMAINS (APPROXIMATELY 15-20 MINUTES). GET MEDICAL ATTENTION IMMEDIATELY.

EYE CONTACT:

1,2-DICHLOROETHYLENE (ALL ISOMERS):

IRRITANT.

ACUTE EXPOSURE - DIRECT CONTACT, OR THE VAPOR IN SUFFICIENT CONCENTRATION, MAY CAUSE IRRITATION. THE TRANS- ISOMER CAUSED BURNING OF THE EYES AT 2000 PPM. REVERSIBLE SUPERFICIAL CORNEAL TURBIDITY HAS BEEN REPORTED AS A SYSTEMIC EFFECT IN DOGS FOLLOWING INHALATION EXPOSURE.

CHRONIC EXPOSURE- REPEATED OR PROLONGED CONTACT WITH IRRITANTS MAY CAUSE CONJUNCTIVITIS.

FIRST AID- WASH EYES IMMEDIATELY WITH LARGE AMOUNTS OF WATER OR NORMAL SALINE, OCCASIONALLY LIFTING UPPER AND LOWER LIDS, UNTIL NO EVIDENCE OF CHEMICAL

REMAINS (APPROXIMATELY 15-20 MINUTES). GET MEDICAL ATTENTION IMMEDIATELY.

INGESTION:

1,2-DICHLOROETHYLENE (ALL ISOMERS):

NARCOTIC.

ACUTE EXPOSURE- DEPENDING ON EXPOSURE, SYMPTOMS MAY VARY FROM SLIGHT CENTRAL NERVOUS SYSTEM DEPRESSION TO DEEP NARCOSIS.

CHRONIC EXPOSURE- USED AS A LOW TEMPERATURE EXTRACTING AGENT FOR HEAT SENSITIVE SUBSTANCES SUCH AS CAFFEINE IN COFFEE, PERFUMES, AND OILS AND FATS FROM FISH AND MEAT. MICE EXPOSED TO $22 \mathrm{MG} / \mathrm{KG}$ OR $220 \mathrm{MG} / \mathrm{KG}$ OF TRANS- 1,2 DICHLOROETHYLENE BY GAVAGE FOR 14 CONSECUTIVE DAYS SHOWED A TREND TOWARD SUPPRESSION OF THE HUMORAL IMMUNE RESPONSE, BUT NO EFFECT ON THE CELL-MEDIATED IMMUNE RESPONSE.

FIRST AID- REMOVE BY GASTRIC LAVAGE OR EMESIS. MAINTAIN BLOOD PRESSURE AND AIRWAY. GIVE OXYGEN IF RESPIRATION IS DEPRESSED. DO NOT PERFORM GASTRIC LAVAGE OR EMESIS IF VICTIM IS UNCONSCIOUS. GET MEDICAL ATTENTION IMMEDIATELY (DREISBACH, HANDBOOK OF POISONING, IITH ED.). ADMINISTRATION OF GASTRIC LAVAGE OR OXYGEN SHOULD BE PERFORMED BY QUALIFIED MEDICAL PERSONNEL.

ANTIDOTE:

NO SPECIFIC ANTIDOTE. TREAT SYMPTOMATICALLY AND SUPPORTIVELY.

\section{REACTIVITY}

REACTIVITY:

MAY FORM EXPLOSIVE PEROXIDES IN AIR. U.VLES INHIBITED, GRADUAL DECOMPOSITION BY AIR, LIGHT, ULTAVIOLET LIGHT AND 
PAGE 5

MOISTURE MAY RELEASE CORROSIVE HYDROGEN CHLORIDE.

INCOMPATIBILITIES:

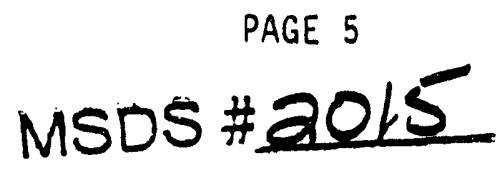

1,2-DICHLOROETHYLENE (ALL ISOMERS):

CAUSTIC ALKALIES (SOLID OR CONCENTRATED SOLUTIONS): MAY FORM EXPLOSIVE, SPONTANEOUSLY FLAMMABLE CHLOROACETYLENE.

COPPER OR COPPER ALLOYS: MAY FORM EXPLOSIVE, SPONTANEOUSLY FLAMMABLE CHLOROACETYLENE.

DIFLUOROMETHYLENE DIHYPOFLUORITE (WITH TRANS-ISOMER): VIOLENT EXPLOSION AT ROOM TEMPERATURE.

FREE RADICAL INITIATTOR: OXIDATION FORMS CORROSIVE CHLOROACETYL CHLORIDE VIA EPOXIDE INTERMEDIATES.

METAL (HOT): GRADUAL DECOMPOSITION WITH RELEASE OF CORROSIVE HYDROGEN CHLORIDE.

NITROGEN TETROXIDE: EXPLOSIVE, ESPECIALLY WHEN SHOCKED.

OZONE: FORM EXPLOSIVE PRODUCT.

PERCHLORYL FLUORIDE: EXPLOSIVE REACTION ON HEATING.

POTASSIUM HYDROXIDE (SOLID OR CONCENTRATED SOLUTION): MAY FORM EXPLOSIVE, SPONTANEOUSLY FLAMMABLE CHLOROACETYLENE.

PLASTICS, RUBBER AND COATINGS: MAY BE ATTACKED.

SODIUM: MAY FORM EXPLOSIVE, SPONTANEOUSLY FLAMMABLE CHLOROACETYLENE.

SODIUM HYDROXIDE (SOLID OR CONCENTRATED SOLUTION): MAY FORM EXPLOSIVE, SPONTANEOUSLY FLAMMABLE CHLOROACETYLENE.

SULFURIC ACID (CONCENTRATED): OXIDATION FORMS CORROSIVE CHLOROACETYL CHLORIDE VIA EPOXIDE INTERMEDIATES.

STRONG OXIDIZERS: VIGOROUS. REACTION OR POSSIBLE FIRE AND EXPLOSION HAZARD.

DECOMPOSITION:

THERMAL DECOMPOSITION PRODUCTS MAY INCLUDE HIGHLY TOXIC FUMES OF PHOSGENE, TOXIC AND CORROSIVE FUMES OF CHLORIDES, AND OXIDES OF CARBON.

POLYMERIZATION:

SLIGHTLY SUSCEPTIBLE TO POLYMERIZATION, BUT NOT LIKELY UNLESS THE MATERIAL BECOMES CONTAMINATED. BOTH ISOMERS DIMERIZE TO TETRACHLOROBUTENE IN THE PRESENCE OF ORGANIC PEROXIDES. THE POLYMERIZATION REACTION IS NOT VIGOROUS.

STORAGE AND DISPOSAL

STORAGE: PROTECT AGAINST PHYSICAL DAMAGE. OUTSIDE OR DETACHED STORAGE IS

PREFERABLE. INSIDE STORAGE SHOULD BE IN A STANDARD FLAMMABLE LIQUIDS STORAGE ROOM OR CABINET. SEPARATE FROM OXIDIZING MATERIALS (NFPA 49, HAZARDOUS CHEMICALS DATA, 1975).

AVOID CONTACT WITH HEAT, SPARKS, FLAMES, OR OTHER SOURCES OF IGNITION. VAPORS MAY BE EXPLOSIVE. AVOID OVERHEATING OF CONTAINERS; CONTAINERS MAY VIOLENTLY RUPTURE IN HEAT OF FIRE. AVOID CONTAMINATION OF WATER SOURCES. 
OCCUPATIONAL SPILL:

\section{PAGE 6

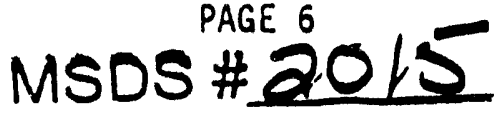

SHUT OFF IGNITION SOURCES. STOP LEAK IF YOU CAN DO IT WITHOUT RISK. USE WATER SPRAY TO REDUCE VAPORS. FOR SMALL SPILLS, TAKE UP WITH SAND OR OTHER ABSORBENT MATERIAL AND PLACE INTO CONTAINERS FOR LATER DISPOSAL. FOR LARGER SPILLS, DIKE FAR AHEAC OF SPILL FOR LATER DISPOSAL. NO SMOKING, FLAMES OR FLARES IN HAZARD AREA. KEEP UNNECESSARY PEOPLE AWAY; ISOLATE HAZARD AREA AND RESTRICT ENTRY.

VENTILATION:

PROVIDE LOCAL EXHAUST OR GENERAL DILUTION VENTILATION TO MEET PUBLISHED EXPOSURE LIMITS. VENTILATION EQUIPMENT MUST BE EXPLOSION-PROOF.

RESPIRATOR:

THE FOLLOWING RESPIRATORS AND MAXIMUM USE CONCENTRATIONS ARE RECOMMENDATIONS BY THE U.S. DEPARTMENT OF HEALTH AND HUMAN SERVICES, NIOSH POCKET GUIDE TO CHEMICAL HAZARDS; NIOSH CRITERIA DOCUMMENTS OR BY THE U.S. DEPARTMENT OF LABOR, 29 CFR 1910 SUBPART $Z$.

THE SPECIFIC RESPIRATOR SELECTED MUST BE BASED ON CONTAMINATION LEVELS FOUND IN THE WORK PLACE, MUST NOT EXC,EED THE WORKING LIMITS OF THE RESPIRATOR AND BE JOINTLY APPROVED BY THE NATI.ONAL INSTITUTE FOR OCCUPATIONAL SAFETY AND HEALTH AND THE MINE SAFETY AND HEALTH ADMINISTRATION (NIOSH-MSHA).

\section{1,2-DICHLOROETHYLENE (ALL ISOMERS):}

1000 PPM- ANY POWERED AIR-PURIFYING RESPIRATOR WITH ORGANIC. VAPOR CARTRIDGES.

ANY CHEMICAL CARTRIDGE RESPIRATOR WITH AN ORGANIC VAPOR CANISTER AND A FULL FACEPIECE.

4000 PPM- ANY SUPPLIED-AIR RESPIRATOR OPERATED IN A CONTINUOUS FLOW MODE. ANY AIR-PURIFYING FULL FACEPIECE RESPIRATOR (GAS MASK) WITH A CHIN-STYLE OR FRONT- OR BACK-MOUNTED ORGANIC VAPOR CANISTER. ANY SUPPLIED-AIR RESPIRATOR WITH A FULL FACEPIECE. ANY SELF-CONTAINED BREATHING APPARATUS WITH A FULL FACEPIECE.

ESCAPE- ANY AIR-PURIFYING FULL FACEPIECE RESPIRATOR (GAS MASK) WITH A CHIN-STYLE OR FRONT- OR BACK-MOUNTED ORGANIC VAPOR CANISTER. ANY APPROPRIATE ESCAPE-TYPE SELF-CONTAINED BREATHING APPARATUS.

FOR FIREFIGHTING AND OTHER IMMEDIATELY DANGEROUS TO LIFE OR HEALTH CONDITIONS:

ANY SELF-CONTAINED BREATHING APPARATUS THAT HAS A FULL FACEPIECE AND IS OPERATED IN A PRESSURE-DEMAND OR OTHER POSITIVE-PRESSURE MODE.

ANY SUPPLIED-AIR RESPIRATOR THAT HAS A FULL F'CEPIECE AND IS OPERATED IN A PRESSURE-DEMAND OR OTHER POSITIVE-PRESSURE MODE IN COMBINATION WITH AN AUXILIARY SELF-CONTAINED BREATHING APPARATUS OPERATED IN PRESSURE-DEMAND OR OTHER POSITIVE-PRESSURE MODE.

CLOTHING:

EMPLOYEE MUST WEAR APPROPRIATE PROTECTIVE (IMPERVIOUS) CLOTHING AND EQUIPMENT TO PREVENT REPEATED OR PROLONGED SKIN CONTACT WITH THIS SUBSTANCE. 
GLOVES:

EMPLOYEE MUST WEAR APPROPRIATE PROTECTIVE GLOVES TO PREVENT CONTACT WITH THIS SUBSTANCE.

EYE PROTECTION:

EMPLOYEE MUST WEAR SPLASH-PROOF OR DUST-RESISTANT SAFETY GOGGLES AND A FACESHIELD TO PREVENT CONTACT WITH THIS SUBSTANCE.

EMERGENCY WASH FACILITIES:

WHERE THERE IS ANY POSSIBILITY THAT AN EMPLOYEE'S EYES AND/OR SKIN MAY BE EXPOSED TO THIS SUBSTANCE. THE EMPLOYER SHOULD PROVIDE AN EYE WASH FOUNTAIN AND QUICK DRENCH SHOWER WITHIN THE IMMEDIATE WORK AREA FOR EMERGENCY USE.

OHSO5125

AUTHORIZED BY - OCCUPATIONAL HEALTH SERVICES, INC. CREATION DATE: $03 / 12 / 86$ REVISION DATE: $03 / 18 / 91$

$156-59-2$

CIS-1,2-DICHLOROETHYLENE

Copyright 1991 Occupational Health Services, Inc. All Rights Reserved. Licensed to: Hanford Environmental Health Foundation

To make uni imited paper copies for internal distribution and use only. 
PAGE 1

OHS23670

MATERIAL SAFETY DATA SHEET

OCCUPATIONAL HEALTH SERVICES, INC.

11 WEST 42ND STREET, 12TH FLOOR

NEW YORK, NEW YORK 10036

$1-800-445-M S D S(1-800-445-6737)$ OR

$1-212-789-3535$
FOR EMERGENCY SOURCE INFORMATION

CONTACT: $1-615-366-2000$

\section{MSDS\#2176}

SUBSTANCE IDENTIFICATION

SUBSTANCE: TRANS-1,2-OICHLOROETHYLENE

CAS-NUMBER $156-60-5$

TRADE NAMES/SYNONYMS:

-TRANS-ACETYLENE DICHLORIDE; TRANS-DICHLOROETHYLENE;

TRANS-1,2-DICHLOROETHENE; RCRA U079; OHS23670

CHEMICAL FAMILY:

HALOGEN COMPOUND, ALIPHATIC

MOLECULAR FORMULA: C2-H2-CL2

MOLECULAR WEIGHT: 96.94

CERCLA RATINGS (SCALE 0-3): HEALTH=2 FIRE $=3$ REACTIVITY $=2$ PERSISTENCE $=1$ NFPA RATINGS (SCALE 0-4): HEALTH=2 FIRE $=3$ REACTIVITY $=2$

COMPONENTS AND CONTAMINANTS

COMPONENT: TRANS-1,2-DICHLOROETHYLENE CAS\# 156-60-5

PERCENT: 100

OTHER CONTAMINANTS: NONE

EXPOSURE LIMITS:

TRANS-1,2-DICHLOROETHYLENE:

200 PPM OSHA TWA

200 PPM (790 MG/M3) ACGIH TWA

1000 POUNDS CERCLA SECTION 103 REPORTABLE QUANTITY

PHYSICAL DATA

DESCRIPTION: COLORLESS LIQUID WITH A PLEASANT ODOR.

BOILING POINT: $118 \mathrm{~F}(48 \mathrm{C})$ MELTING POINT: $-58 \mathrm{~F}(-50 \mathrm{C})$

SPECIFIC GRAVITY: 1.2565 VAPOR PRESSURE: 400 MM HG $\odot 87 \mathrm{~F}$

SOLUBILITY IN WATER: SLIGHTLY SOLUBLE ODOR THRESHOLD: NOT ESTABLISHED 
VAPOR DENSITY: 3.34

SOLVENT SOLUBILITY: ETHANOL, ETHYL ETHER

FIRE AND EXPLOSION DATA

FIRE AND EXPLOSION HAZARD:

DANGEROUS FIRE HAZARD WHEN EXPOSED TO HEAT OR FLAME.

VAPOR-AIR MIXTURES ARE EXPLOSIVE ABOVE FLASH POINT.

VAPORS ARE HEAVIER THAN AIR AND MAY TRAVEL A CONSIDERABLE DISTANCE TO A SOURCE OF IGNITION AND FLASH BACK.

FLASH POINT: $36 \mathrm{~F}(2 \mathrm{C})$ (CC) UPPER EXPLOSIVE LIMIT: $12.8 \%$

LOWER EXPLOSIVE LIMIT: $9.7 \%$ AUTOIGNITION TEMP.: $860 \mathrm{~F}(460 \mathrm{C})$

FLAMMABILITY CLASS(OSHA): IB

FIREFIGHTING MEDIA:

DRY CHEMICAL, CARBON DIOXIDE, WATER SPRAY OR REGULAR FOAM

(1990 EMERGENCY RESPONSE GUIDEBOOK, DOT P 5800.5).

FOR LARGER FIRES, USE WATER SPRAY, FOG OR REGULAR FOAM

(1990 EMERGENCY RESPONSE GUIDEBOOK, DOT P 5800.5).

FIREF IGHTING :

MOVE CONTAINER FROM FIRE AREA IF YOU CAN DO IT WITHOUT RISK. APPLY COOLING WATER TO SIDES OF CONTAINERS THAT ARE EXPOSED TO FLAMES UNTIL WELL AFTER FIRE IS OUT. STAY AWAY FROM ENDS OF TANKS. FOR MASSIVE FIRE IN CARGO AREA, USE UNMANNED HOSE HOLDER OR MONITOR NOZZLES; IF THIS IS IMPOSSIBLE, WITHDRAW FROM AREA AND LET FIRE BURN. WITHDRAW IMMEDIATELY IN CASE OF RISING SOUND FROM VENTING SAFETY DEVICE OR ANY DISCOLORATION OF TANK DUE TO FIRE. ISOLATE FOR $1 / 2$ MILE IN ALL DIRECTIONS IF TANK, RAIL CAR OR TANK TRUCK IS INVOLVED IN FIRE (1990 EMERGENCY RESPONSE GUIDEBOOK, DOT P 5800.5, GUIDE PAGE 27).

EXTINGUISH ONLY IF FLOW CAN BE STOPPED; USE FLOODING AMOUNTS OF WATER AS A FOG, SOLID STREAMS MAY BE INEFFECTIVE. COOL CONTAINERS WITH FLOODING AMOUNTS OF WATER, APPLY FROM AS FAR A DISTANCE AS POSSIBLE. AVOID BREATHING VAPORS, KEEP UPWIND.

TRANSPORTATION DATA

DEPARTMENT OF TRANSPORTATION HAZARD CLASSIFICATION 49 CFR 172.101:

FLAMMABLE LIQUID

DEPARTMENT OF TRANSPORTATION LABELING REQUIREMENTS 49 CFR 172.101 AND SUBPART E:

FLAMMABLE LIQUID

DEPARTMENT OF TRANSPORTATION PACKAGING REQUIREMENTS: 49 CFR 173.119 
TRANS-1, 2-DICHLOROETHYLENE:

$4800 \mathrm{MG} / \mathrm{M} 3 / 10$ MINUTES INHALATION-HUMAN TCLO; $43000 \mathrm{MG} / \mathrm{M} 3 / 6$ HOURS

INHALATION-CAT LCLO; 75000 MG/M3/2 HOURS INHALATION-MOUSE LCLO; $2122 \mathrm{MG} / \mathrm{KG}$ ORAL-MOUSE LD50; 4019 INTRAPERITONEAL-MOUSE LD50; 7536 MG/KG

INTRAPERITONEAL-RAT LD50; MUTAGENIC DATA (RTECS); CARCINOGEN STATUS: NONE.

TRANS-1,2-DICHLOROETHYLENE IS A CENTRAL NERVOUS SYSTEM DEPRESSANT AND A SKIN, EYE, AND MUCOUS MEMBRANE IRRITANT. STIMULANTS SUCH AS EPINEPHRINE AND EPHEDRINE' MAY ENHANCE THE TOXICITY OF SOME HALOGENATED HYDROCARBONS. PFRSONS WITH CHRONIC RESPIRATORY DISEASE MAY BE AT AN INCREASED RISK FROM EXPCSURE.

HEALTH EFFECTS AND FIRST AID

INHALATION:

1,2-DICHLOROETHYLENE (ALL ISOMERS):

IRRITANT/NARCOTIC. 4000 PPM IMMEDIATELY DANGEROUS TO LIFE OR HEALTH.

ACUTE EXPOSURE - VAPOR EXPOSURE MAY CAUSE MUCOUS MEMBRANE IRRITATION, NAUSEA, VOMITING, DIZZINESS, WEAKNESS, TREMOR, AND EPIGASTRIC CRAMPS. HIGHER

LEVELS MAY CAUSE CENTRAL NERVOUS SYSTEM DEPRESSION RANGING FROM OROWSINESS TO UNCONSCIOUSNESS. THE CIS- AND TRANS- ISOMERS TOGETHER HAVE BEEN USED AS AN ANESTHETIC IN MAN. A HUMAN DEATH HAS BEEN REPORTED FROM INDUSTRIAL EXPOSURE. AN 8 HOUR EXPOSURE TO THE TRANS - ISOMER AT 200 PPM LOWERED THE LEUKOCYTE COUNT IN RATS; 1000 PPM CAUSED A FALL IN THE BLOOD SERUM ALBUMIN, UREA NITROGEN, ALKALINE PHOSPHATASE ACTIVITY, AND THE NUMBER OF ERYTHROCYTES. NARCOSIS WAS NOT PRODUCED AT THESE LEVELS. 3000 PPM PRODUCED FIBROUS SWELLING OF THE CARDIAC MUSCLE AND HYPEREMIA WHICH PERSISTED FOR 14 HOURS AFTER EXPOSURE. THE CIS. ISOMER DID NOT ANESTHETIZE RATS IN 4 HOURS AT 8000 PPM, BUT AT 16,000 PPM THEY WERE ANESTHETIZED IN 8 MINUTES AND KILLED IN 4 HOURS. REVERSIBLE SUPERFICIAL. CORNEAL TURBIDITY HAS BEEN OBSERVED IN SOME ANESTHETIZED DOGS.

CHRONIC EXPOSURE- VARIATIONS IN DATA EXIST ON THE CHRONIC TOXICITY OF THE CIS- AND TRANS- ISOMERS. RATS EXPOSED TO 200 P DM OF THE TRANS- ISOMER FOR 8 HOURS/DAY, 5 DAYS/WEEK FOR 16 WEEKS SHOWED HISTOLOGICAL EVIDENCE OF SLIGHT TO SEVERE FATTY DEGENERATION OF LIVER LOBULES AND KUPFFER CELLS, MARKED PULMONARY HYPEREMIA, ALVEOLAR SEPTAL DISTENSION AND FIBROUS SWELLING OF THE CAROIAC MUSCLE. SIMILAR EXPOSURES WITH RATS, GUINEA PIGS, RABBITS AND DOGS EXPOSED TO 500 PPM OR 1000 PPM 7 HOURS/DAY, 5 DAYS/WEEK FOR 6 MONTHS TO A MIXTURE OF 60\% CIS- AND 40\% TRANS- ISOMERS RESULTED IN NO ADVERSE EFFECTS DETECTED. CATS AND RABBITS WERE REPEATEDLY EXPOSED TO VAPOR CONCENTRATIONS OF $0.16-0.19 \%$ IN AIR. THE CIS- ISOMER CAUSED ANOREXIA, DECREASED BODY WEIGHT AND PATHOLOGICAL CHANGES IN THE LUNGS, LIVER, AND KIDNEYS. THE TRANS- ISOMER CAUSED ANOREXIA AND SOME RESPIRATORY IRRITATION, BUT NO HISTOPATHOLOGICAL CHANGES IN ORGANS.

FIRST AID- REMOVE FROM EXPOSURE AREA TO FRESH AIR IMMEDIATELY. IF BREATHING HAS STOPPED, PERFORM ARTIFICIAL RESPIRATION. KEEP PERSON WARM AND AT REST. TREAT SYMPTOMATICALLY AND SUPPORTIVELY. GET MEDICAL ATTENTION IMMEDIATELY. 
PAGE 4

SKIN CONTACT:

1,2-DICHLOROETHYLENE (ALL ISOMERS):

RRITANT.

ACUTE EXPOSURE- DIRECT CONTACT MAY CAUSE IRRITATION. SKIN ABSORPTION MAY OCCUR DUE TO LIPID SOLUBILITY.

CHRONIC EXPOSURE- REPEATED OR PROLONGED CONTACT MAY CAUSE DERMATITIS.

FIRST AID- REMOVE CONTAMINATED CLOTHING AND SHOES IMMEDIATELY. WASH AFFECTED AREA WITH SOAP OR MILD DETERGENT AND LARGE AMOUNTS OF WATER UNTIL NO EVIDENCE OF CHEMICAL REMAINS (APPROXIMATELY 15-20 MINUTES). GET MEDICAL ATTENTION IMMEDIATELY.

EYE CONTACT:

1,2-DICHLOROETHYLENE (ALL ISOMERS):

IRRITANT.

ACUTE EXPOSURE- DIRECT CONTACT, OR THE VAPOR IN SUFFICIENT CONCENTRATION, MAY CAUSE IRRITATION. THE TRANS - ISOMER CAUSED BURNING OF THE EYES AT 2000 PPM. REVERSIBLE SUPERFICIAL CORNEAL TURBIDITY HAS BEEN REPORTED AS A SYSTEMIC EFFECT IN DOGS FOLLOWING INHALATION EXPOSURE.

CHRONIC EXPOSURE- REPEATED OR PROLONGED CONTACT WITH IRRITANTS MAY CAUSE CONJUNCTIVITIS.

FIRST AID- WASH EYES IMMEDIATELY WITH LARGE AMOUNTS OF WATER OR NORMAL SALINE, OCCASIONALLY LIFTING UPPER AND LOWER LIDS, UNTIL NO EVIDENCE OF CHEMICAL

REMAINS (APPROXIMATELY 15-20 MINUTES). GET MEDICAL ATTENTION IMMEDIATELY.

INGESTION:

1,2-DICHLOROETHYLENE (ALL ISOMERS):

NARCOTIC.

ACUTE EXPOSURE- DEPENDING ON EXPOSURE, SYMPTOMS MAY VARY FROM SLIGHT CENTRAL NERVOUS SYSTEM DEPRESSION TO DEEP NARCOSIS.

CHRONIC EXPOSURE- USED AS A LOW TEMPERATURE EXTRACTING AGENT FOR HEAT SENSITIVE SUBSTANCES SUCH AS CAFFEINE IN COFFEE, PERFUMES, AND OILS AND FATS FROM FISH AND MEAT. MICE EXPOSED TO $22 \mathrm{MG} / \mathrm{KG}$ OR $220 \mathrm{MG} / \mathrm{KG}$ OF TRANS-1,2 DICHLOROETHYLENE BY GAVAGE FOR 14 CONSECUTIVE DAYS SHOWED A TREND TOWARD SUPPRESSION OF THE HUMORAL IMMUNE RESPONSE, BUT NO EFFECT ON THE CELL-MEDIATED IMMUNE RESPONSE.

FIRST AID- REMOVE BY GASTRIC LAVAGE OR EMESIS. MAINTAIN BLOOD PRESSURE AND AIRWAY. GIVE OXYGEN IF RESPIRATION IS DEPRESSED. DO NOT PERFORM GASTRIC LAVAGE OR EMESIS IF VICTIM IS UNCONSCIOUS. GET MEDICAL ATTENTION IMMEDIATELY (DREISBACH, HANDBOOK OF POISONING, IITH ED.). ADMINISTRATION OF GASTRIC LAVAGE OR OXYGEN SHOULD BE PERFORMED BY QUALIFIED MEDICAL PERSONNEL.

ANTIDOTE:

NO SPECIFIC ANTIDOTE. TREAT SYMPTOMATICALLY AND SUPPORTIVELY.

REACTIVITY

REACTIVITY:

MAY FORM EXPLOSIVE PEROXIDES IN AIR.

UNLESS INHIBITED, GRADUAL DECOMPOSITION BY AIR, LIGHT, ULTAVIOLET LIGHT AND 
PAGE 5

MOISTURE MAY RELEASE CORROSIVE HYDROGEN CHLORIDE.

INCOMPATIBILITIES:

MSDS\#2176

1,2-OICHLOROETHYLENE (ALL ISOMERS):

CAUSTIC ALKALIES (SOLID OR CONCENTRATED SOLUTIONS): MAY FORM EXPLOSIVE, SPONTANEOUSLY FLAMMABLE CHLOROACETYLENE.

COPPER OR COPPER ALLOYS: MAY FORM EXPLOSIVE, SPONTANEOUSLY FLAMMABLE CHLOROACETYLENE.

DIFLUOROMETHYLENE DIHYPOFLUORITE (WITH TRANS-ISOMER): VIOLENT EXPLOSION AT ROOM TEMPERATURE.

FREE RADICAL INITIATOR: OXIDATION FORMS CORROSIVE CHLOROACETYL CHLORIDE VIA EPOXIDE INTERMEDIATES.

METAL (HOT): GRADUAL DECOMPOSITION WITH RELEASE OF CORROSIVE HYOROGEN CHLORIDE.

NITROGEN TËTROXIDE: EXPLOSIVE, ESPECIALLY WHEN SHOCKED.

OZONE: FORM EXPLOSIVE PROOUCT'

PERCHLORYL FLUORIDE: EXPLOSIVE REACTION ON HEATING.

POTASSIUM HYDROXIDE (SOLID OR CONCENTRATED SOLUTION): MAY FORM EXPLOSIVE, SPONTANEOUSLY. FLAMMABLE CHLOROACETYLENE.

PLASTICS, RUBBER AND COATINGS: MAY BE ATTACKED.

SODIUM: MAY FORM EXPLOSIVE, SPONTANEOUSLY FLAMMABLE CHLOROACETYLENE.

SODIUM HYDROXIDE (SOLID OR CONCENTRATED SOLUTION): MAY FORM EXPLOSIVE, SPONTANEOUSLY FLAMMABLE CHLOROACETYLENE.

SULFURIC ACID (CONCENTRATED): OXIDATION FORMS CORROSIVE CHLOROACETYL CHLORIDE VIA EPOXIDE INTERMEDIATES.

STRONG OXIDIZERS: VIGOROUS REACTION OR POSSIBLE FIRE AND EXPLOSION HAZARD.

DECOMPOSITION:

THERMAL DECOMPOSITION PRODUCTS MAY INCLUDE HIGHLY TOXIC FUMES OF PHOSGENE, TOXIC AND CORROSIVE FUMES OF CHLORIDES, AND OXIDES OF CARBON.

POLYMERIZATION:

SLIGHTLY SUSCEPTIBLE TO POLYMERIZATION, BUT NOT LIKELY UNLESS THE MATERIAL BECOMES CONTAMINATED. BOTH ISOMERS DIMERIZE TO TETRACHLOROBUTENE IN THE PRESENCE OF ORGANIC PEROXIDES. THE POLYMERIZATION REACTION IS NOT VIGOROUS.

STORAGE AND DISPOSAL

STORAGE: PROTECT AGAINST PHYSICAL DAMAGE. OUTSIDE OR DETACHED STORAGE IS

PREFERABLE. INSIDE STORAGE SHOULD BE IN A STANDARD FLAMMABLE LIQUIDS STORAGE ROOM OR CABINET. SEPARATE FROM OXIDIZING MATERIALS (NFPA 49, HAZARDOUS CHEMICALS DATA, 1975).

CONDITIONS TO AVOID

AVOID CONTACT WITH HEAT, SPARKS, FLAMES OR OTHER IGNITION SOURCES. VAPORS MAY BE EXPLOSIVE. MATERIAL ! " CORROSIVE; AVOID CONTACT WITH SKIN OR EYES. DO NOT ALLOW CONTAMINATION OF WATER SOURCES. 
PAGE 6

OCCUPATIONAL SPILL:

SHUT OFF IGNITION SOURCES. DO NOT TOUCH SPILLED MATERIAL. STOP LEAK IF YOU CAN DO IT WITHOUT RISK. USE WATER SPRAY TO REDUCE VAPORS. DO NOT GET WATER INSIDE CONTAINER. FOR SMALL SPILLS, TAKE UP WITH SAND OR OTHER ABSORBENT MATERIAL AND PLACE INTO CONTAINERS FOR LATER DISPOSAL. FOR LARGER SPILLS, DIKE FAR AHEAD OF SPILL FOR LATER DISPOSAL. NO SMOKIIVG, FLAMES OR FLARES IN HAZARD AREA. KEEP UNNECESSARY PEOPLE AWAY; ISOLATE HAZARO AREA AND DENY ENTRY.

REPORTABLE QUANTITY (RQ): 1000 POUNDS

THE SUPERFUND AMENDMENTS AND REAUTHORIZATION ACT (SARA) SECTION 304 REQUIRES

THAT A RELEASE EQUAL TO OR GREATER THAN THE REPORTABLE QUANTITY FOR THIS SUBSTANCE BE IMMEDIATELY REPORTED TO THE LOCAL EMERGENCY PLANNING COMMITTEE AND THE STATE EMERGENCY RESPONSE COMMISSION (40 CFR 355.40). IF THE RELEASE OF THIS SUBSTANCE IS REPORTABLE UNDER CERCLA SECTION 103, THE NATIONAL RESPONSE CENTER MUST BE NOTIFIED IMMEDIATELY AT (800) 424-8802 OR (202) 426-26.75 IN THE METROPOLITAN WASHINGTON, D.C. AREA (40 CFR 302.6).

VENTILATION:

PROVIDE LOCAL EXHAUST OR GENERAL DILUTION VENTILATION TO MEET PUBLISHED EXPOSURE LIMITS. VENTILATION EQUIPMENT MUST BE EXPLOSION-PROOF.

RESPIRATOR:

THE FOLLOWING RESPIRATORS AND MAXIMUM USE CONCENTRATIONS ARE RECOMMENDATIONS BY THE U.S. DEPARTMENT OF HEALTH AND HUMAN SERVICES, NIOSH POCKET GUIDE TO CHEMICAL HAZARDS; NIOSH CRITERIA DOCUMENTS OR BY THE U.S. DEPARTMENT OF LABOR; 29 CFR 1910 SUBPART $Z$.

THE SPECIFIC RESPIRATOR SELECTED MUST BE BASED ON CONTAMINATION LEVELS FOUND IN THE WORK PLACE, MUST NOT EXCEED THE WORKING LIMITS OF THE RESPIRATOR AND BE JOINTLY APPROVED BY THE NATIONAL INSTITUTE FOR OCCUPATIONAL SAFETY AND HEALTH AND THE MINE SAFETY AND HEALTH ADMINISTRATION (NIOSH-MSHA).

1,2-OICHLOROETHYLENE (ALL ISOMERS):

1000 PPM- ANY POWERED AIR-PUR IFYING RESPIRATOR WITH ORGANIC VAPOR CARTRIDGES.

ANY CHEMICAL CARTRIDGE RESPIRATOR WITH AN ORGANIC VAPOR CANISTER AND A FULL FACEPIECE.

4000 PPM- ANY SUPPLIED-AIR RESPIRATOR OPERATED IN A CONTINUOUS FLOW MODE. ANY AIR-PURIFYING FULL FACEPIECE RESPIRATOR (GAS MASK) WITH A CHIN-STYLE OR FRONT- OR BACK-MOUNTED ORGANIC VAPOR CANISTER. ANY SUPPLIED-AIR RESPIRATOR WITH A FULL FACEPIECE.

ANY SELF-CONTAINED BREATHING APPARATUS WITH A FULL FACEPIECE.

ESCAPE- ANY AIR-PURIFYING FULL FACEPIECE RESPIRATOR (GAS MASK) WITH A CHIN-STYLE OR FRONT- OR BACK-MOUNTED ORGANIC VAPOR CANISTER. ANY APPROPRIATE ESCAPE-TYPE SELF-CONTAINED BREATHING APPARATUS.

FOR FIREFIGHTING AND OTHER IMMEDIATELY DANGEROUS TO LIFE OR HEALTH CONDITIONS:

ANY SELF-CONTAINED BREATHING APPARATUS THAT HAS A FULL FACEPIECE AND IS OPERATED IN A PRESSURE-DEMAND OR OTHER POSITIVE-PRESSURE MODE. 


\section{MSDS\#2176 PAGE 7}

ANY SUPPLIED-AIR RESPIRATOR THAT HAS A FULL FACEPIECE AND IS OPERATED IN A PRESSURE-DEMAND OR OTHER POSITIVE-PRESSURE MODE IN COMBINATION WITH AN AUXILIARY SELF-CONTAINED BREATHING APPARATUS OPERATED IN PRESSURE-DEMAND OR OTHER POSITIVE-PRESSURE MODE.

CLOTHING :

EMPLOYEE MUST WEAR APPROPRIATE PROTECTIVE (IMPERVIOUS) CLOTHING AND EQUIPMENT TO PREVENT REPEATED OR PROLONGED SKIN CONTACT WITH THIS SUBSTANCE.

GLOVES:

EMPLOYEE MUST WEAR APPROPRIATE PROTECTIVE GLOVES TO PREVENT CONTACT WITH THIS SUBSTANCE.

EYE PROTECTION:

EMPLOYEE MUST WEAR SPLASH-PROOF OR DUST-RESISTANT SAFETY GOGGLES AND A FACESHIELD TO PREVENT CONTACT WITH THIS SUBSTANCE.

EMERGENCY WASH FACILITIES:

WHERE THERE IS ANY POSSIBILITY THAT AN EMPLOYEE'S EYES AND\%OR SKIN MAY BE EXPOSED TO THIS SUBSTANCE, THE EMPLOYER SHOULD PROVIDE AN EYE WASH FOUNTAIN AND QUICK DRENCH SHOWER WITHIN THE IMMEDIATE WORK AREA FOR EMERGENCY USE.

OHS23670

AUTHORIZED BY - OCCUPATIONAL HEALTH SERVICES, INC.

$150-60-5$

TRANS-1,2-OICHLOROETHYLENE

Copyright 1991 Occupational Health Services, Inc. All Rights Reserved. Licensed to: Hanford Environmental ilealth Foundation

To make uni imited paper copies for internal distribution and use only. 
OCCUPATIONAL HEALTH SERVICES, INC.

11 WEST 42ND STREET, 12TH FLOOR

NEW YORK, NEW YORK 10036

$1-800-445$-MSDS $(1-800-445-6737)$ OR

$1-212-789-3535$
FOR EMERGENCY SOURCE INFORMATION

CONTACT: 1-615-366-2000

\section{SUBSTANCE IDENTIFICATION}

\section{MSDS\#2022}

CAS-NUMBER 141-78-6

SUBSTANCE: ETHYL ACETATE

TRADE NAMES/SYNONYMS:

ACETIC ACID ETHYL ESTER; ACETIC ETHER; ACETIDIN; ACETOXYETHANE;

ETHYL ETHANOATE; VINEGAR NAPHTHA; ACETIC ESTER; RCRA UI12; STCC 4909160;

UN 1173; C4H802; OHSO8750

CHEMICAL FAMILY:

ESTER, CARBOXYLIC, ALIPHATIC

MOLECULAR FORMULA: C-H3-C-O2-C2-H5

MOLECULAR WEIGHT: 88.11

CERCLA RATINGS (SCALE 0-3): HEALTH=3 FIRE $=3$ REACTIVITY $=0$ PERSISTENCE $=0$ NFPA RATINGS (SCALE 0-4): HEALTH=1 FIRE $=3$ REACTIVITY $=0$

COMPONENTS AND CONTAMINANTS

COMPONENT: ETHYL ACETATE

$$
\text { CAS\# 141-78-6 }
$$

PERCENT: 100.0

OTHER CONTAMINANTS: NONE

\section{EXPOSURE LIMITS:}

ETHYL ACETATE:

400 PPM (1440 MG/M3) OSHA TWA

400 PPM $1440 \mathrm{MG} / \mathrm{M3}$ ACGIH TWA

$400 \mathrm{PPM} 1440 \mathrm{MG} / \mathrm{M3}$ NIOSH RECOMMENDED TWA

400 PPM I $440 \mathrm{MG} / \mathrm{M3}$ DFG MAK TWA;

$800 \mathrm{PPM}(2880 \mathrm{MG} / \mathrm{M3})$ DFG MAK 5 MINUTE PEAK, MOMENTARY VALUE, 8 TIMES/SHIFT

MEASUREMENT METHOD: CHARCOAL TUBE; CARBON DISULFIDE; GAS CHROMATOGRAPHY WITH FLAME IONIZATION DETECTION; (NIOSH VOL. II(2) \# S49).

5000 POUNDS CERCLA SECTION 103 REPORTABLE QUANTITY

\section{PHYSICAL DATA}

DESCRIPTION: TRANSPARENT, COLORLESS, VOLATILE LIQUID HAVING A FRAGRANT, 
SLIGHTLY FRUITY ODOR AND A PECULIAR, FRUITY, BURNING TASTE. BOILING POINT: $171 \mathrm{~F}(77 \mathrm{C})$ MELTING POINT: $-119 \mathrm{~F}(-84 \mathrm{C})$ SPECIFIC GRAVITY: 0.9003 VOLATILITY: $100 \%$ VAPOR PRESSURE: 73 MMHG \& $20 \mathrm{C}$ EVAPORATION RATE: (BUTYL ACETATE=1) $6.2 \quad$ PH: NEUTRAL

SOLUBILITY IN WATER: $8.7 \%$ ODOR THRESHOLD: 50 PPM VAPOR DENSITY: 3.04

SOLVENT SOLUBILITY: SOLUBLE IN ALCOHOL, BENZENE, ETHER, ACETONE, AND CHLOROFORM.

\section{FIRE AND EXPLOSION DATA}

FIRE AND EXPLOSION HAZARD:

DANGEROUS FIRE HAZARO WHEN EXPOSED TO HEAT OR FLAME.

VAPORS ARE HEAVIER THAN AIR AND MAY TRAVEL A CONSIDERABIE DISTANCE TO A SOURCE OF IGNITION AND FLASH BACK.

VAPOR-AIR MIXTURES ARE EXPLOSIVE ABOVE FLASH POINT.

FLASH POINT: $24 \mathrm{~F}(-4 \mathrm{C})(\mathrm{CC})$ UPPER EXPLOSIVE LIMIT: $11.5 \%$

LOWER EXPLOSIVE LIMIT: $2.0 \%$ AUTOIGNITION TEMP.: $800 \mathrm{~F}(426 \mathrm{C})$

FLAMMABILITY CLASS(OSHA): IB

FIREFIGHTING MEDIA:

DRY CHEMICAL, CARBON DIOXIDE, WATER SPRAY OR ALCOHOL-RESISTANT FOAM

(1990 EMERGENCY RESPONSE GUIDEBOOK, DOT P 5800.5).

FOR LARGER FIRES, USE WATER SPRAY, FOG OR ALCOHOL-RESISTANT FOAM (1990 EMERGENCY RESPONSE GUIDEBOOK, DOT $P$ 5800.5).

ALCOHOL FOAM

(NFPA 325M, FIRE HAZARD PROPERTIES OF FLAMMABLE LIQUIDS, GASES, AND VOLATILE SOLIOS, 1984).

FIREFIGHTING:

MOVE CONTAINER FROM FIRE AREA IF YOU CAN DO IT WITHOUT RISK. APPLY COOLING WATER TO SIDES OF CONTAINERS THAT ARE EXPOSED TO FLAMES UNTIL WELL AFTER FIRE IS OUT. STAY AWAY FROM ENDS OF TANKS. FOR MASSIVE FIRE IN CARGO AREA, USE UNMANNED HOSE HOLDER OR MONITOR NOZZLES; IF THIS IS IMPOSSIBLE, WITHDRAW FROM AREA AND LET FIRE BURN. WITHDRAW IMMED IATELY IN CASE OF RISING SOUND FROM VENTING SAFETY DEVICE OR ANY DISCOLORATION OF TANK DUE TO FIRE. ISOLATE FOR 1/2 MILE IN ALL DIRECTIONS IF TANK, RAIL CAR OR TANK TRUCK IS INVOLVED IN FIRE (1990 EMERGENCY RESPONSE GUIDEBOOK, DOT P 5800.5, GUIDE PAGE 26).

EXTINGUISH ONLY IF FLOW CAN BE STOPPED; USE WATER IN FLOODING AMOUNTS AS FOG, SOLID STREAMS MAY NOT BE EFFECTIVE. COOL CONTAINERS WITH FLOODING AMOUNTS OF 
PAGE 3

WATER, APPLY FROM AS FAR A DISTANCE AS POSSIBLE. AVOID BREATHING VAPORS, KEEP UPWIND.

WATER MAY BE INEFFECTIVE (NFPA 325M, FIRE HAZARD PROPERTIES OF FLAMMABLE LIQUIDS, GASES, AND VOLATILE SOLIDS, 1984)

TRANSPORTATION DATA

DEPARTMENT OF TRANSPORTATION HAZARD CLASSIFICATION 49 CFR 172.101: FLAMMABLE LIQUID

DEPARTMENT OF TRANSPORTATION LABELING REQUIREMENTS 49 CFR 172.101 AND SUBPART E:

FLAMMABLE LIQUID

DEPARTMENT OF TRANSPORTATION PACKAGING REQUIREMENTS: 49 CFR 173.119

EXCEPTIONS: 49 CFR 173.118

\section{TOXICITY}

ETHYL ACETATE:

IRRITATION DATA: 400 PPM EYE-HUMAN.

TOXICITY DATA: 400 PPM INHALATION-HUMAN TCLO; 1600 PPM/8 HOURS INHALATION-RAT LC5O; 45 GM/M3/2 HOURS INHALATION-MOUSE LC50; $77 \mathrm{MG} / \mathrm{M} 3 / 1$ HOUR INHALATION-GUINEA PIG LCLO; 61 GM/M3 INHALATION-CAT LCLO; $5620 \mathrm{MG} / \mathrm{KG}$ ORAL-RAT LD50; 4100 MG/KG ORAL-MOUSE LD50; $4935 \mathrm{MG} / \mathrm{KG}$ ORAL-RABBIT LD50; $5500 \mathrm{MG} / \mathrm{KG}$ ORAL-GUINEA PIG LD50; $5000 \mathrm{MG} / \mathrm{KG}$ SUBCUTANEOUS-RAT LDLO; $3000 \mathrm{MG} / \mathrm{KG}$ SUBCUTANEOUS-GUINEA PIG LD50; $3000 \mathrm{MG} / \mathrm{KG}$ SUBCUTANEOUS-CAT LD50; $709 \mathrm{MG} / \mathrm{KG}$ INTRAPERITONEAL-MOUSE LD50; MUTAGENIC DATA (RTECS).

CARCINOGEN STATUS: NONE.

LOCAL EFFECTS: IRRITANT- INHALATION, SKIN, EYE.

ACUTE TOXICITY LEVEL: TOXIC BY INHALATION; SLIGHTLY TOXIC BY INGESTION.

TARGET EFFECTS: CENTRAL NERVOUS SYSTEM DEPRESSANT. POISONING MAY ALSO AFFECT THE LIVER AND KIDNEYS.

AT INCREASED RISK FROM EXPOSURE: PERSONS WITH CHRONIC RESPIRATORY DISEASE, SKIN DISEASE OR ANEMIA.

HEALTH EFFECTS AND FIRST AID

INHALATION:

ETHYL ACETATE:

IRRITANT/NARCOTIC/TOXIC. 10,000 PPM IMMEDIATELY DANGEROUS TO LIFE OR HEALTH. ACUTE EXPOSURE - INHALATION OF 400 PPM FOR 3-5 MINUTES HAS CAUSED RESPIRATORY TRACT IRRITATION IN HUMANS. LOW VAPOR CONCENTRATIONS MAY ALSO CAUSE HEADACHE, COUGHING, DIZZINESS, DROWSINESS, AND SHORTNESS OF BREATH. HIGH CONCENTRATIONS MAY CAUSE NARCOTIC EFFECTS WITH ANESTHESIA AND UNCONSC IOUSNESS AND RENAL AND HEPATIC DAMAGE. PATHOLOGIC FINDINGS HAVE INCLUOED MARKED HYPEREMIA OF THE RESPIRATORY TRACT, PULMONARY EDEMA, HEMORRHAGIC GASTRITIS, AND HYPEREMIA OF THE SPLEEN AND KIDNEYS.

CHRONIC EXPOSURE- NO ADVERSE SYMPTOMS WERE OBSERVED IN WORKERS EXPOSED TO 375-1500 PPM FOR SEVERAL MONTHS. ANIMAL STUDIES INDICATE THAT 4450 PPM 
PAGE 4

FOR 1 HOUR DAILY FOR 40 DAYS CAUSED SECONDARY ANEMIA, LEUKOCYTOSIS, AND LIVER AND KIDNEY DAMAGE. IN RARE INSTANCES, REPEATED EXPOSURE MAY RESULT IN SENSITIZATION WITH MUCOUS MEMBRANE IRRITATION AND ECZEMATOUS ERUPTIONS.

FIRST AID- REMOVE FROM EXPOSURE AREA TO FRESH AIR IMMEDIATELY. IF BREATHING HAS STOPPED, PERFORM ARTIFICIAL RESPIRATION. KEEP PERSON WARM AND AT REST. TREAT SYMPTOMATICALLY AND SUPPORTIVELY. GET MEDICAL ATTENTION IMMEDIATELY.

SKIN CONTACT:

ETHYL ACETATE:

MSDS \#2027

IRRITANT

ACUTE EXPOSURE- DIRECT CONTACT WITH THE LIQUID MAY CAUSE IRRITATION WITH REDNESS AND DEFATTING ACTION ON THE SKIN.

CHRONIC EXPOSURE- REPEATED OR PROLONGED EXPOSURE MAY CAUSE DEFATTING DERMATITIS. IN RARE INSTANCES, REPEATED EXPOSURE MAY RESULT IN SENSITIZATION WITH ECZEMATOUS ERUPTIONS.

FIRST AID- REMOVE CONTAMINATED CLOTHING AND SHOES IMMEDIATELY. WASH AFFECTED AREA WITH SOAP OR MILD DETERGENT AND LARGE AMOUNTS OF WATER UNTIL NO EVIDENCE OF CHEMICAL REMAINS (APPROXIMATELY 15-20 MINUTES). GET MEDICAL ATTENTION IMMEDIATELY.

EYE CONTACT:

ETHYL ACETATE:

IRRITANT.

ACUTE EXPOSURE- DIRECT CONTACT WITH THE LIQUID MAY CAUSE IRRITATION, WITH REDNESS, PAIN, AND LACRIMATION. EXPOSURE TO 400 PPM MAY CAUSE A SENSATION OF IRRITATION IN HUMANS. APPLICATION OF 2 OROPS TO RABBIT CORNEAS, FOLLOWED 2 MINUTES LATER BY RINSING WITH WATER, CAUSED IMMEDIATE FINE OPTICAL IRREGULARITY OF THE CORNEAL EPITHELIUM, WHICH RETURNED TO NORMAL IN 2 DAYS.

CHRONIC EXPOSURE- REPEATED OR PROLONGED EXPOSURE MAY CAUSE CONJUNCTIVITIS AND CORNEA CLOUDING. RABBITS EXPOSED TO THE VAPOR AT LEVELS WHICH WOULD BE SCARCELY TOLERABLE TO HUMANS CAUSED NO CORNEAL DAMAGE DESPITE BEING EXPOSED FOR 8 HOURS/DAY FOR 5 DAYS/WEEK FOR UP TO 7 WEEKS.

FIRST AID- WASH EYES IMMEDIATELY WITH LARGE AMOUNTS OF WATER OR NORMAL SALINE, OCCAS IONALLY LIFTING UPPER AND LOWER LIDS, UNTIL NO EVIDENCE OF CHEMICAL REMAINS (APPROXIMATELY 15-20 MINUTES). GET MEDICAL ATTENTION IMMEDIATELY.

INGESTION

ETHYL ACETATE:

NARCOTIC.

ACUTE EXPOSURE- INGESTION OF SMALL AMOUNTS MAY CAUSE SORE THROAT, ABDOMINAL PAIN, AND DIARRHEA. LARGE AMOUNTS MAY CAUSE CENTRAL NERVOUS SYSTEM DEPRESSION, WITH DIZZINESS, HEADACHE, WEAKNESS, FATIGUE, DROWSINESS, AND UNCONSCIOUSNESS. POISONING MAY CAUSE CONGESTION OF THE LIVER AND KIDNEYS. CHRONIC EXPOSURE- ANIMALS FED 1000 MG/KG FOR I MONTH SHOWED NO EFFECTS.

FIRST AID- IF THE PERSON IS CONSCIOUS AND NOT CONVULSING, INDUCE EMESIS BY GIVING SYRUP OF IPECAC FOLLOWED BY WATER. (IF VOMITING OCCURS KEEP THE HEAD BELOW THE HIPS TO PREVENT ASPIRATION). REPEAT IN 20 MINUTES IF NOT EFFECTIVE INITIALLY. GIVE ACTIVATED CHARCOAL. IN PATIENTS WITH DEPRESSED RESPIRATION 
PAGE 5

OR IF EMESIS IS NOT PRODUCED, PERFORM GASTRIC LAVAGE CAUTIOUSLY (DREISBACH, HANDBOOK OF POISONING, 12TH ED.). TREAT SYMPTOMATICALLY AND SUPPORTIVELY. GASTRIC LAVAGE SHOULD BE PERFORMED BY QUALIFIED MEDICAL PERSONNEL. GET MEDICAL ATTENTION IMMEDIATELY.

ANTIDOTE:

NO SPECIFIC ANTIDOTE. TPEAT SYMPTOMATICALLY AND SUPPORTIVELY.

\section{REACTIVITY}

REACTIVITY:

STABLE UNDER NORMAL TEMPERATURES AND PRESSURES.

INCOMPATIBILITIES:

ETHYL ACETATE:

ACIDS (STRONG): EXOTHERMIC DECOMPOSITION.

BASES STRONG : EXOTHERMIC DECOMPOSITION.

CHLOROSULFONIC ACID: EXOTHERMIC DECOMPOSITION.

LITHIUM TETRAHYDROALUMINATE: POSSIBLE EXPLOSION.

NITRATES: FIRE AND EXPLOSION HAZARD.

OLEUM: EXOTHERMIC DECOMPOSITION.

OXIDIZERS (STRONG): FIRE AND EXPLOSION HAZARD.

POTASSIUM TERT-BUTOXIDE: POSSIBLE IGNITION.

DECOMPOSITION:

THERMAL DECOMPOSITION PRODUCTS MAY INCLUDE TOXIC OXIDES OF CARBON.

POLYMERIZATION:

HAZARDOUS POLYMERIZATION HAS NOT BEEN REPORTED TO OCCUR UNDER NORMAL TEMPERATURES AND PRESSURES.

OBSERVE ALL FEDERAL, STATE AND LOCAL REGULATIONS WHEN STORING OR DISPOSING OF THIS SUBSTANCE. FOR ASSISTANCE, CONTACT THE DISTRICT DIRECTOR OF THE ENVIRONMENTAL PROTECTION AGENCY.

**STORAGE**

STORE IN ACCORDANCE WITH 29 CFR 1910.106.

BONDING AND GROUNDING: SUBSTANCES WITH LOW ELECTROCONDUCTIVITY, WHICH MAY BE IGNITED BY ELECTROSTATIC SPARKS, SHOULD BE STORED IN CONTAINERS WHICH MEET THE BONDING AND GROUNDING GUIDELINES SPECIFIED IN NFPA 77-1983, RECOMMENDED PRACTICE ON STATIC ELECTRICITY.

STORE AWAY FROM INCOMPATIBLE SUBSTANCES.

**DISPOSAL** 
DISPOSAL MUST BE IN ACCORDANCE WITH STANDARDS APPLICABLE TO GENERATORS OF HAZARDOUS WASTE, 4OCFR 262. EPA HAZARDOUS WASTE NUMBER U112.

AVOID CONTACT WITH HEAT, SPARKS, FLAMES, OR OTHER SOURCES OF IGNITION. VAPORS MAY BE EXPLOSIVE AND POISONOUS; DO NOT ALLOW JNNECESSARY PERSONNEL IN AREA. DO NOT OVERHEAT CONTAINERS; CONTAINERS MAY VIOLENTLY RUPTURE AND TRAVEL A CONSIDERABLE DISTANCE IN HEAT OF FIRE.

SPILL AND LEAK PROCEDURES

OCCUPATIONAL SPILL:

SHUT OFF IGNITION SOURCES. STOP LEAK IF YOU CAN DO IT WITHOUT RISK. USE WATER SPRAY TO REDUCE VAPORS. FOR SMALL SPILLS, TAKE UP WITH SAND OR OTHER ABSORBENT MATERIAL AND PLACE INTO CONTAINERS FOR LATER DISPOSAL. FOR LARGER SPILLS, DIKE FAR AHEAD OF SPILL FOR LATER DISPOSAL. NO SMOKING, FLAMES OR FLARES' IN HAZARD AREA. KEEP UNNECESSARY PEOPLE AWAY; ISOLATE HAZARD AREA AND DENY ENTRY.

REPORTABLE QUANTITY (RQ): 5000 POUNDS

THE SUPERFUND AMENDMENTS AND REAUTHORIZATION ACT (SARA) SECTION 304 REQUIRES THAT A RELEASE EQUAL TO OR GREATER THAN THE REPORTABLE QUANTITY FOR THIS SUBSTANCE BE IMMEDIATELY REPORTED TO THE LOCAL EMERGENCY PLANNING COMMITTEE AND THE STATE EMERGENCY RESPONSE COMMISSION $(40$ CFR 355.40$)$. IF THE RELEASE OF THIS SUBSTANCE IS REPORTABLE UNDER CERCLA SECTION 103, THE NATIONAL RESPONSE CENTER MUST BE NOTIFIED IMMEDIATELY AT (800) 424-8802 OR (202) 426-2675 IN THE METROPOLITAN WASHINGTON, D.C. AREA (40 CFR 302.6).

\section{PROTECTIVE EQUIPMENT}

VENTILATION:

PROVIDE LOCAL EXHAUST OR PROCESS ENCLOSURE VENTILATION TO MEET THE PUBLISHED EXPOSURE LIMITS. VENTILATION EQUIPMENT MUST BE EXPLOSION-PROOF.

\section{RESPIRATOR:}

THE FOLLOWING RESPIRATORS AND MAXIMUM USE CONCENTRATIONS ARE RECOMMENDATIONS BY THE U.S. DEPARTMENT OF HEALTH AND HUMAN SERVICES, NIOSH POCKET GUIDE TO CHEMICAL HAZARDS; NIOSH CRITERIA DOCUMENTS OR BY THE U.S. DEPARTMENT OF LABOR, 29 CFR 1910 SUBPART 2.

THE SPECIFIC RESPIRATOR SELECTED MUST BE BASED ON CONTAMINATION LEVELS FOUND IN THE WORK PLACE, MUST NOT EXCEED THE WORKING LIMITS OF THE RESPIRATOR AND BE JOINTLY APPROVED BY THE NATIONAL INSTITUTE FOR OCCUPATIONAL SAFETY AND HEALTH AND THE MINE SAFETY AND HEAL'TH ADMINISTRATION (NIOSH-MSHA).

\section{ETHYL ACETATE:}

1000 PPM- ANY CHEMICAL CARTRIDGE RESPIRATOR WITH A FULL FACEPIECE AND ORGANIC VAPOR CARTRIDGE(S).

ANY POWERED, AIR-PURIFYING RESPIRATOR WITH ORGANIC VAPOR CARTRIOGE $(S)$. 


\section{MSDS\#2027 PAGE}

10,000 PPM- ANY AIR-PURIFYING, FULL-FACEPIECE RESPIRATOR (GAS MASK) WITH A CHIN-STYLE, FRONT- OR BACK-MOUNTED ORGANIC VAPOR CANISTER. ANY SELF-CONTAINED BREATHING APPARATUS WITH A FULL FACEPIECE. ANY SUPPLIED-AIR RESPIRATOR WITH A FULL FACEPIECE. ANY SUPPLIED-AIR RESPIRATOR OPERATED IN A CONTINUOUS-FLOW MODE.

ESCAPE- ANY AIR-PURIFYING, FULL-FACEPIECE RESPIRATOR (GAS MASK) WITH A CHIN-STYLE, FRONT-OR BACK-MOUNTED ORGANIC VAPOR CANISTER. ANY APPROPRIATE ESCAPE-TYPE, SELF-CONTAINED BREATHING APPARATUS.

FOR FIREFIGHTING AND OTHER IMMEDIATELY DANGEROUS TO LIFE OR HEALTH CONDITIONS:

ANY SELF-CONTAINED BREATHING APPARATUS THAT HAS A FULL FACEPIECE AND IS OPERATED IN A PRESSURE-DEMAND OR OTHER POSITIVE-PRESSURE MODE.

ANY SUPPLIED-AIR RESPIRATOR THAT HAS A FULL FACEPIECE AND IS OPERATED IN A PRESSURE-DEMAND OR OTHER POSITIVE-PRESSURE MODE IN COMBINATION WITH AN AUXILIARY SELF-CONTAINED BREATHING APPARATUS OPERATED IN PRESSURE-DEMAND OR OTHER POSITIVE-PRESSURE MODE.

CLOTHING:

EMPLOYEE, MUST WEAR APPROFRIATE PROTECTIVE (IMPERVIOUS) CLOTHING AND EQUIPMENT TO PREVENT REPEATED OR PROLONGED SKIN CONTACT WITH THIS SUBSTANCE.

GLOVES:

EMPLOYEE MUST WEAR APPROPRIATE PROTECTIVE GLOVES TO PREVENT CONTACT WITH THIS SUBSTANCE.

EYE PROTECTION:

EMPLOYEE MUST WEAR SPLASH-PROOF OR DUST-RESISTANT SAFETY GOGGLES TO PREVENT EYE CONTACT WITH THIS SUBSTANCE.

EMERGENCY EYE WASH: WHERE THERE IS ANY POSSIBILITY THAT AN EMPLOYEE'S EYES MAY BE EXPOSED TO THIS SUBSTANCE. THE EMPLOYER SHOULD PROVIDE AN EYE WASH FOUNTAIN WITHIN THE IMMEDIATE WORK AREA FOR EMERGENCY USE.

AUTHORIZED BY - OCCUPATIONAL HEALTH SERVICES, INC.

OHS08750 CREATION DATE: $10 / 09 / 84$ REVISION DATE: $05 / 27 / 91$

$141-78-5$

ETHYL ACETATE

Copyright 1991 Occupational Health Services, Inc. All Rights Reserved. Licensed to: Hanford Environmental Health Foundation

To make unlimited paper copies for internal distribution and use only. 
OHS24940

MATERIAL SAFETY DATA SHEET

MSDS \#4989

OCCUPATIONAL HEALTH SERVICES, INC.

FOR EMERGENCY SOURCE INFORMATION

11 WEST 42ND STREET, 12TH FLOOR

CONTACT: $1-615-366-2000$

NEW YORK, NEW YORK 10036

$1-800-445-$ MSOS $(1-800-445-6737)$ OR

$1-212-789-3535$

SUBSTANCE IDENTIFICATION

SUBSTANCE: VINYL CHLORIDE

CAS-NUMBER 75-01-4

TRADE NAMES/SYNONYMS:

CHLOROETHYLENE; CHLOROETHENE; CHLORETHENE; TROVIDUR; ETHYLENE MONOCHLORIDE; MONOCHLOROETHYLENE; EXON 470; MONOCHLORO ETHENE; VINYL CHLORIDE MONOMER; VINYL CHLORIDE, INHIBITED; STCC 4905792; RCRA U043; UN 1086; C2H3CL; OHS24940

CHEMICAL FAMILY:

HALOGEN COMPOUND, ALIPHATIC

MOLECULAR FORMULA: C-H2-C-H-CL

MOLECULAR WEIGHT: 62.50

CERCLA RATINGS (SCALE $0-3$ ): HEALTH=3 FIRE $=3$ REACTIVITY $=2$ PERSISTENCE $=3$ NFPA RATINGS (SCALE 0-4): HEALTH=2 FIRE=4 REACTIVITY $=1$

COMPONENTS AND CONTAMINANTS

COMPONENT: VINYL CHLORIDE
CAS\# 75-01-4

PERCENT: $>99.9$

OTHER CONTAMINANTS: MAY CONTAIN TRACES OF PHENOL OR OTHER INHIBITORS

EXPOSURE LIMITS:

VINYL CHLORIDE:

1.0 PPM OSHA TWA; 5 PPM OSHA 15 MINUTE CEILING;

0.5 PPM OSHA ACTION LEVEL AS AN 8 HOUR TWA

5 PPM ACGIH TWA

ACGIH Al-CONFIRMED HUMAN CARCINOGEN.

LOWEST FEASIBLE LIMIT NIOSH RECOMMENDED EXPOSURE CRITERIA

MEASUREMENT METHOD: CHARCOAL TUBE (2); CARBON DISULFIDE; GAS CHROMATOGRAPHY WITH FLAME IONIZATION DETECTION; (NIOSH VOL. III \# 1007).

1 POUND CERCLA SECTION 103 REPORTABLE QUANTITY

SUBJECT TO SARA SECTION 313 ANNUAL TOXIC CHEMICAL RELEASE REPORTING

SUBJECT TO CALIFORNIA PROPOSITION 65 CANCER AND/OR REPRODUCTIVE TOXICITY

WARNING AND RELEASE REQUIREMENTS- (FEBRUARY 27, 1987) 
PAGE 2

PHYSICAL DATA

DESCRIPTION: COLORLESS GAS WITH A MILD, SWEET ODOR.

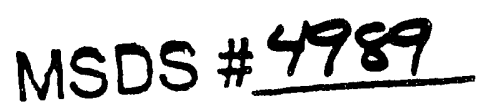

BOILING POINT: $9 \mathrm{~F}(-13 \mathrm{C})$ MELTING POINT: $-245 \mathrm{~F}(-154 \mathrm{C})$

SPECIFIC GRAVITY: 0.9106 VAPOR PRESSURE: 2515.6 MMHG $21.1 \mathrm{C}$

SOLUBILITY IN WATER: $0.25 \%$ ODOR THRESHOLD: 260 PPM VAPOR DENSITY: 2.2

SOLVENT SOLUBILITY: SOLUBLE IN ALCOHOL, ETHER, CARBON TETRACHLORIDE, BENZENE.

VISCOSITY: $0.01072 C P \odot 20 C$ (GAS); $0.280 \mathrm{CP} \odot-20 \mathrm{C}$ (LIQUID)

FIRE AND EXPLOSION DATA

FIRE AND EXPLOSION HAZARD:

DANGEROUS FIRE HAZARD WHEN EXPOSED TO HEAT OR FLAME.

DANGEROUS EXPLOSION HAZARD WHEN EXPOSED TO HEAT OR FLAME.

VAPORS ARE HEAVIER THAN AIR AND MAY TRAVEL A CONSIDERABLE DISTANCE TO A SOURCE OF IGNITION AND FLASH BACK.

VAPOR-AIR MIXTURES ARE EXPLOSIVE.

DUE TO LOW ELECTROCONDUCTIVITY OF THE SUBSTANCE, FLOW OR AGITATION MAY

GENERATE ELECTROSTATIC CHARGES RESULTING IN SPARKS WITH POSSIBLE IGNITION.

FLASH POINT: $-108 \mathrm{~F}(-78 \mathrm{C})$ UPPER EXPLOSIVE LIMIT: $33 \%$

LOWER EXPLOSIVE LIMIT: $3.6 \%$ AUTOIGNITION TEMP.: 882 F $(472 \mathrm{C})$

FIREFIGHTING MEDIA:

DRY CHEMICAL OR CARBON DIOXIDE

(1990 EMERGENCY RESPONSE GUIDEBOOK, DOT P 5800.5).

FOR LARGER FIRES, USE WATER SPRAY, FOG OR REGULAR FOAM

(1990 EMERGENCY RESPONSE GUIDEBOOK, IOT P 5800.5).

FIREFIGHTING :

MOVE CONTAINER FROM FIRE AREA IF YOU CAN DO IT WITHOUT RISK. FOR MASSIVE FIRE IN CARGO / DEA, USE UNMANNED HOSE HOLDER OR MONITOR NOZZLES; IF THIS IS

IMPOSSIBLE, WITHDRAW FROM AREA AND LET FIRE BURN. WITHDRAW IMMEDIATELY IN CASE OF RISING SOUND FROM VENTING SAFETY DEVICE OR ANY DISCOLORATION OF TANK DUE TO FIRE. COOL CONTAINER WITH WATER USING UNMANNED DEVICE UNTIL WELL AFTER FIRE IS OUT. LET TANK, TANK CAR OR TANK TRUCK BURN UNLESS LEAK CAN BE STOPPED; WITH SMALLER TANKS'OR CYLINDERS, EXTINGUISH/ISOLATE FROM OTHER FLAMMABLES. ISOLATE FOR $1 / 2$ MILE IN ALL DIRECTIONS IF TANK, RAIL CAR OR TANK TRUCK IS INVOLVED IN FIRE (1990 EMERGENCY RESPONSE GUIDEBOOK, DOT P 5800.5, GUIDE PAGE 17). 
PAGE 3

EXTINGUISH ONLY IF FLOW CAN BE STOPPED; USE WATER IN FLOODING QUNATITIES AS FOG. COOL CONTAINERS WITH FLOODING AMOUNTS OF WATER, APPLY FROM AS FAR A DISTANCE AS POSSIBLE. AVOID BREATHING TOXIC VAPORS, KEFP UPWIND. EVACUATE TO A RADIUS OF 2500 FEET FOR UNCONTROLLABLE FIRES. CONSIDER EVACUATION OF DOWNWIND AREA IF MATERIAL IS LEAKING.

STOP FLOW OF GAS (NFPA 325M, FIRE HAZARD PROPERTIES OF FLAMMABLE LIQUIDS, GASES, ANID VOLATILE SOLIDS, 1984).

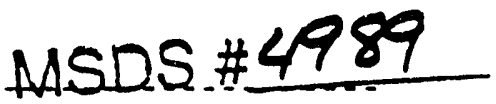

TRANSPORTATION DATA

DEPARTMENT OF TRANSPORTATION HAZARD CLASSIFICATION 49 CFR 172.101:

FLAMMABLE GAS

DEPARTMENT OF TRANSPORTATION LABELING REQUIREMENTS 49 CFR 172.101 AND SUBPART E:

FLAMMABLE GAS

DEPARTMENT OF TRANSPORTATION PACKAGING REQUIREMENTS: 49 CFR 173.304;

49 CFR 173.314 AND 49 CFR 173.315

EXCEPTIONS: 49 CFR 173.306

\section{TOXICITY}

VINYL CHLORIDE:

TOXICITY DATA: $500 \mathrm{MG} / \mathrm{KG}$ ORAL-RAT LD50; $18 \mathrm{PPH} / 15$ MINUTES INHALATION-RAT LC50; 200 PPM/18 MINUTES INHALATION-RAT LC50; MUTAGENIC DATA (RTECS); REPRODUCTIVE EFFECTS DATA (RTECS); TUMORIGENIC DATA (RTECS).

CARCINOGEN STATUS: OSHA CARCINOGEN; KNOWN HUMAN CARCINOGEN (NTP); HUMAN SUFF ICIENT EVIDENCE, ANIMAL SUFFICIENT EVIDENCE (IARC GROUP-1). STUDIES SHOW OCCUPATIONAL EXPOSURE RESULTED IN A SIGNIFICANT INCREASE IN ANGIOSARCOMAS OF THE LIVER, AND ALSO TUMORS OF THE BRAIN, LUNG, AND HEMATOPOIETIC SYSTEMS. VINYL CHLORIDE WAS CARCINOGENIC IN RATS, MICE, AND HAMSTERS FOLLOWING ORAL AND INHALATION EXPOSURE, PROOUCING ANGIOSARCOMAS OF THE LIVER AND ALSO TUMORS AT VARIOUS SITES, AND WAS CARCINOGENIC IN RATS FOLLOWING PRENATAL EXPOSURE.

LOCAL EFFECTS: IRRITANT- SKIN, EYE.

ACUTE TOXICITY LEVEL: TOXIC BY INGESTION; RELATIVELY NON-TOXIC BY INHALATION.

TARGET EFFECTS: CENTRAL NERVOUS SYSTEM DEPRESSANT. POISONING MAY AFFECT THE BLOOD, LIVER, AND LYMPHATIC AND RESPIRATORY SYSTEMS.

ADOITIONAL DATA: STIMULANTS SUCH AS EPINEPHRINE MAY INDUCE VENTRICULAR FIBRILLATION.

HEALTH EFFECTS AND FIRST AID

INHALATION:

VINYL CHLORIDE:

NARCOTIC/CARCINOGEN.

ACUTE EXPOSURE- MAY BE IRRITATING. EXPOSURE TO 1000-16,000 PPM MAY CAUSE CENTRAL NERVOUS SYSTEM DEPRESSION WITH DROWSINESS, VERTIGO, STAGGERING GAIT, TINGLING AND NUMBNESS OF HANDS AND FEET, IMPAIRED 
HEARING AND VISION, CARDIAC ARRHYTHMIAS AND POSSIBLY UNCONSCIOUSNESS; 20,000-25,000 PPM FOR 3-5 MINUTES MAY CAUSE DIZZINESS, LIGHTHEADEDNESS, DISORIENTATION, NAUSEA AND BURNING SENSATION OF THE SOLES

OF THE FEET; AND 120,000 PPM MAY BE FATAL. ADDITIONAL EFFECTS MAY INCLUDE NARCOLEPSY, HEADACHE, UNDUE FATIGUE, MUSCLE AND JOINT PAIN, DYSPNEA, AND ANESTHESIA. DEATH MAY BE DUE TO RESPIRATORY PARALYSIS WITH CARDIAC ARREST. HUMAN ANO ANIMAL PATHOLOGIC REPORTS SHOW PULMONARY EDEMA, HYPEREMIA OF KIDNEYS AND LIVER, AND HEPATIC DEGENERATION.

CHRONIC EXPOSURE- REPEATED EXPOSURE MAY RESULT IN DOSE-RELATED SENSORY OISORDERS, AUTONOMIC NERVOUS SYSTEM POLYNEURITIS, SPASTIC ANGIONEURITIS, LEUKOPENIA, THROMBOCYTOPENIA, SPLENOMEGALY, HEPATITIS-LIKE LIVER CHANGES, LIVER MALFUNCTION WITH PORTAL FIBROSIS, IMPOTENCE AND PULMONARY INSUFFICIENCY. WORKERS INVOLVED IN THE POLYMERIZATION PROCESS MAY EXHIBIT A PECULIAR TRIAD OF SYMPTOMS: MOOIFICATION OF PERIPHERAL CIRCULATION RESULTING IN PALLOR, CYANOSIS, AND THEN REDNESS (RAYNAUD'S PHENOMENON); SKELETAL CHANGES OF' DISTAL PHALANGES (ACRO-OSTEOLYSIS); AND SCLERODERMÁ LIKE SKIN CHANGES. PSEUDO-CLUBBING OF THE FINGERS MAY ALSO OCCUR. OCCUPATIONAL EXPOSURE HAS PRODUCED ANGIOSARCOMAS OF THE LIVER AND IS ASSOCIATED WITH TUMOR PRODUCTION AT OTHER SITES. ANIMAL STUDIES SHOW THAT VINYL CHLORIDE IS CARCINOGENIC IN RATS FOLLOWING PRENATAL EXPOSURE. ONE STUDY SUGGESTED AN INCREASED FETAL MORTALITY DUE TO EXPOSURE OF THE FATHERS TO VINYL CHLORIDE. SEVERAL STUDIES HAVE REPORTED AN INCREASED RATE OF BIRTH DEFECTS, ESPECIALLY CENTRAL NERVOUS SYSTEM ANOMALIES, IN THE CHILDREN OF PARENTS RESIDING IN COMMUMITIES WHERE VINYL CHLORIDE PRODUCTION AND POLYMERIZATION PLANTS ARE LOCATED.

FIRST AID- REMOVE FROM EXPOSURE AREA TO FRESH AIR IMMEDIATELY. IF BREATHING HAS STOPPED, GIVE ARTIFICIAL RESPIRATION. MAINTAIN AIRWAY AND BLOOD PRESSURE AND ADMINISTER OXYGEN IF AVAILABLE. KEEP AFFECTED PERSON WARM AND AT REST. TREAT SYMPTOMATICALLY AND SUPPORTIVELY. ADMINISTRATION OF OXYGEN SHOULD BE PERFORMED BY QUALIFIED PERSONNEL. GET MEDICAL ATTENTION IMMEDIATELY.

SKIN CONTACT:

VINYL CHLORIDE:

IRRITANT.

ACUTE EXPOSURE- CONTACT MAY CAUSE IRRITATIOI: WITH REDNESS ANT PAIN. DUE TO RAPID EVAPORATION, THE LIQUID MAY CAUSE FROSTBITE WITH REDNESS, TINGLING, AND PAIN OR NUMBNESS. IN MORE SEVERE CASES, THE SKIN MAY BECOME HARD AND WHITE AND DEVELOP BLISTERS.

CHRONIC EXPOSURE- WORKERS HANOLING VINYL CHLORIDE HAVE EXHIBITED A PECULIAR TRIAD OF SYMPTOMS: RAYNAUD'S PHENOMENON, ACRO-OSTEOLYSIS, AND SCLERODERMA LIKE SKIN CHANGES. REPEATED' OR PROLONGED EXPOSURE TO IRRITANTS MAY CAUSE DERMATITIS.

FIRST AID- REMOVE CONTAMINATED CLOTHING AND SHOES IMMEDIATELY. WASH AFFECTED AREA WITH SOAP OR MILD OETERGENT AND LARGE AMOUNTS OF WATER UNTIL NO EVIDENCE OF CHEMICAL REMAINS. IN CASE OF FROSTBITE, WARM AFFECTED SKIN IN WARM WATER AT A TEMPERATURE OF $107 \mathrm{~F}$. IF WARM WATER' IS NOT AVAILABLE OR IMPRACTICAL TO USE, GENTLY WRAP AFFECTED PART IN BLANKETS. ENCOURAGE VICTIM TO EXCERCISE AFFECTED PART WHILE IT IS BEING WARMED. ALLOW CIRCULATION TO RETURN NATURALLY (MATHESON GAS, 6TH ED.). GET MEDICAL ATTENTION IMMEDIATELY. 
EYE CONTACT:

VINYL CHLORIDE:

\section{MSDS \#4989}

IRRITANT.

ACUTE EXPOSURE- CONTACT MAY CAUSE IMMEDIATE AND SEVERE IRRITATION, AND CORNEAL INJURY WITH COMPLETE RECOVERY IN 48 HOURS. DUE TO RAPID EVAPORATION, THE LIQUID MAY CAUSE FROSTBITE WITH REDNESS, PAIN AND BLURRED VISION.

CHRONIC EXPOSURE- REPEATED OR PROLONGED EXPOSURE TO IRRITANTS MAY CAUSE CONJUNCTIVITIS.

FIRST AID- IMMEDIATELY WASH THE EYES WITH LARGE AMOUNTS OF WATER, OCCASIONALLY LIFTING UPPER AND LOWER LIDS, UNTIL NO EVIDENCE OF CHEMICAL REMAINS (APPROXIMATELY 15-20 MINUTES). IF FROSTBITE IS PRESENT, WARM WATER MAY BE PREFERRED. GET MEDICAL ATTENTION IMMEDIATELY.

INGESTION:

VINYL CHLORIDE:

CARCINOGEN/TOXIC.

ACUTE EXPOSURE- THE REPORTED LETHAL DOSE IN RATS IS $500 \mathrm{MG} / \mathrm{KG}$. THE SYMPTOMS WERE NOT REPORTED. IF THE LIQUID IS SWALLOWED, FROSTBITE DAMAGE TO THE LIPS, MOUTH AND MUCOUS MEMBRANES MAY OCCUR.

CHRONIC EXPOSURE- ORAL ADMINISTRATION TO RATS, MICE, AND HAMSTERS RESULTED IN TUMOR PRODUCTION AT VARIOUS SITES, INCLUDING ANGIOSARCOMAS OF THE LIVER.

FIRST AID- IF EXTENSIVE : MMITING HAS NOT OCCURRED, THE SUBSTANCE SHOULD BE REMOVED BY EMESIS OR GASTRIC LAVAGE PROVIDED THAT THE PATIENT IS CONSCIOUS AND CONVULSIONS ARE NOT PRESENT. KEEP HEAD BELOW HIPS DURING VOMITING TO PREVENT ASPIRATION. DO NOT ATTEMPT TO MAKE AN UNCONSCIOUS PERSON VOMIT. TREAT SYMPTOMATICALLY AND SUPPORTIVELY. GET MEDICAL ATTENTION IMMEDIATELY (ORE ISBACH, HANDBOOK OF POISONING, 12TH ED.). TREATMENT SHOULD BE PERFORMED BY QUALIFIED MEDICAL PERSONNEL.

ANTIDOTE:

NO SPECIFIC ANTIDOTE. TREAT SYMPTOMATICALLY AND SUPPORTIVELY.

REACTIVITY

REACTIVITY:

FORMS UNSTABLE PEROXIDES WHEN EXPOSED TO AIR WHICH MAY INITIATE

POLYMERIZATION. MAY ALSO POLYMERIZE ON EXPOSURE TO HEAT OR LIGHT.

INCOMPATIBILITIES:

VINYL CHLORIDE:

ACETYLIDE-FORMING MATERIALS: MAY FORM EXPLOSIVE COMPOUNDS.

ALUMINUM: MAY CAUSE POLYMERIZATION.

COPPER AND ALLOYS: MAY FORM EXPLOSIVE COMPOUNDS.

IRON: MAY CORRODE IN THE PRESENCE OF WATER.

MONEL: MAY FORM EXPLOSIVE COMPOUND.

NITROGEN OXIDES: EXPLODES.

OXIDIZERS (STRONG): FIRE AND EXPLOSION HAZARD.

PEROXII S: MAY INITIATE POLYMERIZATION. 
STEEL: MAY CORRODE IN THE PRESENCE OF WATER.

DECOMPOSITION:

THERMAL DECOMPOSITION PRODUCTS MAY INCLUDE HIGHLY TOXIC FUMES OF PHOSGENE, TOXIC AND CORROSIVE FUMES OF CHLORIDES, AND OXIDES OF CARBON.

POLYMERIZATION:

POLYMERIZATION OCCURS ON EXPOSURE TO SUNLIGHT, HEAT, OR AIR. THE PRESENCE OF IMPURITIES MAY RESULT IN EXOTHERMIC SELF-POLYMERIZATION, GENERATING SUFFICIENT HEAT AND PRESSURE TO RUPTURE THE CONTAINER.

MSDS \#4989

STORAGE AND DISPOSAL

OBSERVE ALL FEDERAL, STATE AND LOCAL REGULATIONS WHEN STORING OR DISPOSING OF THIS SUBSTANCE. FOR ASSISTANCE, CONTACT THE DISTRICT DIRECTOR OF THE ENVIRONMENTAL PROTECTION AGENCY.

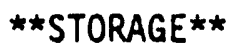

STORE IN ACCORNANCE WITH 29 CFR 1910.101.

PROTECT AGAINST PHYSICAL DAMAGE. OUTSIDE OR DETACHED STORAGE IS PREFERABLE. INSIDE STORAGE SHOULD BE IN A COOL, WELL-VENTILATED, NON-COMBUSTIBLE LOCATION, AWAY FROM ALL POSSIBLE SOURCES OF IGNITION. SEPARATE FROM OXIDIZING MATERIALS. (NFPA 49, HAZARDOUS CHEMICALS DATA, 1975).

BONDING AND GROUNDING: SUBSTANCES WITH LOW ELECTROCONDUCTIVITY, WHICH MAY BE IGNITED BY ELECTROSTATIC SPARKS, SHOULD BE STORED IN CONTAINERS WHICH MEET THE BONDING AND GROUNDING GUIDELINES SPECIFIED IN NFPA 77-1983, RECOMMENDED PRACTICE ON STATIC ELECTRICITY.

*\#ISPOSAL **

DISPOSAL MUST BE IN ACCORDANCE WITH STANDAROS APPLICABLE TO GENERATORS OF HAZARDOUS WASTE, 40CFR 262. EPA HAZARDOUS WASTE NUMBER U043.

VINYL CHLORIDE - REGULATORY LEVEL: $0.2 \mathrm{MG} / \mathrm{L}$

MATERIALS WHICH CONTAIN THE ABOVE SUBSTANCE AT OR ABOVE THE REGULATORY

LEVEL MEET THE EPA CHARACTERISTIC OF TOXICITY, AND MUST BE DISPOSED OF IN ACCORDANCE WITH 40 CFR PART 262. EPA HAZARDOUS WASTE NUMBER D043.

MATERIAL IS EXTREMELY FLAMMABLE; AVOID CONTACT WITH HEAT, SPARKS, FLAMES OR OTHER SOURCES OF IGNITION. CONTENTS ARE UNDER PRESSURE; CONTAINERS MAY RUPTURE VIOLENTLY AND TRAVEL A CONSIDERABLE DISTANCE.

SPILL AND LEAK PROCEDURES 
WATER SPILL:

THE CALIFORNIA SAFE ORINKING WATER AND TOXIC ENFORCEMENT ACT OF 1986

(PROPOSITION 65) PROHIBITS CONTAMINATING ANY KNOWN SOURCE OF DRINKING WATER WITH SUBSTANCES KNOWN TO CAUSE CANCER AND/OR REPRODUCTIVE TOXICITY.

OCCUPATIONAL SPILL:

SHUT OFF IGNITION SOURCES. STOP LEAK IF YOU CAN DO IT WITHOUT RISK. USE WATER SPRAY TO REDUCE VAPORS. ISOLATE AREA UNTIL GAS HAS DISPERSED. NO SMOKING, FLAMES OR FLARES IN HAZARD AREA! KEEP UNNECESSARY PEOPLE AWAY; ISOLATE HAZARD AREA AND DENY ENTRY. VENTILATE CLOSED SPACES BEFORE ENTERING.

REPURTABLE QUANTITY (RQ): I POUND

THE SUPERFUND AMENDMENTS AND REAUTHORIZATION ACT (SARA) SECTION 304 REQUIRES

THAT A RELEASE EQUAL TO OR GREATER THAN THE REPORTABLE QUANTITY FOR THIS

SUBSTANCE BE IMMEDIATELY REPORTED TO THE LOCAL EMERGENCY PLANNING COMMITTEE

AND THE STATE EMERGENCY RESPONSE COMMISSION $(40$ CFR 355.40). IF THE RELEASE OF THIS SUBSTANCE IS REPORTABLE UNDER CERCLA SECTION 103, THE NATIONAL RESPONSE CENTER MUST BE NOTIFIED IMMEDIATELY AT (800) 424-8802 OR (202) 426-2675 IN THE METROPOLITAN WASHINGTON, D.C. AREA (40 CFR 302.6).

\section{PROTECTIVE EQUIPMENT}

VENTILATION:

PROVIDE LOCAL EXHAUST OR PROCESS ENCLOSURE VENTILATION TO MEET THE PUBLISHED EXPOSURE LIMITS. VENTILATION EQUIPMENT MUST BE EXPLOSION-PROOF.

VINYL CHLORIDE:

VENTILATION SHOULD MEET THE REQUIREMENTS IN 29 CFR 1910.1017(F).

RESPIRATOR:

THE FOLLOWING RESPIRATORS ARE THE MINIMUM LEGAL REQUIREMENTS AS SET FORTH BY THE OCCUPATIONAL SAFETY AND HEALTH ADMINISTRATION FOUND IN 29 CFR 1910 , SUBPART $Z$.

REQUIRED RESPIRATORS FOR VINYL CHLORIDE

ATMOSPHERIC CONCENTRATIONS OF VINYL CHLORIOE

JNKNOWN OR ABOVE 3600 PPM

NOT OVER 3600 PPM

\section{REQUIRED APPARATUS}

OPEN-CIRCUIT, SELF CONTAINED

BREATHING APPARATUS, PRESSURE

DEMAND TYPE, WITH FULL FACEPIECE

COMBINATION TYPE ' $C$ ' SUPPLIED AIR RESPIRATOR, PRESSURE DEMAND TYPE, WITH A FULL OR HALF FACEPIECE AND AUXILIARY SELF-CONTAINED AIR SUPPLY; $O R$ COMBINATION TYPE SUPPLIED AIR RESPIRATOR, CONTINUOUS FLOW TYPE, WITH A FULL OR HALF FACEPIECE, 
NOT OVER 1000 PPM

NOT OVER 100 PPM

NOT OVER 25 PPM

NOT OVER 10 PPM
AND AUXILIARY SELF-CONTAINED AIR SUPPLY.

TYPE ' $C$ ' SUP'LIED AIR RESPIRATOR, CONTINUOUS FLOW TYPE, WITH A FULL OR HALF FACEPIECE, HELMET OR HOOD.

COMBINATION TYPE ' $C$ ' SUPPLIED AIR RESPIRATOR, DEMAND TYPE, WITH A

FULL FACEPIECE, AND AUXILIARY SELF-CONTAINED AIR SUPPLY;

OPEN-CIRCUIT SELF-CONTAINED

BREATHING APPARATUS WITH A FULL

FACEPIECE, IN DEMAND MODE; OR

TYPE ' $C$ ' SUPPLIED AIR RESPIRATOR, DEMAND TYPE, WITH FULL FACEPIECE.

A POWERED AIR PURIFYING RESPIRATOR WITH HOOD, HELMET, FULL OR HALF FACEPIECE, AND A CANISTER WHICH PROVIDES A SERVICE LIFE OF AT LEAST 4 HOURS FOR CONCENTRATIONS OF VINYL CHRLORIDE UP TO 25 PPM;

$O R$

GAS MASK, FRONT - OR BACK-MOUNTED CANISTER WHICH PROVIDES A SERVICE LIFE OF AT LEAST 4 HOURS FOR CONCENTRATIONS OF VINYL CHORIDE UP TO 25 PPM.

COMBINATION TYPE ' $C$ ' SUPPLIED AIR RESPIRATOR, WITH A HALF FACEPIECE AND AUXILIARY SELF-CONTAINED AIR SUPPLY;

$O R$

TYPE ' $C$ ' SUPPLIED-AIR RESPIRATOR, DEMAND TYPE, WITH A HALF

FACEPIECE;

ANY CHEMICAL CARTRIDGE RESPIRATOR WITH AN ORGANIC VAPOR CARTRIDGE WHICH PROVIDES A SERVICE LIFE OF AT LEAST I HOUR FOR CONCENTRATIONS OF VINYL CHLORIDE UP TO 10 PPM.

ENTRY INTO UNKNOWN CONCENTRATIONS OR CONCENTRATIONS GREATER THAN 36,000 PPM (LOWER EXPLOSION LIMIT) MAY BE MADE ONLY FOR THE PURPOSES OF LIFE RESCUE; AND

ENTRY INTO CONCENTRATIONS OF LESS THAN 36,000 PPM, BUT GREATER THAN 3600 PPM 
PAGE 9

MAY BE MADE ONLY FOR THE PURPOSES OF LIFE RESCUE, FIREFIGHTING OR SECURING EQUIPMENT SO AS TO PREVENT A GREATER HAZARD OF RELEASE OF VINYL CHLORIDE.

THE FOLLOWING RESPIRATORS AND MAXIMUM USE CONCENTRATIONS ARE RECOMMENDATIONS BY THE U.S. DEPARTMENT OF HEALTH AND HUMAN SERVICES, NIOSH POCKET GUIDE TO CHEMICAL HAZARDS, OR NIOSH CRITERIA DOCUMENTS.

THE SPECIFIC RESPIRATOR SELECTED MUST BE BASED ON CONTAMINATION LEVELS FOUND IN THE WORK PLACE, MUST NOT EXCEED THE WORKING LIMITS OF THE RESPIRATOR AND BE JOINTLY APPROVED BY THE NATIONAL INSTITUTE FOR OCCUPATIONAL SAFETY AND HEALTH AND THE MINE SAFETY AND HEALTH ADMINISTRATION (NIOSH-MSHA).

VINYL CHLORIDE (AT ANY DETECTABLE CONCENTRATION):

SELF-CONTAINED BREATHING APPARATUS WITH FULL FACEPIECE OPERATED IN PRESSURE-DEMAND OR OTHER POSITIVE PRESSURE MODE.

SUPPLIED-AIR RESPIRATOR WITH FULL FACEPIECE OPERATED IN PRESSURE-DEMAND OR OTHER POSITIVE PRESSURE MODE IN COMBINATION WITH AN AUXILIARY SELF-CONTAINED BREATHING APPARATUS OPERATED IN PRESSURE-DEMAND OR OTHER POSITIVE PRESSURE MODE.

ESCAPE - AIR-PURIFYING FULL FACEPIECE RESPIRATOR (GAS MASK) WITH A CHIN-STYLE OR FRONT- OR BACK-MOUNTED CANISTER PROVIDING PROTECTION AGAINST VINYL CHLORIDE.

ESCAPE-TYPE SELF-CONTAINED BREATHING APPARATUS.

FOR FIREFIGHTING AND OTHER IMMEDIATELY DANGEROUS TO LIFE OR HEALTH CONDITIONS:

ANY SELF-CONTAINED BREATHING APPARATUS THAT HAS A FULL FACEPIECE AND IS OPERATED IN A PRESSURE-DEMAND OR OTHER POSITIVE-PRESSURE MODE.

ANY SUPPLIED-AIR RESPIRATOR THAT HAS A FULL FACEPIECE AND IS OPERATED IN A PRESSURE-DEMAND OR OTHER POSITIVE-PRESSURE MODE IN COMBINATION WITH AN AUXILIARY SELF-CONTAINED BREATHING APPARATUS OPERATED IN PRESSURE-DEMAND OR OTHER POSITIVE-PRESSURE MODE.

CLOTHING:

EMPLOYEE MUST WEAR APPROPRIATE PROTECTIVE (IMPERVIOUS) CLOTHING AND EQUIPMENT TO PREVENT ANY POSSIBILITY OF SKIN CONTACT WITH THIS SUBSTANCE.

VINYL CHLORIDE:

PROTECTIVE CLOTHING SHOULD MEET THE REQUIREMENTS FOR PROTECTIVE GARMENTS IN 29 CFR $1910.1017(\mathrm{H})$.

GLOVES:

FOR GAS: WEAR IMPERVIOUS GLOVES. SPECIFIC TYPE OF GLOVE MAY BE TESTED AND/OR RECOMMENDED BY MANUFACTURER.

FOR COMPRESSED LIQUID: WEAR FULL PROTECTIVE, COLD INSULATINE GLOVES.

VINYL CHLORIDE:

PROTECTIVE GLOVES SHOULD MEET THE REQUIREMENTS FOR PROTECTIVE GARMENTS IN 29 CFR $1910.1017(H)$.

EYE PROTECTION: 
EMPLOYEE MUST WEAR SPLASH-PROOF OR OUST-RESISTANT SAFETY GOGGLES AND A FACESHIELD TO PREVENT CONTACT WITH THIS SUBSTANCE.

EMERGENCY WASH FACILITIES:

WHERE THERE IS ANY POSSIBILITY THAT AN EMPLOYEE'S EYES AND/OR SKIN MAY BE EXPOSED TO THIS SUBSTANCE, THE EMPLOYER SHOULD PROVIDE AN EYE WASH FOUNTAIN AND QUICK ORENCH SHOWER WITHIN THE IMMEDIATE WORK AREA FOR EMERGENCY USE.

VINYL CHLORIDE:

PROTECTIVE EYE EQUIPMENT SHOULD MEET THE REQUIREMENTS FOR PROTECTIVE GARMENTS IN 29 CFR $1910.1017(\mathrm{H})$.

OHS24940

AUTHORIZED BY - OCCUPATIONAL HEALTH SERVICES, INC.

75-01-4

VINYL CHLORIDE

REVISION DATE: $04 / 11 / 91$

\section{CREATION DATE: $10 / 16 / 84$}

Copyright 1991 Occupational Health Services, Inc. All Rights Reserved.

Licensed to: Hanford Environmental Health Foundation

To make uni imited paper copies for internal distribution and use only. 
D0E/RL-90-04, Rev. 2

$12 / 15 / 93$

\section{APPENDIX E}

\section{PERSONNEL TRAINING}


곻
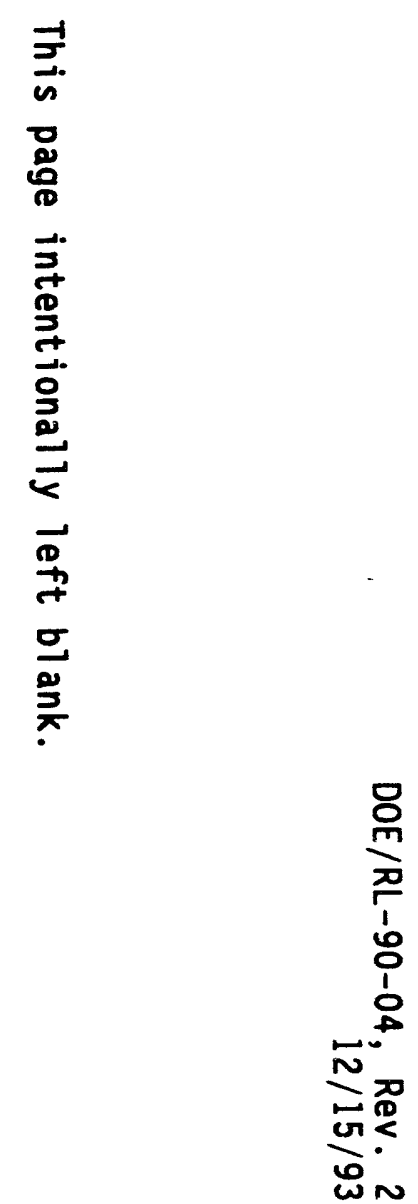
1 Title:

2 Description:

Technique:

5 Evaluation:

6 Length:

7 Frequency:

Generator Hazards Safety Training

Provides the dangerous material/waste worker with the fundamentals for safe use and disposal of dangerous materials.

8

Title:

Hazardous Waste Worker Safety Training

Description:

Provides the dangerous waste worker with the fundamentals of safety when working with dangerous waste.

Note: This course fulfills training requirements of 29 CFR 1910.120 requiring dangerous waste training of workers at all treatment, storage, and/or disposal facilities regulated under RCRA.

13 Target Audience: Dangerous material and waste workers

I4 Technique:

Classroom and on-the-job training

15 Evaluation:

Written test

16 Length:

24 hours

17 Frequency:

Not applicable 

$1 \quad$ Title: Hazardous Waste Worker Safety Training Refresher
2 Description: Provides the dangerous waste worker with a refresher in the fundamentals of safety when working with dzigerous waste.
Note: This course fulfills training requirements of 29 CFR 1910.120 requiring dangerous wast? training of workers at all treatment, storage, and/or disposal facilities regulated under RCRA.
4 Target Audience:
5 Technique:
Classroom
6 Evaluation:
Written test
7 Length:
8 hours
8 Frequency:
12 months

\section{9}

10

11

Title:

Hazardous Material/Waste job-Specific Training

12

Description:

Provides job-specific dangerous material/waste information. Two checklists may be obtained from safety training to help the supervisor/manager through this session with each employee.

is

Note: Not a classroom presentation--supervisor conducts this exercise with each employee using the checklists.

14 Target Audience: Employees who complete generator hazards safety training

Technique:

On-the-job training

Evaluation:

On-the-job training checklist

17 Length:

Average - 2 hours

Frequency:

12 months 
Title:

2 Description:
Scott SKA-PAK MSA PAPR

This class is designed to instruct employees in the proper use of the Scott "SKAPAK" for entry, exit or work in conditions immediately dangerous to 1 ife and health and to instruct employees to recognize and handle emergencies. This class also includes instructions in the use of MSA, Inc. Powered Air Purifying Respirator (PAPR).

3 Target Audience:

General, Safety, QA, OPS/OPRS, Management, Maintenance Engineering

4 Technique: Classroom

5 Evaluation:

Practical exam

6 Length:

Approximately 2 hours

7 Frequency:

12 months

Title:

Self-Contained Breathing Apparatus (SCBA) Annual Qualification

11 Description:

Provides instructions in the proper use of a pressure-demand respirator in which breathing air is supplied from a cylinder carried on the user's back. The SCBA are typically used for emergency response situations in an atmosphere that is immediately dangerous to life or health.

12 Target Audience: General, Safety, OPS/OPRS, Maintenance

13 Technique:

Taught in a classroom using a slide projector and overhead

14 Evaluation: Written and practical test

15 Length: Approximately 4 hours

16 Frequency: 12 months 
$1 \quad$ Title:

2 Description:
Radiation Safety Training

A practical dress/undress demonstration is also required. Instructs radiation workers in the fundamentals of radiation protection and the proper procedures for monitoring exposures (ALARA). Training includes knowledge of the acute and chronic effects of exposure to radiation risks associated with occupational radiation exposure, mode of exposure, protective measures, instrumentation, monitoring programs, contamination control, personnel decontamination, warning signs and alarms, and responsibilities of employees and managers.

3 Target Audience: Radiation workers as defined in WHC-CM-4-10

4 Technique:

Taught in a classroom using a white board, appropriate audio/visual equipment

5 Evaluation:

Written exam and practical dress/undress

6 Length:

Approximately 7 hours

7 Frequency:

24 months (Retraining under Course Number 020003)

Description:

On-the-job training session under the supervision of an experienced person before full responsibilities may be assumed. In addition, all personnel on the hazardous waste site are required to have reviewed this Waste Sampling and Analysis Plan.

12 Target Audience: Nuclear Operators and Operations Management checklist

40 hours

12 months 
Title: $\quad$ Cardiopulmonary Resuscitation (CPR)

2 Description: Provide cardiopulmonary resuscitation training to the American Heart Association standards.

3 Target Audience: All employees

4 Technique: Classroom and active participation

5 Evaluation: Practical exam and written test

6 Length: 4 hours

$7 \quad 24$ months (recertification)

10 Title:

Noise Control (Noise-Hearing Conservation)

11 Description:

Provide employees with information conducive to hearing conservation. Supervisors and employees responsibility, exposure limits, hearing conservation requirements, protection devices, diagnosis of noise, induced hearing 1oss.

12 Target Audience: All employees exposed to an 8 hour time weighted average sound level of $85 \mathrm{dBA}$ or greater.

13 Technique: Classroom

14 Evaluation: None

15 Length: Approximately 1 hour

16 Frequency: 12 months

17 
1 Title:

Hazardous Waste Site Supervisor/Manager Safety Management Training

2. Description:

This program provides an additional eight hours of training for supervisors and managers covering hazardous waste programs.

3 Target Audience: Personnel who manage or have safety overview responsibilities of dangerous material and waste operations.

4 Technique: Classroom

5 Evaluation: None

6 Length: 8 hours

7 Frequency: Not applicable

8 
DOE/RL-90-04, Rev. 2

$12 / 15 / 93$

APPENDIX F

QUALITY ASSURANCE PROJECT PLAN FOR FACILITY AND SOIL SAMPLING

AT THE 303-K RADIOACTIVE MIXED-WASTE STORAGE FACILITY 
DOE/RL-90-04, Rev. 2

$12 / 15 / 93$

This page intentionally left blank. 


\section{CONTENTS}

GLOSSARY .......................... APP F-V

1.0 PROJECT DESCRIPTION . . . . . . . . . . . . . APP F-1

1.1 PROJECT OBJECTIVE ................ APP F-1

1.2 BACKGROUND INFORMATION ..................... FP F-1

1.3 QUALITY ASSURANCE PROJECT PLAN APPLICABILITY AND RELATIONSHIP TO THE WESTINGHOUSE HANFORD COMPANY QUALITY ASSURANCE PROGRAM ............. APP F-1

1.4 SAMPLING ACTIVITIES . . . . . . . . . . . . . APP F-1

2.0 PROJECT ORGANIZATION AND RESPONSIBILITIES . . . . . . . APP F-2

2.1 PROJECT MANAGEMENT RESPONSIBILITIES ........... APP F-2

2.2 ANALYTICAL LABORATORIES ............. APP F-4

2.3 OTHER SUPPORT CONTRACTORS ...................... APP F-4

3.0 OBJECTIVES FOR MEASUREMENTS . . . . . . . . . . . A APP F-4

4.0 SAMPLING PROCEDURES . . . . . . . . . . . APP F-6

4.1 PROCEDURE APPROVALS AND CONTROL .......... APP F-6

4.1.1 Westinghouse Hanford Procedures ......... APP F-6

4.1.2 Participant Contractor/Subcontractor

Procedures . . . . . APP F-6

4.2 SAMPLING AND INVESTIGATIVE PROCEDURES $\ldots \ldots \ldots$ APP F-7

4.3 PROCEDURE ADDITIONS AND CHANGES .................. APP F-7

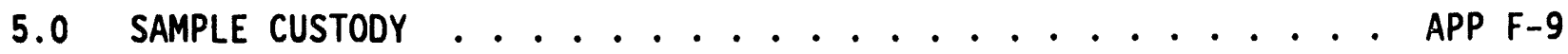

6.0 CALIBRATION PROCEDURES ....................... APP F-9

7.0 ANALYTICAL PROCEDURES ........................ APP F-9

8.0 DATA REDUCTION, VALIDATION, AND REPORTING ........ APP F-10

8.1 DATA REDUCTION AND DATA PACKAGE PREPARATION . . . . . . APP F-10

8.2 VALIDATION .......................... APP F-11

8.3 FINAL REVIEW AND RECORDS MANAGEMENT CONSIDERATIONS ... APP F-12

9.0 INTERNAL QUALITY CONTROL . . . . . . . . . . APP F-12

10.0 PERFORMANCE AND SYSTEM AUdITS . . . . . . . . . . APP F-14

11.0 PReVEnTIVE MaINTENANCE . . . . . . . . . . . . APP F-14

12.0 DATA ASSESSMENT PROCEDURES . . . . . . . . . . APP F-15

13.0 CORRECTIVE ACTION .......................... FP F-15

14.0 QUALITY ASSURANCE REPORTS . . . . . . . . . . APP F-15

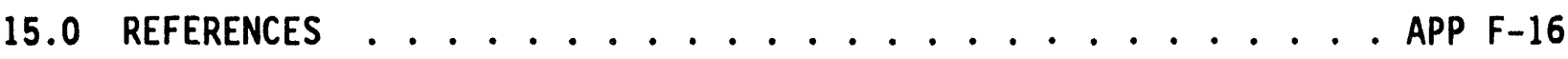


DOE/RL-90-04, Rev. 2

$12 / 15 / 93$

\section{FIGURE}

F-1 Project Organization and Facility and Soil Sampling at the 303-K Radioactive Mixed-Waste Storage Facility . . . . . . . APP F-3

\section{TABLES}

F-1 Analytes of Interest and Analytical Methods for the 303-K Facility Sampling . . . . . . . . . . . . APP F-5

F-2 Investigative Procedures for the 303-K Facility Sampling . . . APP F-8 


\section{GLOSSARY}

Accuracy: For the purposes of closure activities, accuracy may be interpreted as the measure of the bias in a system. Sampling accuracy is normally assessed through the evaluation of matrix spiked samples and reference samples.

Audit: For the purposes of closure activities, audits are considered to be systematic checks to verify the quality of operation of one or more elements of the total measurement system. In this sense, audits may be of two types:

(1) performance audits, in which quantitative data are independently obtained for comparison with data routinely obtained in a measurement system, or (2) system audits, involving a qualitative onsite evaluation of laboratories or other organizational elements of the measurement system for compliance with established quality assurance program and procedure requirements. For closure activities at the Hanford Site, performance audit requirements are fulfilled by periodic submittal of blind samples to the primary laboratory, or the analysis of split samples by an independent laboratory. System audit requirements are implemeited through the use of standard surveillance procedures.

Blind Sample: A blind sample refers to any type of sample routed to the primary laboratory, for purposes of auditing performance, relative to a pariticular sample matrix and analytical method. Blind samples are not specifically identified as such to the laboratory; they may be made from traceable standards, or may consist of sample material spiked with a known concentration of a known compound. See the glossary entry for audit.

Comparability: For the purposes of closure activities, comparability is an expression of the relative confidence with which one data set may be compared with another.

Completeness: For the purposes of closure activities, completeness may be interpreted as a qualitative parameter expressing the percentage of measurements judged to be valid.

Deviation: For the purpose of closure activities, deviation refers to a planned departure from established criteria that may be required as a result of unforeseen field situations or that may be required to correct ambiguities in procedures that may arise in practical applications.

Equipment Blanks: Equipment blanks consist of pure deionized, distilled water washed through decontaminated sampling equipment and placed in containers identical to those used for actual field samples; they are used to verify the adequacy of sampling equipment decontamination procedures, and are collected once each day.

Field Blanks: Field blanks consist of pure deionized, distilled water, transferred to a sample container at the site and preserved with the reagent specified for the analytes of interest; they are used to check for possible contamination originating with the reagent or the sampling environment, and are normally collected once each day. 
1 Field Duplicate Sample: Field duplicate samples are samples retrieved from the same sampling location using the same equipment and sampling technique, placed in separate identically prepared and preserved containers, and analyzed independently. Field duplicate samples are generally used to verify the repeatability or reproduceability of analytical data, and are normally analyzed with each analytical batch or every 20 samples, whichever is greater.

Matrix Spiked Samples: Matrix spiked samples are a type of laboratory quality control sample; they are prepared by splitting a sample received from the field into two homogenous aliquots (i.e., repicate samples), and adding a known quantity of a representative analyte of interest to one aliquot in order to calculate percentage of recovery.

Nonconformance: A nonconformance is a deficiency in characteristic, documentation, or procedure that renders the quality of material, equipment, services, or activities unacceptable or indeterminate. When the deficiency is of a minor nature, does not effect a permanent or significant change in quality if it is not corrected, and can be brought into conformance with immediate corrective action, it shall not be categorized as a nonconformance. However, if the nature of the condition is such that it cannot be immediately and satisfactorily corrected, it shall be documented in compliance with approved procedures and brought to the attention of management for disposition and appropriate corrective action.

Precision: Precision is a measure of the repeatability or reproducibility of specific measurements under a given set of conditions. Specifically, it is a quantitative measure of the variability of a group of measurements compared to their average value. Precision is normally expressed in terms of standard deviation, but may be also expressed as the coefficient of variation (i.e., relative standard deviation) and range (i.e., maximum value minus minimum value). Precision is assessed by means of duplicate/replicate sample analysis.

Quality Assurance: For the purposes of closure activities, quality assurance (QA) refers to the total integrated quality planning, quality control, quality assessment, and corrective action activities that collectively ensure that the data from monitoring and analysis meets all end user requirements and/or the intended end use of the data.

Quality Assurance Project Plan: The Quality Assurance Project Plan (QAPP) is an orderly assembly of management policies, project objectives, methods, and procedures that defines how data of known quality will be produced for a particular project or investigation.

Quality Control: For the purposes of closure activities, quality control (QC) refers to the routine application of procedures and defined methods to the performance of sampling, measurement, and analytical processes.

Reference Samples: Reference samples are a type of laboratory quality control sample prepared from an independent, traceable standard at a concentration other than that used for analytical equipment calibration, but within the calibration range. Such reference samples are required for every analytical batch or every 20 samples, whichever is greater. 
Replicate Sample: Replicate samples are two aliquots removed from the same sample container in the laboratory and analyzed independently.

Representativeness: For the purposes of closure activities, representativeness may be interpreted as the degree to which data accurately and precisely represent a characteristic of a population parameter, variations at a sampling point, or an environmental condition. Representativeness is a qualitative parameter which is most concerned with the proper design of a sampling program.

Split Sample: A split sample is produced through homogenizing a field sample and separating the sample material into two equal aliquots. Field split samples are usually routed to separate laboratories for independent analysis, generally for purposes of auditing the performance of the primary laboratory relative to a particular sample matrix and analytical method. See the glossary entry for audit. In the laboratory, samples are generally split to create matrix spiked samples; see the glossary entry above.

Trip Blanks: Trip blanks are a type of field quality control sample, consisting of pure deionized, distilled water in a clean, sealed sample container, accompanying each batch of containers shipped to the sampling site and returned unopened to the laboratory. Trip blanks are used to identify any possible contamination originating from container preparation methods, shipment, handling, storage, or site conditions.

Validation: For the purposes of closure activities, validation refers to a systematic process of reviewing a body of data against a set of criteria to provide assurance that the data are acceptable for their intended use. Validation methods may include review of verification activities, editing, screening, cross-checking, or technical review.

Verification: For the purposes of closure activities, verification refers to the process of determining whether procedures, processes, data, or documentation conform to specified requirements. Verification activities may include inspections, audits, surveillances, or technical review. 
This page intentionally left blank. 
DOE/RL-90-04, Rev. 2

$12 / 15 / 93$

\subsection{PROJECT DESCRIPTION}

\subsection{PROJECT OBJECTIVE}

The primary purpose of the waste sampling and analysis activities at the 303-K Radioactive Mixed-Waste Storage Facility (303-K Facility) is to evaluate contamination above action levels, if any, within the building, the outside storage pads, and in the near-surface soils associated with the facility.

\subsection{BACKGROUND INFORMATION}

The location of the 303-K Facility and general background information are provided in the 303-K Facility. Closure Plan.

\subsection{QUALITY ASSURANCE PROJECT PLAN APPLICABILITY AND RELATIONSHIP TO THE WESTINGHOUSE HANFORD CONPANY QUALITY ASSURANCE PROGRAM}

This QAPP applies specifically to the field sampling activities and laboratory analyses performed as part of the closure activities for the 303-K Facility at the Hanford Site. It is designed to be implemented in conjunction with the specific requirements of the 303-K Facility Closure Plan. The QAPP is prepared in compliance with the Environmental Engineering, Technology, and Permitting Function Quality Assurance Program Plan (WHC 1990). This plan describes the means selected to implement the QA program requirements defined by the Westinghouse Hanford Company Quality Assurance Manual [(WHC-CM-4-2) (WHC 1991a)], as applicable to environmental investigations, while accommodating the specific requirements for project plan format and content agreed upon in the Hanford Federal Facility Agreement and Consent Order (Ecology et al. 1990). Based on the data quality objectives, this QAPP will comply with EPA guidance documents for QA/QC and sampling and analysis activities as they apply to this Closure Plan (Ecology et al. 1990, Section 6.5). The program plan contains a matrix of procedural resources [from WHC-CM-4-2 and from the Westinghouse Hanford Environmenta] Investigations and Site Characterization Manual (WHC-CM-7-7) (WHC 1991b)] that have been drawn upon to support this QAPP. This QAPP is subject to mandatory review and revision before use on subsequent phases of the investigation. Distribution and revision control of this plan shall be in compliance with procedures QR 6.0, "Document Control," and QI 6.1, "Qual ity Assurance Document Control," all from WHC-CM-4-2 (WHC 1991a). Al1 plans and procedures referenced in the QAPP are available for regulatory review on request by the direction of the Technical Lead.

\subsection{SAMPLING ACTIVITIES}

Field sampling activities will include concrete and asphalt core or chip sampling and soil sampling. A complete description of all activities is provided in Chapter 7.0 of the 303-K Facility Closure Plan. 


\subsection{PROJECT ORGANIZATION AND RESPONSIBILITIES}

\subsection{PROJECT MANAGEMENT RESPONSIBILITIES}

The Environmental Engineering and Geotechnology Function of Westinghouse Hanford Company (Westinghouse Hanford) has primary responsibilities for conducting the sampling and analysis for the 303-K Facility closure activities. An organizational chart is included as Figure F-1. Responsibilities of key test personnel and organizations are described below:

- Closure Plan Lead (Regulatory Assessment, Permitting and NEPA Function). The Closure Plan Lead is responsible for project organization and interface with the regulatory agencies and the U.S. Department of Energy (DOE).

- Technical Lead. The Technical Lead will be responsible for direction of sampling and testing activities; responsibilities include the planning and authorization of all work and management of any subcontracted activities, as well as overall technical schedule, and budgetary performance.

- Quality Control Coordinator/Quality Assurance Officer. The quality control coordinator is responsible for coordinating and/or overseeing performance to the QAPP requirements by means of internal auditing and surveillance techniques. The Quality Assurance officer retains the necessary organizational independence and authority to identify conditions adverse to quality and to inform the technical lead of needed corrective action.

- Health and Safety Officer (Environmental Division/Environmental Field Services). The Health and Safety Officer is responsible for determining potential health and safety hazards from radioactive, volatile, and/or toxic compounds during sample handling and sampling decontamination activities and has the responsibility and authority to halt field activities caused by unacceptable health and safety hazards.

- Field Team Leader. The field team leader is responsible for onsite direction of sampling technicians in compliance with the requirements of the closure plan, this QAPP, and all implementing environmental investigation instructions (EII).

- Office of Sample Management. The Westinghouse Hanford Office of Sampling Management (OSM) is responsible for coordinating sample shipments between the field team and the analytical laboratory, resolution of any chain-of-custody issues, and for validation of all analytical data as discussed in Chapter 8.0 of this QAPP. 
DOE/RL-90-04, Rev. 2

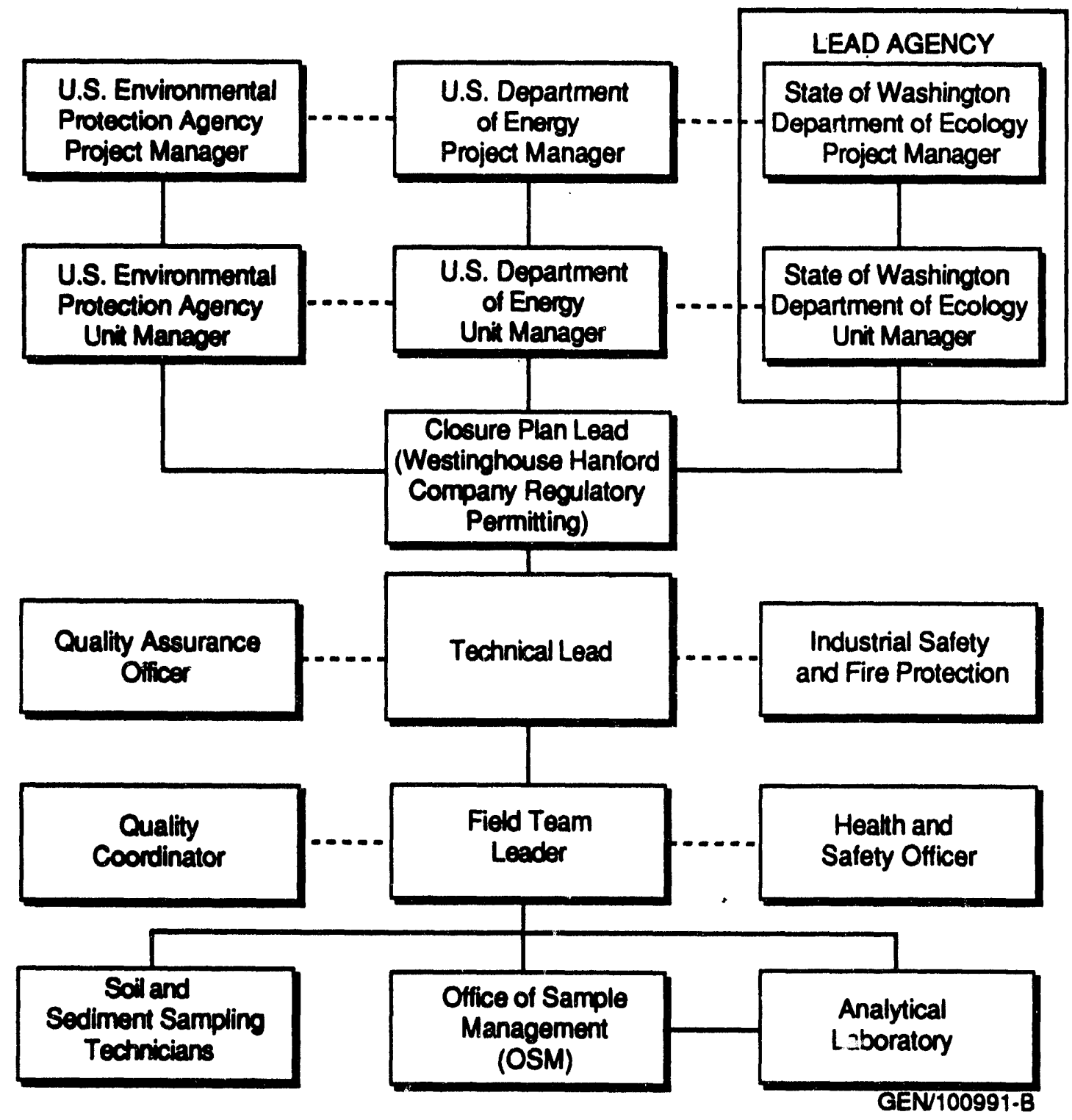

Figure F-1. Project Organization and Facility and Soil Sampling at the 303-K Radioactive Mixed-Waste Storage Facility. 


\subsection{ANALYTICAL LABORATORIES}

Soil samples shall be routed to an approved Westinghouse Hanford participant contrictor laboratory, or subcontractor laboratory, which shall be responsible for performing the analyses identified in this plan in compliance with work order or contractual requirements and Westinghouse Hanford-approved procedures; see Section 4.1.2. At the Technical Lead's option, services of alternate qualified laboratories may be procured for the performance of split sample analyses for performance audit purposes. If such an option is selected, the $Q A$ plan and applicable analytical procedures from the alternate laboratory also shall be approved by Westinghouse Hanford before their use in compliance with Section 4.1 .2 requirements. All analytical laboratory work shall be subject to the surveillance controls invoked by QI 7.3, "Source Surveillance and Inspection" (WHC 1991a).

\subsection{OTHER SUPPORT CONTRACTORS}

Procurement of other support contractors may be assigned project responsibilities at the direction of the Technical Lead. Such services shall be in compliance with standard Westinghouse Hanford procurement procedure requirements as discussed in Sections 4.1.2. All work shall be performed in compliance with Westinghouse Hanford-approved $Q A$ plans and/or procedures, subject to controls of QI 7.3, "Source Surveillance and Inspection" (WHC 1991a).

\subsection{OBJECTIVES FOR MEASUREMENTS}

The purpose of this investigation is to assess the potential contamination on the building walls, floor, ceiling, outside storage pads, and in associated soils. Analytical parameters for sample analys is are defined within Chapter 7.0 of the 303-K Facility Closure Plan, and are contained within the master list of analytical parameters provided by Table F-1.

As noted in Section 4.6 of Data Quality Objectives for Remedial Response Activities: Volume I, Development Process (EPA 1987), universal goals for precision, accuracy, representativeness, completeness, and comparability cannot be practicaliy established at the outset of an investigation. However, data are available from previously negotiated analytical contracts for Hanford Site investigations, the Data Quality objectives guidance document (EPA 1987), and from typical capabilities currently expected for laboratories involved in environmental analyses, that may be used as minimum guidelines for the selection of analytical methods appropriate for this investigation. Table F-1 provides preliminary target values for detection limits, precision, and accuracy that are intended for use in initial procurement negotiations with the analytical laboratory that will routinely perform chemical analyses for this investigation. After an individual laboratory statement of work is negotiated, and procedures are developed and approved as noted in Section 4.1, Table F-1 and this section shall be revised to reference approved detection limit, precision, and accuracy criteria as project requirements. 
Table F-1. Analytes of Interest and Analytjcal Methods for the 303-K Facility Sampling ${ }^{\text {,d }}$.

Analytical

Analyte of interest

Stenderd
reference
mothod

Minimum

Precisionc Accuracyc

\begin{tabular}{ll}
\hline Inorganics & Arsenic \\
Barium & Beryllium \\
Cacmium & Chlorides \\
Chromium & Lead \\
Mercury & Nickel \\
Nitrates \\
Nitrites \\
Silver \\
Uranium
\end{tabular}

$7061^{\circ}$
$6010^{\circ}$
$6010^{\circ}$
$6010^{\circ}$
EPA 300.8
$6010^{\circ}$
$7421^{\circ}$
$7470^{\circ}$
$6010^{\circ}$
EPA 300.0
EPA 300.8
$6010^{\circ}$
SCINTREX
limit

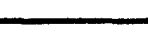

\begin{tabular}{|c|c|}
\hline $\begin{array}{ll} \pm 25 \% & \text { RPD } \\
\pm 25 \% & \text { RPD } \\
\pm 25 \% & \text { RPD } \\
\pm 25 \% & \text { RP } \\
\pm 25 \% & \text { RPD } \\
\pm 25 \% & \text { RPD } \\
\pm 25 \% & \text { RPD } \\
\pm 25 \% & \text { RPD } \\
\pm 25 \% & \text { RPD } \\
\pm 25 \% & \text { RPD } \\
\pm 25 \% & \text { RPD } \\
\pm 25 \% & \text { RPD } \\
\pm 25 \% & \text { RPD } \\
\pm 25 \% & \text { RPD }\end{array}$ & $\begin{array}{l} \pm 25 \% \\
\pm 25 \% \\
\pm 25 \% \\
\pm 25 \% \\
\pm 25 \% \\
\pm 25 \% \\
\pm 25 \% \\
\pm 25 \% \\
\pm 25 \% \\
\pm 25 \% \\
\pm 25 \% \\
\pm 25 \% \\
\pm 25 \% \\
\pm 15 \%\end{array}$ \\
\hline
\end{tabular}

$\begin{array}{llll}8010^{\circ} & 13 \mathrm{ug} / \mathrm{kg} & \pm 25 \% \text { RPD } & \pm 25 \% \\ 8010^{\mathrm{a}} & 25 \mathrm{ug} / \mathrm{kg}, & \pm 25 \% \text { RPD } & \pm 25 \% \\ 8010^{\mathrm{a}} & 25 \mathrm{ug} / \mathrm{kg} & \pm 25 \% \text { RPD } & \pm 25 \% \\ 8010^{\mathrm{a}} & 25 \mathrm{ug} / \mathrm{kg} & \pm 25 \% \mathrm{RPD} & \pm 25 \% \\ 8010^{\mathrm{a}} & 13 \mathrm{ug} / \mathrm{kg} & & \\ 8010^{\mathrm{a}} & 13 \mathrm{ug} / \mathrm{kg} & \pm 25 \% \mathrm{RPO} & \pm 25 \% \\ 8010^{\mathrm{a}} & 25 \mathrm{ug} / \mathrm{kg} & & \\ 8010^{\mathrm{a}} & 25 \mathrm{ug} / \mathrm{kg} & \pm 25 \% \mathrm{RPO} & \pm 25 \%\end{array}$

\footnotetext{
Mothode spocified are from Iast Methods for Evaluating Sol id Haste (SW-846) (EPA 1986).

bnalytical methods shall be in compliance with approved Westinghouse Hanford or Westinghouse Henford-approved participent contractor or subcontractor procedures. All procecures. shall be reviewed and approved in compl iance with requirements specified in the West inghouse Hanford Qual ity Assurance Program Plan for Comprehensive Environmental Response, Compensation. and Liability Act of 1980 remedial investigation and feasibility study activities.

CMinim requirewents for method detection levels, precision, and accuracy will be methodspacific, and shall be negotiated and established in the procedure review and approval process. Target values are indicated there appropriate; precision is expressed in terms of relative percent different (RPD) and accuracy as percentage recovery.

d Analyses shall be performed by an approved participant contractor or subcontractor laboratory.

Detection limits are estimated instrumental detection limits. Detection limits represent detection limits in water. Limits for soils, sludges, oils, and other matrices will be greater.

"SCINTREX is a trademark of SCINTREX, Inc.
} 


\subsection{PROCEDURE APPROVALS AND CONTROL}

\subsubsection{Westinghouse Hanford Procedures}

The Westinghouse Hanford procedures that will be used to support the closure plan have been selected from the Quality Assurance Program Index included in the Environmental Engineering, Technology, and Permitting Function Quality Assurance Program Plan (WHC 1990). Selected procedures include EIIs from the Environmental Investigations and Site Characterization Manual (WHC 1991b), and Quality Requirements (QR) and Quality Instructions (QI), from the Westinghouse Hanford Quality Assurance Manual (WHC 1991a). Procedure approval, revision, and distribution control requirements applicable to EIIs are addressed in EII 1.2, "Preparation and Revision of Environmental Investigations Instructions" (WHC 1991b); requirements applicable to QIs and QRs are addressed in QR 5.0, "Instructions, Procedures, and Drawings"; QI 5.1, "Preparation of Quality Assurance Documents"; QR 6.0, "Document Control"; and QI 6.1, "Quality Assurance Document Control" (WHC 1991a). Other procedures applicable to the preparation, review, approval, and revision of OSM and other Hanford Site analytical laboratory procedures shall be as defined in the various procedures and manuals identified in Environmental Engineering, Technology, and Permitting Function Quality Assurance Program Plan (WHC 1990) under criteria 5.00 and 6.00 . All procedures are available for regulatory review. Procedures not currently included in the EII manual (concrete coring procedures) will be prepared before initiation of sampling.

\subsubsection{Participant Contractor/Subcontractor Procedures}

As noted in Section 2.1, participant contractor and/or subcontractor services may be procured at the direction of the Technical Lead. All such procurement shall be subject 20 the applicable requirements of $Q R 4.0$, "Procurement Document Control"; QI 4.1, "Procure"'ent Document Control"; 
QI 4.2, "External Services Control"; QR 7.0, "Control of Purchased Items and Services"; QI 7.1, "Procurement Planning and Control"; and/or QI 7.2, "Supplier Evaluation" (WHC 1991a). Whenever such services require procedural controls, requirements for use of Westinghouse Hanford procedures, or for submittai of contractor procedures for Westinghouse Hanford review and approval before use, shall be included in the procurement document or work order, as applicable. In addition to the submittal of analytical procedures, analytical laboratories shall be required to submit the current version of their internal QA program plans. All analytical laboratory plans and procedures shall be reviewed and approved before use by qualified personnel from the OSM, Westinghouse Hanford analytical laboratories organizations, or other qualified personnel, as directed by the Technical Lead. All reviewers shall be qualified under the requirements of EII 1.7, "Indoctrination, Training, and Qualification" (WHC 1991b). All participant contractor or subcontractor procedures, plans, and/or manuals shall be retained as project quality records in compliance with EII 1.6, "Records Management" (WHC 1991b); QR 17.0, "Quality Assurance Records"; and QI 17.1, "Qual ity Assurance Records Control" (WHC 1991a). All such documents are available for regulatory review on request.

\subsection{SAMPLING AND INVESTIGATIVE PROCEDURES}

Soil sampling activities shall be performed in compliance with EII 5.2, "Soil and Sediment Sampling" (WHC 1991b). Soil samples shall routinely be routed to offsite analytical laboratories for chemical analyses. Additional EIIs that have been selected to support the test activity are identified in Table F-2. Presently, EIIs have not been developed for concrete core or chip sampling. Sample identification requirements and container type, preparation, and preservation requirements shall be as specified in EII 5.2. All sampling equipment decontamination shall be in compliance with EII 5.5, "1706 KE Laboratory Decontamination of RCRA/CERCLA Sampling Equipment"

(WHC 1991b).

\subsection{PROCEDURE ADDITIONS AND CHANGES}

Additional EIIs or EII updates that may be required, as a consequence of the 303-K Facility Closure Plan requirements, shall be developed in compliance with EII 1.2, "Preparation and Revision of Environmental Investigations Instructions" (WHC 1991b). Should deviations from established EIIs be required to accommodate unforseen field situations, they may be authorized by the Field Team Leader in accordance with the requirements of EII 1.4, "Deviation from Environmental Investigations Instructions" (WHC 1991b). Documentation, review, and disposition of instruction change authorization forms are defined within EII 1.4. Other types of document change requests shall be completed as required by the Westinghouse Hanford procedures governing their preparation and revision. 
Tab?e F-2. Investigative Procedures for the 303-K Facility Sampling.

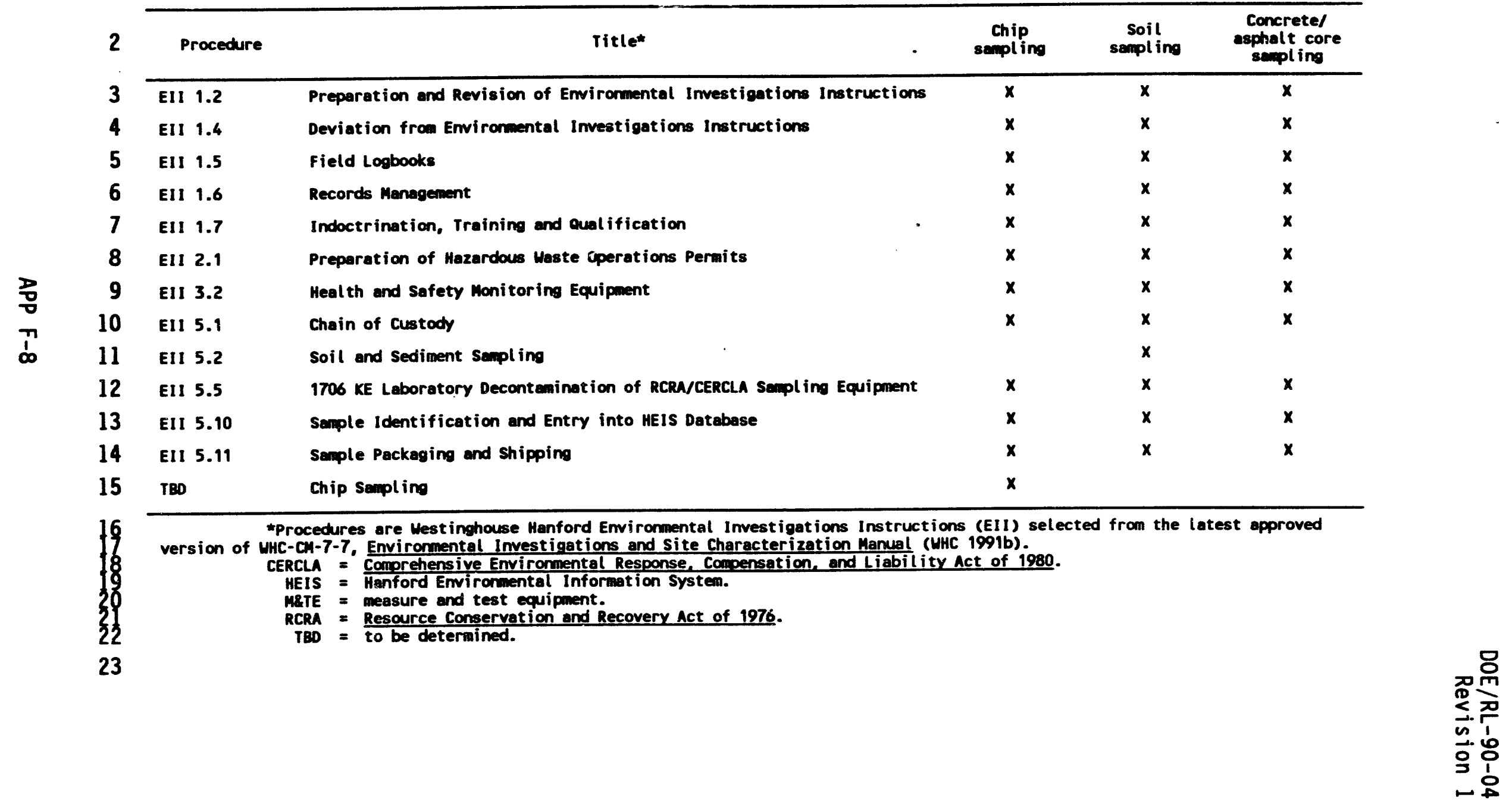




\subsection{SAMPLE CUSTODY}

All samples obtained during the implementation of the sampling and analysis plan shall be controlled as required by EII 5.1 "Chain of Custody," (WHC 1991b) from the point of origin to the analytical laboratory. Laboratory chain-of-custody procedures shall be reviewed and approved as required by Westinghouse Hanford procurement control procedures as noted in Section 4.1, and shall ensure the maintenance of sample integrity and identification throughout the analytical process. At the direction of the Technical Lead, requirements for return of residual sample materials after completion of analysis shall be defined in accordance with those procedures defined in the procurement documentation to s. bcontractor or participant contractor laboratories. Chain-of-custody forms shall be initiated for returned residual samples as required by the approved procedures applicable within the participating laboratory. Results of analyses shall be traceable to original samples through the unique code or identifier specified in Section 4.0. All results of analyses shall be controlled as permanent project quality records as required by QR 17.0, "Quality Assurance Records" (WHC 1991a) and EII 1.6, "Records Management" (WHC 1991b).

\subsection{CALIBRATION PROCEDURES}

Calibration of all Westinghouse Hanford measuring and test equipment, whether in existing inventory or newly purchased, shall be controlled as required by QR 12.0, "Control of Measuring and Test Equipment"; QI 12.1, "Acquisition and Calibration of Portable Measuring and Test Equipment" (WHC 1991a); QI 12.2, "Measuring and Test Equipment Calibration by User" (WHC 1991a); and/or EII 3.2, "Health and Safety Monitoring Equipment" (WHC 1991b). Routine operational checks for Westinghouse Hanford field equipment shall be as defined within applicable EIIs or procedures; similar information shall be provided in Westinghouse Hanford-approved participant contractor or subcontractor procedures.

Calibration of Westinghouse Hanford, participant contractor, or subcontractor laboratory analytical equipment shall be as defined by applicable standard analytical methods, subject to Westinghouse Hanford review and approval.

\subsection{ANALYTICAL PROCEDURES}

Analytical methods or procedures based on the reference methods identified in Table F-1 and Chapter 3.0 of this QAPP, shall be selected or developed and approved before use in compliance with appropriate Westinghouse Hanford procedure and/or procurement control requirements, as noted in Section 4.1. 


\subsection{DATA REDUCTION, VALIDATION, AND REPORTING}

\subsection{DATA REDUCTION AND DATA PACKAGE PREPARATION}

All analytical laboratories shall be responsible for preparing a report summarizing the results of analysis and for preparing a detailed data package that includes all information necessary to perform data validation to the extent indicated by the minimum requirements of Section 8.2. Data summary report format and data package content shall be defined in procurement documentation subject to Westinghouse Hanford review and approval as noted in Section 4.1. At a minimum, laboratory data packages shall include the following.

- Sample receipt and tracking documentation, including identification of the organization and individuals performing the analysis, the names and signatures of the responsible analysts, sample holding time requirements, references to applicable chain of custody procedures, and the dates of sample receipt, extraction, and analysis.

- Instrument calibration documentation, including equipment type and model, with continuing calibration data for the time period in which the analysis was performed.

- Quality control data, as appropriate for the methods used, including matrix spike/matrix spike duplicate data, recovery percentages, precision data, 1aboratory blank data, and identification of any nonconformances that may have affected the laboratory's measurement system during the time period in which the analysis was performed.

- The analytical results or data deliverables, including reduced data, reduction formulas or algorithms, and identification of data outliers or deficiencies.

Other supporting information, such as initial calibration data, reconstructed ion chromatographs, spectrograms, traffic reports, and raw data, need not be included in the submittal of individual data packages unless specifically requested by the Technical Lead or the OSM. However, all sample data shall be retained by the analytical laboratory and made available for systems or program audit purposes upon request by Westinghouse Hanford, U.S. Department of Energy, Richland Field Office (DOE-RL), or regulatory agency representatives; see Chapter 10.0 of this QAPP. Such data shall be retained by the analytical laboratory through the duration of their contractual statement of work, at which point it shall be turned over to Westinghouse Hanford for archiving.

The completed data package shall be reviewed and approved by the analytical laboratory's QA Manager before submittal to OSM for validation as discussed in Section 8.2. The requirements of this section shall be included in procurement documentation or work orders, as appropriate, in compliance with the standard Westinghouse Hanford procurement control procedures referenced in Section 4.1. 


\subsection{VALIDATION}

Validation of the completed data package shal! be performed by qualified Westinghouse Hanford OSM personnel. Validation requirements will be defined within approved OSM data validation procedures, but at a minimum will include the requirements as defined within this section.

For organic analyses, validation reports shall be prepared documenting checks of the following areas as recommended in Laboratory Data Validation Functional Guidelines for Evaluating Organics Analyses (EPA 1988a):

- Data summàry narrative

- Sample holding times

- Gas chromatograph/mass spectrometer tuning and mass calibration requirements

- Continuing calibration requirements

- Method blank sample requirements

- Surrogate recovery requirements

- Matrix spike'matrix spike duplicate requirements

- Internal standards performance requirements

- Target compound identification requirements

- Target compound quantitation requirements and reported detection limits

- Any tentatively identified compounds, library search, assessment, and quantitation requirements

- Data assessment requirements.

For inorganic analyses, validation reports shall be prepared documenting checks of the following areas, as recommended in Laboratory Data Validation Functional Guidelines for Evaluating Inorganics Analyses (EPA 1988b):

- Data summary narrative

- Sample holding times

- Continuing calibration requirements

- Method blank sample requirements

- Interference check sample requirements

- Laboratory control sample requirements 
- Duplicate sample analysis

- Matrix spike sample requirements

- Atomic absorption quality control requirements

- Inductively coupled plasma serial dilution requirements

- Overall data assessment requirements.

\subsection{FINAL REVIEW AND RECORDS MANAGEMENT CONSIDERATIONS}

All validation reports and supporting analytical data packages shall be subjected to a final technical review by qualified reviewers at the direction of the Westinghouse Hanford Technical Lead, before submittal to regulatory agencies or inclusion in reports or technical memoranda. All validation reports, data packages, and review comments shall be retained as permanent project quality records in compliance with EII 1.6, "Records Management" (WHC 1991b) and QA 17.0, "Quality Assurance Records" (WHC 1991a). A11 technical data will be entered into the appropriate database in compliance with EII 1.11, "Technical Data Management" (WHC 1991b).

\subsection{INTERRAL QUALITY CONTROL}

All analytical samples shall be subject to in-process quality control measures in both the field and laboratory. Unless superseded by specific directions provided in Chapter 7.0 of the 303-K Facility Closure Plan, the following minimum field quality control requirements apply. These requirements are adapted from Test Methods for Evaluating Solid Wastes, SW-846 (EPA 1986), as modified by the proposed rule changes included in the Federal Register, Volume 54, No. 13 (EPA 1989). Definitions of the sample type can be found in the glossary.

- Field duplicate samples. Field duplicate samples are generally used to verify the repeatability or reproduceability of analytical data. For each shift of sampling activity under an individual sampling subtask, a minimum of 5 percent of the total collected samples shall be duplicated.

- Split samples. At the Technical Lead's direction, field or field duplicate samples may be split in the field and sent to an al ternative laboratory as a performance audit of the primary laboratory.

- Blind samples. At the Technical Lead's direction, blind reference samples may be introduced into any sampling round as a performance and audit of the primary laboratory. Blind sample type shall be as directed by the Technical Lead. 
- Field blanks. Field blanks are used to check for possible contamination originating with the reagent or the sampling environment, and are normally collected once each day. Field blanks consist of pure deionized, distilled water that is transferred to a sample container at the site and preserved with the reagent specified for the analyses of interest.

- Equipment blanks. Equipment blanks are used to verify the adequacy of sampling equipment decontamination procedures, and are collected once each day.

- Trip blanks. Trip blanks shall be returned unopened to the laboratory, and are prepared as a check on possible contamination originating from container preparation methods, shipment, handling, storage, or site conditions. In compliance with standard West inghouse Hanford procurement procedures, requirements for trip blank preparation shall be included in procurement documents of work orders to the sample container supplier and/or preparer. Trip blanks shall be collected daily.

The internal QC checks performed by analytical laboratories for the laboratory analyses shall meet the following minimum requirements:

- Matrix spiked and matrix spiked duplicate samples. Matrix spiked and matrix spiked duplicate samples require the addition of a known quantity of a representative analyte of interest to the sample as a measure of recovery percentage. The spike should be made in a replicate of one of the field duplicate samples. Spike compound selection, quantities, and concentrations shall be described in the laboratory's analytical procedures. One sample shall be spiked per analytical batch, or once every 20 samples whichever is greater.

- Quality control reference samples. A QC reference sample shall be prepared from an independent standard at a concentration other than that used for calibration, but within the calibration range.

Reference samples are required as an independent check on analytical technique and methodology, and shall be run with every analytical batch, or every 20 samples, whichever is greater.

Other requirements specific to laboratory analytical equipment calibration are included in Chapter 6.0 of this QAPP. The minimum requirements of this section shall be invoked in procurement documents or work orders, compliant with standard Westinghouse Hanford procedures as noted in Section 4.1. 


\subsection{PREVENTIVE MAINTENANCE}

All measurement and testing equipment used in the field and laboratory that directly affects the quality of the analytical data shall be subject to preventive maintenance measures that ensure minimization of measurement system downtime. Field equipment maintenance instructions shall be as defined by the approved procedures governing their use. Laboratories shall be responsible for performing or managing the maintenance of their analytical equipment; maintenance requirements, spare parts lists, and instructions shall be included in individual methods or in laboratory $Q A$ plans, subject to Westinghouse Hanford review and approval. When samples are analyzed using EPA reference methods, the requirements for preventive maintenance of laboratory analytical equipment as defined by the reference method shall apply. 


\subsection{DATA ASSESSMENT PROCEDURES}

Test data from this investigation will be assessed as required by Chapter 7.0 of the 303-K Facility Closure Plan. Analytical data shall first be compiled and summarized by the laboratory and validated in compliance with approved $O S M$ procedures meeting all minimum requirements of Chapter 8.0 of this QAPP.

\subsection{CORRECTIVE ACTION}

Corrective action requests required as a result of surveillance reports, nonconformance reports, or audit activity shall be documented and dispositioned as required by QR 16.0, "Corrective Action;" QI 16.1, "Trending/Trend Analysis; " and QI 16.2, Corrective Action Reporting," (WHC 1991a). Primary responsibilities for corrective action resolution are assigned to the Technical Lead and the QA Coordinator. Other measurement systems, procedures, or plan corrections that may be required because routine review processes shall be resolved as required by governing procedures or shall be referred to the Technical Lead for resolution. Copies of all surveillance, nonconformance, audit, and corrective action documentation shall be routed to the project $Q A$ records upon completion or closure.

\subsection{QUALITY ASSURANCE REPORTS}

As previously stated in Chapters 10.0 and 13.0 of this QAPP, project activities shall be regularly assessed by auditing and surveillance processes. Surveillance, nonconformance, audit, and corrective action documentation shali be routed to the project quality records upon completion or closure of the activity. A report summarizing all audit, surveillance, and instruction change authorization activity (see Section 4.4), as well as any associated corrective actions, shall be prepared by the $Q A$ Coordinator at the completion of the activity or annually beginning 1 year after approval of the closure plan, whichever is sooner. The report(s) shall be submitted to the Technical Lead for incorporation into the final report prepared at the end of the investigation. The final report shall include an assessment of the overall adequacy of the total measurement system with regard to the data quality objectives of the investigation. 


\subsection{REFERENCES}

Ecology, et al., 1990, Hanford Federal Facility Agreement and Consent Order, Vol. 1 and 2, Washington State Department of Ecology, U.S. Environmental Protection Agency, and U.S. Department of Energy, Richland, Washington.

EPA, 1986, Test Methods for Evaluating Solid Wastes, SW-846, Third edition, U.S. Environmental Protection Agency/Office of Solid Waste and Emergency Response, Washington, Washington, D.C.

EPA, 1987, Data Quálity Objectives for Remedial Response Activities:

Volume I, Development Process, EPA/540/6-87/003, Office of Emergency and Remedial Response and Office of Waste Programs Enforcement, U.S. Environmental Protection Agency, Washington, D.C.

EPA, 1988a, Laboratory Data Validation Functional Guidelines for Evaluating Organics Analyses, Hazardous Site Evaluation Division, U.S. Environmental Protection Agency, Washington, D.C.

EPA, 1988b, Laboratory Data Validation Functional Guidelines for Evaluating Inorganics Analyses, Hazardous Site Evaluation Division,

U.S. Environmental Protection Agency, Washington, D.C.

EPA, 1989, "Hazardous Waste Management System; Testing and Monitoring Activities (Proposed Rule)"; in Federal Register, Vol. 54, No. 13, pp 3212-3228.

WHC, 1990, Environmental Engineering, Technology and Permitting Function Quality Assurance Program Plan, WHC-EP-0383, Westinghouse Hanford Company, Richland, Washington.

WHC, 1991a, Westinghouse Hanford Company Quality Assurance Manual, WHC-CM-4-2, Westinghouse Hanford Company, Richland, Washington.

WHC, 1991b, Environmental Investigations and Site Characterization Manual, WHC-CM-7-7, Westinghouse Hanford Company, Richland, Washington. 
DISTRIBUTION

Number of Copies

OFFSITE

6

Washington State Department of Ecology

S. E. McKinney (4)

Lacey

D. Nylander (2)

Kennewick

2

U. S. Environmental Protection Agency

D. L. Duncan (2) Seattle

ONSITE

8

U. S. Department of Energy-

Richland Operations office

R. M. Carisino . A4-52

R. N. Krekel A5-15

O. M. Holgado T7-09

J. E. Rasmussen A5-15

GSSC A4-35

DOE Public Reading Room H2-53

DOE Record File

Administrative Record H6-08

17 Westinghouse Hanford Company

J. G. Adler (3)

J. A. Remaize (2)

F. A. Ruck

J. M. Steffen

H6-23

L6-18

H6-23

E. A. Weakley

N1-47

B. D. Williamson

L6-26

J. L. Wright

Document Processing and

B3-15

L6-26

Distribution (2)

L8-15

Central Files

L8-04

Document Clearance Administration

H4-17

EPIC (2)

RCRA Files/GHL

H6-08

H6-23

Pacific Northwest Laboratory

Technical Files

$\mathrm{K} 1-11$ 


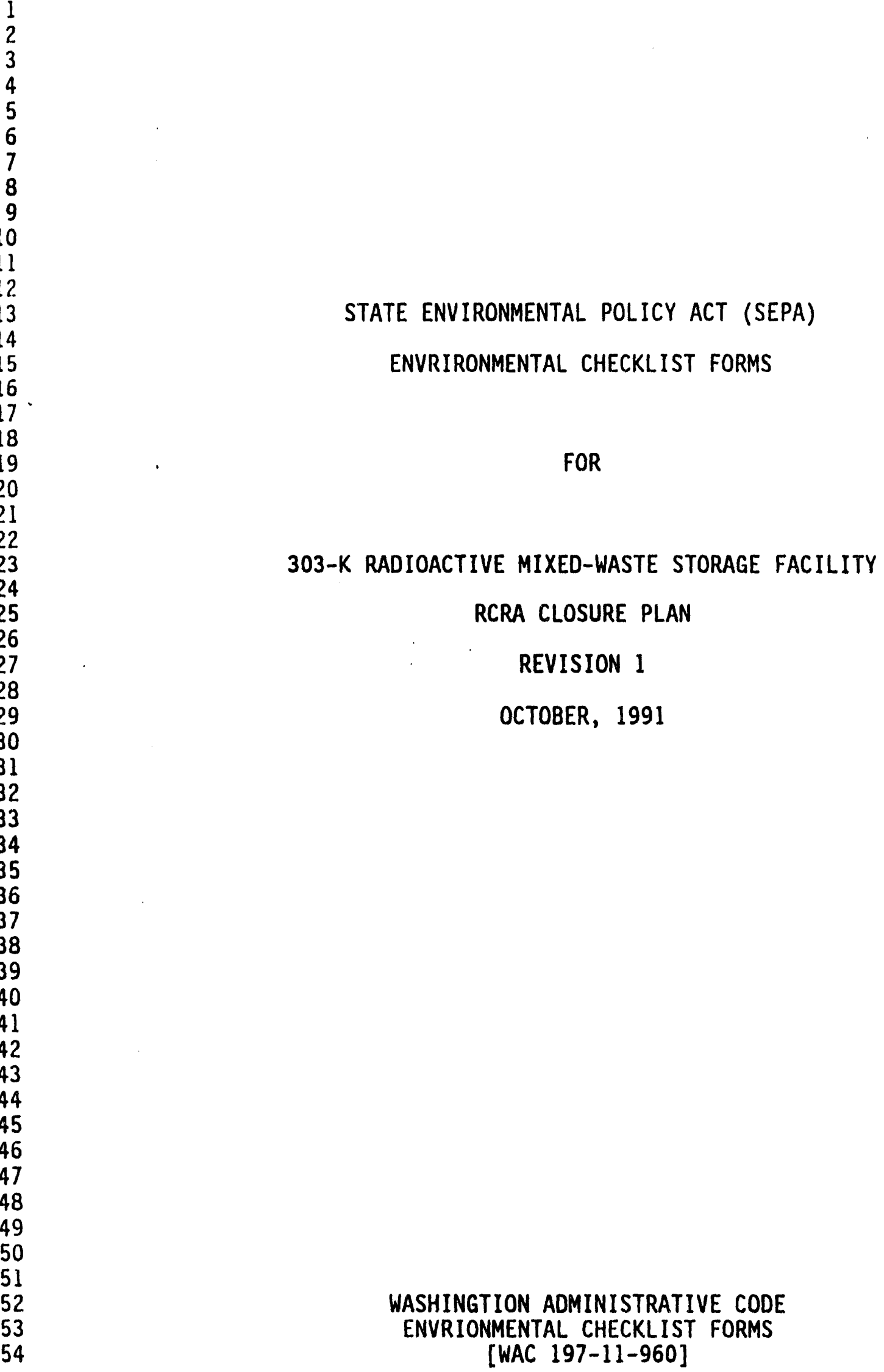




\section{A. BACKGROUND}

1. Name of proposed project, if applicable:

RCRA Closure of the 303-K Radioactive Mixed-Waste Storage Facility.

Information contained in this State Environmental Policy Act (SEPA)

Checklist pertains only to the portion of the Hanford Site 300 Area wich contains the 303-K Radioactive Mixed-Waste Storage Facility.

2. Name of applicants:

U.S. Department of Energy, Richland Operations Office (DOE-RL); and Westinghouse Hanford Company (WHC)

3. Address and phone number of applicants and contact persons:

U.S. Department of Energy

Field Office, Richland

P.0. Box 550

Richland, Washington 99352

Contact Persons:

R. D. Izatt, Program Manager

Office of Environmental Assurance, Permits and Policy

(509) 376-5441

4. Date checklist prepared:

October 14, 1991

5. Agency requesting checklist:

State of Washington

Department of Ecology

Mail Stop PV-11

O1ympia, Washington 98504-8711

6. Proposed timing or schedule (including phasing, if applicable):

A closure plan (DOE/RL-90-04 Revision 1) is being submitted for the closure of the 303-K Radioactive Mixed-Waste Storage Facility. The schedule for closure has not been determined at this time.

Closure of the facility will begin upon notification by The State of Washington Department of Ecology, (Ecology) and by the United States Environmental Protection Agency, (EPA) of approval of the closure plan. The closure activities will be completed in accordance with the closure plan in approximately 52 weeks after approval of the plan by Ecology and the EPA. 
SEPA Checklist $303-K$ RM-WSF

Page 2 of 14

7. Do you have any plans for future additions, expansion, or further activity related to or connected with this proposal?

It is intended that the facility will be clean closed in accordance with the closure plan. Once the facility is clean closed, it will be used as a less-than-90 day storage facility for storage of radioactive mixedwaste. If clean closure is not practical, final disposition of the site : 111 be determined through the Remedial Investigation and Feasibility Study (RI/FS) process in conjunction with the 300 Area Operabie Units, 300-FF-3 and 300-FF-5, under the Comprehensive Environmental Response, Compensation and Liability Act of 1980, (CERCLA) and the Hanford Federal Facility Agreement and Consent Order.

8. List any environmental information you know about that has been prepared, or will be prepared, directly related to this proposal.

A revised RCRA Part A Permit Application for the facility was submitted to Ecology and EPA on November 17, 1987.

This SEPA Checklist is being submitted to the Washington State Department of Ecology (Ecology) concurrently with the RCRA Closure Plan (DOE/RL-9004 Revision 1) for the 303-K Radioactive Mixed-Waste Storage Facility. A RI/FS and National Environmental Policy Act (NEPA) documentation are planned for the 300-FF-3 Operable Unit.

ERDA-1538 contains environmental information on radioactive waste operations at the Hanford Site, including the 300 Area.

9. Do you know whether applications are pending for government approvals of other proposals directly affecting property covered by your proposal? If yes, explain.

No applications are known to be pending.

10. List any government approvals or permits that will be needed for your proposal, if known.

Ecology and the EPA must approve the closure $p 1$ an for the $303-K$ Radioactive Mixed-Waste Storage Facility. No other permits are known to be required at. this time.

11. Give brief, complete description of your proposal, including the proposed uses and the size of the project and site. There are several questions later in this checklist that ask you to describe certain aspects of your proposal. You do not need to repeat those answers on this page.

The 303-K Radioactive Mixed-Waste Storage Facility will be closed as a dangerous waste storage facility regulated under WAC 173-303. Clean closure of the 303-K Building and associated waste storage pads is proposed for final closure. Once the facility is clean closed, it will be used as a less-than-90 day storage facility for storage of radioactive mixed-waste. 
SEPA Checklist

$303-K$ RM-WSF

Page 3 of 14

The site consists of a cinder-block building and fenced outside storage pads of concrete, asphalt and gravel covering an area of approximately 620 square meters. Only the north half of the building is included within the storage area and is separated from the south half by a cinder-block wal1. The site also contains a process sewer system.

Following removal of any dangerous waste inventory, the building and the storage pads will be decontaminated to appropriate action levels with one or more of the following methods:

- Damp wipe downs

- Vacuum assisted mechanical removal

- Sandblasting

0 High-pressure steam and suction

The building, floor, outside storage pads, and underlying soils will be sampled to determine effectiveness of decontamination procedures and presence of contaminants. Decontamination will prcceed until acceptable action levels are reached. When these levels are achieved, clean closure will be complete.

If these action levels cannot be achieved, those portions of the building, floor, and pads that exceed action levels will be removed. If dangerous constituents are determined to exist in the soil above action levels, the soil will be remediated as part of the CERCLA RI/FS process for the 300-FF-3 operable unit. The process sewer system is scheduled to be addressed under the $300-F F-3$ operable unit RI/FS process and is not included in the closure plan.

Details of the proposed sampling and closure activities are found in the accompanying closure plan.

12. Location of the proposal. Give sufficient information for a person to understand the precise location of your proposed project, including a street address, if any, and section, township, and range, if known. If a proposal would occur over a range of area, provide the range or boundaries of the site(s). Provide a legal description, site plan, vicinity map, and topographic map, if reasonably available. While you should submit any plans required by the agency, you are not required to duplicate maps or detailed plans submitted with any permit applications related to this checklist.

The 303-K Radioactive Mixed-Waste Storaye Facility is located in the northwest portion of the Hanford Site 300 Area approximately one mile north of the City of Richland, Washington. The facility is located in Section 11, T $10 \mathrm{~N}, \mathrm{R} 28 \mathrm{E}$. A location map and site plans are included in the closure plan. 
SEPA Checklist

$303-K$ RM-WSF

Page 4 of 14

\section{B. ENVIRONMENTAL ELEMENTS}

1. Earth

a. General description of the site (circle one): Flat, rolling, hilly, steep slopes, mountainous, other

Flat.

b. What is the steepest slope on the site (approximate percent slope)?

The approximate slope of the land at the site of the $303-K$ RM-WSF is less than two percent.

c. What general types of soils are found on the site (for example, clay, sandy gravel, peat, muck)? If you know the classification of agricultural soils, specify them and note any prime farmland.

The soil at the site consists of compacted sand and gravel fill material underlain by sandy gravel with excellent drainage characteristics. No farming is permitted on the Hanford Site.

d. Are there surface indications or history of unstable soils in the immediate vicinity? If so, describe.

No.

e. Describe the purpose, type, and approximate quantities of any filling or grading proposed. Indicate source of fill.

No additional fill will be required.

f. Could erosion occur as a result of clearing, construction, or use? If so, generally describe.

Erosion is not expected.

g. About what percent of the site will be covered with impervious surfaces after project construction (for example, asphalt or buildings)?

Approximately $80 \%$ of the surface is covered at the existing facility. No change will be made.

h. Proposed measures to reduce or control erosion, or other impacts to the earth, if any:

None. 
SEPA Checklist

$303-K$ RM-WSF

Page 5 of 14

2. Air

a. What types of emissions to the air would result from the proposal (i.e., dust, automobile, odors, industrial wood smoke) during construction and when the project is completed? If any, generally describe and give approximate quantities, if known.

Minor amounts of exhaust will be generated by vehicles used to gain access to the site. Small quantities of dust and vapors could be generated by decontamination and sampling activities.

b. Are there any off-site sources of emissions or odors that may affect your proposal? If so, generally describe.

No.

c. Proposed measures to reduce or control emissions or other impacts to the air, if any?

None at this time.

3. Water

a. Surface

1) Is there any surface water body on or in the immediate vicinity of the site (including year-round and seasonal streams, saltwater, lakes, ponds, wetlands)? If yes, describe type and provide names. If appropriate, state what stream or river it flows into.

No. The closest body of water is the Columbia River approximately one-half mile from the 303-K Radioactive MixedWaste Storage Facility.

2) Will the project require any work over, in, or adjacent to (within 200 feet) the described waters? If yes, please describe and attach available plans.

No.

3) Estimate the amount of fill and dredge material that would be placed in or removed from surface water or wetlands and indicate the area of the site that would be affected. Indicate the source of fill material.

None.

4) Will the proposal require surface water withdrawals or diversions? Give general description, purpose, and approximate quantities if known.

No. 
5) Does the proposal lie within a 100-year floodplain? If so, note location on the site plan.

No.

6) Does the proposal involve any discharges of waste materials to surface waters? If so, describe the type of waste and anticipated volume of discharge.

No.

b. Ground

1) Will ground water be withdrawn, or will water be discharged to ground water? Give general description, purpose, and approximate quantities if known.

Insignificant amounts of water will be discharged to the soil by steam cleaning and concrete coring activities.

2) Describe waste material that will be discharged into the ground from septic tanks or other sources, if any (for example: Domestic sewage; industrial, containing the following chemicals; agricultural....; etc.). Describe the general size of the system, the number of such systems, the number of houses to be served (if applicable), or the number of animals or humans the system(s) are expected to serve.

Does not apply.

c. Water Run-off (including storm water)

1) Describe the source of run-off (including storm water) and method of collection and disposal, if any (include quantities, if known). Where will this water flow? Will this water flow into other waters? If so, describe.

The Hanford Site receives 6 inches to 8 inches of annual precipitation. Any precipitation that occurs at the site will run off the building and pads and seep into the soil on and near the site. No run-off will enter surface waters.

2) Could waste materials enter ground or surface waters? If so, generally describe.

Slightly contaminated runoff from the pads could enter the soil during closure and reach the groundwater. The quantity would be very minor because of the dry climate and evapotranspiration from the soil. No materials will enter surface waters. 
d. Proposed measures to reduce or control surface, ground, and run-off water impacts, if any:

None are proposed at this time.

4. Plants

a. Check or circle types of vegetation found on the site.

deciduous tree: alder, maple, aspen, other evergreen tree: fir, cedar, pine, other shrubs

-

pasture

crop or grain

wet soil plants: cattail, buttercup, bulrush, skunk cabbage, other

water plants: water lily, eelgrass, milfoil, other

$\bar{x}$ other types of vegetation

Small amounts of forbes and grasses may be seasonally present.

b. What kind and amount of vegetation will be removed or altered?

Small amounts of forbes and grasses.

c. List threatened or endangered species known to be on or near the site.

None. Additional information on the Hanford Site environment can be found in the environmental document referred to in the answer to checklist question A.8.

d. Proposed landscaping, use of native plants, or other measures to preserve or enhance vegetation on the site, if any:

None at this time.

5. Animals

a. Circle any birds and animals which have been observed on or near the site or are known to be on or near the site:

birds: hawk, heron, eagle, songbirds, other mammals: deer, bear, elk, beaver, other

fish: bass, salmon, trout, herring, shellfish, other

Starlings, lagomorphs and pigeons have been observed on the site. Additional information on the Hanford Site environment can be found in the environmental document referenced in the answer to checklist question A.8. 
SEPA Checklist

$303-K$ RM-WSF

Page 8 of 14

b. List any threatened or endangered species known to be on or near the site.

The Bald Eagle and the White Pelican are sometimes seen on the Hanford Site and possibly may be seen near the 300 area.

The site of the 303-K Radioactive Mixed-Waste Storage Facility is not known to be used by any threatened or endangered species. However, additional information concerning endangered and threatened species on the Hanford Site can be found in the environmental document referred to in the answer to checklist question A.8.

c. Is the site part of a migration route? If so, explain.

No: however, the adjacent Columbia River is part of the broad Pacific Flyway for waterfowl migration and other birds also migrate along the river.

d. Proposed measures to preserve or enhance wildlife, if any: None at this time.

\section{Energy and Natural Resources}

a. What kinds of energy (electric, natural gas, oil, wood stove, solar) will be used to meet the completed project's energy needs? Describe whether it will be used for heating, manufacturing, etc.

Electricity for lighting.

Water for washdown.

Fuel for vehicles.

b. Would your project affect the potential use of solar energy by adjacent properties? If so, generally describe.

No.

c. What kinds of energy conservation features are included in the plans of this proposal? List other proposed measures to reduce or control energy impacts, if any:

None.

\section{Environmental Health}

a. Are there any environmental health hazards, including exposure to toxic chemicals, risk of fire and explosion, spill, or hazardous waste, that could occur as a result of this proposal? If so, describe.

The 303-K Facility will be clean closed by removing or decontaminating all dangerous waste and waste residues to appropriate action levels. All proper procedures will be followed 
SEPA Checklist

303-K RM-WSF

Page 9 of 14

during these operations to minimize exposure to hazardous waste.

The potential exists for exposure to hazardous waste during sampling of the building and storage pads. Procedures to prevent and manage hazards are presented in the closure plan.

1) Describe special emergency services that might be required.

Hanford Site security, fire response, and ambulance services are on call at all times in the event of an onsite emergency.

2) Proposed measures to reduce or control environmental health hazards, if any:

Environmental health hazards are expected to be minimal. Procedures to prevent and manage potential hazards are presented in the closure plan.

b. Noise

1) What type of noise exists in the area which may affect your project (for example: traffic, equipment, operation, other)?

None.

2) What types and levels of noise would be created by or associated with the project on a short-term or a long-term basis (for example: traffic, construction, operation, other)? Indicate what hours noise would come from the site.

Minor amounts of noise from traffic and equipment are expected on a short term basis during day shift hours.

3) Proposed measures to reduce or control noise impacts, if any:

Vehicles and equipment will meet manufacturer's requirements for noise suppression.

8. Land and Shorel ine Use

a. What is the current use of the site and adjacent properties?

The Hanford Site houses reactors, chemical separation systems, waste management facilities, and related facilities used for the production of special nuclear materials. Other scientific and engineering programs are carried out.

The 303-K Radioactive Mixed-Waste Storage Facility is currently used to store DOT-specification containers of radioactive and mixedwastes generated at other buildings in the 300 Area. Detailed descriptions of these wastes can be found in the closure plan. 
SEPA Checklist

$303-K$ RM-WSF

Page 10 of 14

b. Has the site been used for agriculture? If so, describe.

No portion of the Hanford Site, including the site $303-\mathrm{K}$ facility, has been used for agricultural purposes since 1943.

c. Describe any structures on the site.

The site, consists of a cinder-block building and outside storage pads consisting of two concrete pads, two asphalted areas, and a gravel area. The facility is surrounded by a fence.

The cinder-block building is divided into two sections by a cinderblock wall. The north half of the building was used for mixed waste storage and the closure plan applies to the north half only. The north end of the building is approximately $8.5 \mathrm{~m}$ by $8.5 \mathrm{~m}$ in floor plan and $3.5 \mathrm{~m}$ high.

d. Will any structures be demolished? If so, what?

If the facility cannot be clean closed, those portions of the building, floor, and pads that exceed action levels will be removed.

e. What is the current zoning classification of the site?

The Hanford Site is zoned by Benton County as an Unclassified Use (U) district.

f. What is the current comprehensive plan designation of the site?

The 1985 Benton County Comprehensive Land Use PIan designates the Hanford Site as the "Hanford Reservation." Under this designation, 1 and on the Site may be used for "activities nuclear in nature." Non-nuclear activities are authorized "if and when DOE approval for such activities is obtained."

g. If applicable, what is the current shoreline master program designation of the site?

Does not apply.

h. Has any part of the site been classified as an "environmentally sensitive" area? If so, specify.

No.

i. Approximately how many people would reside or work in the completed project?

No people will reside or have office space in the facility. A small number of personnel will be working intermittently at the facility if it is used for less than 90 day mixed waste storage. 
j. Approximately how many people would the completed project displace? None.

k. Proposed measures to avoid or reduce displacement impacts, if any: Does not apply.

1. Proposed measures to ensure the proposal is compatible with existing and projected land uses and plans, if any:

See answer to checklist question B.8.f.

9. Housing

a. Approximately how many units would be provided, if any? Indicate whether high, middle, or low-income housing. None.

b. Approximately how many units, if any, would be eliminated? Indicate whether high, middle, or low-income housing.

None.

c. Proposed measures to reduce or control housing impacts, if any: Does not apply.

10. Aesthetics

a. What is the tallest height of any proposed structure(s), not including antennas; what is the principal exterior bui.lding material(s) pruposed?

Existing building is approximately $3.5 \mathrm{~m}$ high and no change in exterior materials will be made.

b. What views in the immediate vicinity would be altered or obstructed? None.

c. Proposed measures to reduce or control aesthetic impacts, if any: None.

11. Light and Glare

a. What type of light or glare will the proposal produce? What time of day would it mainiy occur? None. 
b. Could light or glare from the finished project be a safety hazard or interfere with views?

No.

c. What existing off-site sources of light or glare may affect your proposal?

None.

d. Proposed measures to reduce or control light and glare impacts, if any:

Does not apply.

12. Recreation

a. What designated and informal recreational opportunities are in the immediate vicinity?

None.

b. Would the proposed project displace any existing recreational uses? If so, describe.

No.

c. Proposed measures to reduce or control impacts on recreation, including recreation opportunities to be provided by the project or applicant, if any?

Does not apply.

\section{Historic and Cultural Preservation}

a. Are there any places or objects listed on, or proposed for, national, state, or local preservation registers known to be on or next to the site? If so, generally describe.

No places or objects listed on, or proposed for, national, state, or local preservation registers are known to be on or next to the site. Additional information on the Hanford Site environment can be found in the environmental document referred to in the answer to checklist question $\mathrm{A} .8$.

b. Generally describe any landmarks or evidence of historic, archaeological, scientific, or cultural importance known to be on or next to the site.

There are no known archaeological, historical, or Native American religious sites on or next to the facility. Additional information on the Hanford Site environment can be found in the environmental document referenced in the answer to Checklist question A.8. 
c. Proposed measures to reduce or control impacts, if any:

Does not apply.

\section{Transportation}

a. Identify public streets and highways serving the site, and describe proposed access to the existing street system. Show on site plans, if any.

Does not apply.

b. Is site currently served by public transit? If not, what is the approximate distance to the nearest transit stop?

The facility is not publicly accessible and, therefore, is not served by public transit.

c. How many parking spaces would the completed project have? How many would the project eliminate?

None.

d. Will the proposal require any new roads or streets, or improvements to existing roads or streets, not including driveways? If so, generally describe (indicate whether public or private).

No.

e. Will the project use (or occur in the immediate vicinity of) water, rail, or air transportation? If so, generally describe.

No.

f. How many vehicular trips per day would be generated by the completed project? If known, indicate when peak volumes would occur.

Intermittent vehicular traffic will be required if the facility is used as a less than 90 day storage facility.

g. Proposed measures to reduce or control transportation impacts, if any:

None.

\section{Public Services}

a. Would the project result in an increased need for public seryices (for example: fire protection, police protection, health care, schools, other)? If so, generally describe.

No. 
SEPA Checklist

303-K RM-WSF

Page 14 of 14

b. Proposed measures to reduce or control direct impacts on public services, if any:

Does not apply.

16. Utilities

a. Circle utilities currently available at the site: electricity, natural gas, water, refuse service, telephone, sanitary sewer, septic system, other:

Electricity and water.

b. Describe the utilities that are proposed for the project, the utility providing the service, and the general construction activities on the site or in the immediate vicinity which might be needed.

No new utilities are required.

\section{SIGNATURES}

The above answers are true and complete to the best of my knowledge. We understand that the lead agency is relying on them to make its decision.
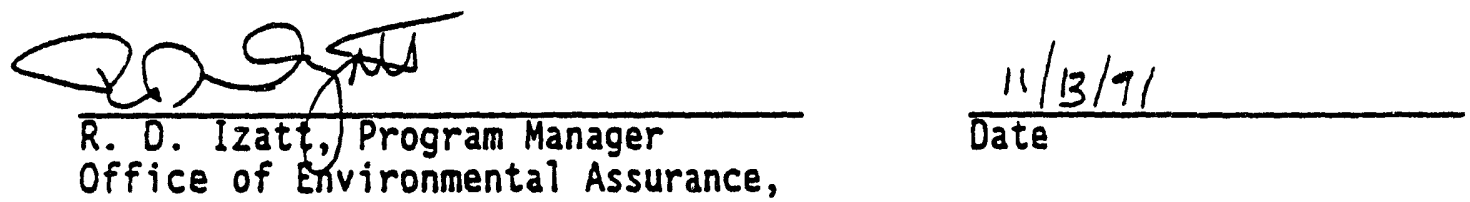

Permits and Policy

U.S. Department of Energy

Field Office, Richland

RE R-Lek

R. E. Lerch, Manager

Environmental Division

Westinghouse Hanford Company

$\frac{11-4-91}{\text { Date }}$



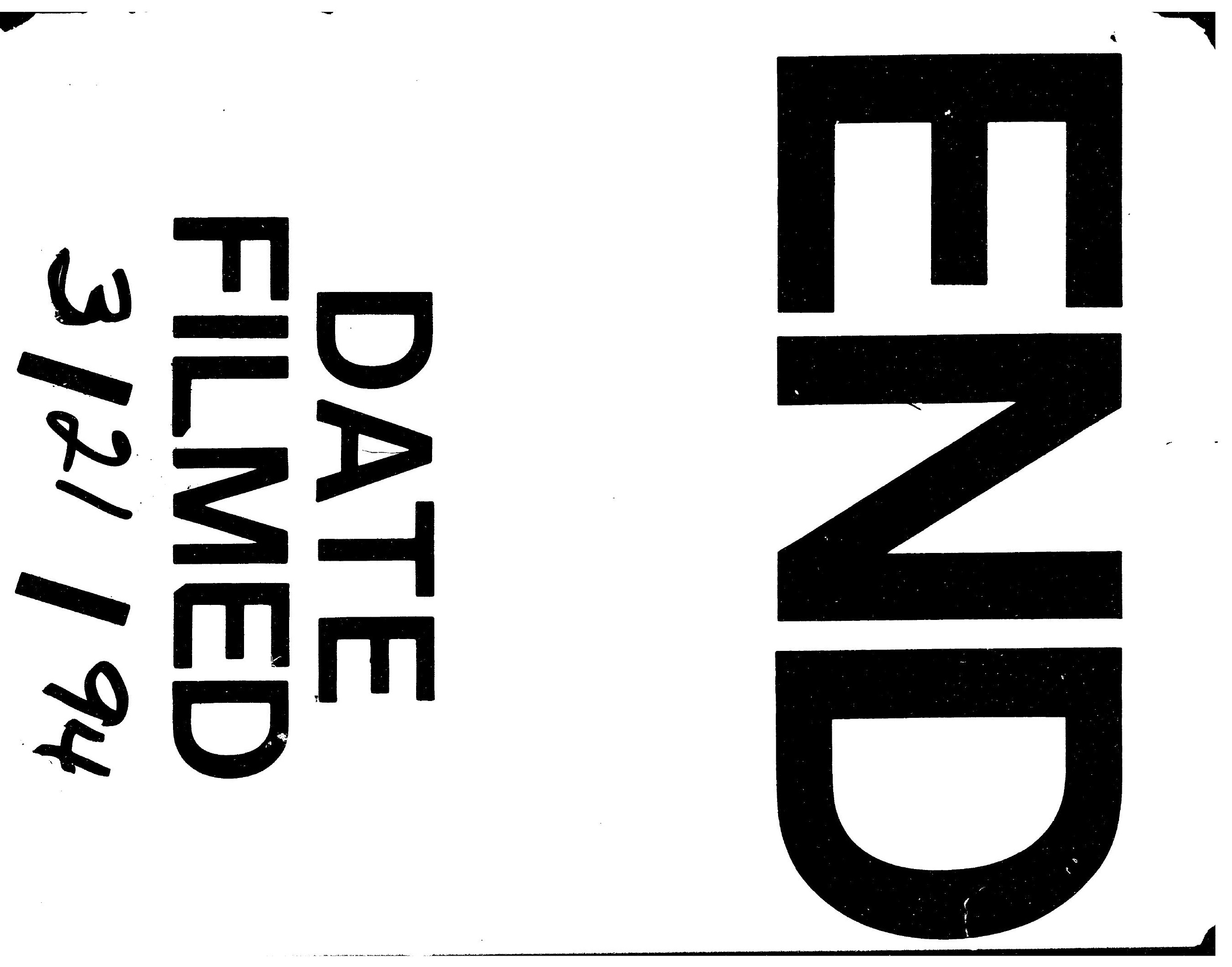
.

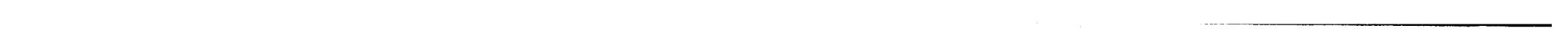
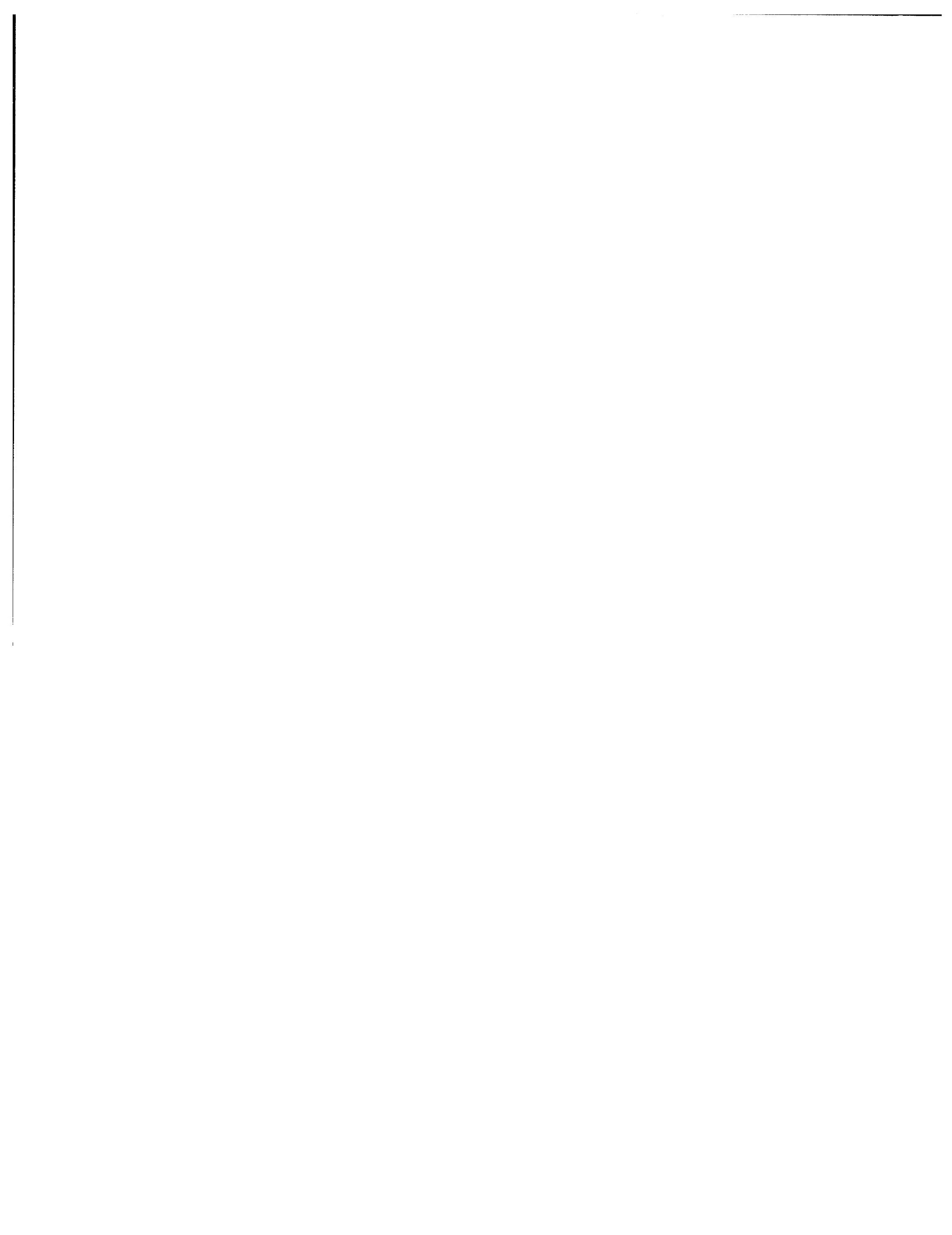